U.S. Department of the Interior U.S. Geological Survey

Water-Resources Investigations Report 98-4125:

Prepared in cooperation with $=$ Douglas County

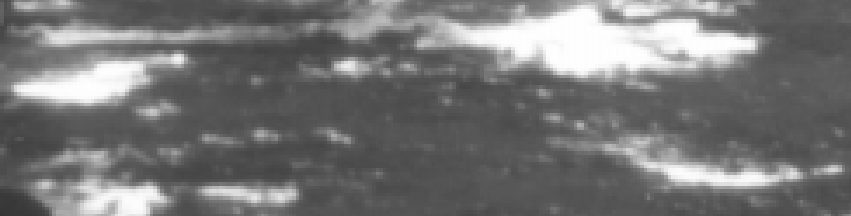

\title{
Water Quality and Algal Conditions in the North Umpqua River Basin, Oregon, 1992-95, and Implications for Resource Management
}




\section{Cover photograph:}

North Umpqua River above Copeland Creek and Old Man Rock, summer 1994.

(Photograph by Chauncey W. Anderson, U.S. Geological Survey.) 


\section{Water-Quality and Algal Conditions in the North Umpqua River Basin, Oregon, 1992-95, and Implications for Resource Management}

\section{By CHAUNCEY W. ANDERSON and KURT D. CARPENTER}

U.S. Department of the Interior

U.S. Geological Survey

Water-Resources Investigations Report 98-4125

Prepared in cooperation with

Douglas County 


\section{U.S. DEPARTMENT OF THE INTERIOR \\ BRUCE BABBITT, Secretary}

U.S. GEOLOGICAL SURVEY

Thomas J. Casadevall, Acting Director

The use of firm, trade, and brand names in this report is for identification purposes only and does not constitute endorsement by the U.S. Geological Survey.

For addtional information write to:

\section{District Chief}

U.S. Geological Survey, WRD

10615 S. E. Cherry Blossom Drive

Portland, Oregon 97216-3159

E-mail: info-or@usgs.gov
Copies of this report can be purchased from:

U.S. Geological Survey

Branch of Information Services

Box 25286

Federal Center

Denver, CO 80225 


\section{CONTENTS}

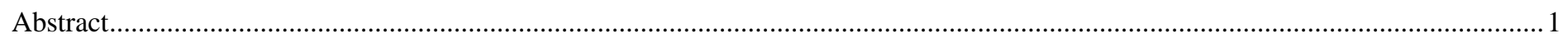

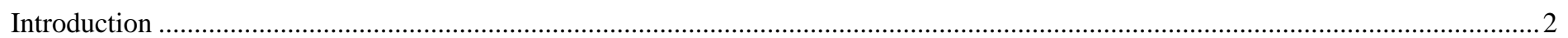

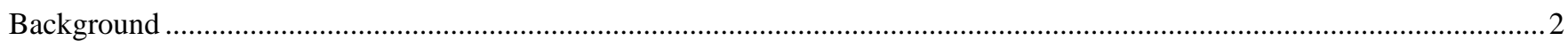

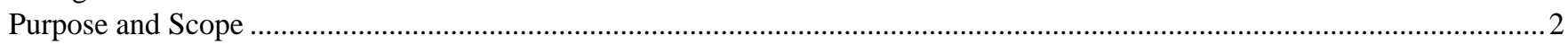

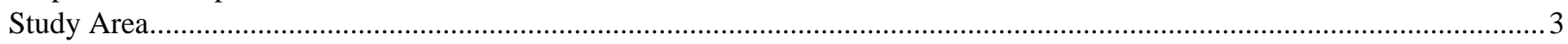

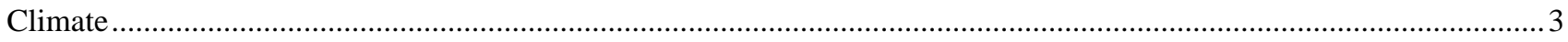

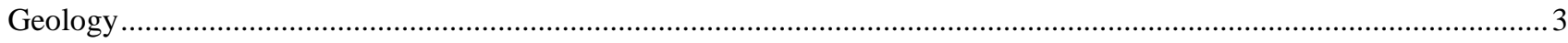

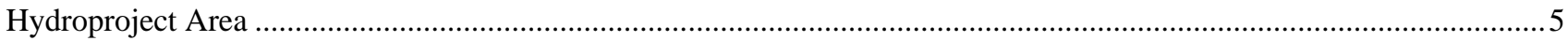

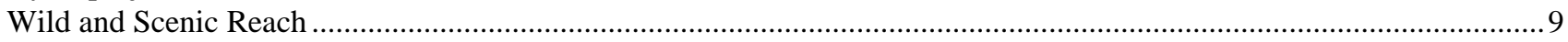

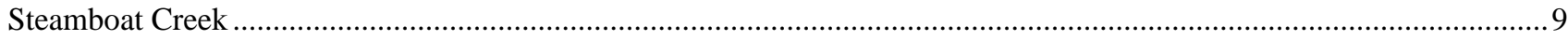

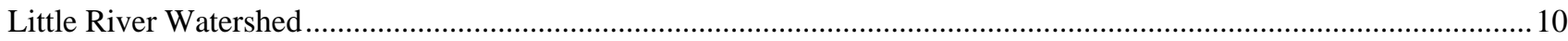

Water-Quality Issues and Aquatic Ecosystem Concepts ............................................................................................. 10

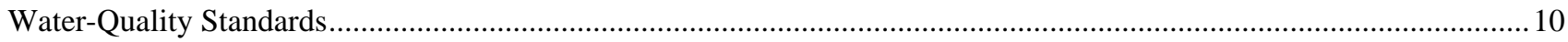

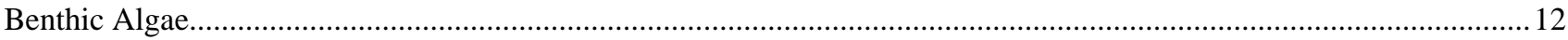

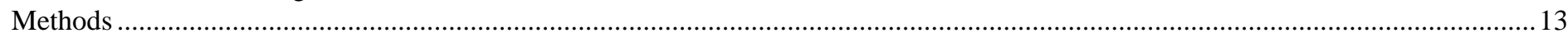

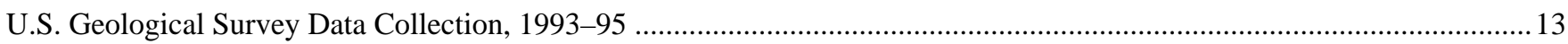

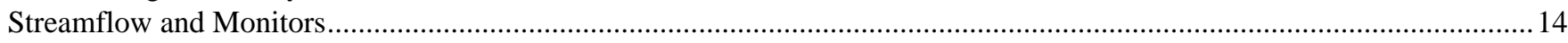

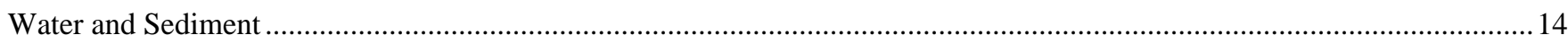

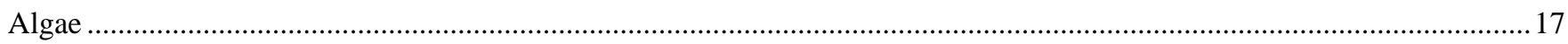

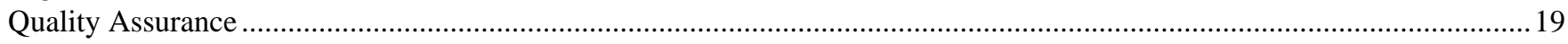

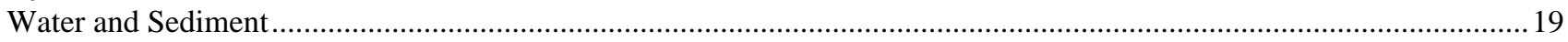

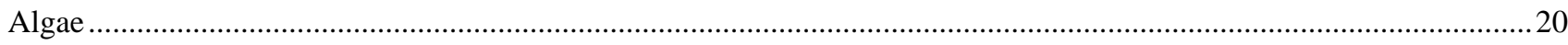

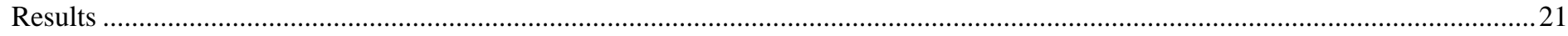

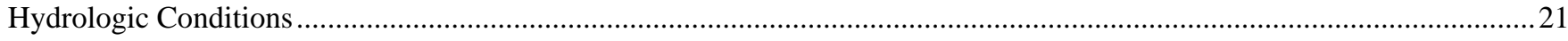

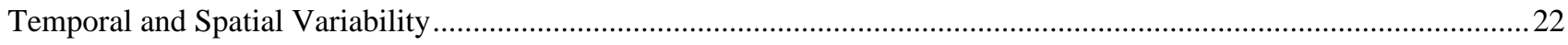

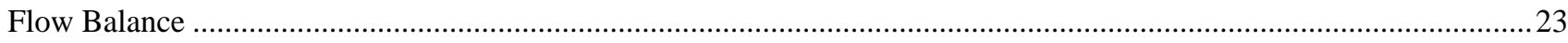

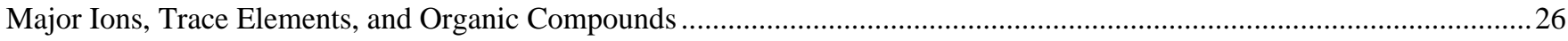

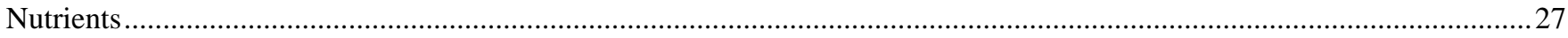

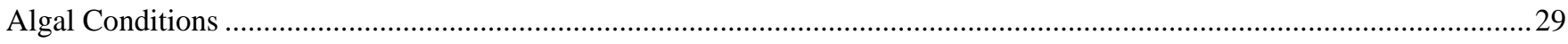

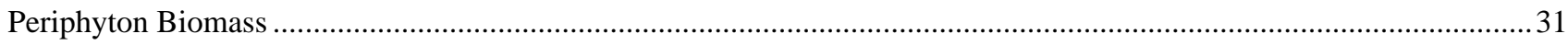

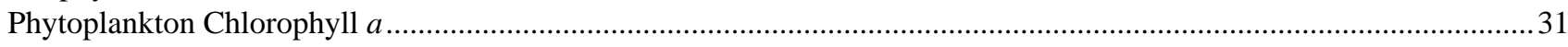

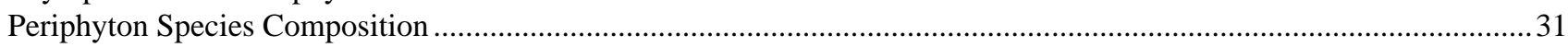

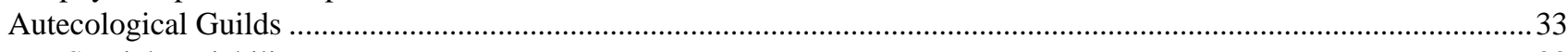

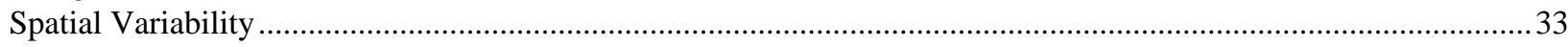

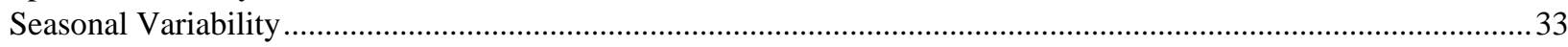

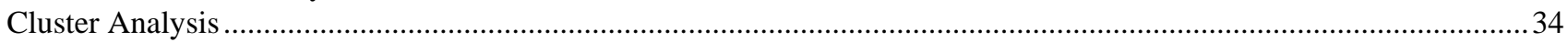

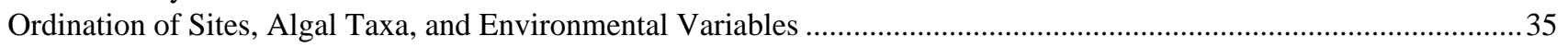

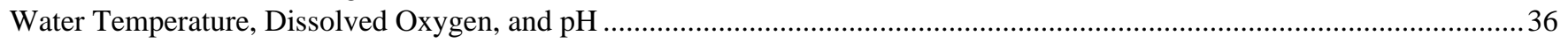

Relations of Water Quality and Algal Conditions to Resource Management .................................................................................... 40

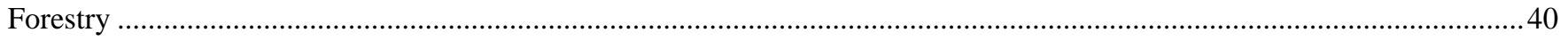

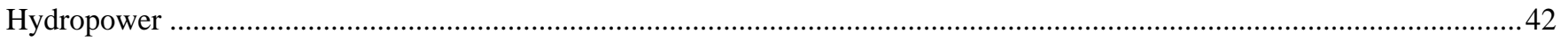

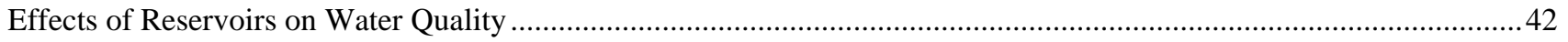

Effects of Reservoirs on Algal Abundance and Distribution.................................................................................. 44

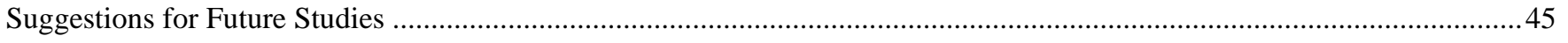

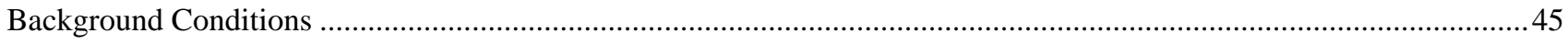

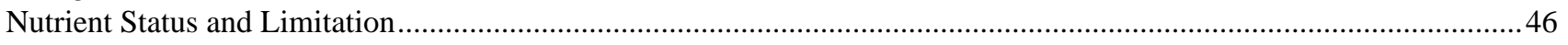

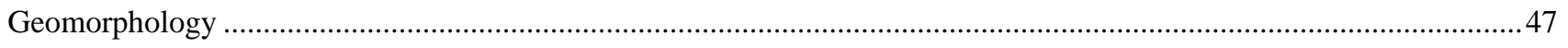

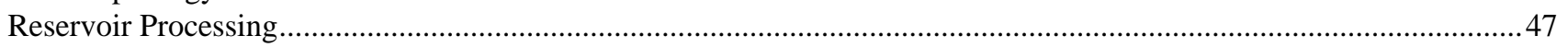

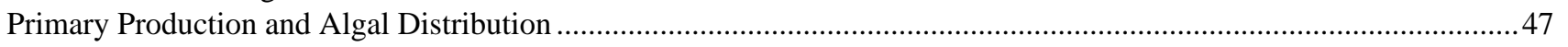

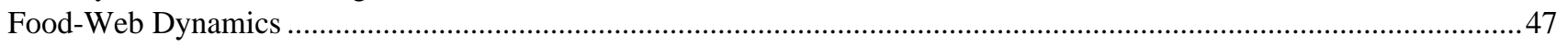

Summary

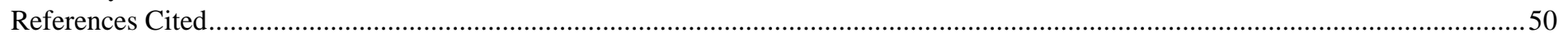


A. Water-quality data from the July 1995 synoptic sampling in the North Umpqua River Basin, Oregon ...................................59

B. Quality assurance/quality control data for water collected between 1993 and 1995 in the North Umpqua River Basin, Oregon......

C. Water-quality and bed-sediment data from 1993-94 samplings in the North Umpqua River Basin, Oregon ..........................64 64

D. Nutrient concentrations from sites in the North Umpqua River Basin, Oregon, sampled by PacifiCorp during July 1995 .......70

E. Algal data from 1994-95 samplings in the North Umpqua River Basin, Oregon ............................................................... 71

\section{PLATE}

1. Map showing sampling site locations in the North Umpqua River Basin, Oregon

In pocket

\section{FIGURES}

1. Graphs showing daily mean discharge at three sites in the North Umpqua River Basin, Oregon, 1992-95. 4

2. Schematic diagram showing impoundments, powerhouses, and diversions in the hydroelectric project area of the North Umpqua River Basin, Oregon

3. Graph showing flow duration curves for three sites and simulated streamflow at one site in the North Umpqua River Basin,

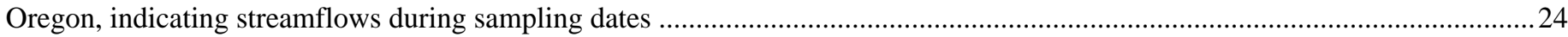

4. Graph showing flow balance in the North Umpqua River Basin, Oregon, July 24-29, $1995 \ldots \ldots \ldots \ldots \ldots \ldots \ldots \ldots \ldots \ldots \ldots \ldots \ldots \ldots \ldots \ldots \ldots \ldots \ldots . . . .25$

5. Graph showing distributions of soluble reactive and total phosphorus concentrations at different site types in the

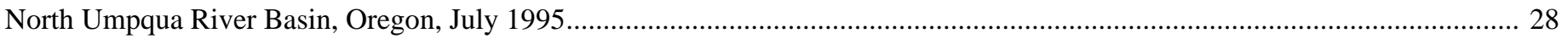

6. Graph showing total phosphorus concentrations in the North Umpqua River Basin, Oregon, July 1995 .......................................30

7. Periphyton abundance at 10 sites in the North Umpqua River Basin, Oregon, July 1995 ...........................................................32

8. Cluster analysis from the Two-Way Indicator Species Analysis (TWINSPAN) and autecological guild summary for sites sampled for benthic algal community composition in the North Umpqua River Basin, Oregon, July 1995 ....................................35

9. Canonical correspondence analysis (CCA) triplot of sites sampled in the North Umpqua River Basin, Oregon, July 1995,

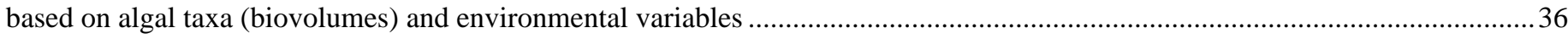

10. Graph showing diel measurements of water temperature, dissolved oxygen, and $\mathrm{pH}$ in the North Umpqua River Basin, Oregon, July 1995

\section{TABLES}

1. Hydrologic characteristics of impoundments within the hydroproject area of the North Umpqua River Basin, Oregon, 7

2. State of Oregon water-quality standards for $\mathrm{pH}$, water temperature, and dissolved oxygen for the North Umpqua River Basin, Oregon

3. Constituents analyzed during reconnaissance sampling at two sites on the North Umpqua River, Oregon, 1993-95.

4. Water-quality sampling sites visited and types of data collected during the synoptic survey of the North Umpqua River Basin, July 24-29, 1995 ....

5. Summary of water-quality analyses conducted in the North Umpqua River Basin, Oregon, 1993-95

6. Comparison of water-chemistry of samples collected and analyzed by the U.S. Geological Survey and by PacifiCorp in the North Umpqua River Basin, Oregon, during July 1995

7. Quality-assurance data for algal abundance (chlorophyll $a$, ash-free dry mass [AFDM], total biovolume, and total cell density) and percent relative biovolumes and densities of autecological guilds from two replicate samples from the North Umpqua River above Rock Creek, Oregon, July 1995

8. Annual discharge statistics for selected sites within the North Umpqua River Basin, Oregon, including the South Umpqua River at Tiller, Oregon, for comparison....

9. Number of algal taxa in major Divisions from 10 sites sampled in the North Umpqua River Basin, Oregon, 1994-95

10. Relative percent biovolumes and percent density by autecological guilds, and dominant algal taxa at sites in the North Umpqua River Basin, Oregon, 1994-95

11. Estimated nitrogen in fertilizer used in the North Umpqua River Basin, Oregon, 1993-95 


\section{CONVERSION FACTORS}

[SI = International System of units, a modernized metric system of measurement $]$

Factors for converting SI metric units to inch/pound units

\begin{tabular}{|c|c|c|}
\hline Multiply & By & To obtain \\
\hline \multicolumn{3}{|c|}{ Length } \\
\hline micrometer $(\mu \mathrm{m})$ & 0.00003937 & inch (in) \\
\hline millimeter (mm) & 0.03937 & inch \\
\hline meter $(\mathrm{m})$ & 3.281 & foot $(\mathrm{ft})$ \\
\hline kilometer $(\mathrm{km})$ & 0.621 & mile (mi) \\
\hline \multicolumn{3}{|c|}{ Volume } \\
\hline milliliter (mL) & 0.001057 & quart (qt) \\
\hline liter $(\mathrm{L})$ & 1.057 & quart \\
\hline liter & 0.2642 & gallon (gal) \\
\hline \multicolumn{3}{|c|}{ Mass } \\
\hline microgram $(\mu \mathrm{g})$ & 0.00000003527 & ounce \\
\hline milligram (mg) & 0.00003527 & ounce \\
\hline $\operatorname{gram}(\mathrm{g})$ & 0.03527 & ounce \\
\hline kilogram (kg) & 35.27 & ounce \\
\hline \multicolumn{3}{|c|}{ Area } \\
\hline square kilometers $\left(\mathrm{km}^{2}\right)$ & 0.3861 & square miles $\left(\mathrm{mi}^{2}\right)$ \\
\hline hectares (ha) & 2.471 & acres $(\mathrm{ac})$ \\
\hline square kilometers $\left(\mathrm{km}^{2}\right)$ & 247.105 & acres (ac) \\
\hline square meters $\left(\mathrm{m}^{2}\right)$ & 10,000 & hectares (ha) \\
\hline \multicolumn{3}{|c|}{ Density } \\
\hline grams per cubic centimeter $\left(\mathrm{g} / \mathrm{cm}^{3}\right)$ & 0.5780 & ounces per cubic inch $\left(\mathrm{oz} / \mathrm{in}^{3}\right)$ \\
\hline \multicolumn{3}{|c|}{ Temperature } \\
\hline degrees Celsius $\left({ }^{\circ} \mathrm{C}\right)$ & $\left({ }^{\mathrm{a}}\right)$ & degrees Fahrenheit $\left({ }^{\circ} \mathrm{F}\right)$ \\
\hline \multicolumn{3}{|c|}{ Concentration, in Water } \\
\hline micrograms per liter $(\mu \mathrm{g} / \mathrm{L})$ & 1 & parts per billion (ppb) \\
\hline milligrams per liter $(\mathrm{mg} / \mathrm{L})$ & 1 & parts per million (ppm) \\
\hline \multicolumn{3}{|c|}{ Concentration, in Sediment } \\
\hline micrograms per gram $(\mu \mathrm{g} / \mathrm{g})$ & 1 & parts per million (ppm) \\
\hline
\end{tabular}

${ }^{\text {a }}$ Temperature ${ }^{\circ} \mathrm{F}=1.8\left(\right.$ Temperature $\left.{ }^{\circ} \mathrm{C}\right)+32$

Sea level: In this report "sea level" refers to the National Geodetic Vertical Datum of 1929 (NGVD of 1929)—a geodetic datum derived from a general adjustment of the first-order level nets of both the United States and Canada, formerly called Sea Level Datum of 1929. 
Page Intentionally Blank 


\section{GLOSSARY, INCLUDING SITE ACRONYMS, SYMBOLS, AND ABBREVIATIONS}

Site Acronyms

\begin{tabular}{|c|c|}
\hline BOULM & Boulder Creek near mouth \\
\hline BSODA & North Umpqua River below Soda Springs Powerhouse \\
\hline CALFM & Calf Creek near mouth \\
\hline CANTM & Canton Creek near mouth \\
\hline CLRAS & Clearwater River above Stump Lake \\
\hline CLR2B & Clearwater River above Toketee Lake \\
\hline COPEG & North Umpqua River above Copeland Creek \\
\hline COPEM & Copeland Creek near mouth \\
\hline FISHA & Fish Creek above Fish Creek Diversion \\
\hline FISHB & Fish Creek at mouth \\
\hline FISHP & Fish pond below Soda Springs Reservoir \\
\hline INLET & North Umpqua River above Lemolo Lake near Inlet Campground \\
\hline LAKEM & Lake Creek above Lemolo Lake \\
\hline LEM1G & North Umpqua River below Lemolo Lake \\
\hline LEM1T & Top of Lemolo 1 bypass reach \\
\hline LEM2B & North Umpqua River above Lemolo No. 2 Powerhouse \\
\hline LEM2FF & North Umpqua River below Lemolo No. 2 Powerhouse \\
\hline LITGL & Little River near Glide \\
\hline LTBLK & Little River above Black Creek \\
\hline LTWLF & Little River at Wolf Creek Job Center \\
\hline MOTTB & North Umpqua River at Mott Bridge \\
\hline NUAPC & North Umpqua River at Apple Creek \\
\hline NUBWC & North Umpqua River below Steamboat Creek \\
\hline NURCR & North Umpqua River above Rock Creek \\
\hline NURCM & Water-quality monitor on North Umpqua River above Rock Creek \\
\hline NUSTM & North Umpqua River near Steamboat \\
\hline NUGLD & North Umpqua River near Glide \\
\hline PANTM & Panther Creek near mouth \\
\hline ROCKM & Rock Creek near mouth \\
\hline SEEPS & Seep at left bank below Soda Springs Reservoir \\
\hline SODAT & North Umpqua River below Soda Springs \\
\hline STEABB & Steamboat Creek above Big Bend Creek \\
\hline STEAM & Steamboat Creek at gage \\
\hline SUSNM & Susan Creek near mouth \\
\hline TOKET & North Umpqua River below Toketee Lake \\
\hline TOKLKI & North Umpqua River above Toketee Lake \\
\hline WRCRM & Wright Creek near mouth \\
\hline
\end{tabular}

$\%$

${ }^{\circ} \mathrm{C}$

$\mu \mathbf{m}^{3}$

$\mu \mathrm{m}^{3} / \mathrm{cm}^{2}$

cells $/ \mathrm{cm}^{2}$

$\mathrm{ft}^{3} / \mathrm{s}$

mg/kg

$\mathrm{mg} / \mathrm{L}$

$\mathrm{mg} / \mathrm{m}^{2}$

$\mu \mathrm{g} / \mathrm{L}$

mi $^{2}$

$\mathbf{m L}$
Symbols, Abbreviations, and Terms

Boulder Creek near mouth

Calf Creek near mouth

Canton Creek near mouth

Clearwater River above Stump Lake

Clearwater River above Toketee Lake

Copeland Creek near mouth

Fish Creek above Fish Creek Diversion

Fish Creek at mouth

Fish pond below Soda Springs Reservoir

Lake Creek above Lemolo Lake

North Umpqua River below Lemolo Lake

North Umpqua River below Lemolo No. 2 Powerhouse

Little River at Wolf Creek Job Center

North Umpqua River at Mott Bridge

orth Umpqua River at Apple Cree

North Umpqua River above Rock Creek

Water-quality monitor on North Umpqua River above Rock Creek

North Umpqua River near Steamboat

North Umpqua River near Glide

Panther Creek near mouth

Rock Creek near mouth

North Umpqua River below Soda Springs

Steamboat Creek above Big Bend Creek

North Umpqua River below Toketee Lake

Wright Creek near mouth

Percent.

Degree Celsius.

Cubic micrometers

Cubic micrometers per square centimeter, a measure of algal biovolume.

Cells per square centimeter, a measure of cell density.

Cubic feet per second, measure of streamflow.

Milligrams per kilogram of sediment, or parts per million.

Milligrams per liter of water, or parts per million.

Milligrams per square meter.

Micrograms per liter of water, or parts per billion.

Square miles.

Milliliter, or $10^{-3}$ liters. 
$\mu \mathbf{m}$

abiotic

accretion

AMA

AFDM

algal bloom

algal community

algal production

algal sloughing

alkalinity

alkaliphilic (algal) taxa

allochthonous

ambient water quality

anadromous fish

attached algae

autecological guilds

autochthonous

basal cells

bed sediment

benthic

benthic algal mats

bicarbonate

biomass

biovolume

BLM

blue-green algae

bypass reach

CCA

\section{channel morphology \\ chironomids \\ chlorophyll $a$ \\ $\mathrm{CO}_{2}$}

cold-water (algae) taxa

colloids

colonial
Micrometer, or $10^{-6}$ meters.

Characterized by the absence of life or living resources.

An increase by natural growth or by gradual external addition.

Adaptive Management Area-An AMA is designed to develop and test new management approaches to integrate and achieve ecological, economic, and other social and community objectives in forested areas.

Ash-free dry mass, a measure of the organic content of a biological sample.

A rapid increase in the amount of algae in a specified water body.

The grouping of different species of algae in a water body.

The rate of assimilation or growth of an algal community.

Breaking off and downstream transport of mats of attached algae, from internal (autogenic) or external (scour) causes.

A measure of the capacity of water to react with and neutralize an acid.

Algae that occur primarily at $\mathrm{pH}$ values near or higher than 7.

Derived from external sources, originating elsewhere.

Background or prevailing water quality.

Fish species that are born in freshwaters, spend part of their adult life in marine waters, and return to freshwaters to spawn.

See "periphyton."

Groups of species which share a resource in a community and have similar ecological tolerances, requirements, or abilities.

Derived from internal sources, originating in place.

Cells at or near the base or interior of an algal mat.

Soils or sediment located at the bottom of a water body.

Referring to organisms living on or near the bottom of a water body.

Mats of algae attached to the streambed or particles resting on the streambed.

The ion $\mathrm{HCO}_{3}{ }^{-}$, which is an intermediary in the dissociation of carbonic acid $\left(\mathrm{H}_{2} \mathrm{CO}_{3}\right)$. Bicarbonate is critical in both photosynthetic pathways and reactions of minerals contributing to alkalinity.

The total mass of organisms occupying a given trophic level or defined area.

The total volume of organisms occupying a given trophic level or defined area.

Bureau of Land Management

A group of unicellular, colonial, or filamentous prokaryotic organisms that contain no nuclear membrane but do contain chlorophyll or other pigments. They resemble bacteria more than algae.

A formerly natural stream channel below an impoundment into which a minimum amount of water flows as specified by permit. The remaining water that is discharged from the impoundment is carried by diversion and canal to a power generating facility.

Canonical Correspondence Analysis, a quantitative statistical technique that allows for evaluation and testing of significance of relations between environmental variables and species.

The classification of the physical features of a stream channel.

A family of macroinvertebrates of the order Diptera (flies) that live in streams for part of their life cycle.

A green pigment in plants and algae that absorbs light and is important in photosynthesis.

Carbon dioxide.

Groupings of algae that occur primarily at water temperatures below 15 degrees Celsius.

Microparticles, or macromolecules, that are small enough to move primarily by random motion (as opposed to gravitational settling), but are large enough to provide a microscopic environment into or onto which molecules of interest can escape an aqueous solution.

Existing or growing in a group or cluster. 


\section{CPOM}

detritus

diatom

diatom frustule

diel

discharge

DO

DOC

DOM

embeddedness

endosymbiotic

epilimnion

epiphyte

epithemiacean

eutrophic taxa

eutrophic

EWI

facultative

FERC

filamentous

fixation

fixed site

fluvial

forebay

FPOM

full-flow reach gastropod

GC/MS

GCC bottle

GF/F

glide

gravimetric

grazer

green algae

guild

herbivorous

heterocyst

heterotrophs

Coarse-grained particulate organic matter.

Dead microscopic organic matter.

Unicellular, filamentous, or colonial algae with cell walls that are made out of silica and that may be highly sculpted.

The shell of a diatom.

Involving or encompassing a 24-hour period.

Streamflow rate, usually given in cubic feet per second.

Dissolved oxygen.

Dissolved organic carbon.

Dissolved organic matter.

A measure of the amount of fine material covering rock substrates in a streambed, given in percent.

Living inside another organism, and providing a mutually beneficial relationship.

The surface layer in a stratified water body.

A plant that grows nonparasitically on the exterior of another living organism.

Of or belonging to the diatom family Epithemiaceae, and which are relatively large and which frequently contain endosymbiotic, nitrogen fixing structures.

A grouping of algae that occur primarily in waters with high nutrient or organic content.

The state of a water body being overly enriched by plant nutrients, especially nitrogen and phosphorus.

Equal-Width Increment.

Capable of taking advantage of differing environmental conditions.

Federal Energy Regulatory Commission.

Growing or existing in elongated strands.

The utilization of elemental nitrogen $\left(\mathrm{N}_{2}\right)$ from air or aqueous phases.

A location sampled on a regular or semiregular basis.

Pertaining to or derived from the physical action of rivers.

A water body constructed specifically to provide a steady source of water to a power generating facility. Used in this report to refer to off-channel water bodies.

Fine-grained particulate organic matter.

A stretch of river that has no water diverted from the main channel.

A class of mollusks whose freshwater members include principally snails and limpets.

Gas Chromatography / Mass Spectroscopy.

1-liter amber glass bottle.

Glass-fiber filter.

A calm stretch of shallow water flowing smoothly.

Referring to measurement of a desired constituent by combustion or drying and weighing.

An animal that forages on plants. In this report the term generally refers to aquatic macroinvertebrates that consume attached algae.

Algae belonging to the plant division Chlorophyta. They generally must obtain nutrients (nitrogen and phosphorus) from dissolved, inorganic forms.

A grouping of species sharing a similar ecological niche.

Eating only plant material.

A specialized cell with thick, clear walls that occurs in some blue-green algae and that contains an enzyme required for fixing atmospheric nitrogen.

Organisms that use organic compounds as sources of energy and nourishment. 
heterotrophic

\section{HPLC}

hydraulic residence time

hydrologic

hydroproject

hypolimnion

hyporheic zone

impoundment

inorganic

internal loading

isotopes

labile

lentic

limitation

liter bags

load

lotic

LWD

macroinvertebrate

mesotrophic

metabolism

midge

minimum instream flow

MRL

mucilaginous

multivariate analysis

N:P ratio

native water

NAWQA

$\mathrm{NH}_{4}{ }^{+}$

nitrification

nitrogen fixing taxa

nitrogen heterotroph

$\mathrm{NO}_{2}{ }^{2-}$

$\mathrm{NO}_{3}{ }^{-}$

nonpoint
Obtaining energy by consumption or incorporation of organic materials.

High Performance Liquid Chromatography.

The average amount of time a unit of water is expected to spend in a given water body.

Of or pertaining to the study or movement of water and its interaction with its surroundings.

A structure or series of structures that generate electricity from the movement of water.

A layer of water at the bottom of a stratified water body such as a lake or reservoir.

A zone in the subsurface area near and under a stream that has a close hydrologic connection with stream waters.

A water body created by the obstruction of flow in a stream or canal.

Pertaining to or composed of chemical compounds that do not contain carbon as the principal element; that is, matter other than plant or animal.

The contribution to water of nutrients derived from in-lake or in-sediment processes.

One of two or more atoms having the same atomic number but different mass number.

Readily changed, as by heat, oxidation, or other processes. Capable of reacting.

Of or pertaining to stationary water.

Control of growth by a particular physical element or chemical that is in short supply.

Mesh bags filled with leaf material and other organic debris that can be placed in streams to experimentally assess macroinvertebrate colonization.

The mass of a particular constituent transported by a given location over a specified time.

Of or pertaining to flowing water.

Large woody debris.

Animals having no skeleton, generally in water, that are visible without visual aid.

The state of a water body being moderately enriched by plant nutrients.

All the chemical reactions that take place within a living organism and that require energy.

See "chironomids."

The amount of water, specified by permit or license, that is necessary to be maintained in a stream channel for the benefit of aquatic biota.

Minimum reporting level, the lowest concentration of a constituent that may be reliably reported using a given analytical method.

Composed of a thick, sticky material.

Analysis of multiple variables that together have many dimensions.

Nitrogen to phosphorus ratio, an index that can indicate potential nutrient limitation.

Undisturbed water taken from or found in the environment at a given location.

USGS National Water-Quality Assessment Program.

Dissolved ammonium nitrogen. Used in this report to indicate nitrogen as either ammonium or ammonia $\left(\mathrm{NH}_{3}\right)$, regardless of $\mathrm{pH}$.

The biological conversion of ammonia or ammonium to nitrate.

A group of algae that are capable of utilizing elemental nitrogen $\left(\mathrm{N}_{2}\right)$ as a nitrogen source.

A species that is capable of utilizing organic matter as a nitrogen source.

Dissolved nitrite nitrogen.

Dissolved nitrate nitrogen.

Coming from diffuse sources that cannot be easily defined. 
nutrients

nutrient limiting

nutrient recycling

nutrient spiraling

nutrient uptake

NWQL

ODL

oligotrophic

oligotrophic (algal) taxa

PCB

penstock

periphyton

pH

photosynthesis

phototrophs

phytoplankton

$\mathrm{PO}_{4}{ }^{3-}$

powerhouse

primary productivity

reach

reaereation

recharge

recurrence intervals

recycling

remineralization

reservoir

respiration

retention time

richness

riparian

RM

RTH

saturation

Section 303(d)

senescence

SNTEMP

SOC

SRP

spatial variability
Organic and inorganic chemicals necessary for the growth and reproduction of organisms. In general, the term is used to refer to nitrogen or phosphorus, but it may refer to other chemicals as well.

Controlling growth or reproduction of an organism by its requirement for nutrients.

The use and reuse of nutrients in water, typically at a rapid pace and within a small area.

The transport and recycling of nutrients through water and the various members of an aquatic food web.

The consumption of nutrients from the water column by aquatic organisms.

The USGS National Water-Quality Laboratory in Arvada, Colorado

The USGS Oregon District Laboratory.

The state of a water body being minimally enriched by plant nutrients.

Algae that require low concentrations of nutrients and are intolerant of high concentrations.

Polychlorinated biphenyl organic compounds.

A closed conduit that carries water from intake to turbine in a hydroelectric system.

An assemblage of attached aquatic organisms including bacteria, algae, fungi, and protozoans.

A measure of the acidity of a solution. Calculated as $-\log \left(\right.$ concentration of $\mathrm{H}^{+}$ion).

The growth and maintenance of living cells of organic compounds using light energy.

Organisms capable of using light as an energy source.

Algae that are free floating (as opposed to attached) in a water body.

Orthophosphate phosphorus, the predominant form of dissolved phosphorus (filtered).

A building containing the turbines for power generation in a hydroelectric system.

The conversion of nutrients and light into organic tissue by photosynthesis.

A specified section of river.

The process of entrainment of air and its gases (nitrogen, oxygen, and carbon dioxide) into water in response to a physical or biological driving force.

The movement of water from surface systems to ground-water systems.

A statistically derived time period within which a given event is expected to happen once.

See "nutrient recycling."

The process of conversion of organic forms of compounds into their inorganic components.

A natural or artificial lake used for water storage for industrial and domestic purposes.

The biological process of converting organic matter into carbon dioxide and water with the release of energy. The reverse process of photosynthesis.

See "hydraulic residence time."

The number of different species of a given taxonomic level in a biological sample.

Pertaining to land bordering a water body.

River mile.

Richest Targeted Habitat, a specific habitat type (pool, riffle, glide, or run) that is expected to provide the greatest algal species richness. In the North Umpqua River, the RTH was riffle-habitats.

The state in which a compound or element is dissolved in an equilibrium amount.

Section of the Clean Water Act requiring management plans for water-quality limited streams.

The process of decaying or dying.

A computer model used for predicting water temperature.

Suspended organic carbon.

Soluble reactive phosphorus, or filtered and undigested phosphorus, most of which is composed of $\mathrm{PO}_{4}^{3-}$ but which may contain dissolved polyphosphates or other forms.

Variation over a geographic area. 
SPE

standing crop

steelhead

STORET

stratify

substrate

succession

synoptic

tailrace

taxon (plural taxa)

TDN

TDP

TDS

temporal variability

thermocline

TKN

TMDL

TP

triplot diagram

trophic level

TWINSPAN

unicellular

urea

USEPA

USFS

USGS

vacuole

watershed

WATSTORE

Wild and Scenic reach
Solid phase extraction.

The amount of living matter (biomass) of one or more species present in a given area.

A species of trout that spends part of its adult life in the sea but spawns in freshwater.

Storage and retrieval system, a water quality data base maintained by the USEPA.

To break down or divide into discrete units or layers.

The surface to which an organism is attached or on which it moves.

A change in species from one point in time and space to another.

A type of water-quality sampling that occurs during one short time period to provide a snapshot of conditions.

A channel for dissipation of energy and carrying water away from a turbine.

Any named taxonometric group, regardless of ranking (for example, genus or variety).

Total dissolved organic plus ammonium nitrogen (filtered, digested).

Total dissolved phosphorus (filtered, digested).

Total dissolved solids.

Variation over time.

An area in a lake or reservoir where temperature changes rapidly with depth.

Total organic plus ammonia nitrogen (unfiltered, digested).

Total Maximum Daily Load, the maximum amount of material a given water body can absorb without adverse effects.

Total phosphorus (unfiltered, digested).

A visual representation of the results of Canonical Correspondence Analysis.

The nutrient status of a water body, or the level within a food web.

Two Way Indicator Species Analysis program for cluster analysis of multispecies data.

Being composed of just one cell.

A product of protein metabolism that breaks down to ammonium and is found in urine. Commonly used as fertilizer.

U.S. Environmental Protection Agency.

U.S. Department of Agriculture-Forest Service.

U.S. Geological Survey.

A fluid filled space inside the cytoplasm, more common in plant cells than animal cells.

A collecting area into which surface water drains, and having one common outlet.

Water storage and retrieval system, a water quality database maintained by the USGS.

A 32-mile section of the main-stem North Umpqua River from Boulder Creek to Rock Creek, below the hydroelectric project area, that is part of the National Wild and Scenic River system. 


\section{ACKNOWLEDGMENTS}

This report was prepared in cooperation with Douglas County, with help from Mikeal Jones, of the Umpqua National Forest, and Frank Shrier of PacifiCorp. This report, and indeed data collection in the North Umpqua River Basin, was made possible by the efforts of Mikeal Jones as part of his determination to conscientiously manage the water quality in the North Umpqua River Basin. PacifiCorp generously provided facilities for and participated in data collection during the 1995 synoptic survey, and has provided data and assistance freely. Mark Powell of Colliding Rivers Research is also acknowledged for his early recognition of the potential for water-quality problems within the North Umpqua Basin. Mary Power, from the University of California at Berkeley, contributed information on algal ecology, and was instrumental in helping in the development of hypotheses and conceptual understanding of the role of hydropower and flow regulation on water quality and algal ecology. Mike Bonoff, from Harza Northwest, Inc., and Todd Olson, from PacifiCorp, assisted in field work and data interpretation and provided reviews of document drafts. Reviews were also provided by Bob Coats of Stillwater Sciences and Linda Prendergast of PacifiCorp.

Within the U.S. Geological Survey, Jim Caldwell planned and coordinated field efforts in July 1995, and Mike Gentile, Micelis (Clyde) Doyle, Howard Harrison, Ted Pogue, Tammy Wood, and Dorie Brownell contributed valuable field help. Ian Waite and Joe Rinella contributed their time and assistance in understanding and analysis of algal and water-quality data, respectively. James Kuwabara, Dennis Wentz, Joseph Rinella, and Frank Rinella, together with Mikeal Jones, provided helpful reviews and suggestions on report structure and content. Editorial assistance was provided by John Williams and Thelma Parks, and the report was formatted and produced with assistance from Jennifer Morace, Thelma Parks, Donita Parker, and Jacqueline Olson. 
Page Intentionally Blank 


\title{
Water-Quality and Algal Conditions in the North Umpqua River Basin, Oregon, 1992-95, and Implications for Resource Management
}

\author{
By Chauncey W. Anderson and Kurt D. Carpenter
}

\begin{abstract}
This report describes the results of a synoptic waterquality and algal investigation during July 1995 at 36 stream sites in a 1,350 square-mile area of the North Umpqua River Basin, Oregon. The study area includes a headwaters hydroelectric project area, a Wild and Scenic reach in the main stem immediately downstream, and the watersheds of several major tributaries. Additional data from previous investigations are reviewed, and impacts on water quality in the Wild and Scenic reach from resource management, including forestry and reservoir operations, are inferred where sufficient data exist.
\end{abstract}

Water-quality standards were occasionally exceeded for dissolved oxygen and $\mathrm{pH}$, and daily maximum stream temperatures in the Wild and Scenic reach were higher than both the 1996 standard for the State of Oregon and the optimal temperature ranges for many anadromous fish. Dissolved oxygen in the basin was controlled more by stream temperature and reaeration than by primary production. Arsenic concentrations in the river during low flow $(1 \mu \mathrm{g} / \mathrm{L}$ [microgram per liter]) indicate a potential cancer risk of between 1:5,000 and 1:20,000 for people using the river as a source of drinking water and fish for consumption. Streambed-sediment concentrations of arsenic, chromium, copper, manganese, and nickel were approximately double the sediment-quality criteria values adopted by New York State and by the Ontario Ministry of the Environment.

High concentrations of phosphorus in bed sediments indicated that much of the phosphorus observed in the water column throughout the basin (medians: 32, 9, and 50 $\mu \mathrm{g} / \mathrm{L}$ in the main stem, tributaries, and hydroelectric project areas, respectively) could have been geologically derived. Inorganic and organic nitrogen concentrations in water were mostly below minimum reporting limits ( 5 and 200 $\mu \mathrm{g} / \mathrm{L}$, respectively), indicating severe nitrogen limitation at most locations.
Benthic algal biomass, biovolume, and chlorophyll $a$ concentrations were highest at the sites directly below impoundments and at one headwater tributary (medians: 46 grams per square meter, 821 million cubic micrometers per square centimeter, and 126 milligrams per square meter, respectively), and were also somewhat elevated downstream in the Wild and Scenic reach compared with those in similar streams in the Pacific Northwest. Classification of the algal taxa indicated that, among all sites sampled, alkaliphilic taxa, nitrogen fixing taxa, and eutrophic taxa were the most abundant on the basis of biovolume and density. Cold-water taxa, facultative nitrogen heterotrophs, and oligotrophic taxa constituted the remainder of the taxa. Multivariate analyses indicated that algal communities at the hydroelectric-project-affected sites were distinct from communities at sites on the main stem and Steamboat Creek. At many locations, the river's algal community might be compensating for the low nitrogen concentrations by fixation of atmospheric nitrogen or through heterotrophic assimilation of organic nitrogen.

Water quality in the Wild and Scenic reach is dominated by water released from the hydroelectric project area during summer. Effects of the hydroelectric project include seasonal control of streamflow, water temperature, and phosphorus concentrations, and the possible release of low but ecologically important concentrations of organic nitrogen. A review of available data and literature suggests that the reservoirs can increase the interception of sediments and large organic debris, and promote their conversion into fine-grained particulate and dissolved organic matter for downstream transport. These effects could be compounded by the effects of forestry in the basin, including alteration of hydrologic cycles, changes in sediment and nutrient runoff, reductions of the transport of large woody debris, and degradation of habitat quality. It is hypothesized that, in the North Umpqua River, these processes have induced a fundamental shift in the river's food web, from a detritus-based system to a system with a 
higher emphasis on algal production. Confirmation of these changes and their effects on higher trophic levels are needed to properly manage the aquatic resources for all designated beneficial uses in the basin.

\section{INTRODUCTION}

The North Umpqua River, which flows westward from the Oregon Cascades to its confluence with the South Umpqua River and ultimately, as the Umpqua River, to the Pacific Ocean, is known for its scenic beauty, outstanding recreational opportunities, and importance as a natural resource. Designated beneficial uses include water for drinking, irrigation, and livestock; anadromous fish passage, spawning, and rearing; habitat for resident fish and aquatic life; fishing; water contact recreation; and hydropower (Oregon Administrative Rules, Chapter 340, Division 41, Rule Number 340-41-282, 1994). The river basin is also known for its prolific production of timber, notably douglas fir, Pacific silver fir, shasta red fir, grand fir, ponderosa pine, sugar pine, western white pine, incense cedar, western red cedar, and western hemlock from public as well as commercial forest lands.

Recent attention on management of these natural resources, including issues such as threatened or endangered fish species, timber production, and hydropower generation, has resulted in increased scrutiny of the water quality in this stream and the factors influencing water quality. Whereas stream temperatures in the basin have been studied intensively by the U.S. Forest Service, the Bureau of Land Management (BLM), academia, and fishermen's groups, other water-quality aspects had been largely neglected until the late 1980's. A water-quality index used by the Oregon Department of Environmental Quality indicates a slight decline in water quality, near the mouth of the river at Winchester, during the 11-year period from 1984 through 1994, most likely as a result of increases in biochemical oxygen demand (BOD), total phosphate, and bacteria counts in nonpoint-source pollution of undetermined origin (Curtis Cude, Oregon Department of Environmental Quality, WWW page <http://www.deq.state.or.us/lab/wqm/wqi/umpqua/ umpqua4.htm>, accessed March 26, 1998). Although resident trout populations in the basin are considered stable, there is concern for anadromous fish runs, including summer and winter steelhead, spring and fall chinook salmon, and coho salmon, largely because hatchery programs may be masking or contributing to declines in the populations of wild-fish stocks. Despite the relatively stable populations of coho salmon in the North Umpqua River Basin, their decline in other coastal watersheds prompted the National Marine Fisheries Service to propose listing coastal coho populations, including those in the North Umpqua River Basin, as "Threatened" under the Federal Endangered Species Act in 1996. The National Marine Fisheries Service also proposed listing North Umpqua River cutthroat trout, both anadromous and resident populations, as Threatened. Pacific Lamprey are listed as "Sensitive" by the State of Oregon and may be candidates for listing as Threatened at some point in the future (Marshall and others, 1996).

\section{Background}

In the Pacific Northwest, many hydroelectric facilities' licenses, which are administered by the Federal Energy Regulatory Commission (FERC), will expire by the year 2000. In the North Umpqua River Basin, the 50-year license for the hydroelectric project in the headwaters (pl. 1) expired in January 1997. As part of the relicensing process, the current project operator, PacifiCorp, conducted a series of technical studies, including water-quality studies, from 1992 through 1994 in impoundments and streams encompassed by the hydroelectric project (PacifiCorp, 1994a; PacifiCorp, 1994b; PacifiCorp, 1995a, volumes 1-42)

Although data collected by PacifiCorp were useful as an initial assessment of the water quality within the hydroelectric project area (hereafter referred to as "the hydroproject area") few data were available to describe conditions in the river downstream. At the request of the U.S. Forest Service, data were collected by the U.S. Geological Survey (USGS), beginning in 1993, at two downstream sites in order to provide baseline, reconnaissance-level information regarding general water-quality conditions in the Wild and Scenic reach of North Umpqua River.

Initial findings from the studies conducted by the USGS, PacifiCorp, and the U.S. Forest Service (Powell, 1995) indicated that issues related to potential eutrophication (including nutrients, benthic algae, and their effects on dissolved oxygen, $\mathrm{pH}$, and the benthic community) were of the most immediate concern. Furthermore, the degree to which these issues are affected by resource-management activities in the basin needed to be understood to more effectively manage the basin for all of the designated beneficial uses.

On the basis of results of the initial investigations, the USGS, in cooperation with Douglas County and with input and coordination from the U.S. Forest Service and PacifiCorp, conducted a study of nutrients, algae, dissolved oxygen (DO), and $\mathrm{pH}$ in the North Umpqua River Basin in July 1995. The study area included the main stem of the river and its tributaries along the Wild and Scenic reach downstream from the hydroproject area as well as several sites within the hydroproject area and within the adjacent Little River watershed (pl. 1). Also included were parts of the Steamboat Creek watershed, which contributes a large proportion of the flow to the Wild and Scenic reach and is important as spawning habitat for steelhead.

\section{Purpose and Scope}

The primary purpose of this report is to provide a description of streamflow, water quality, and algal characteristics in the North Umpqua River Basin, integrating data from the hydroproject area and the Wild and Scenic reach, during low-flow conditions. Major nutrient sources and sinks, and possible nutrient-limiting conditions derived by mass balancing streamflows and nutrient loads in the North Umpqua River from Soda Springs Reservoir to Glide, are identified. Where possible, relations are drawn among algal conditions, stream chemistry, and physical components of the river system. A review of 
relevant local water-quality issues associated with algal growth and resource-management activities is also provided.

The report also describes concentrations of trace elements and organic compounds in water during low- and high-flow periods and in streambed sediment during low-flow periods, in samples collected from 1993 through 1995, and presents assessments of water quality relative to State of Oregon standards and guidelines for $\mathrm{DO}, \mathrm{pH}$, water temperature, chlorophyll $a$, trace elements, and organic compounds.

Finally, the report contains an assessment of the suitability of existing data to answer questions regarding the effects that activities such as forest management and hydropower generation have on water quality and algae. A conceptual model of potential effects from these land uses is proposed and, on the basis of an analysis of gaps in the existing data, recommendations are made for possible future studies on issues of concern within the basin.

Data used in this report were drawn from a variety of sources, but primarily from a synoptic survey in July 1995 by the USGS and PacifiCorp. The USGS and PacifiCorp have collected additional data in the basin from 1991 through 1995, including data from a monitor upstream from Rock Creek, which measured stream temperature, DO, $\mathrm{pH}$, and specific conductance hourly, during 1993-95, and water and bed-sediment data collected at two main-stem sites (referred to herein as "fixed" sites) located upstream from Rock Creek and at Wright Creek during 1993-95. These data are used for reference purposes or to augment the analysis of synoptic survey results.

Relevant findings from PacifiCorp's monitoring program in streams, impoundments, and forebays during 1992-94 (PacifiCorp, 1995a, volumes 1-4) and results of stream surveys in the Little River watershed (Powell, 1995; U.S. Forest Service and Bureau of Land Management, 1995) are reviewed in light of data collected during the synoptic survey in July 1995 and are used to augment the available data. Nutrient data collected by PacifiCorp during July 1995, which were previously reported (PacifiCorp, 1995b), are also given here, in Appendix D, for ease of comparison with USGS data. Data and findings from an ongoing watershed analysis in the North Umpqua River Basin, including the Wild and Scenic reach and the hydroproject area (PacifiCorp, 1997) were considered beyond the scope of this report because of their draft nature.

\section{Study Area}

The North Umpqua River Basin, which covers approximately 1,350 square miles $\left(\mathrm{mi}^{2}\right)$, is located within the Umpqua River Basin in western Oregon (pl.1). The area considered for this report is from the headwaters to the town of Glide, an area of approximately $1,209 \mathrm{mi}^{2}$. For the purposes of this report, the study area is divided into four major sections: (1) the hydroproject area, (2) the Wild and Scenic reach and beyond to Glide, (3) the Steamboat Creek Basin, and (4) the Little River watershed. The study area includes primarily three distinct geologic units, which, together with the elevation and weather, exert important influences on the hydrologic regime and chemistry of the river and its tributaries.

\section{Climate}

The climate of the basin is typical of the temperate, maritime regime of the western Cascade Range and is characterized by cool, wet winters and warm, dry summers. The snow level during the winter is generally between 3,000 and 5,000 feet above sea level, and 80 percent $(\%)$ of the annual precipitation falls between October 1 and March 1 (PacifiCorp, 1995a, volume 3 ) as either rain or snow. Approximately $20 \%$ of the basin lies above 5,000 feet. By contrast, only about $3 \%$ of the adjacent South Umpqua River Basin lies above 5,000 feet (Rinella, 1986).

As a result of the high elevations in the headwaters of the North Umpqua River Basin, a principal driving force for the hydrologic budget is snowmelt. Because much of the upper part of the basin (upstream from Soda Springs Reservoir) receives substantial winter snowfalls, and because ground-water inputs are large, flows from streams originating within the hydroproject area tend to be relatively evenly distributed throughout the year. In contrast, streams such as Steamboat Creek and the Little River, which originate at lower elevations, are more dominated by winter rainfall runoff and summer low flows (see fig. 1). This latter pattern is typical of the flow patterns in the South Umpqua River Basin, where many streams have excessive algal growth and associated water-quality problems during summer low-flow periods (Tanner and Anderson, 1996).

\section{Geology}

The North Umpqua River Basin straddles three major physiographic provinces: the High Cascades, the Western Cascades, and the Klamath Mountains (McKee, 1972; PacifiCorp, 1995a, volume 3). The upper part of the hydroproject area, from approximately Fish Creek on the southwestern edge to just upgradient of the Lemolo No. 2 powerhouse and including the Lemolo No.1 and Clearwater No. 1 power generating developments, is located within the High Cascades. The Quaternary-Tertiary rocks of the province range from 0 to 3,000 feet in thickness, and comprise andesite, basalt, pyroclastic rock, and other flow material. The pyroclastic rocks include ash and pumice from the eruption of Mount Mazama, resulting in variable but often high permeability and areas of locally high recharge. Yields from wells in these rocks have been reported to be as high as 300 gallons per minute, and discharges from springs issuing from the unit are frequently large. Ground- and surface-water drainage basins in this area do not always coincide (McFarland, 1983). As a result of this geological structure, streams originating in the upper portions of the hydroproject area tend to have a large component of ground water throughout much of the year. Soils in the High Cascades are relatively stable and retain nutrients (especially phosphorus) poorly; most nutrients are within the upper 4 to 8 inches of soil (PacifiCorp, 1995a, volume 3 ).

The Tertiary volcanic rocks of the Western Cascades can be up to 15,000 feet thick and include andesite, basalt, conglomerated and agglomerated pyroclastic flow material, and tuff. Recharge and well yields are generally low (McFarland, 1983). Soils here are derived from volcanic rock, which tends to be high in nutrient content, particularly phosphorus (Dillon and 


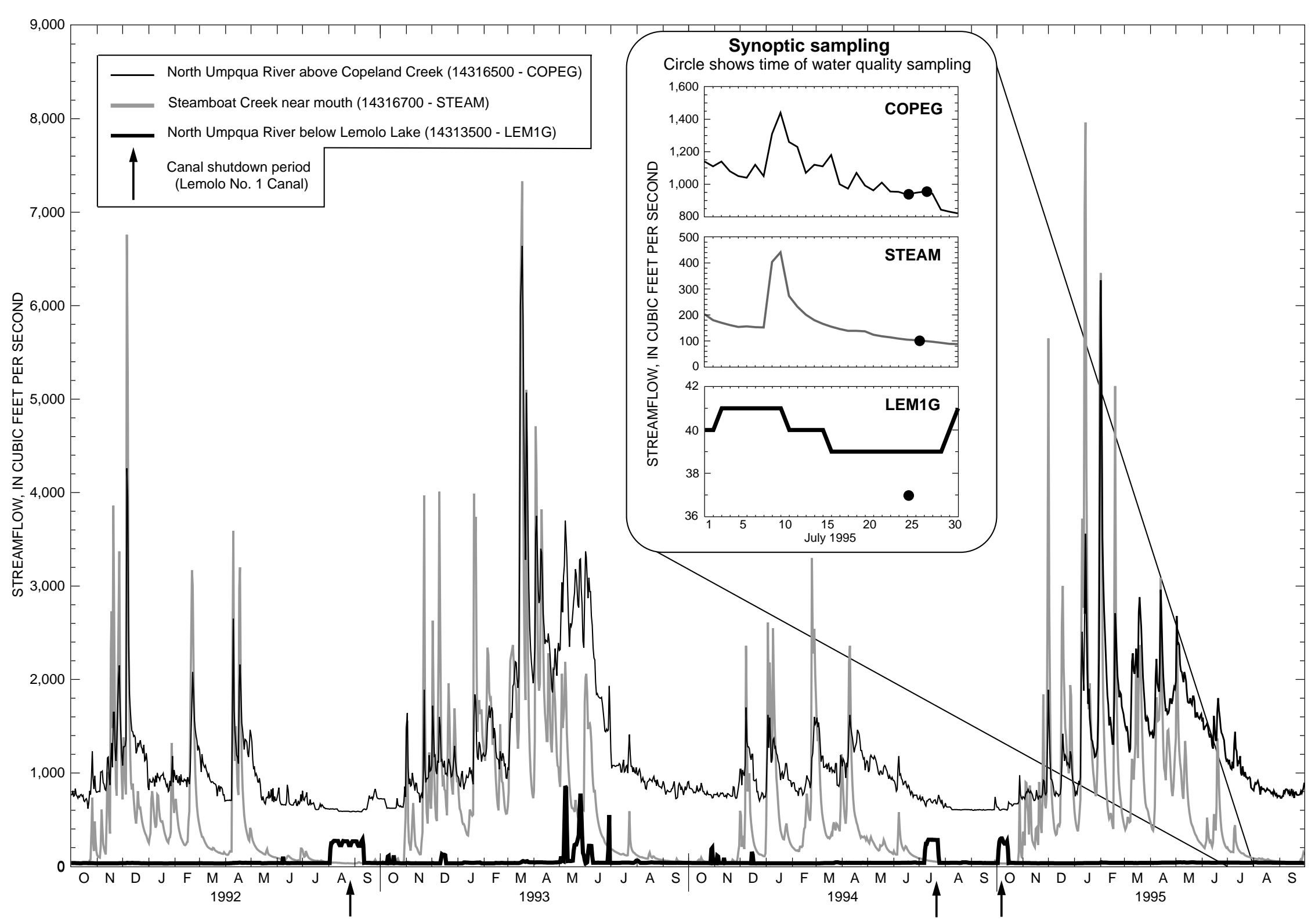

Figure 1. Daily mean discharge at three sites in the North Umpqua River Basin, Oregon, 1992-95. (Sampling in 1995 [see inset] was conducted from July 24-29.) 
Kirchner, 1975), and the potential for landslides is typically high on the steep slopes (PacifiCorp, 1995a, volume 3). The Western Cascades province includes most of the hydroproject developments (Lemolo No. 2, Toketee, Clearwater No. 2, Fish Creek, Slide Creek, and Soda Springs), the main stem North Umpqua River downstream to Glide (including the Wild and Scenic reach), the Steamboat Creek Basin, and most of the Little River watershed

Within the study area, the rocks of the Klamath Mountains are found only in the Little River watershed, comprising approximately $11 \%$ of that watershed primarily at low elevations.

Exposed rocks include granitic and sedimentary rocks, metamorphic volcanic and sedimentary rocks (composed of altered submarine volcanic flows, tuffs, flow-breccia, and agglomerates), and ultramafic rocks (composed of large masses of peridotite and dunite altered to serpentinite) (McFarland, 1983; U.S. Forest Service and Bureau of Land Management, 1995). Landslide potential in the granitic terrain of the Klamath Mountains is among the highest of any geologic unit within the Little River watershed (U.S. Forest Service and Bureau of Land Management, 1995). Permeability and recharge of the Klamath Mountain rocks are typically low, and well yields tend to be less than 10 gallons per minute (McFarland, 1983). Little information is available concerning the nutrient content of the soils or their tendency to export nutrients.

\section{Hydroproject Area}

The hydroproject area extends from the powerhouse at Soda Springs Reservoir (RM [river mile] 69.7) to the mouth of Lake Creek (RM 94.6), 10 miles downstream of Diamond Lake (RM 104.6), and to the North Umpqua River at RM 94.8 (Inlet Campground). The area also includes sections of the Clearwater River and Fish Creek (pl. 1). Constructed between 1947 and 1956, the hydroproject consists of eight developments that are used for generating electricity, 37.3 miles of waterways (canals and river channels) and penstocks. The total watershed area upstream from the dam at Soda Springs Reservoir is $470 \mathrm{mi}^{2}$ (PacifiCorp, 1995a, volume 3). Water-quality characteristics of Diamond Lake are described below because the lake contributes water and nutrients directly to the hydroproject area, however it is not a power generating facility and so is technically outside of the hydroproject area.

Flow patterns within the hydroproject area are complex. A schematic diagram (fig. 2) illustrates the highly engineered nature of streamflow upstream of Soda Springs. The intricacies of the flow patterns have been described in greater detail by PacifiCorp (1995a, volumes 2 and 3). Aspects of the flow pattern that are relevant to water quality within and downstream of the hydroproject area are summarized below and in table 1. Although daily flow records are kept by PacifiCorp for the bypass reaches and canals, continuous discharge data are available for only three sites in the hydroproject area. In most cases, the discharges indicated in table 1 are maximum design capacities; however, it is unlikely that they are achieved on a consistent basis. Similarly, the instream flow releases indicated in 1 are minimum flows for the natural stream channels that are included in the FERC operating permit. In most cases these flows are exceeded at the downstream ends of reaches because of accretion or tributary inflows.

With the exception of Lemolo Lake, which is drawn down during fall and winter to allow for flood storage, the reservoir system does not have a significant flood-control function. Retention times (calculated as the ratio of pool volume to outflow rate) in the reservoirs and forebays are relatively short, ranging from less than an hour at Slide Creek to 22 days at Lemolo Lake during summer (table 1). Nonetheless, the impoundments within the hydroproject area are the principle mechanisms controlling flow in the Wild and Scenic reach downstream of Soda Springs reservoir, particularly during the summer low-flow period.

Diamond Lake, which at over 3,000 acres is by far the largest water body in the study area (pl. 1, table 1), is a natural lake that is heavily used for recreation. The lake is classified as "eutrophic-polluted" and commonly experiences spring and summer blooms of diatoms and blue-green algae (Oregon Department of Environmental Quality, 1996). The lake is expected to remain in this condition for the foreseeable future, despite the diversion in 1971 of sewage from public recreation and fish cleaning facilities, because of the large amount of internal loading that contributes nutrients to the lake (Salinas and Larson, 1995). Lake Creek, the outflow from Diamond Lake, enters Lemolo Lake approximately 10 miles downstream. A sewage lagoon, built to handle the sewage diverted from Diamond Lake, discharges into Lake Creek well upstream of the mouth at Lemolo Lake. Lake Creek contributes approximately 30 to 50 cubic feet per second $\left(\mathrm{ft}^{3} / \mathrm{s}\right)$ of discharge to Lemolo Lake during the summer and has an annual mean flow of approximately $57 \mathrm{ft}^{3} / \mathrm{s}$ (Moffatt and others, 1990).

Lemolo Lake is the second-largest water body in the study area (approximately 400 acres) and the largest man-made impoundment. The North Umpqua River usually provides in excess of $290 \mathrm{ft}^{3} / \mathrm{s}$ inflow to Lemolo Lake during the summer months (PacifiCorp, 1995a, volume 3). Like Diamond Lake, Lemolo Lake is heavily used for recreation such as boating, fishing, swimming, and camping during the summer, and it experiences moderate summer algal blooms (Anabaena spp.). Retention times for water in the lake may increase from 15 to 22 days during low-flow periods in the summer (PacifiCorp, 1995a, volume 21 ). The lake is generally classified as mesotrophic but can at times be classified eutrophic on the basis of chlorophyll $a$ concentrations and $\mathrm{pH}$, which sometimes exceeds the State of Oregon standard of 8.5 during algal blooms (PacifiCorp, 1995a, volume 21; Oregon Department of Environmental Quality, 1996). On occasion, $\mathrm{pH}$ higher than 9.0 has been recorded (Bonoff and others, 1996), and chlorophyll $a$ has reached over $30 \mu \mathrm{g} / \mathrm{L}$ (micrograms per liter). Although Lemolo Lake stratifies thermally during the summer, the DO concentration has not been documented to be significantly depleted in the hypolimnion (PacifiCorp, 1995a, volume 21; Rinella, 1979; Johnson and others, 1985). The DO profile does, however, respond to summer algal blooms, with maximum concentrations often occurring in the thermocline (PacifiCorp, 1995a, volume 21; Bonoff and others, 1996).

The reach of the upper North Umpqua River below Lemolo Lake to Toketee Lake, and several reaches within the Clearwater and Fish Creek Basins have all been significantly altered from 


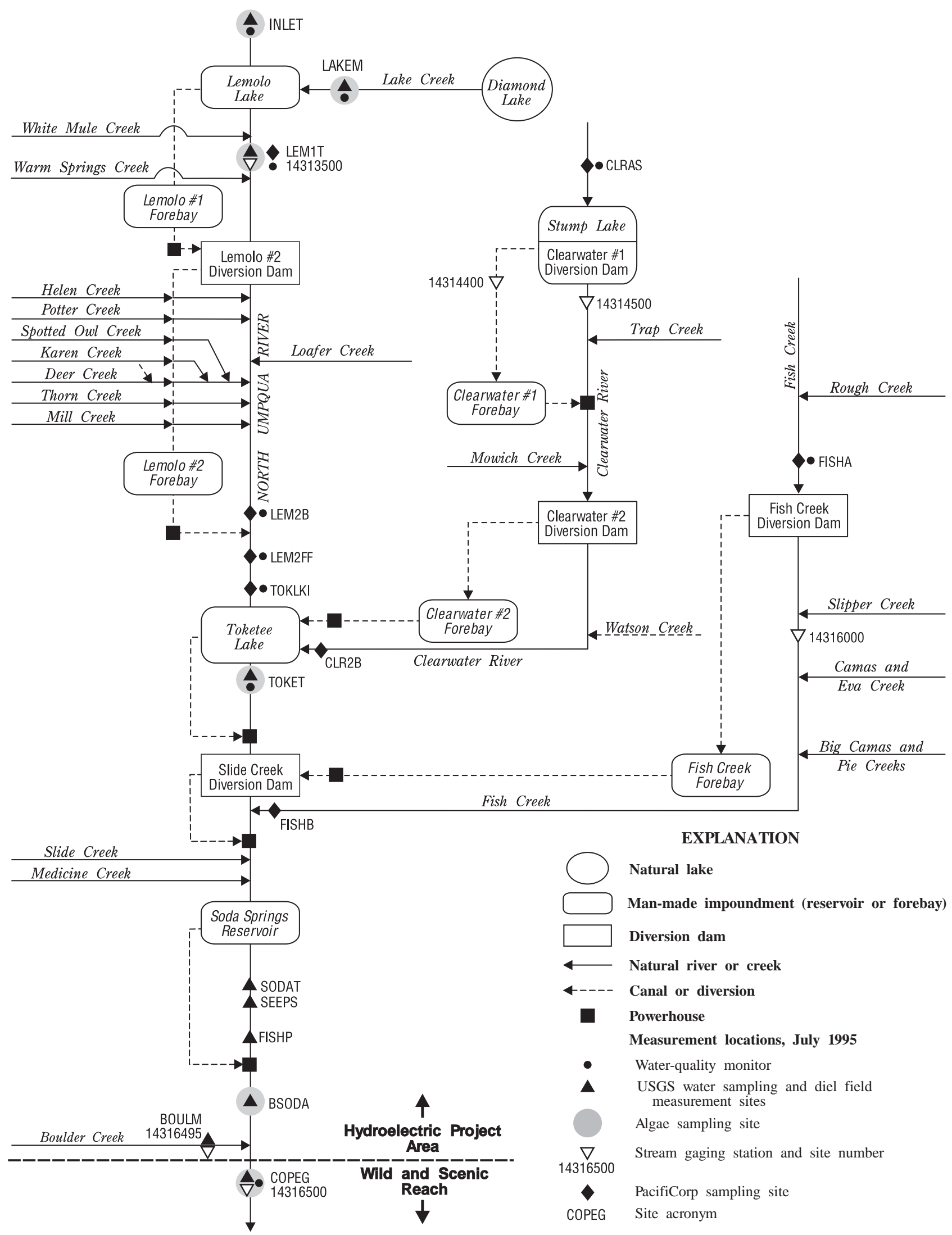

Figure 2. Schematic diagram showing impoundments, powerhouses, and diversions in the hydroelectric project area of the North Umpqua River Basin, Oregon. (Site acronyms are defined in glossary, on plate 1, and in table 5. Refer also to plate 1 for additional sites and distances throughout the study area.) 
Table 1. Hydrologic characteristics of impoundments within the hydroproject area of the North Umpqua River Basin, Oregon

[Data Sources: PacifiCorp, 1995a, Volumes 2, 3, and 11; Salinas and Larson, 1995; Johnson and others, 1985; Max, maximum; Min, minimum; ft³, cubic feet per second; --, not applicable; NA, not available; hrs, hours; <, less than]

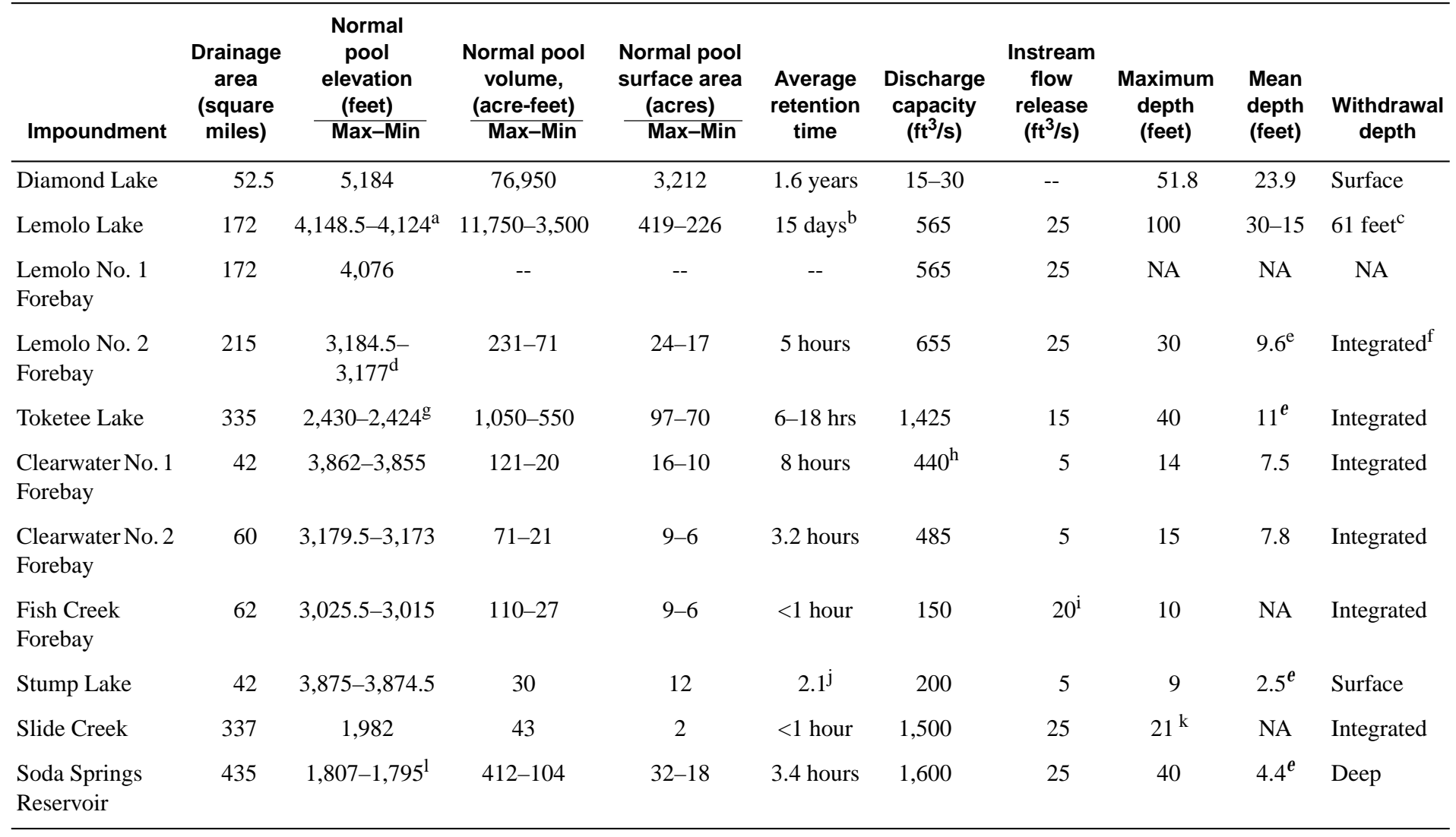

${ }^{a}$ Water surface elevation is lowered in the fall to provide storage area for winter and spring runoff from the drainage basin, and for extra power generation. Lemolo

Lake water levels are increased to near full pool in April and held near full pool throughout the summer.

${ }^{\mathrm{b}}$ Retention time can increase to 22 days during the summer low-flow period when the reservoir is at full pool elevation.

${ }^{\mathrm{c}}$ For power generation only. Water for instream flow is released from 100 feet.

${ }^{\mathrm{d}}$ Water level typically fluctuates 1.5 to 2.1 feet per day.

${ }^{\mathrm{e}}$ Calculated as (maximum pool volume) / (maximum pool surface area).

${ }^{\mathrm{f}}$ Water withdrawal is through large standpipe with inflow from various depths. Most of withdrawal is from bottom depths.

gWater level typically fluctuates up to 3 feet per day.

${ }^{\mathrm{h}}$ Median summer discharge is $146 \mathrm{ft}^{3} / \mathrm{s}$, from U.S. Geological Survey streamflow-gaging station 14314500.

${ }^{\mathrm{i}}$ Value given is for summertime flow (April 1 to Labor Day). Winter instream flow (Labor Day to March 31) is $10 \mathrm{ft}^{3} / \mathrm{s}$.

${ }^{\mathrm{j}}$ Calculated as (normal pool volume)/ pre-1983 average annual discharge (173 ft $3 / \mathrm{s}-$ U.S. Geological Survey, 1996).

${ }^{\mathrm{k}}$ Based on dam height.

${ }^{\mathrm{l}}$ Water level typically fluctuates 1 to 8 feet per day. 
their predevelopment hydrological states. Due to the diversion of a large proportion of flow for power generation, the original stream channels do not experience the same magnitude or timing of flows as they did prior to the construction of the hydroelectric facilities, and flows in the bypass reaches (previous natural stream channels) tend to be more stable than before regulation. In addition, the construction of diversion dams, canals, and forebays that divert water to power generation has created new and different types of aquatic habitats. Several aspects of waterquality and biological processes, such as nutrient processing and food-web dynamics, can change according to hydrological conditions and may be affected by these manipulations.

Water is withdrawn from Lemolo Lake at depths of 61 feet (at full pool elevation, table 1) for power generation and 100 feet for instream flow releases. Two series of canals, bypass reaches, and powerhouses transmit this and inflowing tributary water from Lemolo Lake to Toketee Lake. Return flow from the Lemolo No. 2 powerhouse enters the North Umpqua River 0.9 miles upstream from Toketee Lake. Although this short reach is characterized as a full-flow reach of the river, daily flows may vary by $400 \mathrm{ft}^{3} / \mathrm{s}$ on roughly one-half of the days. This is in response to power generation to meet energy system demands at the Lemolo No. 2 powerhouse, often resulting in relatively low flows during nighttime and on weekends and relatively high flows during daytime (PacifiCorp, 1995a, volume 3). The Lemolo No. 2 forebay, which holds water in preparation for power generation, is essentially a pond that itself is subject to water-quality concerns such as elevated $\mathrm{pH}$ (>8.5 units), decreased DO ( $<90 \%$ saturation), and both phytoplankton (floating algae) and periphyton (attached algae). Algal blooms and periphytic algae growing in the canal have been responsible for exceedances of the State standards for DO and $\mathrm{pH}$ that have occurred occasionally in the forebay, primarily during the 2-week annual maintenance period when canal flows were low (PacifiCorp, 1995a, volume 21). Water levels within the forebay may fluctuate up to 7 feet per day, as flow through the powerhouse changes to meet energy demands (table 1). The forebay also has the highest rate of trout growth in the hydroproject area, even supporting a recreational fishery (PacifiCorp, 1995a, volume 4), a fact which underlines the need to maintain State standards for $\mathrm{DO}, \mathrm{pH}$, and water temperature within the forebay.

The upper North Umpqua and Clearwater Rivers converge at Toketee Lake (fig. 2). With a high volume outflow to the Toketee Lake powerhouse, the lake has a retention time of only 6-18 hours (table 1). Because of the short retention time, the lakegenerally classified as oligotrophic-typically does not stratify thermally (PacifiCorp, 1995a, volume 21). However, there is an indication of incomplete horizontal mixing in Toketee Lake: cool water from the Clearwater River inflow apparently tends to circulate preferentially along the southern shore of the lake in the vicinity of the lake's spillway and enter the Toketee bypass reach. In contrast, water exiting the lake for power generation through the diversion structure probably originates as warmer water from the upstream end of the lake and derives largely from the upper North Umpqua River (PacifiCorp, 1995a, volume 21). This short circuiting has additional implications for water quality in the river below Toketee Lake, because the Clearwater River often has phosphorus concentrations that are relatively high compared to other streams in the North Umpqua River Basin. Indeed, heavy periphytic algal growths have been noted below the Clearwater No. 2 powerhouse and in the bypass reach immediately downstream of the Toketee Lake dam.

One possible nutrient point source exists in the hydroproject area, and it may influence nutrient concentrations in and below Toketee Lake. Written correspondence between the U.S. Forest Service and PacifiCorp in 1971 (Dallas Hughes, U.S.Forest Service Memo to Pacific Power and Light, written commun., 1971) indicated that there was historically an input of sewage leaching from the U.S. Forest Service's Toketee Ranger Station and housing complexes beside the lake operated by PacifiCorp. Abundant algal blooms in Toketee Lake at the time were attributed to eutrophication by nutrients in this sewage. Although some of the sewage systems at Toketee have apparently been replaced since 1971, the extent of the cleanup of the old system is unknown; some of the housing units above the reservoir (and above a seep having greater than 1 milligram per liter of nitrate-nitrogen) are still on original systems, and no comprehensive review or resampling of the original seeps has been performed (Mikeal Jones, U.S. Forest Service, written commun., 1997).

The Clearwater River Basin, which has a significant ground-water component in its upper reaches, includes one small man-made lake (Stump Lake) and two power diversions that pass water through the Clearwater No. 1 and No. 2 forebays. Minimum flow releases are $5 \mathrm{ft}^{3} / \mathrm{s}$ for each of the instream reaches, with accretion adding an additional $60-80 \mathrm{ft}^{3} / \mathrm{s}$ to the Clearwater No. 2 bypass reach during summer low flow (PacifiCorp, 1995a, volume 3). The outflow channel directly below Stump Lake (Clearwater No. 1 bypass reach) is at times covered with long strands of filamentous periphytic algae (The Register Guard, Eugene, Oregon, June 28, 1994, p. 1D). Concentrations of DO below the State standard have occasionally been noted throughout the Clearwater River Basin, both within the bypass reaches and natural stream channels as well as the forebays (PacifiCorp, 1995a, volume 21).

The return flow from the Toketee Lake powerhouse enters the North Umpqua River just upstream of Slide Creek Reservoir, a small impoundment that also serves as the outflow location for the Fish Creek powerhouse (fig. 2). Water from the Fish Creek bypass reach (30 to $60 \mathrm{ft}^{3} / \mathrm{s}$ during summer) enters the river through its natural channel downstream of the Slide Creek Reservoir, as does Slide Creek itself. With the addition of water from the Fish Creek bypass reach, and the return flow from the Slide Creek powerhouse, the river essentially attains the full volume that eventually enters the Wild and Scenic reach downstream. The only additional water sources are Medicine Creek, Slide Creek, and Soda Springs, which contribute less than $5 \mathrm{ft}^{3} / \mathrm{s}$ during summer.

Soda Springs Reservoir is the lowermost reservoir in the hydroproject, and its outflow through the Soda Springs powerhouse is the primary source of water for the Wild and Scenic reach, particularly during the summer. The reservoir is the third largest man-made impoundment within the hydroproject area, and it occasionally experiences phytoplankton blooms. Like Toketee Lake, however, the epilimnion of the reservoir is generally characterized as oligotrophic on the basis of calculated values of Carlson's Trophic State Index (PacifiCorp, 1995a, 
volume 3). Summer discharge from the reservoir, which is mostly from the deeper parts of the water column (table 1), is primarily through the Soda Springs powerhouse, entering the North Umpqua River 0.5 miles downstream at an average flow of approximately $1,150 \mathrm{ft}^{3} / \mathrm{s}$ (Moffatt and others, 1990). A fishholding facility located between the dam and the powerhouse, which draws water from the penstock carrying water to the Soda Springs powerhouse, supplies 7 of the $25 \mathrm{ft}^{3} / \mathrm{s}$ released to the bypass reach during summer. With a maximum design flow of $1,600 \mathrm{ft}^{3} / \mathrm{s}$ in the penstock, spills of water over the dam in excess of $25 \mathrm{ft}^{3} / \mathrm{s}$ are much more common in the winter and spring when peak reservoir releases may commonly exceed $2,000 \mathrm{ft}^{3} / \mathrm{s}$. Maintenance of the powerhouse and penstocks also can cause large flow releases through the bypass reach, although maintenance is typically done in March during periods when excess water is already being released from the reservoir.

Currently there are no fish passage facilities at the Soda Springs Dam. The Soda Springs bypass reach is therefore the farthest upstream in the North Umpqua River that anadromous or resident fish are able to migrate. There are resident (native and hatchery) fish populations in streams within the hydroproject area, but their upstream migration is blocked by natural barriers as well as the various dams. In its FERC license application, PacifiCorp is proposing to study the addition of fish passage facilities to Soda Springs Reservoir to enhance production of anadromous fish in the reach between Soda Springs Reservoir and the Slide Creek Dam. No additional fish passage is proposed upstream of Slide Creek because the habitat is not deemed suitable for anadromous fish relative to the cost of construction (PacifiCorp, 1995a, volume 4).

\section{Wild and Scenic Reach}

The 32 miles of the Wild and Scenic reach from Boulder Creek to Rock Creek (RMs 67.9-35.7, pl. 1), support many beneficial uses, including withdrawals for water supply, irrigation, and livestock; anadromous fish passage, rearing, and spawning; habitat for resident fish and aquatic life; fishing; and water-contact recreation (Oregon Administrative Rules, Chapter 340, Division 41, Rule Number 340-41-282, 1994). The river has been famous for its scenic qualities and for fly fishing, particularly for wild steelhead. Yet despite the beauty and the many recreational opportunities within the Wild and Scenic reach, the river is no longer a completely natural, undisturbed system because of the flow manipulations within the study area and extensive land management activities (including timber harvesting and road building) in the basin.

Most of the water in the Wild and Scenic reach during the summer low-flow months of August and September (approximately 700-900 ft 3 /s) comes from Soda Springs Reservoir. Steamboat Creek, Rock Creek, and the Little River add about 100,80 , and $60 \mathrm{ft}^{3} / \mathrm{s}$, respectively, and several other small tributaries add another $50 \mathrm{ft}^{3} / \mathrm{s}$. The river has a relatively high gradient from Soda Springs to Rock Creek (average 5 feet per 1,000 feet; U.S. Geological Survey, 1915), and is frequently interspersed with riffles, glides, and runs. Two significant drops mark the downstream terminus of the Wild and Scenic reach near Rock Creek, and the Little River joins the North Umpqua River
6.6 miles farther downstream. Although the river is bounded by relatively steep canyon hillsides, State Highway 138 follows the course of the river for the entire length of the Wild and Scenic reach.

Throughout much of the Wild and Scenic reach the river is characterized by bedrock channels with ledges and deep pools, interspersed with cobbles and boulders (PacifiCorp, 1995a, volume 4). This type of riverbed, or substrate, is very stable and offers a solid surface for attachment by periphytic algae, helping them resist scour during high-flow periods. Gravel, which is critical for spawning habitat, tends to provide a less stable base for attachment by periphytic algae because it is more susceptible to scour and movement. However, there is little gravel in the 2.2-mile reach between Soda Springs Reservoir and Boulder Creek, including the Soda Springs bypass reach, because of upstream interception of sediments by the reservoirs (PacifiCorp, 1995a, volume 4). As a result, tributaries are the principal sources of gravel in the Wild and Scenic reach upstream of Steamboat Creek. Indeed, the area of riverbed covered by gravel becomes increasingly larger downstream of Boulder Creek and subsequently Copeland Creek, according to a 1993 survey (PacifiCorp, 1995a, volume 4). In order to provide more gravel for spawning habitat, PacifiCorp proposes to add and maintain additional gravel deposits in the Soda Springs bypass reach and to construct a stockpile of gravel along the Boulder Creek access road, downstream of the Soda Springs powerhouse, that would be redistributed in a natural manner during high-flow periods. Although intended to provide habitat for spawning, these measures would also help increase scour of algae, and provide habitat for benthic organisms that contribute to processing of organic detritus.

\section{Steamboat Creek}

The Steamboat Creek Basin, which is the principal spawning ground of the North Umpqua's famous run of native steelhead trout and other species of trout and salmon, is $227 \mathrm{mi}^{2}$ in area and joins the North Umpqua at RM 53.0. Because of its importance as spawning habitat, the basin has been closed to angling since 1932 (Holaday, 1992). The area includes the Canton Creek subbasin (Steamboat Creek RM 0.51), which contains a large amount of private timber land, and the Big Bend Creek subbasin (Steamboat Creek RM 11.8), which is National Forest land. Also located in the upper reaches are several tributaries in which mining has occurred in the past, and in which there are pending claims for additional future mining.

Steamboat Creek has had a long history of problems with high water temperatures. Although Holaday (1992) showed that there were decreasing annual maximum water temperatures in Steamboat Creek during 1969-90, in conjunction with regrowth of riparian cover in previously logged areas, he also determined that maximum stream temperatures in the lower reaches of the creek had been high since data collection began in the late 1950's. Big Bend Creek, with its large roadless area, high summer discharge, and plentiful riparian cover, provides a large amount of relatively cool water (annual maximum temperature approximately $19^{\circ} \mathrm{C}$ (degrees Celsius) $\left(66^{\circ} \mathrm{F}\right)$ to Steamboat Creek. As a result, steelhead are known to hold in a deep pool 
below the mouth of Big Bend Creek in late summer and fall until water temperatures in upper Steamboat Creek drop sufficiently for them to migrate further upstream. Likewise, the maximum water temperatures approaching $25^{\circ} \mathrm{C}\left(77^{\circ} \mathrm{F}\right)$ or greater near the mouth of Steamboat Creek (Holaday, 1992) may be one reason that steelhead hold temporarily in the North Umpqua River near the mouth of Steamboat Creek in the summer.

Given the importance of Steamboat Creek as steelhead habitat, and its high water temperatures, the potential impact of increased periphytic algal growth on water quality in the creek is high. High algal productivity could induce important diel changes in $\mathrm{pH}$ and DO and could cause deleterious effects, such as high $\mathrm{pH}$, low DO, or shifts in the aquatic food webs and community structure. Indeed, $\mathrm{pH}$ values greater than the State standard of $8.5 \mathrm{pH}$ units, and DO below the State standard of $90 \%$ saturation have been documented in Steamboat Creek in the past (PacifiCorp, 1995a, volume 21; Powell, 1997).

\section{Little River Watershed}

The $206 \mathrm{mi}^{2}$ Little River watershed, which lies outside of the Wild and Scenic reach of the North Umpqua River, is heavily managed for timber; almost $60 \%$ of the watershed had been harvested by 1995 . Designated beneficial uses, which are similar to those for the North Umpqua River in general, include withdrawals for water supply, irrigation, and livestock; anadromous fish passage, rearing, and spawning; habitat for resident fish and aquatic life; fishing; and water-contact recreation (Oregon Administrative Rules, Chapter 340, Division 41, Rule Number 340-41-282, 1994). The basin is also heavily used for camping and hunting.

Public land in the Little River watershed was designated as an Adaptive Management Area (AMA), 1 of 10 so designated in the President's Northwest Forest Plan (U.S. Forest Service and Bureau of Land Management, 1994). As a requirement of this designation the U.S. Forest Service completed a watershed analysis for the Little River in September 1995 (U.S. Forest Service and Bureau of Land Management, 1995). A special area of focus for the Little River AMA is the development and implementation of methods to integrate intensive timber production with restoration and maintenance of high-quality riparian habitat.

The Little River joins the North Umpqua River near the town of Glide (RM 29.1). The Little River has many of the same water-quality problems as Steamboat Creek, including periodic high $\mathrm{pH}$ due to algal productivity and elevated water temperatures, which contribute to pressures on threatened or endangered fish species. Maximum $\mathrm{pH}$ values in the Little River watershed have been documented as high as $9.1 \mathrm{pH}$ units, and daily maximum $\mathrm{pH}$ has been positively correlated with the upstream area of timber harvested (Powell, 1995; 1997).

\section{Water-Quality Issues and Aquatic Ecosystem Concepts}

The following section presents a description of Oregon's water-quality standards that are relevant to the North Umpqua River Basin, as well as a literature review highlighting some of the water-quality issues facing natural-resource managers in the basin. Because of the fundamental controls that hydrological systems exert on the biological processes in a stream, flow manipulations from hydropower and forestry activities can have potentially far-reaching consequences. This section of the report provides a discussion of issues that are important in the basin and a basic description of stream processes related to nutrients, benthic algae (periphyton), and aquatic food webs in the basin. References are provided for those interested in further pursuing the concepts.

Current driving forces for many water-quality investigations in western Oregon streams, including the North Umpqua River, include concern for anadromous fish and the societal pressures associated with endangered species. In this context, the term "water quality" broadly encompasses questions about physical habitat, ecological processes, streamflow, chemical composition of the water, and complex interactions of these factors. As concerns over declining stocks of fish have grown, additional emphasis has been placed on management of the aquatic resource and its potential impact on the river's ecosystem, including benthic algae as the basis for river food webs.

\section{Water-Quality Standards}

Periphyton in streams in western Oregon commonly cause diel fluctuations in $\mathrm{DO}$ and $\mathrm{pH}$ through photosynthesis and respiration (Oregon Department of Environmental Quality, 1995; Tanner and Anderson, 1996), and the resulting low concentrations of DO or high $\mathrm{pH}$ may create problems for aquatic animals or cause other nuisance conditions (Welch and others, 1989). Excessive growths of algae, which have been observed at some locations in the North Umpqua River Basin (Eugene Register Guard, June 28, 1994, p. 1D), are often fueled by nutrient inputs (especially nitrogen and phosphorus) to streams. Because streams in the Cascade Range are commonly low in nitrogen (Triska and others, 1983; Leland, 1995; Bakke and Pyles, 1997), it is important to characterize nitrogen and phosphorus sources in order to manage algal growth. Other important factors regulating the buildup of periphyton biomass include nutrient release and consumption within the benthic community, otherwise known as recycling (Elwood and others, 1981; Paul and others, 1991, Mulholland, 1996), interactions between periphyton and invertebrate grazers (Steinman, 1996), type and stability of substrate for attachment, and disturbance and scour resulting from changes in discharge (Horner and others, 1983; Wooten and others, 1996). As the primary source for inputs of external energy for aquatic food webs (DeAngellis, 1992), changes in algal growth patterns can potentially have a significant effect on higher trophic levels. Because of these considerations, knowledge about nutrient inputs, algal growth and resulting influences on $\mathrm{pH}$ and $\mathrm{DO}$, and the role of forestry and hydropower is critically important to understanding the factors influencing water quality in the North Umpqua River Basin.

Concurrent with these concerns, there is a widespread emphasis on regulations resulting from the Clean Water Act, including the requirement for States to set water-quality standards and establish Total Maximum Daily Loads (TMDLs) 
on rivers in which those standards are not being met. This has fostered additional focus on measurement of basic stream characteristics such as water temperature, $\mathrm{DO}$, and $\mathrm{pH}$. The State of Oregon has developed water temperature and DO standards that are specific for geographic location, the water body itself, and the aquatic biota found there. For the North Umpqua River Basin, the timing of spawning for resident and anadromous fish determines the temperature and DO standards in effect (table 2). In any year, there are either resident or anadromous fish spawning at any time between mid-September and mid-May, but no fish spawning from mid-May to mid-September (Dave Loomis, Oregon Department of Fish and Wildlife, oral commun., 1997). Standards for water temperature and DO, therefore, are less stringent for the summer months (mid-May to midSeptember) than during the rest of the year. Although the standards changed in 1996, the seasonal aspect was in effect before 1996 as well. In this report, temperature and DO are primarily compared with standards in effect during 1995 and previously. Some references are also made to the conditions relative to standards enacted in 1996.

Because of the history of elevated temperatures in parts of the North Umpqua River Basin, particularly Steamboat Creek, high water temperatures are an important concern in the basin. Elevated water temperatures can have detrimental effects on salmonid populations by causing changes in the food resources and by direct effects on the metabolism, development, and activity of the fish. The optimal temperature range for steelhead is $10-13^{\circ} \mathrm{C}\left(50-55^{\circ} \mathrm{F}\right)$, and temperatures below $10^{\circ} \mathrm{C}$ are most desirable for spawning. Temperatures above $24^{\circ} \mathrm{C}\left(75^{\circ} \mathrm{F}\right)$ can be lethal (Bjornn and Reiser, 1991; Jobling, 1981). There was no specific numerical standard for temperature in effect during July
1995. The summer standard was based on minimizing any increase in temperature due to human activities at ambient temperatures above $18.9^{\circ} \mathrm{C}\left(66^{\circ} \mathrm{F}\right)$. The revised standard does not allow the average 7-day daily maximum temperature to exceed $17.8^{\circ} \mathrm{C}\left(64^{\circ} \mathrm{F}\right)$. Exceptions to these standards could be allowed under basinwide surface-water temperature management plans, subject to approval by the Oregon Department of Environmental Quality (Oregon Department of Environmental Quality, 1996, Oregon listing criteria for Section 303(d) list).

The State water-quality standard for DO, in effect during July 1995 and previously, was based on the percent saturation of DO in water, and varied depending on the time of year as described previously and shown in table 2 . For the summer periods encompassed in this report, the $90 \%$ saturation standard applied. With the revision of the standard in 1996, the current DO standard for summer months in the North Umpqua River is $8 \mathrm{mg} / \mathrm{L}$ (as a 30-day mean minimum concentration). At some of the upper elevations of the watershed (upstream of Soda Springs Reservoir), the concentration of DO at saturation can be relatively close to this concentration because of lowered barometric pressure, and can therefore exceed the standard as a result of small fluctuations. Regardless, the goal of protecting the most sensitive designated beneficial use dictates that the numeric standard would still apply as long as it is physically possible to achieve that value (Lynne Kennedy, Oregon Department of Environmental Quality, written commun., 1997).

The State water-quality standards for fresh waters specify a $\mathrm{pH}$ within the range of 6.5-8.5. As of January 1996, however, an exception is made for artificially impounded waters if the Oregon Department of Environmental Quality determines that all practicable measures have been taken to bring the $\mathrm{pH}$ into

Table 2. State of Oregon water-quality standards for $\mathrm{pH}$, water temperature, and dissolved oxygen for the North Umpqua River Basin, Oregon

[Source: Oregon Administrative Rules, Attachment A to Chapter 340, Division 41, 1996. mg/L, milligrams per liter; >, greater than; ${ }^{\circ} \mathrm{C}$, degrees Celsius; ${ }^{\circ} \mathrm{F}$, degrees Fahrenheit; \%, percent]

\begin{tabular}{|c|c|c|c|c|}
\hline \multirow[b]{2}{*}{ Constituent } & \multicolumn{2}{|c|}{$\begin{array}{l}\text { Previous standard } \\
\text { (prior to 1996) }\end{array}$} & \multicolumn{2}{|c|}{$\begin{array}{c}\text { Revised standard } \\
\text { (implemented in 1996) }\end{array}$} \\
\hline & $\begin{array}{c}\text { Non-spawning } \\
\text { periods } \\
\text { (mid-May to } \\
\text { mid-September) }\end{array}$ & $\begin{array}{c}\text { Spawning } \\
\text { periods } \\
\text { (mid-September to } \\
\text { mid-May) }\end{array}$ & $\begin{array}{c}\text { Non-spawning } \\
\text { periods } \\
\text { (mid-May to } \\
\text { mid-September) }\end{array}$ & $\begin{array}{c}\text { Spawning } \\
\text { periods } \\
\text { (mid-September to } \\
\text { mid-May) }\end{array}$ \\
\hline $\mathrm{pH}$ (units) & $6.5-8.5$ & $6.5-8.5$ & $6.5-8.5^{\mathrm{a}}$ & $6.5-8.5^{\mathrm{a}}$ \\
\hline Water temperature $(\mathrm{T}),{ }^{\circ} \mathrm{C}\left({ }^{\circ} \mathrm{F}\right)$ & $\begin{array}{l}\text { No change when } \\
\mathrm{T}>18.9^{\circ} \mathrm{C}\left(66^{\circ} \mathrm{F}\right)\end{array}$ & $\begin{array}{l}\text { No change when } \\
\mathrm{T}>14.4^{\circ} \mathrm{C}\left(58^{\circ} \mathrm{F}\right)\end{array}$ & $\begin{array}{c}17.8^{\circ} \mathrm{C} \\
\left(64.0^{\circ} \mathrm{F}\right)^{\mathrm{b}}\end{array}$ & $\begin{array}{l}12.8^{\circ} \mathrm{C} \\
\left(55^{\circ} \mathrm{F}\right)^{\mathrm{b}}\end{array}$ \\
\hline Dissolved oxygen (DO), mg/L & $90 \%$ of saturation & $95 \%$ of saturation & $8.0^{\mathrm{c}, \mathrm{d}}, 6.5^{\mathrm{e}}, 6.0^{\mathrm{f}}$ & $11.0^{\mathrm{g}, \mathrm{h}}, 9.0^{\mathrm{h}, \mathrm{i}}$ \\
\hline
\end{tabular}

${ }^{a}$ Waters impounded by dams existing on January 1, 1996, are exempted if the Oregon Department of Environmental Quality determines that the exceedance would not occur without the impoundment and that all practicable measures have been taken to bring the $\mathrm{pH}$ in the impounded water into compliance.

${ }^{\mathrm{b}}$ Based on 7-day average of daily maximum temperatures.

${ }^{\mathrm{c}}$ Based on 30-day mean minimum concentration.

${ }^{\mathrm{d}}$ If conditions of barometric pressure, altitude, and temperature preclude achievement of the indicated concentration, then the $90 \%$ saturation standard applies.

${ }^{\mathrm{e}}$ Based on 7-day minimum mean concentration.

${ }^{\mathrm{f}}$ Absolute minimum.

${ }^{\mathrm{g}}$ Absolute minimum, if intergravel DO is less than $8.0 \mathrm{mg} / \mathrm{L}$.

${ }^{\mathrm{h}}$ If conditions of barometric pressure, altitude, and temperature preclude achievement of the indicated concentration, then the $95 \%$ saturation standard applies.

${ }^{\mathrm{i}}$ If intergravel DO is greater than or equal to $8.0 \mathrm{mg} / \mathrm{L}$. 
compliance. This exception apparently applies to waters in streams below impoundments as well, if the impoundments are deemed to be the source of the high $\mathrm{pH}$ water. This exception applies to impoundments within the hydroproject in the North Umpqua River Basin.

\section{Benthic Algae}

A key issue in the North Umpqua River Basin is the perception that benthic algae (periphyton) are overly abundant. Locally, important concerns associated with abundant algal growth include: the impacts of periphyton on $\mathrm{DO}$ and $\mathrm{pH}$; nutrient dynamics (limitation, sources, and transport); changes in algal community structure and biomass; and the impacts of such changes on higher trophic levels (food webs). An understanding of the degree to which resource-management activities in the basin (particularly forestry and hydropower generation) affect these processes can help managers minimize negative impacts of the activities.

Dissolved oxygen and $\mathbf{p H}-$ Algal metabolism can significantly affect early morning and late afternoon concentrations of DO and pH (Odum, 1956; Welch, 1992). Photosynthesis, a light-driven process (Graham and others, 1982; Wooton and Power, 1993), consumes carbon dioxide $\left(\mathrm{CO}_{2}\right)$ and produces oxygen (eq. 1). Respiration by aquatic plants and animals, which occurs at all times, consumes oxygen and produces $\mathrm{CO}_{2}$. Diel changes in $\mathrm{pH}$ are caused by shifts in the carbonate equilibrium (eq. 2) as the algae utilize $\mathrm{CO}_{2}$ (or bicarbonate, $\mathrm{HCO}_{3}{ }^{-}$) during photosynthesis (Wetzel, 1983) faster than atmospheric inputs can equilibrate. Streams with significant periphyton communities often have supersaturated DO concentrations and high $\mathrm{pH}$ values late in the day and minimum DO and $\mathrm{pH}$ values in the early morning (for examples, see Kuwabara, 1992, or Tanner and Anderson, 1996). However, the solubility of DO is inversely proportional to the water temperature, which rises in response to solar radiation and thereby decreases DO solubility during daylight hours, and is also impacted by physical reaeration. In effect, stream temperature, reaeration, photosynthesis, and respiration compete for control of DO in streams. The effects of repeated, short-term diel fluctuations in $\mathrm{DO}$ and $\mathrm{pH}$ on aquatic life are largely unknown.

$$
\begin{gathered}
6 \mathrm{CO}_{2}+6 \mathrm{H}_{2} \mathrm{O} \underset{\text { Respiration }}{\frac{\text { Photosynthesis }}{2} \mathrm{C}_{6} \mathrm{H}_{12} \mathrm{O}_{6}+6 \mathrm{O}_{2}} \\
\mathrm{CO}_{2}+\mathrm{H}_{2} \mathrm{O} \longrightarrow \mathrm{HCO}_{3}^{-}+\mathrm{H}^{+} \longrightarrow \mathrm{CO}_{3}^{2-}+2 \mathrm{H}^{+}
\end{gathered}
$$

Nutrient sources for benthic communities-A repeated cycle of nutrient release, uptake, and release (recycling) within an algal mat may mask the true transport or input of nutrients in a stream (Elwood and others, 1981; Paul and others, 1991; Mullholland, 1996), retaining nutrients in biomass that are subsequently released through excretion, senescence (decay), remineralization, and scouring (Mulholland, 1992). These processes place increasing importance on dissolved organic and particulate nutrient forms when concentrations of inorganic nutrients are low (Meyer and Likens, 1979), and could explain the importance of such nutrient forms in the North Umpqua River. Nonpoint nutrient inputs, coming from diverse sources such as overland flow, ground-water, or hyporheic (interstitial, near stream) flow (Triska, Duff, Avanzino, 1989) could be particularly masked because they can be incorporated directly into algal tissue and recycled downstream without ever becoming entrained into the part of the water column that is usually sampled.

During periods of high productivity, downstream depletion of inorganic nutrients increases the importance of atmospheric, organic, or particle bound nutrients (Mulholland, 1992). Nitrogen fixation by benthic blue-green algae can be a significant source of nitrogen (Wetzel, 1983; Dodds and others, 1995). As much as $40 \%$ of the total nitrogen assimilated by blue-green algae is released extracellularly by these organisms and is available to other biota (Fogg and others, 1973). Some blue-green algae (for example, Nostoc sp. and Rivularia sp., both found in the North Umpqua River) possess specialized structures called heterocysts, which contain the nitrogen-fixation enzyme nitrogenase. Heterocysts protect nitrogenase against the ill effects of oxygen, a nitrogen-fixation inhibitor (Fogg and others, 1973). Another group of algae associated with nitrogen fixation includes diatoms of the family Epithemiaceae. These algae, which often contain endosymbiotic blue-green algae as inclusions that can provide nitrogen through fixation (Floener and Bothe, 1980), are less efficient at nitrogen fixation than heterocystous nitrogen fixers. As will be seen, epithemiacean diatoms, including the genera Rhopalodia and Epithemia, are important components in the algal communities at many locations in the North Umpqua River Basin.

The relationship between colonies of Nostoc, (a colonial, nitrogen fixing blue-green alga) and larvae of the chironomid midge Cricotopus nostocicola has been well studied (Brock, 1960; Dodds and Marra, 1989). The midge, which inhabits the core of the algal colony's structure, grazes the algal host and obtains refuge from other predators, while the Nostoc colonies benefit as the midge helps secure the colony to the substrate with silk (Dodds and Marra, 1989). Nostoc colonies containing midges also had higher rates of photosynthesis than colonies without midges (Ward and others, 1985), apparently due to morphological changes in the colonies: colonies containing midges protrude into the current farther, which increases the diffusion rates of carbon dioxide and oxygen. The occurrence of Nostoc spongiiforme hosting an unidentified chironomid midge larva was observed frequently in the North Umpqua River during this study, and this association could help supply nitrogen to the river.

During late successional stages (when nutrients can become limiting inside benthic algal mats), periphyton (particularly filamentous green algae) undergo a senescence process whereby the basal cells of the mat decay (Biggs, 1996). This separation of the mat from the substrate, termed autogenic sloughing, can represent an important transport of nutrients in a river system. Rates of nutrient remineralization following autogenic sloughing vary considerably and are determined by water temperature and other factors controlling heterotrophic processing (DO concentrations among them). The release of dissolved organic 
compounds containing high concentrations of nitrogen has been documented, even from healthy cells (Bjornsen, 1988), and utilization by heterotrophic organisms (including algae) has been shown (Hellebust and Lewin, 1977; Rogers and Gallon, 1988; Bourdier and others, 1989; Schollett and others, 1996; Cuffney and others, 1997). Greene (1996) demonstrated that dissolved organic nitrogen compounds from forested tributaries to the South Umpqua River were biologically available to algae. The importance of organic nitrogen in the algal ecology of the North Umpqua River is examined later in this report (see p. 28, 33-36).

Algae in river food webs-Periphyton provide an interface between abiotic resources and the food web, converting nutrients and energy into organic biomass. The efficiency at which energy is transferred from one trophic level to another (in the North Umpqua River, from algae to invertebrates and ultimately to fish) is a function of several factors including the "edibility" of the algae and the types of herbivores present (DeAngelis, 1992). In general, diatoms (such as those reported in this study) are preferred over filamentous green or blue-green algae as a food source (Power and others, 1988; Stevenson, 1997), which may be due to the production of a protective sheath and (or) toxic compounds by the blue-green algae (Fogg and others, 1973). Several hypotheses have been proposed to describe top-down (predator/grazer controlled) versus bottom-up (algal bacteria controlled) influences on benthic food webs (for a review see Lamberti, 1996) but much debate continues as to which influence is strongest.

Food webs in regulated rivers like the North Umpqua may function differently from those in natural systems because dams prevent or reduce the frequency of scouring floods that may seriously affect river food webs. For example, Wooton and others (1996) showed that the abundance of larvae of Dicosmoecus D. gilvipes, a large herbivorous caddis fly, increased in the absence of floods. They proposed that although $D$. gilvipes is susceptible to the scouring action of rolling cobbles and boulders at high flows, its armored stone case made it resistant to most fish and invertebrate predators and it thereby flourished when those floods did not occur. Walton and others (1995) showed that grazing by gilvipes caused a shift in the algal community toward filamentous blue-green algae, possibly due to the reduced food quality of these mucilaginous forms (Mary Power, University of California, Berkeley, oral commun., 1996). Secondary production by $D$. gilvipes in these systems, therefore, represents a potential "dead end" in the food chain. Although there are anecdotal accounts from fisherman of declines in the populations of other edible invertebrates such as large predatory stone flies (Plecoptera), and an increase in D. gilvipes in the North Umpqua River, no long-term data are available to verify these accounts.

\section{METHODS}

Standard USGS methods for sampling and analysis were used except where otherwise noted. Methods of data collection employed by the USGS, and by PacifiCorp during July 1995, are described below; the reader is referred to the original data sources for methods employed by the other researchers. Sampling sites are described for 1993-95 in table 3 and for 1995 in table 4 , along with associated station identification numbers and acronyms, river miles, and a listing of the constituents measured at each. Site acronyms in table 4, which match PacifiCorp's (1995, Volume 3) listings for previously established sites wherever possible, are used in the text of this report to abbreviate references to individual sites.

\section{U.S. Geological Survey Data Collection, 1993-95}

Hourly Monitor-In 1993, the USGS installed an hourly monitoring station at the terminus of the Wild and Scenic reach, upstream of Rock Creek (NURCM), with the cooperation of Douglas County, the BLM, and the U.S. Forest Service. The monitor records hourly values of water temperature, $\mathrm{DO}, \mathrm{pH}$, specific conductance, and turbidity. Summary data from the monitor have been published annually (U.S. Geological Survey, 1994-97). The monitor is intended to provide long-term data that may be used to document current conditions or to identify trends in water quality over time.

Reconnaissance Sampling, 1993-94-Water samples were collected at two fixed sites (NURCR, NUBWC) in 1993, at high and low flow (table 3), and analyzed for conventional constituents (suspended sediment, nutrients, major ions), trace elements, and organic compounds. Bed-sediment samples were collected from the same two sites at low flow and analyzed for trace elements, organochlorine pesticides, and total polychlorinated biphenyl (PCB) compounds. During 1994, samples were collected only at the site above Rock Creek (NURCR), during low flow. In addition to water samples, the samplings in 1994 included periphytic algae (chlorophyll $a$, ash free dry mass, species identification and enumeration, biovolume, and density). Sampling at NURCR during 1995 was done in conjunction with the basinwide synoptic survey, and also included trace elements in water in order to provide continuity with data from 1993 and 1994. For convenience, data from the 1993-94 reconnaissance samplings, which were published previously in the USGS' Annual Data reports (U.S. Geological Survey, 1994-97), are also provided in Appendix C of this report.

Synoptic Survey - A synoptic survey of the basin during low-flow conditions, based on the results of the reconnaissance samplings in 1993 and 1994, and work done by PacifiCorp in 1992-94, was carried out in July 1995. The purposes of the survey were to:

- measure temperature, $\mathrm{DO}, \mathrm{pH}$, nutrient, and periphytic-algal conditions throughout the North Umpqua River Basin;

- identify major nutrient sources and sinks and possible nutrient-limiting conditions by mass balancing streamflows and nutrient loads in the North Umpqua River from Soda Springs Reservoir to Glide; and

- assess water quality relative to State of Oregon standards and guidelines for $\mathrm{DO}, \mathrm{pH}$, water temperature, chlorophyll $a$, and algal abundance.

Sites sampled by the USGS were selected to enable the mass balancing of flow and nutrients, and to provide data on streams that were already of particular local interest because of $\mathrm{pH}$ and 
Table 3. Constituents analyzed during reconnaissance sampling at two sites on the North Umpqua River, Oregon, 1993-95 [See plate 1 for site locations. Bed sediment was analyzed for trace elements and chlorinated organic compounds. ID, identification; $x$, analyzed; -, not analyzed; *, includes habitat survey]

\begin{tabular}{ccccccc}
\hline & \multicolumn{3}{c}{ Field } & Trace & \\
measure- & Suspended \\
ments & sediment & Nutrients & $\begin{array}{c}\text { Major ions } \\
\text { (filtered) }\end{array}$ & $\begin{array}{c}\text { elements } \\
\text { (filtered) }\end{array}$ & $\begin{array}{c}\text { Organic } \\
\text { carbon }\end{array}$ Pesticides Algae sediment \\
\hline
\end{tabular}

\begin{tabular}{|c|c|c|c|c|c|c|c|c|c|c|}
\hline \multicolumn{11}{|c|}{ North Umpqua River below Steamboat Creek (Site ID 14316800, Site designation NUBWC) } \\
\hline Sept. $7,1993^{\mathrm{a}}$ & $\mathrm{x}$ & $\mathrm{x}$ & $x$ & $\mathrm{x}$ & $\mathrm{x}$ & $\mathrm{x}$ & $\mathrm{x}$ & - & - & $\mathrm{x}$ \\
\hline Dec. $8,1993^{\mathrm{b}}$ & $\mathrm{x}$ & $\mathrm{x}$ & $\mathrm{x}$ & $\mathrm{x}$ & $\mathrm{x}$ & $\mathrm{x}$ & $\mathrm{x}$ & $\mathrm{x}$ & - & - \\
\hline \multicolumn{11}{|c|}{ North Umpqua River above Rock Creek (Site ID 14317500, Site designation NURCR) } \\
\hline Sept. $8,1993^{\mathrm{a}}$ & $\mathrm{x}$ & $\mathrm{x}$ & $\mathrm{x}$ & $\mathrm{x}$ & $\mathrm{x}$ & $\mathrm{x}$ & $\mathrm{x}$ & - & - & $\mathrm{x}$ \\
\hline Dec. $9,1993^{b}$ & $\mathrm{x}$ & $\mathrm{x}$ & $\mathrm{x}$ & $\mathrm{x}$ & $\mathrm{x}$ & $\mathrm{x}$ & $\mathrm{x}$ & $\mathrm{x}$ & - & - \\
\hline July $6-7,1994^{\text {a }}$ & $\mathrm{x}$ & $\mathrm{x}$ & $\mathrm{x}$ & $\mathrm{x}$ & $\mathrm{x}$ & $\mathrm{x}$ & $\mathrm{x}$ & - & $\mathrm{x}$ & - \\
\hline Sept. $13-14,1994^{\mathrm{a}}$ & $\mathrm{x}$ & $\mathrm{x}$ & $\mathrm{x}$ & $\mathrm{x}$ & $\mathrm{x}$ & 一 & $\mathrm{x}$ & - & $\mathrm{x}^{*}$ & 一 \\
\hline July $25,1995^{\mathrm{a}}$ & $\mathrm{x}$ & $\mathrm{x}$ & $\mathrm{x}$ & $\mathrm{x}$ & - & $\mathrm{x}$ & 一 & - & $\mathrm{x}$ & 一 \\
\hline
\end{tabular}

temperature issues (Steamboat Creek and the Little River). Additional sites were sampled within the hydroproject area (table 4), by either the USGS or PacifiCorp, to help provide a link between data collected in the Wild and Scenic reach from 1993 and 1994 and data collected by PacifiCorp in the hydroproject area from 1992-94. USGS data from the 1995 synoptic survey are provided in Appendixes A, B, and E.

Sampling of periphyton was done so as to assess spatial distribution of algal abundance and species composition at sites having different habitat characteristics (that is, below dams and powerhouses, high-flow main-stem sites, and smaller tributary sites). Site community compositions also were used to assess long-term water-quality conditions (nutrient content, $\mathrm{pH}$, and water temperature). Lastly, ecological patterns (groupings) formed by sites, water-quality conditions, and algal taxa were identified using multivariate classification (Two-Way Indicator Species Analysis, or TWINSPAN) and ordination (canonical correspondence analysis, or CCA) techniques. TWINSPAN was used for the classification analysis because it identifies the species that are responsible for differences between variables (sites, in this case).

Despite their proximity to each other ( 0.3 miles), two sites intended to represent conditions below Lemolo Lake, LEM1G and LEM1T, are differentiated in this report. Although discharge at the two sites is essentially the same, the relatively high algal biomass sometimes present in the stream channel below the lake might cause uptake of nutrients in the reach between LEM1T and LEM1G. This could result in differing water-quality conditions or algal biomass at the two sites.

\section{Streamflow and Monitors}

Discharge was measured at miscellaneous sites according to standard USGS guidelines as described by Rantz and others (1982); discharge records at continuous-record gaging stations were compiled according to methods described by Buchanan and Somers (1984) and Kennedy (1983). Flow data from three gaging stations BOULDM, NUWCR, and ROCKM were obtained from
Douglas County (K. Shumway, Douglas County, written commun., 1996), which operates the gages.

Data from the monitor near Rock Creek (NURCM) were shifted on the basis of field calibration results using techniques for the computation of streamflow records (Kennedy, 1983), adapted for water-quality parameters. The monitor is located in a concrete pump house on the riverbank. Water is pumped from the river through a self-priming centrifugal pump and circulated through water baths that house the individual monitor probes measuring water temperature, $\mathrm{DO}, \mathrm{pH}$, and specific conductance. Occasionally the pumps supplying water to the monitor stopped operating during periods of high suspended-sediment movement in the North Umpqua River, resulting in missing data.

\section{Water and Sediment}

USGS samples-All chemical analyses were conducted at the USGS' National Water-Quality Laboratory (NWQL) in Arvada, Colorado, with the exception of alkalinity, which was determined in the field, and analysis of algal chlorophyll $a$ and biomass, which were determined in the USGS' Oregon District Laboratory (ODL). Chemical data were stored in the USGS' Water Storage and Retrieval data base (WATSTORE) and were automatically transferred to the Environmental Protection Agency's Storage and Retrieval data base (STORET). Analytical schedules and publications describing the methods are listed in table 5. Analytical reporting limits are listed in Appendix C.

Water samples were collected using the Equal-Width Increment (EWI) method-a depth and width integrating technique described by Edwards and Glysson (1988). Methods of sample collection and processing for organic constituents are described by Shelton (1994). Clean techniques used for the sampling and processing of inorganic samples are outlined in greater detail by Horowitz and others (1994). Equipment cleaning for organic analyses followed similar techniques with an additional methanol rinse to remove any residual organic contamination. 
Table 4. Water-quality sampling sites visited and types of data collected during the synoptic survey of the North Umpqua River Basin, Oregon, July 24-29, 1995

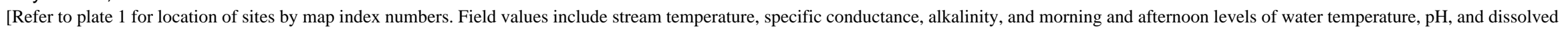
oxygen (DO), except at SEEPS, FISHP, SUSNM, and NUGLD, where $\mathrm{pH}$ and DO were measured only once during the day. Water samples were analyzed for nutrients, alkalinity, chloride,

and silica. Periphyton (P) were analyzed for chlorophyll $a$, biomass, species identification, and biovolume. Floating (F) algae (phytoplankton) were analyzed for chlorophyll $a$; No., number; RM, river mile; na, not applicable; USGS, U.S. Geological Survey; M, measured; G, gaged; E, estimated; --, not determined]

\begin{tabular}{|c|c|c|c|c|c|c|c|c|c|c|}
\hline $\begin{array}{l}\text { Map } \\
\text { index } \\
\text { no. }\end{array}$ & $\begin{array}{l}\text { Main } \\
\text { stem } \\
\text { river } \\
\text { mile }\end{array}$ & $\begin{array}{l}\text { Tributary } \\
\text { river mile }\end{array}$ & $\begin{array}{c}\text { Site } \\
\text { acronym }\end{array}$ & Site name & $\begin{array}{l}\text { USGS } \\
\text { site number }\end{array}$ & $\begin{array}{l}\text { Sampling } \\
\text { agency }\end{array}$ & $\begin{array}{l}\text { Field } \\
\text { values }\end{array}$ & $\begin{array}{l}\text { Water } \\
\text { samples }\end{array}$ & $\begin{array}{l}\text { Stream- } \\
\text { flow }\end{array}$ & Algae \\
\hline 1 & 94.8 & na & INLET & $\begin{array}{l}\text { North Umpqua River above Lemolo Lake near Inlet } \\
\text { Campground }\end{array}$ & 431839122091300 & USGS & $\mathrm{x}$ & $\mathrm{x}$ & $\mathrm{M}$ & $\mathrm{P}$ \\
\hline 2 & 93.8 & 1.0 & LAKEM & Lake Creek above Lemolo Lake & 431750122104500 & USGS & $\mathrm{x}$ & $\mathrm{x}$ & M & $\mathrm{P} / \mathrm{F}$ \\
\hline 3 & 92.9 & na & LEM1T & Top of Lemolo 1 bypass reach & 431924122111700 & PacifiCorp & $\mathrm{x}$ & $\mathrm{x}$ & -- & -- \\
\hline 4 & 92.6 & na & LEM1G & $\begin{array}{l}\text { North Umpqua River below Lemolo Lake } \\
\text { (gaged as 14313500) }\end{array}$ & 14313500 & USGS & $\mathrm{x}$ & -- & G & $\mathrm{P} / \mathrm{F}$ \\
\hline 5 & 77.3 & na & LEM2B & North Umpqua River above Lemolo No. 2 Powerhouse & na & PacifiCorp & $\mathrm{x}$ & $\mathrm{x}$ & -- & -- \\
\hline 6 & 77.1 & na & LEM2FF & North Umpqua River below Lemolo No. 2 Powerhouse & na & PacifiCorp & $\mathrm{x}$ & $\mathrm{x}$ & -- & -- \\
\hline 7 & 76.4 & na & TOKLKI & North Umpqua River above Toketee Lake & na & PacifiCorp & $\mathrm{x}$ & $\mathrm{x}$ & -- & -- \\
\hline 8 & 75.4 & 11.1 & CLRAS & Clearwater River above Stump Lake & na & PacifiCorp & $\mathrm{x}$ & $\mathrm{x}$ & -- & -- \\
\hline 9 & 75.4 & 0.0 & CLR2B & Clearwater River above Toketee Lake & na & PacifiCorp & $\mathrm{x}$ & $\mathrm{x}$ & -- & -- \\
\hline 10 & 75.4 & na & TOKET & North Umpqua River below Toketee Lake & 431552122252100 & USGS & $\mathrm{x}$ & $\mathrm{x}$ & M & $\mathrm{P} / \mathrm{F}$ \\
\hline 11 & 71.8 & 6.6 & FISHA & Fish Creek above Fish Creek Diversion & na & PacifiCorp & $\mathrm{x}$ & $\mathrm{x}$ & -- & -- \\
\hline 12 & 71.8 & 0.0 & FISHB & Fish Creek at mouth & na & PacifiCorp & $\mathrm{x}$ & $\mathrm{x}$ & -- & -- \\
\hline 13 & 69.7 & na & SODAT & North Umpqua River below Soda Springs & 431814122295100 & USGS & $\mathrm{x}$ & $\mathrm{x}$ & M & -- \\
\hline 14 & 69.7 & na & SEEPS & Seep at left bank below Soda Springs Reservoir & 431813122295100 & USGS & $\mathrm{x}$ & $\mathrm{x}$ & $\mathrm{E}$ & -- \\
\hline 15 & 69.6 & na & FISHP & Fish pond below Soda Springs Reservoir & 431821122300100 & USGS & $\mathrm{x}$ & $\mathrm{x}$ & $\mathrm{E}$ & -- \\
\hline 16 & 69.0 & na & BSODA & North Umpqua River below Soda Springs Powerhouse & 431824122300600 & USGS & $\mathrm{x}$ & $\mathrm{x}$ & -- & $\mathrm{P}$ \\
\hline 17 & 67.9 & 0.0 & BOULM & Boulder Creek near mouth & 14316495 & USGS & $\mathrm{x}$ & $\mathrm{x}$ & G & -- \\
\hline \multirow[t]{2}{*}{18} & 67.2 & na & COPEG & North Umpqua River above Copeland Creek & 14316500 & USGS & $\mathrm{x}$ & $\mathrm{x}$ & G & $\mathrm{P} / \mathrm{F}$ \\
\hline & & & & & na & PacifiCorp & $\mathrm{x}$ & -- & G & -- \\
\hline 19 & 66.6 & 0.0 & COPEM & Copeland Creek near mouth & 431730122323800 & USGS & $\mathrm{x}$ & $\mathrm{x}$ & M & -- \\
\hline 20 & 61.8 & 0.0 & CALFM & Calf Creek near mouth & 431728122370800 & USGS & $\mathrm{x}$ & $\mathrm{x}$ & M & -- \\
\hline 21 & 57.7 & 0.0 & PANTM & Panther Creek near mouth & 431815122404400 & USGS & $\mathrm{x}$ & $\mathrm{x}$ & M & -- \\
\hline 22 & 57.5 & na & NUAPC & North Umpqua River at Apple Creek & 431820122403700 & USGS & $\mathrm{x}$ & $\mathrm{x}$ & M & -- \\
\hline 23 & 53.2 & na & MOTTB & North Umpqua River at Mott Bridge & 432034122440100 & USGS & $\mathrm{x}$ & $\mathrm{x}$ & M & -- \\
\hline 24 & 53.0 & 11.9 & STEABB & Steamboat Creek above Big Bend Creek & 432523122360300 & USGS & $\mathrm{x}$ & $\mathrm{x}$ & M & $\mathrm{P}$ \\
\hline 25 & 53.0 & $0.0^{\mathrm{a}}$ & CANTM & Canton Creek near mouth & 432100122434300 & USGS & $\mathrm{x}$ & $\mathrm{x}$ & $\mathrm{G}$ & -- \\
\hline 26 & 53.0 & 0.5 & STEAM & Steamboat Creek at gage & 14316700 & USGS & $\mathrm{x}$ & $\mathrm{x}$ & G & $\mathrm{P} / \mathrm{F}$ \\
\hline 27 & 52.5 & na & NUSTM & North Umpqua River near Steamboat & 432034122442500 & USGS & $\mathrm{x}$ & $\mathrm{x}$ & -- & $\mathrm{P}$ \\
\hline
\end{tabular}


Table 4. Water-quality sampling sites visited and types of data collected during the synoptic survey of the North Umpqua River Basin, Oregon,

July 24-29, 1995 (Continued)

[Refer to plate 1 for location of sites by map index numbers. Field values include stream temperature, specific conductance, alkalinity, and morning and afternoon levels of water temperature, $\mathrm{pH}$, and dissolved oxygen (DO), except at SEEPS, FISHP, SUSNM, and NUGLD, where pH and DO were measured only once during the day. Water samples were analyzed for nutrients, alkalinity, chloride,

and silica. Periphyton (P) were analyzed for chlorophyll $a$, biomass, species identification, and biovolume. Floating (F) algae (phytoplankton) were analyzed for chlorophyll $a$; No., number; RM, river mile; na, not applicable; USGS, U.S. Geological Survey; M, measured; G, gaged; E, estimated; --, not determined]

\begin{tabular}{|c|c|c|c|c|c|c|c|c|c|c|}
\hline $\begin{array}{c}\text { Map } \\
\text { index } \\
\text { no. }\end{array}$ & $\begin{array}{l}\text { Main } \\
\text { stem } \\
\text { river } \\
\text { mile }\end{array}$ & $\begin{array}{l}\text { Tributary } \\
\text { river mile }\end{array}$ & $\begin{array}{c}\text { Site } \\
\text { acronym }\end{array}$ & Site name & $\begin{array}{c}\text { USGS } \\
\text { site number }\end{array}$ & $\begin{array}{l}\text { Sampling } \\
\text { agency }\end{array}$ & $\begin{array}{c}\text { Field } \\
\text { values }\end{array}$ & $\begin{array}{c}\text { Water } \\
\text { samples }\end{array}$ & $\begin{array}{l}\text { Stream- } \\
\text { flow }\end{array}$ & Algae \\
\hline 28 & 48.2 & na & NUBWC & North Umpqua River below Steamboat Creek & 14316800 & USGS & $\mathrm{x}$ & $\mathrm{x}$ & $\mathrm{G}$ & -- \\
\hline 29 & 48.1 & 0.0 & WRCRM & Wright Creek near mouth & 431912122482700 & USGS & $\mathrm{x}$ & -- & M & -- \\
\hline 30 & 42.1 & 0.0 & SUSNM & Susan Creek near mouth & 14317100 & USGS & $\mathrm{x}$ & -- & $\mathrm{E}$ & -- \\
\hline 31 & 36.2 & na & NURCR & North Umpqua River above Rock Creek & 14317500 & USGS & $\mathrm{x}$ & $x^{b}$ & M & $\mathrm{P} / \mathrm{F}$ \\
\hline 32 & 35.8 & na & NURCM & $\begin{array}{l}\text { Water-quality monitor on North Umpqua River above } \\
\text { Rock Creek }\end{array}$ & 14317500 & USGS & $\mathrm{x}$ & -- & -- & -- \\
\hline 33 & 35.7 & 0.0 & ROCKM & Rock Creek near mouth & 432000123000700 & USGS & $\mathrm{x}$ & $\mathrm{x}$ & M & -- \\
\hline 34 & 29.1 & 20.7 & LTBLK & Little River above Black Creek & 431221122492100 & USGS & $\mathrm{x}$ & -- & M & -- \\
\hline 35 & 29.1 & 13.0 & LTWLF & Little River at Wolf Creek Job Center & 431453122553400 & USGS & $\mathrm{x}$ & -- & M & -- \\
\hline 36 & 29.1 & 0.04 & LITGL & Little River near Glide & 431750123060000 & USGS & $\mathrm{x}$ & $\mathrm{x}$ & M & -- \\
\hline 37 & 27.8 & na & NUGLD & North Umpqua River near Glide & $431827123072200^{c}$ & USGS & $\mathrm{x}$ & $\mathrm{x}$ & -- & -- \\
\hline
\end{tabular}

${ }^{\mathrm{a} C a n t o n}$ Creek enters Steamboat Creek at river mile 0.51.

${ }^{\text {b }}$ Samples were analyzed for filtered trace elements, suspended sediment, and filtered organic carbon.

${ }^{\mathrm{c}}$ This location was gaged from 1916-18 and $1928-38$ as site number 14318500. 
Table 5. Summary of water-quality analyses conducted in the North Umpqua River Basin, Oregon, 1993-95 [USGS, U.S. Geological Survey; NWQL, USGS National Water Quality Laboratory, Arvada, Colorado; ODL, Oregon District laboratory, Portland, Oregon; CVO, USGS sediment laboratory, Vancouver, Washington; SPE, solid phase extraction, GC/MS, gas chromatography/ mass spectroscopy; HPLC, high-performance liquid chromatography]

\begin{tabular}{lccl}
\hline \multicolumn{1}{c}{ Constituent group } & $\begin{array}{c}\text { Analysis } \\
\text { location }\end{array}$ & $\begin{array}{c}\text { Laboratory } \\
\text { schedule }\end{array}$ & $\begin{array}{c}\text { Reference or analytical } \\
\text { method }\end{array}$ \\
\hline Ancillary data & NWQL, & & \\
& ODL, & -- & -- \\
Nutrients in whole and filtered water & CVO & & \\
Trace elements in whole water & NWQL & 2702,1119 & Fishman (1993) \\
Trace elements in filtered water & NWQL & -- & Fishman (1993) \\
Trace elements associated with bed sediment & NWQL & -- & Fishman (1993) \\
Organochlorine compounds associated with bed sediment & NWQL & 2400 & Arbogast (1990) \\
Pesticides in filtered water analyzed by SPE and GC/MS & NWQL & 2501 & Foreman and others (1995) \\
Pesticides in filtered water analyzed by SPE and HPLC & NWQL & 2010 & Zaugg and others (1995) \\
\hline
\end{tabular}

Filtered-water trace-element samples were analyzed by inductively coupled plasma and mass spectroscopy (ICP/MS) in a clean room designed to minimize metallic contamination. Samples for nutrients, hardness, and trace elements in whole water were analyzed according to Fishman (1993). Filtered and unfiltered nutrient samples were chilled unpreserved and shipped on ice within 24 hours to the NWQL, where they were kept chilled at $4^{\circ} \mathrm{C}$ until analysis. Nutrient analyses were performed within 7 days of delivery to the NWQL. Nutrients analyzed from the unfiltered sample were total phosphorus (TP) and total Kjeldahl nitrogen (TKN), using a Jirka modification of the Kjeldahl digestion (Patton and Truitt, 1992). The TKN analysis provides a measurement of ammonia plus organic forms of nitrogen. Nutrients analyzed in the filtered sample included a digested fraction for phosphorus (TDP) and nitrogen (TDN), and an undigested fraction for soluble reactive phosphorus (SRP), ammonia nitrogen $\left(\mathrm{NH}_{4}{ }^{+}\right)$, nitrite nitrogen $\left(\mathrm{NO}_{2}{ }^{2-}\right)$, and nitrite plus nitrate nitrogen $\left(\mathrm{NO}_{2}{ }^{2-}+\mathrm{NO}_{3}{ }^{-}\right)$. In this report, nitrite plus nitrate nitrogen is referred to simply as $\mathrm{NO}_{3}{ }^{-}$, because $\mathrm{NO}_{2}{ }^{2-}$ is typically negligible. Data for the TKN and TDN analyses were corrected by the NWQL for concentrations of the respective forms of nitrogen in the laboratory's blank samples. Because of the large number of nondetections for nitrogen in analyses from 1993, alternate methods with lowered reporting limits were used in subsequent analyses.

Ancillary data collected included alkalinity, suspended-sediment concentration, and field measurements of water temperature, $\mathrm{DO}, \mathrm{pH}$, and specific conductance. Alkalinity samples were filtered and then titrated potentiometrically in the field using 0.16 normal sulfuric acid with digital titrators. End points for the alkalinity titration were determined using an incremental method (Wood, 1976).

Water temperature, $\mathrm{DO}, \mathrm{pH}$, and specific conductance were determined using Hydrolab multiparameter probes, adapted for low-ionic strength waters. Time intervals used to measure the daily minimums and maximums in $\mathrm{DO}$ and $\mathrm{pH}$ were determined by examination of the summertime hourly record from the monitor near Rock Creek. These times were variable but tended to be between 06:00-08:00 a.m. and 4:30-6:30 p.m. During the July
95 synoptic survey, it was noted that the daily minimums and maximums tended to occur later in the morning and earlier in the afternoon, respectively, for sites located in the upper elevations of the watershed. Sampling times for diel measurements of DO and $\mathrm{pH}$ at upper elevation sites were subsequently adjusted, in an attempt to match these periods of minimums or maximums, using previously recorded data provided by PacifiCorp (1995a, volume $3)$.

Analyses of suspended-sediment concentration and computation of percent finer-than-sand (less than 62-micrometer sieve diameter) were made by the USGS Sediment Laboratory in Vancouver, Washington, as outlined by Guy (1969). Bedsediment samples were collected during low flow in 1993 with a Teflon scoop from 10 depositional areas at the 2 fixed sites (table 3 ). According to protocols for bed sampling described by Shelton and Capel (1994). Analysis of trace elements and organochlorine compounds associated with bed sediment were performed according to procedures described by Arbogast (1990) and Foreman and others (1995), respectively (table 5).

PacifiCorp-Water was collected by PacifiCorp in July 1995 as mid-channel grab samples using with a cleaned and rinsed 5-gallon plastic bucket. Aliquots were pumped into separate bottles for each constituent using a peristaltic pump. Filtered water samples were passed through an in-line 0.45 micrometer filter. New pump tubing and filters were used for each of the seven sample sites visited. Samples were stored unpreserved on ice and transported to Oregon Analytical Laboratory, in Beaverton, Oregon, within 24 hours (PacifiCorp, 1995b). Methods of sample collection for previous studies are described by PacifiCorp (1995a, volume 21).

\section{Algae}

One measure of the standing crop of the benthic community is the ash-free dry mass (AFDM) - the amount of organic matter per unit area scraped - expressed as grams per square meter $\left(\mathrm{g} / \mathrm{m}^{2}\right)$. In addition to algae, AFDM measurements also incorporate detritus and other components of the periphyton (protozoans, 
bacteria, and fungi), making it difficult to isolate the algal component. Another indirect measurement of the algal biomass, chlorophyll $a$ (expressed as milligrams per square meter, or $\mathrm{mg} / \mathrm{m}^{2}$ ), is widely used because all photosynthetic organisms utilize this plant pigment in photosynthesis. Chlorophyll $a$ can, however, underestimate algal biomass during periods of declining health, and pigment adaptation can cause much variation in the chlorophyll $a$ content of cells (Wetzel, 1983). Despite these complications, chlorophyll $a$ and AFDM values are commonly used to gauge the standing crop of algal biomass (Welch and others, 1988, 1989).

Microscopic enumeration of algal cells may also be used to assess algal biomass. Cell densities, expressed as number of cells per square centimeter (cells $/ \mathrm{cm}^{2}$ ) and determined for individual taxa, allow for analysis of community composition. Although cell densities are good indicators of individual species growth (division) rates, they can be misleading when the cell sizes from multiple species in a sample span many orders of magnitude. Measuring cell dimensions allows for the estimation of cell biovolume, expressed in cubic micrometers per square centimeter $\left(\mu \mathrm{m}^{3} / \mathrm{cm}^{2}\right)$, which corrects for variations in cell size. Algal biovolume provides a good measure of the biomass available for herbivorous consumers at higher trophic levels (Lowe and Pan, 1996).

Sample Collection and Processing-Benthic algal (periphyton) samples were collected from 10 sites (table 3) using the method described by Porter and others (1993). Representative rocks were selected in a deliberate manner from the RichestTargeted Habitat (RTH), usually riffles, in wadable areas at a sampling site.Twenty-five individual scrapings were composited (total area approximately $75 \mathrm{~cm}^{2}$ ) from five submerged rocks. At the site below Toketee Reservoir (TOKET), the thick coverage of filamentous green algae warranted the use of a Hess sampler. At this site, algal coverage appeared homogeneous; therefore, two Hess samples were collected and composited, representing a total area of $1,711.8 \mathrm{~cm}^{2}$. Algae samples were chilled for up to 8 hours until further processing.

At each site where periphyton samples were collected during the July 1995 synoptic sampling, solar availability (southerly exposure) was assessed using a Solar Pathfinder ${ }^{\mathrm{TM}}$. This method outlines the panoramic shading at a site, allowing for the estimation of solar availability (Platts and others, 1987). Data are expressed as a percent of the average total radiation that will fall on a south facing location for a given month and latitude. Canopy cover (as a percent) is obtained by subtraction of the percent of solar availability from 100 .

Periphyton samples were homogenized in an electric blender within 8 hours of collection. Aliquots of known volume for analysis of chlorophyll $a$ and AFDM were removed and filtered through 47-millimeter-diameter GF/F filters (in triplicate) and frozen prior to analysis. The rest of the sample was preserved with $5 \%$ formalin for algal identification and enumeration. Phytoplankton chlorophyll $a$ was determined from six sites using water sampled for nutrients. Known volumes were taken from a churn splitter, filtered through 47-millimeter-diameter GF/F filters (in triplicate), and frozen on dry ice prior to analysis.

Periphyton and phytoplankton chlorophyll $a$ was determined fluorometrically at the Oregon District Laboratory (ODL) following filter grinding in $90 \%$ acetone, and periphyton AFDM was analyzed gravimetrically, according to methods described by the American Public Health Association (1989). Filters for AFDM were dried at $105^{\circ} \mathrm{C}$ for 24 hours and burned at $500^{\circ} \mathrm{C}$ for 2 hours. The difference in filter weights before and after burning (corrected for filter AFDM) represents the AFDM of the sample.

\section{Periphyton identification and enumeration-}

Periphyton species composition and abundance (density and biovolume) were determined by one of two contract laboratories. Samples from three sites (NURCR, COPEG, and STEAM) were processed by the Philadelphia Academy of Natural Sciences. Three hundred algal cells were identified to lowest possible taxon and dimensions for calculating the biovolumes were made for taxa that occurred in at least 5\% abundance (S.D. Porter, U.S. Geological Survey, written commun., 1995). The 7 remaining samples were analyzed by Aquatic Analysts, Portland, Oregon; a minimum of 100 algal units were identified to the lowest possible taxon, enumerated, and measured for biovolumes. Algal units are defined as single cells for unicellular taxa, colonies for colonial taxa, and $100 \mu \mathrm{m}$ lengths for filamentous green and blue-green taxa.

Data compilation and analysis-Algal data sets from the two contractors were merged after resolving taxonomic differences. Reference diatom slides prepared and analyzed by the Philadelphia Academy of Natural Sciences were also analyzed by Aquatic Analysts for comparison. Differences between contractors were resolved by (1) renaming taxa identified by Aquatic Analysts to agree with current taxonomy, (2) folding individual species or varieties into genera (for some diatoms), or (3) combining individual genera of the blue-green algae into families on the basis of their capacity for nitrogen fixation. This process reduced the number of distinct taxa from 117 to 99. Specific information on these groupings is presented in Appendix E.

Ecological information on individual taxa from a variety of sources (Appendix E) was used to group algal taxa into autecological guilds (groups of taxa that have similar ecological tolerances, requirements, or abilities). Because periphyton integrate conditions over time, they can be used to infer ecological conditions (nutrient concentrations, $\mathrm{pH}$, and water temperatures) and can provide alternative information to instantaneous waterquality measurements (Carrick and others, 1988; Lowe and Pan, 1996) as indicators of current or changing ecological conditions. For this analysis, the percent relative abundance of each guild was determined, both for individual sites and by pooling data from all sites.

The cluster analysis program TWINSPAN (Hill, 1979), was used to determine patterns among algal communities from different sites. TWINSPAN is a dichotomous classification technique that, for this study, separated sites on the basis of algal species biovolume. Individual species, having different total biovolumes among samples from different sites, are grouped into predetermined discreet intervals (cut levels) referred to as pseudospecies (Hill, 1979). Nine pseudospecies cut levels were used (0, 0.1, $0.25,0.5,1,5,25,50$, and 100 million $\mu \mathrm{m}^{3} / \mathrm{cm}^{2}$ ), based on the overall distribution of taxa biovolumes from all sites. TWINSPAN also identifies the indicator taxa responsible for the divi- 
sions at each classification level and displays the output as a tree diagram.

Canonical correspondence analysis (CCA) (ter Braak, 1986) was also used to identify relationships among sites, species, and environmental (chemical and physical) data. CCA is a direct gradient technique that combines ordination and multiple regression to simultaneously evaluate patterns among sites on the basis of algal taxa abundance (for example, taxa biovolumes) and environmental data. The results of this analysis are displayed in a triplot diagram. For a more detailed discussion on the use of CCA, readers are referred to the ordination chapter by ter Braak in Jongman and others (1995).

\section{Quality Assurance}

Quality assurance was incorporated into the sampling programs in a variety of ways, including (1) daily pre- and postcalibration of Hydrolabs, (2) weekly to biweekly calibration of the hourly monitor near Rock Creek (NURCR), (3) collection of blank samples to test equipment and techniques for contamination, (4) collection and submission of replicate, split, spiked, and/ or reference water-quality samples to test for precision and accuracy, and (5) sample collection and analysis at one site (INLET) concurrent with collection by PacifiCorp during July 1995. Because nutrient data collected by USGS and PacifiCorp are combined and compared in this report, the quality assurance data for nutrients are given extra emphasis below.

\section{Water and Sediment}

On a daily basis, Hydrolabs were calibrated before and after use according to the manufacturer's recommendations. Slight linear shifts were applied when differences between calibration standards and probe readings exceeded $0.2^{\circ} \mathrm{C}, 0.2 \mathrm{mg} / \mathrm{L}$ of DO, $0.2 \mathrm{pH}$ units, or $5 \%$ of the specific conductance standard. Similarly, probes from the hourly monitor at NURCM were calibrated weekly or biweekly. Data from the monitor were adjusted on the basis of field calibration results according to Kennedy (1983). Annual cross-sectional measurements of water temperature, $\mathrm{DO}, \mathrm{pH}$, and specific conductance from the water sampling site 0.1 miles upstream (NURCR) were used to check the monitor readings for a total of 7 individual days between 1993 and 1995.

Field and equipment blank samples (Appendix B) from initial reconnaissance samplings in 1993 indicated the potential for contamination of filtered trace-element samples by low-level concentrations of zinc $(3 \mu \mathrm{g} / \mathrm{L})$ and aluminum $(2$ and $5 \mu \mathrm{g} / \mathrm{L})$. In 1993, the ultrapure nitric acid originally used for preservation of trace-element samples was discovered to have potentially been contaminated with low concentrations of several trace elements, including zinc and aluminum, derived from the glass ampules in which it was shipped. These ampules were replaced with Teflon ampules in 1994. Contamination with aluminum and zinc also may have come from the aluminum boat used for the sampling at NURCR, despite the clean procedures employed at the time. Field-blank samples for trace elements in 1994 and 1995 from the same sites indicated no further contamination. Data from
1993 were corrected for the potential zinc and aluminum contamination by subtracting the blank water concentrations from the native water concentrations. This correction affected four zinc concentrations and one aluminum concentration from September and December 1993 (Appendix B). There were no detections of pesticides in either of two blank samples from 1993.

One field blank sample from July 1995 (out of three taken) had $1 \mu \mathrm{g} / \mathrm{L}$ of TP detected in it. This concentration is small, however, compared with the concentrations of TP observed at this and most other sites in the basin; therefore, TP concentrations were not adjusted to reflect the contamination. Results from the other two field blanks revealed no other detections of nutrients. A blank sample collected and processed by PacifiCorp in 1995 showed a detection for TP of $10 \mu \mathrm{g} / \mathrm{L}$, a value which was at the instrument detection limit employed by PacifiCorp's contract laboratory. Although a blank water concentration of $10 \mu \mathrm{g} / \mathrm{L}$ is relatively high, it was less than one-half of all TP concentrations reported by PacifiCorp during the July 1995 synoptic survey.

A standard reference sample was submitted to the NWQL for analysis of nutrients during the July 1995 synoptic survey (table 6). The sample, prepared in the ODL as part of an established quality control program with the United Sewerage Agency (Doyle and Caldwell, 1996) contained known concentrations of nutrients in water that was previously certified to be free of inorganic constituents at the microgram per liter level. Concentrations of nutrients were deliberately chosen to reflect the concentrations previously observed in the North Umpqua River Basin. The same reference-sample water was also provided to PacifiCorp for simultaneous analysis and comparison with USGS results. The results of the USGS and PacifiCorp analyses were reasonably close to the expected reference concentrations for all nutrient species except TP. USGS results for $\mathrm{NO}_{3}{ }^{-}, \mathrm{NH}_{4}{ }^{+}$, and TP were biased low; however, relative differences are magnified at these low concentrations. PacifiCorp's data appeared similarly low, with the exception of the high TP value. Bias for PacifiCorp's analysis of $\mathrm{NO}_{3}{ }^{-}$could not be assessed because the value was below the instrument detection limit.

Concurrent native water samples collected at one site (LEM1T) by the USGS and PacifiCorp indicated relatively close agreement for nutrient, chloride, and silica concentrations, also with the exception of TP (table 6). Although SRP values at LEM1T reported by the USGS and PacifiCorp were similar, TP was substantially higher in PacifiCorp's analysis, as it was for the standard reference sample. An examination of native water data collected by PacifiCorp from other sites during July 1995 (Appendix D) indicates that several other sites had reported TP concentrations that are relatively high for the basin. Because these sites are located in the headwater areas of the upper North Umpqua River Basin, within the Western Cascades geological province, whose underlying rocks are known to be rich in phosphorus, these values possibly are representative. However, on the basis of the analytical results of the standard reference sample and the concurrent sample, it also is possible that PacifiCorp's TP data are biased high for some samples. A replicate sample submitted by PacifiCorp indicates good agreement for all constituents except TKN (table 6). There is no known reason for this discrepancy in TKN results. Although the quality assurance data 
Table 6. Comparison of water-chemistry of samples collected and analyzed by the U.S. Geological Survey and by PacifiCorp in the North Umpqua River Basin, Oregon, during July 1995

[Refer to table 4 for list of site acronyms with site identification numbers and location. <, less than; USGS, U.S. Geological Survey; PC, PacifiCorp; $\mu \mathrm{g} / \mathrm{L}$, micrograms per liter; mg/L, milligrams per liter; $\mathrm{N}$, nitrogen; $\mathrm{P}$, phosphorus; $\mathrm{CaCO}_{3}$, calcium carbonate; --, not analyzed]

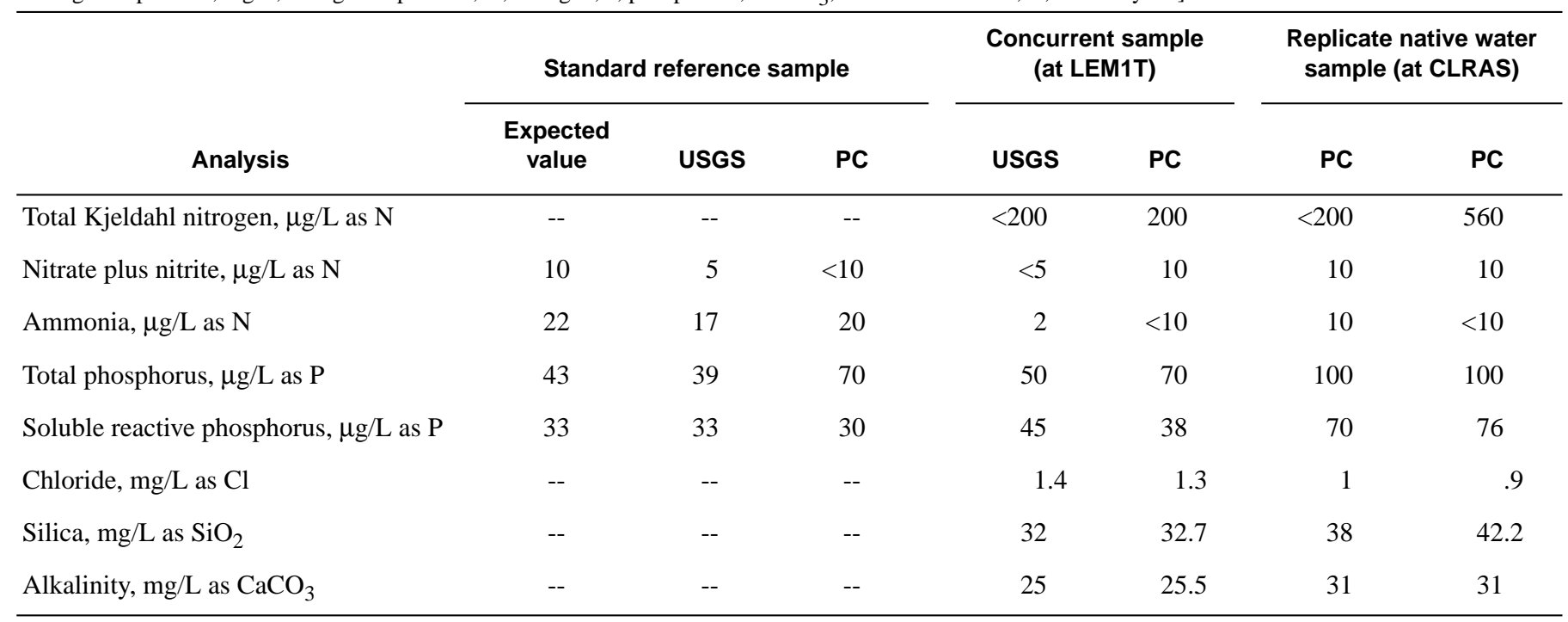

indicate possible biases in the environmental data, it was not possible to adjust either the USGS or PacifiCorp's data to account for these differences. Both data sets are used together in this report, and possible discrepancies due to data differences are noted where relevant.

During the July 1995 synoptic survey, one site (COPEG) was sampled for nutrients twice (3 days apart). This site was considered critical to the integrity of mass balances developed for nutrients during the synoptic survey because it is close to Soda Springs powerhouse, which is the source of water to the Wild and Scenic reach; it is also the most upstream site in the main stem where the entire cross section can be accessed by cableway. Hence, these results were a potentially important indicator of temporal variability of nutrient input to the main stem. The main differences noted were a decrease in phosphorus concentrations and an increase in the ammonia concentration between the first and the second sampling (Appendix A). These data and their implications are discussed in the nutrient section of the report. Replicate samples from 1993 for nutrients and trace elements in water and for trace elements and chlorinated organic compounds in bed sediment indicate good precision for all constituents (Appendixes B and C) and do not warrant further discussion.

\section{Algae}

The often patchy growth of periphyton (Cazaubon and others, 1995) increases variability in algal sampling. All chlorophyll $a$ and AFDM samples were analyzed in triplicate to characterize analytical variability. The triplicate samples analyzed for AFDM had acceptable reproducibility (median relative standard deviation 20.8\%) with a few exceptions. Samples containing filamentous green algae had higher standard deviations for chlorophyll $a$ and AFDM.

To investigate variability due to sampling technique, two replicate periphyton samples for taxon identification and enumeration were collected by different methods and by different individuals from a riffle at NURCR. Rocks were selected using a deliberate, representative technique in replicate 1 (identical to the method used at the other nine sites) and by selecting rocks randomly for replicate 2 . This comparison allows an assessment of the inherent variability when comparing algae data among sites. It represents a worst-case comparison because of the differences in methods and individuals for selecting rocks. Finally, slide preparations of diatoms from three sites (COPEG, STEAM, and NURCR) were each analyzed by the two contract laboratories for comparison.

The two replicate algae samples collected by different individuals from NURCR show that all four measures of algal abundance (table 7) were consistently higher in replicate 1 than in replicate 2. Rocks sampled for replicate 1 at NURCR and at all the other sites were selected to represent a range of conditions (depth, water velocity, algal abundance). Replicate 2 was collected in the same riffle as replicate 1 , but rocks were randomly selected. Despite the intrasite variability, however, the differences in algal biovolume in the replicate samples were small compared to differences among sites (Appendix E); for instance, algal biovolumes at the hydroproject sites were approximately 5-15 times higher than those in replicate 1 at NURCR.

The differences in algal abundance between the two replicate samples were primarily due to differences in algal community composition. Thirty taxa were identified in replicate 1 compared with 43 taxa in replicate 2 (Appendix E). Comparisons between environmental tolerances of the algal communities (autecological guilds) from the replicate samples were, however, similar with a few exceptions. The percent relative biovolumes of nitrogen fixers and alkaliphilic taxa in replicate 2 were each about $60 \%$ higher than in replicate 1 (table 7). This difference was attributed to a higher biovolume of Epithemia sp. (a large nitrogen fixing and alkaliphilic diatom) in replicate 2 (Appendix E). The relative densities of guilds from the two samples were also similar.

For both multivariate analyses (TWINSPAN and CCA), replicate 1 from NURCR was used because this sample was 
Table 7. Quality-assurance data for algal abundance (chlorophyll a, ash-free dry mass [AFDM], total biovolume, and total cell density), and percent relative biovolumes and densities of autecological guilds from two replicate samples from the North Umpqua River above Rock Creek, Oregon, July 1995

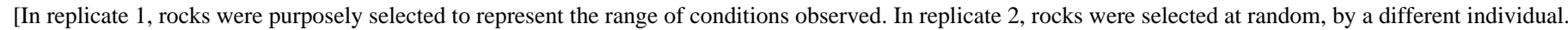

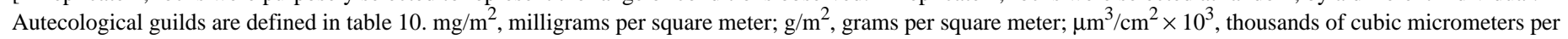
square centimeter; $\%$, percent; <, less than]

\begin{tabular}{lcc}
\hline \multirow{2}{*}{ Measure } & \multicolumn{2}{c}{ Algal abundance } \\
\cline { 2 - 3 } & Replicate 1 & Replicate 2 \\
\hline Chlorophyll $a\left(\mathrm{mg} / \mathrm{m}^{2}\right)$ & 59 & 30 \\
AFDM $\left(\mathrm{g} / \mathrm{m}^{2}\right)$ & 8.4 & 3.4 \\
Total biovolume $\left(\mu \mathrm{m}^{3} / \mathrm{cm}^{2} \times 10^{3}\right)$ & $1.4 \times 10^{5}$ & $1.1 \times 10^{5}$ \\
Total density (number of cells) & $3.3 \times 10^{3}$ & $2.2 \times 10^{3}$ \\
\hline
\end{tabular}

\begin{tabular}{|c|c|c|c|c|}
\hline \multirow[b]{2}{*}{ Algal guild ${ }^{a}$} & \multicolumn{2}{|c|}{ Relative biovolume (\%) } & \multicolumn{2}{|c|}{ Relative density (\%) } \\
\hline & Replicate 1 & Replicate 2 & Replicate 1 & Replicate 2 \\
\hline Nitrogen fixers & 36 & 58 & 92 & 91 \\
\hline Nitrogen heterotrophs & 4 & 4 & 2 & 2 \\
\hline Eutrophic taxa & 25 & 17 & 4 & 3 \\
\hline Oligotrophic taxa & 3 & 1 & 1 & $<1$ \\
\hline Alkaliphilic taxa & 38 & 63 & 3 & 3 \\
\hline Cold-water taxa & 2 & $<1$ & $<1$ & 0 \\
\hline
\end{tabular}

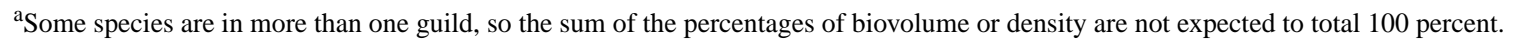

collected in the same manner as those at the other nine sites. To reduce the number of taxa input to the multivariate analysis, a minimum criterion of $1 \%$ of the total site biovolume was established, which reduced the number of taxa from 99 to 60 .

The slide preparations of diatoms, from COPEG, STEAM, and NURCR, as analyzed by the two contract laboratories, did have some differences. Discrepancies concerning the taxon names reported by Aquatic Analysts were resolved by renaming these taxa to agree with the Philadelphia Academy of Natural Sciences results. For example, the genus Fragilaria has been split into six genera (Williams and Round, 1987), two of which were found in this study. Taxon presence and percent densities between the two laboratories also had some differences that might be attributable to the numbers of cells identified by each (see p. 18). In general, the differences could be resolved, and it was determined that the two data sets could be merged, as described previously.

To assess the spatial variability of algal biomass, three periphyton samples were collected from BSODA: (1) one sample representative of rocks with moderate to light growth for that site, (2) one sample using the standard, representative rock selecting technique as at all other sites, and (3) one sample representative of abundant algal growth. Chlorophyll $a$ from these samples were 187,209 , and $440 \mathrm{mg} / \mathrm{m}^{2}$, respectively and AFDM was 51,68 , and $395 \mathrm{~g} / \mathrm{m}^{2}$, respectively. These data confirm that the standard sample had biomass values intermediate between the light and heavy samples, and illustrate the lack of uniformity in algal growth along the riverbed at this site. Periphyton abundance determined from the standard technique at BSODA was more similar to rocks having only moderate growth. The high concentrations of chlorophyll $a$ and AFDM from rocks with abundant growth, in particular, reflect the thick filaments of green algae, which were about 6 inches in length. The AFDM from this sample was disproportionately high $\left(395 \mathrm{~g} / \mathrm{m}^{2}\right)$, possibly reflecting the accumulation of dead organic matter within the algal mat. The triplicate samples analyzed for periphyton and phytoplankton chlorophyll $a$ had good reproducibility; median RSDs were $7.8 \%$ and $4.0 \%$, respectively.

\section{RESULTS}

Results of the individual types of water-quality measurements and analyses are described in the following sections, with special emphasis on the synoptic survey in July 1995. Water-quality data from the survey are compiled in Appendix A, and data from previous years are compiled in Appendix C. Integration of these results and their potential interrelations are explored further in the "Relations of Water Quality and Algae to Resource Management" section of this report.

\section{Hydrologic Conditions}

Flow conditions in the North Umpqua River Basin are primarily controlled by the interaction of four factors: (1) seasonal cycles of snowfall and snowmelt in the upper elevations, (2) ground-water input in the upper elevations, (3) seasonal cycles of winter rain and warm, dry summers in lower elevations, and (4) the hydroproject and its associated diversions and regulation of flows. As a result of the combination of these factors, the main stem of the North Umpqua in the Wild and Scenic reach has a 
relatively high stable flow during summer, despite low flows in most tributaries. The Wild and Scenic reach also can have extremely high flows during winter that result from heavy rains or periods of rain on snow.

\section{Temporal and Spatial Variability}

The effect of elevation and snowfall on the timing of runoff at selected gaging stations in the North Umpqua River Basin is illustrated qualitatively in table 8; a site in the forested region of the South Umpqua River, which gets very little snowmelt (Rinella, 1986) is included for comparison. The table is arranged by elevation from highest to lowest sites, with the exception of the station at the South Umpqua River near Tiller. Several discontinued sites, such as the North Umpqua River above Rock Creek (currently the NURCR site), and North Umpqua River near Glide (NUGLD), that provided streamflow information prior to the construction of the hydroproject, are included to indicate historical runoff patterns. Data from the Little River at Peel are included because they represent the best record of long-term flow in the Little River system. It is recognized that the periods of record for these discontinued sites do not include recent years and climate conditions; therefore, records from these sites are not directly comparable to records from current gaging stations.

The amount of average annual runoff that occurs during the winter at sites listed in table 8 ranges from about $40 \%$ at Clearwater River (snowmelt and ground-water controlled) to over $80 \%$ at the downstream sites (rainfall controlled). The streams with the highest amount of winter runoff are Steamboat Creek and Little River - the two streams with entirely unregulated flow and the lowest elevation watersheds. These streams also are in the most heavily logged subbasins in the study area. The percentage of annual winter runoff for the years 1924-45 at NURCR, where the river carries the combined flow of the upper North Umpqua River and Steamboat Creek, was intermediate to the percentage recorded at upstream sites and at Steamboat Creek. These differences are large enough that their magnitude is probably independent of the differences in periods of record.

Also evident from table 8 is the effect of diversions within the hydroproject on the timing and magnitude of downstream flows. Annual average flows at the Clearwater River gaging station (within the Clearwater No. 1 bypass reach) were reduced by almost a factor of 10 after diversion, and the percentage of winter runoff also was decreased.

Summer flows in the bypass reaches of the principal rivers of the hydroproject (illustrated in fig. 1 by the flow at LEM1G) are reduced by diversion to the minimum permitted amounts (table 1) plus ground-water inflows. Reductions of flow in the bypass reaches during summer has occurred downstream from each of the other major dams and diversions within the hydroproject area in a manner similar to that observed at LEM1G. Analysis of flood frequency by PacifiCorp (1995a, volume 3) for the bypass reach downstream of Lemolo Lake and in the Clearwater River downstream of Stump Lake indicates that post hydroproject peak flows with recurrence intervals of 1.05 to 2 years had been reduced to $47 \%$ to $85 \%$ of prehydroproject peak flows of the same recurrence intervals. Peak flows at LEM1G with intermediate recurrence intervals (5-10 years) do not appear to have been greatly affected by regulation, presumably because of the low flood-storage capacities of the reservoirs. Analysis of long-term peak flows at LEM1T (20-100 year recurrence intervals) indicates significant increases after reservoir construction; however, this apparent anomaly could have been caused by the short periods of record involved or by irregularities in the statistical analysis of peak flows (PacifiCorp, 1995a, volume 3). The combination of reduced summer flow and reduced peak flows could have an effect on the composition of the biological communities in the bypass reaches (Wooten and others, 1996), a factor that is discussed in more detail later in this report.

The effects of snowmelt and the relative magnitude of flows entering the Wild and Scenic reach during the period of data collection encompassed in this report are also illustrated in figure 1. Tributary inputs notwithstanding, discharge throughout the Wild and Scenic reach during summer low flow (June to October) is well described by the flow at the North Umpqua River above Copeland Creek (COPEG) streamflow-gaging station and is dominated by releases from Soda Springs Reservoir. Mean daily flow at COPEG during June to October is about 1,100 $\mathrm{ft}^{3} / \mathrm{s}$ (Moffatt and others, 1990), although there can be daily fluctuations in flow of more than $50 \mathrm{ft}^{3} / \mathrm{s}$ resulting from changes in releases from the hydroproject in order to meet power demands. Contributions of flow from Steamboat Creek (approximately $134 \mathrm{ft}^{3} / \mathrm{s}$ ) and other tributaries in June through October are relatively small. In contrast, peak discharge during the winter can be substantially higher in Steamboat Creek (STEAM) than at COPEG, primarily as a result of rainfall at the lower elevations (upstream of STEAM) and snowfall at the higher elevations (upstream of COPEG). Short residence times at impoundments within the hydroproject area prevent the impoundments from providing large amounts of flood-storage capability, except at Lemolo Lake, which is drawn down during the winter and thus has greater capacity to absorb floodwaters.

In order to meet the objectives of the July 1995 synoptic survey, steady low flows were required, particularly downstream of Soda Springs. Steady flow was necessary to facilitate mass balancing of flows and constituents, whereas low flows were necessary to achieve worst case conditions in order to properly assess the effects of benthic metabolism on water-quality characteristics such as DO and pH. To that end, PacifiCorp agreed to hold flows from Soda Springs Reservoir as steady as possible for the duration of the study. Flows during the survey (July 24-29, 1995) and the entire month of July are illustrated in the inset in figure 1. Although it is clear that the desired steady flows were achieved during the week of the study, it is also evident from the record at COPEG that main-stem flows in the summer can be variable. Thus, the flow conditions experienced during this study were not typical of summer flow conditions, and therefore the effect of temporal flow changes on water quality were not specifically addressed.

Flow-duration analysis at the three sites shown in figure 1 indicate that the flows experienced during the synoptic survey were reasonably low (fig. 3) except at LEM1G. The flow record at NURCR, which is the site at which the greatest amount of data have been collected, was simulated by summing flow records at STEAM and COPEG to provide information about flow conditions during other sample collection periods. Most of the summer 
Table 8. Annual discharge statistics for selected sites within the North Umpqua River Basin, Oregon, including the South Umpqua River at Tiller, Oregon, for comparison

[Data Sources: A, U.S. Geological Survey's Water Information Storage and Retrieval (WATSTORE) system; B, Moffatt and others (1990); C, U.S. Geological Survey (1994). pre, pre-power diversion; post, post-power diversion; *, The period of record for North Umpqua River at Glide includes a gap in record from 1919 to 1928 . ft, feet; $\mathrm{ft}^{3} / \mathrm{s}$, cubic feet per second; $\mathrm{mi}^{2}$, square miles]

\begin{tabular}{|c|c|c|c|c|c|c|c|c|}
\hline \multirow{2}{*}{$\begin{array}{c}\text { Station } \\
\text { (USGS station } \\
\text { number, site acronym) }\end{array}$} & \multirow[b]{2}{*}{$\begin{array}{l}\text { Data } \\
\text { source }\end{array}$} & \multirow{2}{*}{$\begin{array}{l}\text { Drainage } \\
\text { area } \\
\left(\mathrm{mi}^{2}\right)\end{array}$} & \multirow[b]{2}{*}{$\begin{array}{l}\text { Elevation } \\
\quad \text { (ft) }\end{array}$} & \multirow[b]{2}{*}{$\begin{array}{l}\text { Period of } \\
\text { record }\end{array}$} & \multicolumn{3}{|c|}{ Average annual streamflow, in $\mathrm{ft}^{3} / \mathrm{s}$} & \multirow{2}{*}{$\begin{array}{c}\text { Percent of } \\
\text { average annual } \\
\text { streamflow between } \\
\text { November } 1 \text { and April } 30\end{array}$} \\
\hline & & & & & $\begin{array}{l}\text { Minimum } \\
\text { (year) }\end{array}$ & Mean & $\begin{array}{l}\text { Maximum } \\
\quad \text { (year) }\end{array}$ & \\
\hline \multirow[t]{2}{*}{$\begin{array}{l}\text { Clearwater River above } \\
\text { Trap Creek (14314500) }\end{array}$} & A & 41.6 & $3,862.8$ & $\begin{array}{l}1928-52 \\
\text { (pre) }\end{array}$ & 114 & 155 & 220 & 49.1 \\
\hline & & & & $\begin{array}{l}1954-95 \\
\text { (post) }\end{array}$ & 5.9 & 17.6 & 45.3 & 37.6 \\
\hline $\begin{array}{l}\text { North Umpqua River } \\
\text { above Copeland Creek } \\
\text { (14316500), COPEG) }\end{array}$ & $\mathrm{C}$ & 475 & 1,580 & 1949-94 & 897 & 1,460 & 2,080 & 58.0 \\
\hline $\begin{array}{l}\text { Steamboat Creek near } \\
\text { Glide }(14316700, \\
\text { STEAM) }\end{array}$ & $\mathrm{C}$ & 227 & $1,128.5$ & 1957-94 & 239 & 714 & 1,253 & 85.6 \\
\hline $\begin{array}{l}\text { North Umpqua River } \\
\text { above Rock Creek } \\
(14317500, \text { NURCR) }\end{array}$ & B & 886 & 770 & $1924-45$ & 1,390 & 2,260 & 3,960 & 69.6 \\
\hline $\begin{array}{l}\text { Little River at Peel } \\
(14318000, \text { LTGLD) }\end{array}$ & B & 177 & 832 & $1954-87$ & 158 & 472 & 806 & 85.0 \\
\hline $\begin{array}{l}\text { North Umpqua River } \\
\text { near Glide (14318500, } \\
\text { NUGLD) }\end{array}$ & B & 1,210 & 645 & $1916-38 *$ & 1,880 & 3,110 & 4,280 & 82.1 \\
\hline $\begin{array}{l}\text { South Umpqua River } \\
\text { near Tiller }(14308000)\end{array}$ & $\mathrm{C}$ & 449 & 992 & 1940-94 & 268 & 1,009 & 1,762 & 83.2 \\
\hline
\end{tabular}

samplings at NURCR, including those in July 1995, have occurred at flows that are exceeded approximately $70-99 \%$ of the time. Samples have not been collected during the highest flows typical of these rivers; however, flows during the December 8-9, 1993, reconnaissance sampling which reflect the effects of a winter storm, are exceeded only $20 \%$ of the time. Figure 3 also illustrates the effect of the dam at Lemolo Lake on flow at LEM1G, where flows are usually less that $40 \mathrm{ft}^{3} / \mathrm{s}$ except during winter storms or canal maintenance periods.

\section{Flow Balance}

Because the transport of nutrients and other constituents is determined by water movement in rivers, investigation of nutrient sources depends on an understanding of the underlying flow dynamics. The flow balance is determined by adding measured sources (tributaries) to a measured starting value (main-stem site) for a given reach, and comparing the sum to a measurement at the downstream end of the reach. The resulting difference represents the error associated with the measured inputs and indicates potential unmeasured sources, such as ground-water or other tributary inputs (if the observed is higher than the estimated), or potential sinks, such as withdrawals for irrigation or intergravel flow (if the estimated is higher than the observed). Given that typical errors associated with flow measurements range from $2 \%$ for an excellent measurement to over $8 \%$ for a poor measurement
(Rantz and others, 1982), it is reasonable to expect combined errors of approximately $10 \%$ (or less) between the expected and observed flow for a reach with upstream and downstream measurements and at least one measured inflow.

Flow data for the Wild and Scenic reach of the North Umpqua River were balanced for the period of the synoptic survey, using Soda Springs Reservoir as the upstream boundary and Glide as the downstream boundary (fig. 4). Flow at sites upstream of the Soda Springs bypass reach (SODAT) is indicated for reference. With the complex routing of water through diversion canals, penstocks, powerhouses, and various tributaries, no attempt was made to balance flows within the hydroproject area. In the flow balance, a measured main-stem discharge is added to measured tributary input to estimate downstream main-stem discharge, and that total is compared with measured discharge at the downstream end of the indicated reach. The error is the difference between the measured and the estimated discharge. For example, the estimated discharge at NUAPC $\left(972 \mathrm{ft}^{3} / \mathrm{s}\right)$ was calculated as the discharge at COPEG plus the measured tributary inputs from COPEM, CALFM, and PANTM. Measured discharge at NUAPC $\left(928 \mathrm{ft}^{3} / \mathrm{s}\right)$ was approximately $4.5 \%$ less, indicating a small measurement error or a small loss of water within that reach.

The Wild and Scenic reach of the North Umpqua River achieves full flow below the Soda Springs powerhouse (BSODA), and hence estimated flow is shown in figure 4 as 

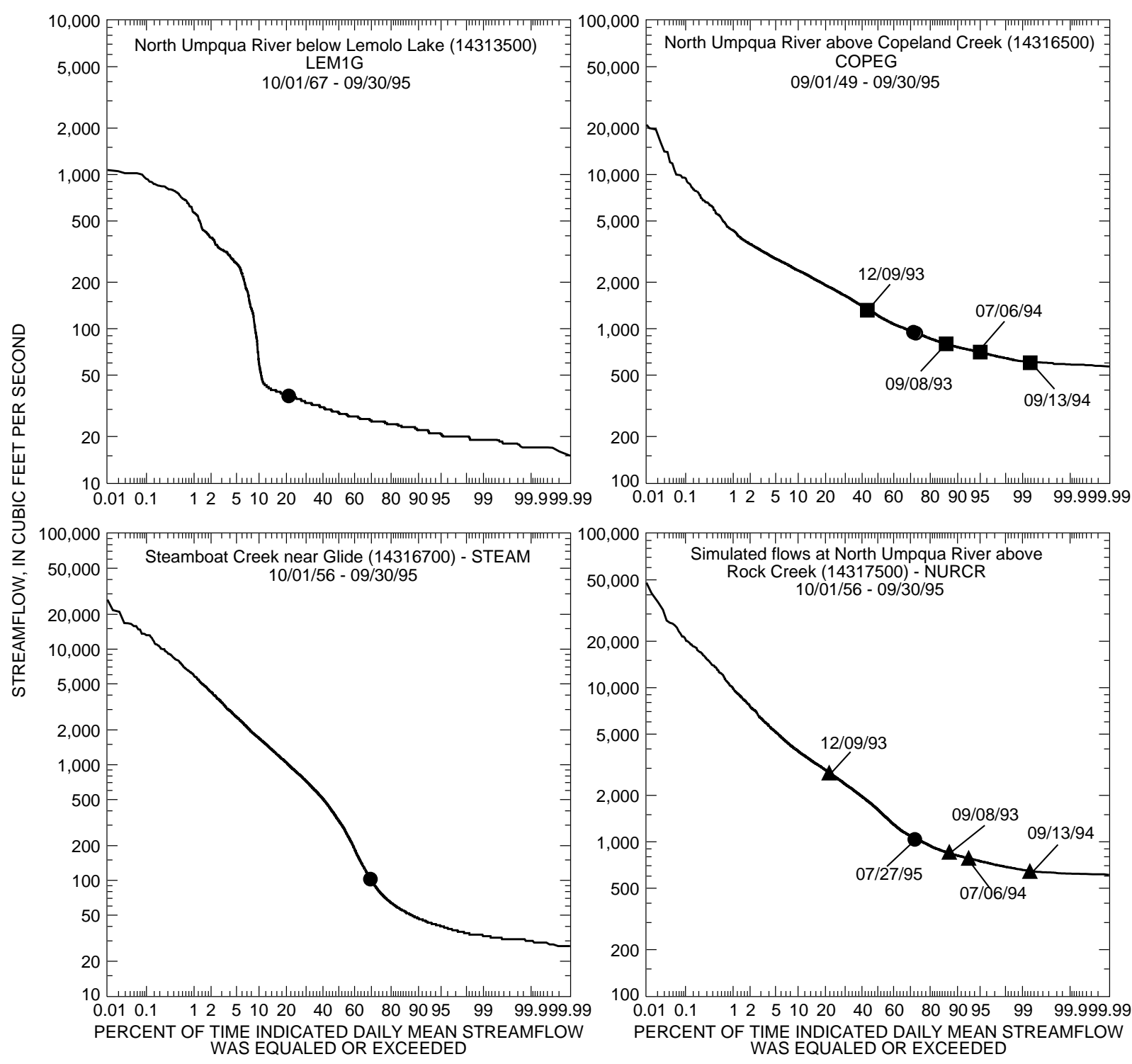

EXPLANATION

Exceedance curve for daily mean streamflow

Instantaneous streamflow during synoptic sampling from July 24-27, 1995

- Daily mean streamflow measured at North Umpqua River above Copeland Creek on date of water-quality sampling at North Umpqua River above Rock Creek

A Simulated daily mean streamflow at North Umpqua River above Rock Creek on date of water-quality sampling

Figure 3. Flow duration curves for three sites and simulated streamflow at one site in the North Umpqua River Basin, Oregon, indicating streamflows during sampling dates.

starting abruptly at BSODA, between RM 69 and 70. Tributary inflows are minor with the exception of Steamboat Creek (STEAM), Rock Creek (ROCKM), and Little River (LTGLD). Differences in the flow balance are in the range of 5 or $6 \%$ in reaches between BSODA and NURCR, and there was a $10 \%$ difference between the measured and the estimated flow at NURCR. Flow could not be measured at NUGLD due to equipment problems, so there is no way to ascertain the accuracy of the estimated flow at that site.

Because computed differences between measured and estimated flows were no greater than $10 \%$, the flow balance is con- sidered to have provided a fair accounting of input sources of water. This conclusion is further justified by the fact that the differences were alternately positive and negative in sign, implying random measurement variability rather than systematic underestimation or overestimation of flow. The $10 \%$ increase between estimated and measured flow at NURCR could indicate the presence of an important ground-water input in the reach downstream of Wright Creek (NUBWC), or it could the result of cumulative measurement variability at NUBWC and NURCR,.

The general flow agreement was verified by using a balance calculated for the load (mass transported per time) of chloride, a 


\section{Flow Balance}

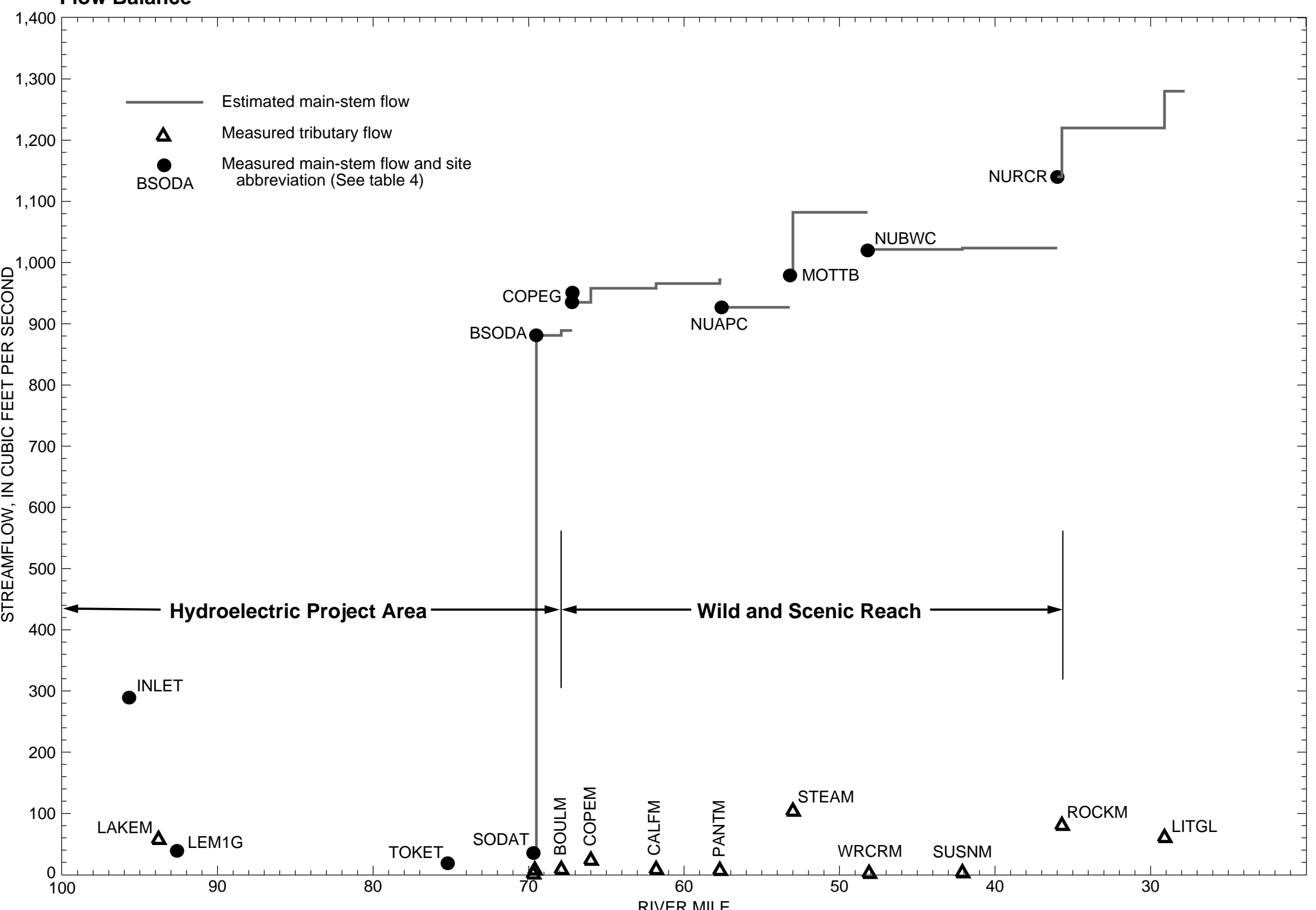

Figure 4. Flow balance in the North Umpqua River Basin, Oregon, July 24-29, 1995. (Discharge at BSODA was determined from PacifiCorp on the basis of power-generation records. Discharge at COPEG is indicated twice to correspond with two separate water-quality samplings at that site.) 
conservative constituent. Differences between measured and estimated loads were very similar to those for discharge, with 5 to $6 \%$ differences in reaches between BSODA and NUBWC. The difference between estimated and measured load between NUBWC and NURCR was $10.5 \%$, the same as that calculated for discharge in the same reach. In order for this difference to have been the result of ground-water inflow, the chloride concentration in the ground water would need to be within $1 \%$ of the chloride concentration in surface water in that reach $(1.6 \mathrm{mg} / \mathrm{L})$. Data for chloride in ground water along the Wild and Scenic reach are not available; however, in the nearby Sutherlin area, chloride concentrations in ground water range from 2.3 to over $1,000 \mathrm{mg} / \mathrm{L}$ (Robison, 1974). It is therefore unlikely that ground-water inflows are responsible for the differences observed in flow and chloride balances in the reach below NUBWC, and these differences are likely attributable to variability in streamflow measurements.

\section{Major Ions, Trace Elements, and Organic Compounds}

A suite of major ions and trace elements in water was analyzed in high- and low-flow reconnaissance samples from 1993 and 1994, and trace elements were again analyzed at the fixed site above Rock Creek (NURCR) in 1995. In addition, trace elements in bed sediment from the two sites originally sampled, NURCR and the site near Wright Creek (NUBWC), were analyzed in 1993 (Appendix C).

Major ions-Concentrations of both anions and cations are low in the North Umpqua River. Total dissolved solids (TDS) concentrations ranged from 39 to $60 \mathrm{mg} / \mathrm{L}$ in the four samples from NURCR during 1993 and 1994, and concentrations were equivalent at NUBWC and NURCR. Summer alkalinities at NURCR and NUBWC were about $30 \mathrm{mg} / \mathrm{L}$ as $\mathrm{CaCO}_{3}$ during 1993 and 1994. During July 1995 alkalinities ranged from a low of 17 at the mouth of Lake Creek (LAKEM) to a high of 51 at the mouth of the Little River (LTGLD), with a median of $27 \mathrm{mg} / \mathrm{L}$ as $\mathrm{CaCO}_{3}$.

Calcium and sodium were the predominant cations, accounting for about $40 \%$ and $30 \%$ of the total cationic charge, respectively; magnesium comprised about $20 \%$. Over $80 \%$ of anions were present as bicarbonate (calculated from alkalinity values); chloride and sulfate accounted for a little over $10 \%$ of the anionic concentrations. Concentrations of all major ions, except sulfate, were slightly reduced during the high-flow period sampled in December 1993. Samples from NURCR and NUBWC had similar concentrations of major ions, and the two sites appear to be equivalent with respect to inorganic constituents. No data are available for major ions upstream of Steamboat Creek or within the hydroproject area with which to make source comparisons. Silica concentrations during low flows were identical at NUBWC and NURCR (25 mg/L) from 1993-95. Silica decreased in a downstream direction throughout the basin during 1995, most likely reflecting a combination of dilution from tributary inputs and uptake by diatoms for incorporation into their frustules.

Concentrations of dissolved and suspended organic carbon were also low at NUBWC and NURCR during 1993 and 1994. During the summer samplings the median dissolved organic car- bon (DOC) concentration was $0.8 \mathrm{mg} / \mathrm{L}$, with no appreciable differences between sites, and the median suspended organic carbon (SOC) concentration was approximately $0.4 \mathrm{mg} / \mathrm{L}$. During the December 1993 high-flow sampling, DOC values were considerably higher, 3.4 and $3.8 \mathrm{mg} / \mathrm{L}$ at NUBWC and NURCR, respectively. SOC values were only marginally higher at high flow (0.6 and $0.8 \mathrm{mg} / \mathrm{L}$, at the two sites respectively). No data are available for comparison at other sites in the basin or in previous years; however, total organic carbon (TOC) was measured in the fall of 1994, in water overlying spawning beds in bypass reaches downstream from Soda Springs Reservoir, the Slide Creek and Clearwater No. 2 diversion structures and in the full-flow reaches downstream of the Lemolo No. 2 powerhouse and in the Wild and Scenic reach. TOC concentrations were generally low (median $0.9 \mathrm{mg} / \mathrm{L}$ ) and ranged from less than the detection limit to $3.1 \mathrm{mg} / \mathrm{L}$ (PacifiCorp, 1995a, volume 21).

\section{Trace elements and pesticides in water-Although} filtered-water trace-element concentrations were near the minimum reporting levels (MRL), arsenic $(1 \mu \mathrm{g} / \mathrm{L})$, barium $(3 \mu \mathrm{g} / \mathrm{L})$, manganese $(2 \mu \mathrm{g} / \mathrm{L})$, and aluminum (4-9 $\mu \mathrm{g} / \mathrm{L})$ were consistently detected in the four low-flow samplings. No unfiltered samples were analyzed for trace elements. As with major ions, concentrations of trace elements were essentially identical at NUBWC during the initial samplings in 1993. Interestingly, arsenic was not detected at either NURCR or NUBWC during the high-flow sampling in December 1993. Barium and manganese were essentially unchanged at high flow. Additional trace elements detected at high flow were copper $(2 \mu \mathrm{g} / \mathrm{L})$ and nickel $(1 \mu \mathrm{g} / \mathrm{L})$. Aluminum $(153-167 \mu \mathrm{g} / \mathrm{L})$ and iron $(87-100 \mu \mathrm{g} / \mathrm{L})$ were substantially higher at high flow, which could be a result of colloids (not present at low flow) passing through the $0.45-\mu \mathrm{m}$ pore-size filters. Zinc was detected at both sites in 1993 during both low and high flow. After correcting for the possible contamination noted previously (see Quality Assurance section), zinc concentrations were above the MRL only in the two samples (low and high flow) at NUBWC in 1993. Because of the lack of detections in any other trace-element samples, it is unknown whether the reported zinc concentrations at NUBWC were the result of contamination. Mercury, which is found in geologic formations in other parts of Douglas County and in the nearby Coast Fork Basin of the Willamette River, was not detected at the relatively high MRL of $0.1 \mu \mathrm{g} / \mathrm{L}$.

Of the detected trace elements, arsenic is perhaps the most significant because it is a human carcinogen, and because the river is used for drinking water by some people. On the basis of few data (detections of $1 \mu \mathrm{g} / \mathrm{L}$ in each of four low-flow samples), there may be a concern for human health in the basin. The U.S. Environmental Protection Agency's (USEPA's) Risk Specific Dose Health Advisory for arsenic, a cancer-oriented advisory level that is based on a lifetime consumption rate of 2.1 quarts of water a day for a 154-pound adult, and that indicates a 1:10,000 risk level, is $2.2 \mu \mathrm{g} / \mathrm{L}$. The USEPA's criterion for water and fish consumption, which assumes consumption rates of 2.1 quarts of water per day and 1.6 ounces of fish per week for a 154-pound adult, and uses the same 1:10,000 risk level, is $0.22 \mu \mathrm{g} / \mathrm{L}$ (U.S. Environmental Protection Agency, 1996). Given the $1 \mu \mathrm{g} / \mathrm{L}$ arsenic concentration measured in water, the cancer risk level can therefore be considered to be between 1:5,000 and 1:20,000, for 
people whose drinking-water source is the North Umpqua River and who regularly eat fish from the river. These results do not necessarily mean that similar concentrations will be found downstream or in treated water.

The source for arsenic in North Umpqua River water is unknown; however, arsenic is commonly derived from geologic sources in volcanic regions such as the North Umpqua River Basin. Although concentrations in bed sediment were lower in the samples from NURCR and NUBWC (see below) than in sediment samples from four small tributaries to Steamboat Creek, there were no detections of arsenic in low-flow samples from the Steamboat Creek sites (Rinella, 1998). Likewise, there were no detections of arsenic in water samples collected from five sites within the hydroproject area in October 1993 (PacifiCorp, 1995a, volume 21). Additional testing of water from other tributaries, or farther up the main stem, and investigation of arsenic concentrations in well water, may be warranted to determine arsenic sources to the river.

Of the 87 pesticides analyzed in high-flow samples from the Wright Creek and Rock Creek sites in December 1993, none were detected. Historical records indicate that the herbicides simazine (Princep), atrazine, 2,4-D, 2,4,5-T, and triclopyr had been periodically applied within the forest for vegetation management along roads and after clear cutting; however, that practice was discontinued in the 1990's. Because of the lack of detections, sampling for pesticides was not repeated after December 1993.

\section{Trace elements and chlorinated compounds in bed} sediment-Trace-element concentrations in bed sediment, which were determined primarily in the fine fraction (less than $63-\mu \mathrm{m}$ diameter grain size), indicate a possible slight enrichment by phosphorus from natural sources (Appendix C); however, data sets with which to make a comparison are scarce. Phosphorus constituted roughly 0.16 grams per 100 grams of stream sediments $(0.16 \%)$ in the North Umpqua River during 1993. One source of streambed-sediment data for comparison is the USGS National Water-Quality Assessment (NAWQA) Program, from which data are available from the Willamette River Basin just north of the North Umpqua River Basin (Frank Rinella, U.S. Geological Survey, unpub. data, 1997), the Yakima River Basin in the eastern Cascades of Washington (Fuhrer and others, 1994), and a summary of NAWQA studies nationwide (Karen Rice, U.S. Geological Survey, written commun., 1998). Phosphorus in streambed sediments from the North Umpqua River was roughly equivalent to the 80th, 90th, and 75th percentile concentrations of phosphorus in these data sets, respectively. Concentrations in the streambed sediments also were equivalent to the 95th percentile of phosphorus concentrations in western soils, based on a comparison with a large data base of trace-element concentrations in soils across the Western United States (R.C. Severson, U.S. Geological Survey, written commun., 1987, from data presented by Shacklette and Boerngen, 1984). The western soils data, however, are for dry soils rather than streambed sediments, and are based on a larger size fraction (less than $2 \mathrm{~mm}$ ) than the streambed-sediment samples from the North Umpqua. Nonetheless, these results suggest that phosphorus tends to be somewhat elevated in streams draining the Cascade Range and the North
Umpqua River Basin, in agreement with previous conclusions based on water-quality data in the hydroproject area.

As with the water samples, mercury was not detected in the bed sediments. Aside from phosphorus, the only other elements that had concentrations consistently exceeding median concentrations in the Willamette, Yakima, and national NAWQA data sets were antimony, selenium, and arsenic.

Several of the observed trace-element concentrations in bed sediment exceeded available reference levels for potential adverse effects to benthic organisms. Lowest Effect Levels adopted by New York State (New York State Department of Environmental Conservation, 1994) and the Ontario Ministry of the Environment (Persuad and others, 1993) for arsenic, chromium, copper, manganese, and nickel are 6, 26, 16, 460, and 16 milligrams per kilogram ( $\mathrm{mg} / \mathrm{kg}$ ), respectively; average concentrations for these elements in the North Umpqua River sediment were $8.6,61,24,835$, and $44 \mathrm{mg} / \mathrm{kg}$, respectively. In addition, chromium was higher than the guideline value $(20 \mathrm{mg} / \mathrm{kg})$ used by the State of Oregon to evaluate disposal of dredge material (Oregon Department of Environmental Quality, 1990). Of these trace elements that are potentially elevated in bed sediments, only arsenic, copper, manganese, and nickel were detected occasionally in the water-column samplings for trace elements in filtered water (Appendix C); however, concentrations were below water-column guidelines. Detections of arsenic at relatively high concentrations in the bed sediments reinforces the validity of the detections in the water column. Arsenic is also found in relatively high concentrations in ground water in the adjacent forested watersheds of the Willamette Valley near Eugene (Hinkle, 1997), and it is likely derived from geologic sources in the volcanic rocks of the Cascade Range.

No chlorinated organic compounds were detected in the bed-sediment samples. This is most significant with respect to PCBs because PCBs were used historically as insulating compounds in electrical transformers and could potentially have been used in or released from the hydroelectric facilities (PacifiCorp, 1995a, volume 21).

\section{Nutrients}

The major nutrients of concern in algal or eutrophication studies are typically nitrogen, phosphorus, and sometimes carbon. The dissolved inorganic forms, which include ammonium nitrogen $\left(\mathrm{NH}_{4}{ }^{+}\right)$, nitrite plus nitrate nitrogen $\left(\mathrm{NO}_{2}{ }^{2-}+\mathrm{NO}_{3}{ }^{-}\right)$, and orthophosphate $\left(\mathrm{PO}_{4}{ }^{3-}\right)$ are generally considered to be the most available for algal growth. From a thermodynamic standpoint, the preferred forms are $\mathrm{NH}_{4}{ }^{+}$and $\mathrm{PO}_{4}{ }^{3-}$; however, other forms, such as polyphosphates and organically bound nitrogen, are assimilated in various amounts depending on the nutrient status of the water (Wetzel, 1983). In this report, the combination of orthophosphate, some dissolved polyphosphates, and colloidal phosphorus, which are not distinguished in the analytical procedures used, is referred to as soluble reactive phosphorus (SRP). Typically, SRP is dominated by orthophosphate.

Although the growth of algae and other aquatic organisms can be limited by any one of many physical, chemical, and biological factors (especially light, available substrate, temperature, 
and carbon), the lack of available nitrogen or phosphorus is most often cited as the limiting factor (Welch, 1992). Nutrient limitation occurs if demand for nutrients exceeds available supply, whereas colimitation occurs when two or more resources are simultaneously limiting. In the North Umpqua River Basin, initial data analysis indicated that inorganic nitrogen concentrations were potentially low enough to be limiting (U.S. Geological Survey, 1994, 1995; PacifiCorp, 1995a).

Nitrogen-Nitrogen, in any form, was mostly nondetectable during the July 1995 synoptic survey. Of the 32 water samples from all sites (including those collected by PacifiCorp), there were a total of 5 detections for TKN, and 4 detections each for $\mathrm{NH}_{4}{ }^{+}$and $\mathrm{NO}_{3}{ }^{-}$. In the main stem of the Wild and Scenic reach, only one sample (the second sample at COPEG) had detectable nitrogen $\left(14 \mu \mathrm{g} / \mathrm{L}\right.$ of $\left.\mathrm{NH}_{4}{ }^{+}\right)$. Most of the detected nitrogen was from six sites within the hydroproject area (Appendix A, table A1; Appendix D, table D1). These sites are CLRAS, LEM1T, TOKET, LAKEM, FISHA, and LEM2B. Of these concentrations, all but a high TKN observed at LEM2B were close enough to the analytical detection limits that they could either represent actual concentrations or false detections. The reported TKN concentration at LEM2B was $1,600 \mu \mathrm{g} / \mathrm{L}$, a value that is higher than any previously documented by PacifiCorp in the North Umpqua River Basin. Detections of nitrogen in the tributaries downstream of the hydroproject area were limited to 200 $\mu \mathrm{g} / \mathrm{L} \mathrm{TKN}$ at each of BOULM and SUSNM, $39 \mu \mathrm{g} / \mathrm{L}_{\text {of }} \mathrm{NH}_{4}{ }^{+}$at SUSNM, and $2 \mu \mathrm{g} / \mathrm{L}$ of $\mathrm{NH}_{4}{ }^{+}$at COPEM. The lack of detections is consistent with data from NURCR in samplings from 1993-94 (Appendix C). Concentrations were also low during those samplings, although $\mathrm{NO}_{3}{ }^{-}$and $\mathrm{NH}_{4}{ }^{+}$were detected at various concentrations below $20 \mu \mathrm{g} / \mathrm{L}$. In previous studies, TKN has been occasionally elevated, relative to concentrations reported in this study, downstream from Stump Lake (possibly attributable to springs in Stump Lake) and at depth in Lemolo and Toketee Lakes (T. Olson, PacifiCorp, written commun., 1997).

The scarcity of nitrogen in the waters of the North Umpqua River Basin implies that the algae in the river are potentially nitrogen limited, and hence any form of nitrogen could be important. To further explore this finding, uncensored data (including original NWQL data below the MRLs) for TKN and TDN samples submitted by the USGS were obtained from the NWQL upon special request. Such data are inherently variable and have a high degree of uncertainty associated with them because there is no quality assurance for sample concentrations below the MRLs. For concentrations between 100 and $200 \mu \mathrm{g} / \mathrm{L}$, however, there is a greater degree of confidence than for those less than $100 \mu \mathrm{g} / \mathrm{L}$ (Charles Patton, U.S. Geological Survey, written commun., 1996), and, in fact, the NWQL lowered the MRLs for TKN and TDN to $100 \mu \mathrm{g} / \mathrm{L}$ in 1997.

Using the uncensored TKN data qualitatively, the median concentration at the six most upstream sites sampled by the USGS (LAKEM, INLET, LEM1T, TOKET, SODAT, and BSODA) was estimated to be around $100 \mu \mathrm{g} / \mathrm{L}$, and the median TDN concentration was less than $50 \mu \mathrm{g} / \mathrm{L}$. The highest of these TKN concentrations, at LAKEM, was between 150 and 200 $\mu \mathrm{g} / \mathrm{L}$, which supports findings from previous investigations that have consistently reported concentrations of organic nitrogen between 200 and $600 \mu \mathrm{g} / \mathrm{L}$ in Lake Creek (Salinas and Larson,
1995; PacifiCorp, 1995a, volume 23; Dallas Hughes, U.S. Forest Service Memorandum to Pacific Power and Light, written commun., 1971). Uncensored TKN data from SODAT and TOKET were also somewhat high (estimated to be between 100 and 150 $\mu \mathrm{g} / \mathrm{L})$. For main-stem sites downstream from the hydroproject area, the median estimated TKN concentration was between 50 and $100 \mu \mathrm{g} / \mathrm{L}$, with the highest occurring during the second sampling at COPEG. Three sites immediately downstream of impoundments, LEM1T, TOKET, SODAT, and to a lesser extent COPEG, were among those likely to have concentrations of TKN greater than $100 \mu \mathrm{g} / \mathrm{L}$, an observation that will be explored later in the report.

Phosphorus-Phosphorus is much more common in the North Umpqua River Basin than inorganic nitrogen (fig. 5), although concentrations may be considered low compared to concentrations in streams with substantial anthropogenic inputs. TP, TDP (not shown in fig. 5), and SRP were detected in all of the

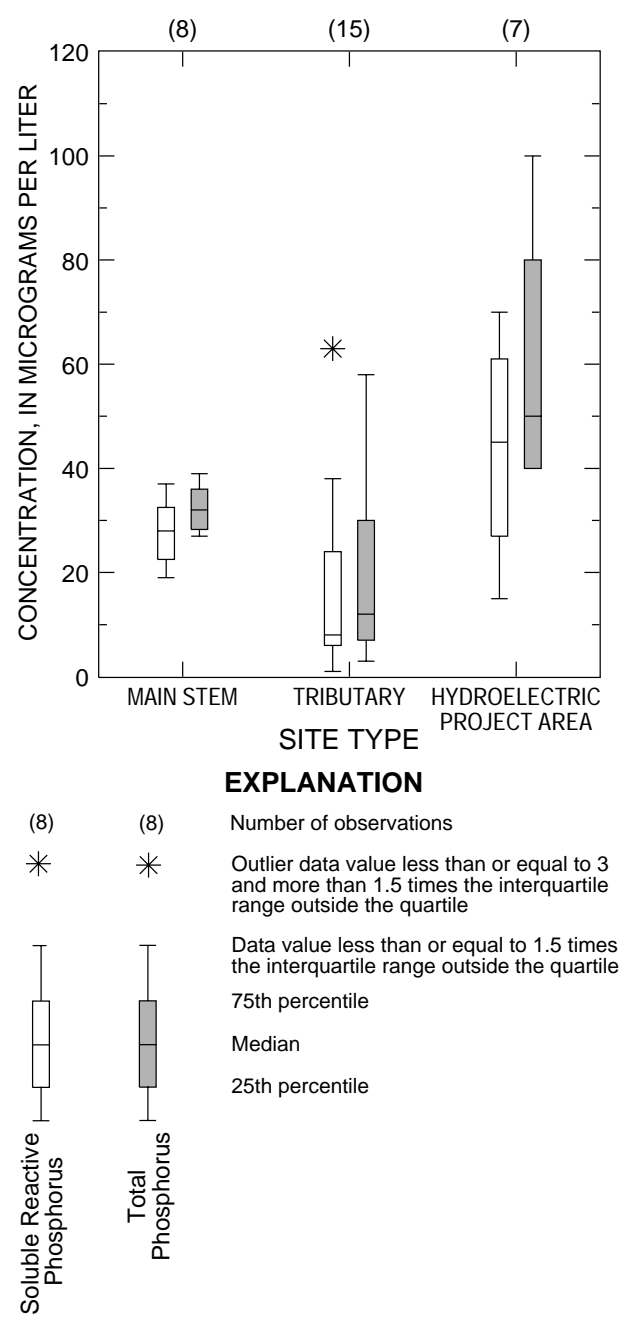

Figure 5. Distributions of soluble reactive and total phosphorus concentrations at different site types in the North Umpqua River Basin, Oregon, July 1995. (Main-stem sites are those in the North Umpqua River downstream of Soda Springs Reservoir, not including BSODA. Sites in the hydroelectric project area but unaffected by project operations [INLET, LAKEM, CLRAS, and FISHA] were included as tributary sites.) 
samples from July 1995, with median TP concentrations of 32, 12 , and $50 \mu \mathrm{g} / \mathrm{L}$ in the main stem, tributary, and hydroproject area, respectively. Concentrations at the main-stem sites had the least variability and were intermediate between concentrations in the tributaries and within the hydroproject area. The relatively high concentrations observed in the hydroproject area are probably caused by a combination of factors, including the different geomorphic origins of the water (a hydrogeologic unit located in Quaternary-Tertiary volcanic rocks) compared with those of the tributaries below the hydroproject area that originate at lower elevations. Additional factors resulting in increased concentrations could include in-reservoir nutrient processes, resuspension resulting from hydroproject operations, or erosion problems in the hydroproject area (PacifiCorp, 1995a, volume 42). The possible high biases in PacifiCorp's data (see the Quality Assurance section) may also have contributed to sites in the hydroproject area having higher reported concentrations of phosphorus. The range in phosphorus concentrations was equivalent between the tributary and hydroproject sites. This is largely due to the inclusion of INLET (with high concentrations) as a tributary site, although Rock Creek (ROCKM) and Susan Creek (SUSAM) each had relatively high concentrations that contributed to the spatial variability of tributary phosphorus; in the case of Rock Creek, the high concentrations could have resulted, in part, from the fish hatchery just upstream of the mouth.

Phosphorus concentrations in the main stem showed a slight but steady decrease in a downstream direction from Soda Springs Reservoir to Glide (fig. 6). This observation is based on the analysis of the initial sample at COPEG and its relative agreement with phosphorus concentrations from the nearby sites at BSODA and SODAT. However, if the decrease of $12 \mu \mathrm{g}$ P/L between the first and the second sample at COPEG accurately represents temporal variability in the water released from Soda Springs, then there is more uncertainty regarding the concentrations measured at each main-stem site, and downstream changes in phosphorus concentrations are more difficult to confirm. The variable, and often higher, TP concentrations at the hydroproject area sites upstream of BSODA are also evident in figure 6. SRP concentrations in the study area had a similar pattern to those for TP.

Although slight, the decreases in phosphorus concentrations in the main stem indicate potential phosphorus uptake by the benthos, rather than dilution by tributary inflows. Loading calculations indicate a small decrease in the SRP load between Soda Springs and the terminus of the Wild and Scenic reach at NURCR. The gross load change, accounting for tributary inputs, is 28.4 kilograms per day or a loss of approximately $21 \%$ of the original incoming load of 82 kilograms per day from Soda Springs Reservoir. Given the apparent nitrogen limitation of the river system, any phosphorus decrease is important, as it suggests uptake and active algal growth, in confirmation of the observed algal coverage on rocks in the river. Although at least a moderate uptake of phosphorus from the algal growth might be expected, these aspects cannot be verified from the data collected in July 1995 only.

The effect of the reservoir operations on temporal variability in nutrient concentrations in the Wild and Scenic reach can be evaluated by examination of reconnaissance data collected during 1993-94 (table C3 in Appendix C). In 1993 and 1994, sam- ples were collected under normal summer flow conditions, which commonly included daily flow fluctuations from Soda Springs Reservoir (fig. 1). In these circumstances, with potential short-term changes in the characteristics of water entering and being released from Soda Springs Reservoir (for example, originating in the upper North Umpqua River, Clearwater River, or Fish Creek watersheds), and resuspension of sediments or algal sloughing due to unstable main-stem flow, it is reasonable to expect higher or more variable phosphorus concentrations or more detections for nitrogen. Indeed, concentrations of $\mathrm{NH}_{4}{ }^{+}$ were as high as $30 \mu \mathrm{g} / \mathrm{L}$ at NURCR and $10 \mu \mathrm{g} / \mathrm{L}$ at NUBWC during September 1993, and were lower, but detectable, during July and September at NURCR in 1994. As in 1995, $\mathrm{NO}_{3}{ }^{-}$was not detected during 1993-94 at either site. Meanwhile, phosphorus concentrations were somewhat lower during 1995 than in previous years. TP was 50 and $40 \mu \mathrm{g} / \mathrm{L}$ at NUBWC and NURCR, respectively, during 1993 and 1994, whereas it was $32 \mu \mathrm{g} / \mathrm{L}$ at both sites in 1995. Other factors that could have contributed to higher concentrations of both nitrogen and phosphorus during 1993 and 1994 include the possibility that upstream algal community metabolism is less in September and therefore requires less nutrients for cell maintenance. Algal decay and sloughing, and nutrient remineralization also could account for the higher fall concentrations.

There is a potential for nutrient enrichment from sewage in seeps from failed septic systems near Toketee Lake (Memo from Dallas Hughes, U.S.Forest Service, to Pacific Power and Light, written commun., 1971), as mentioned previously. The sampling site downstream of Toketee Lake (TOKET) was one of the sites in the hydroproject area at which TKN was detected. That a portion of this source could still be contributing nutrients to Toketee Lake is consistent with the abundance of eutrophic and heterotrophic algal taxa that was observed below the lake in July 1995 (see below).

\section{Algal Conditions}

Algae (particularly diatoms) are sensitive to environmental conditions (habitat and water quality) in freshwater environments (Pan and others, 1996; Kutka and Richards, 1996). Because they have short life cycles, algae respond quickly to environmental change and integrate conditions over time, as they remain attached to the substrate. Algae are particularly sensitive to changes in nutrient concentrations, $\mathrm{pH}$, trace-element concentrations, light, temperature, turbidity, and flow. Ecological requirements and pollution tolerances (autecologies) of various taxa have been determined (see Schoeman, 1973; Lowe, 1974; Dam and others, 1994), which together with the use of more traditional measurements of biomass, has greatly facilitated the use of peri-

phyton communities to infer physical or chemical conditions in rivers (Round, 1991; Bahls, 1993; Gregory, 1993; Dixit and Smol, 1994; Leland, 1995; Pan and others, 1996; Cuffney and others, 1997). The following section makes use of both biomass measurements and the autecological information provided by algal communities in order to integrate physical and chemical data with biological data in the North Umpqua River Basin. 


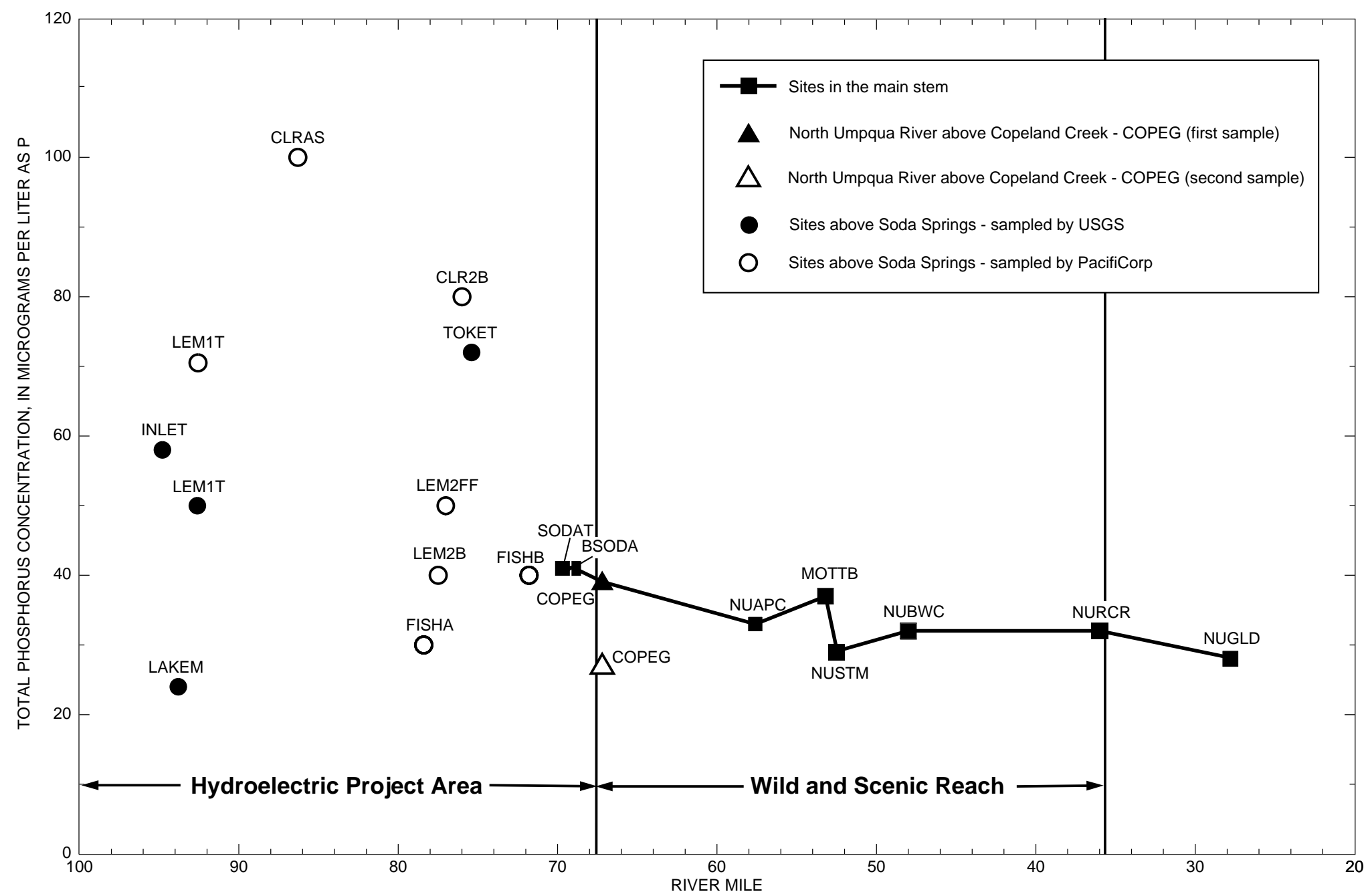

Figure 6. Total phosphorus concentrations in the North Umpqua River Basin, Oregon, July 1995. (Two samples taken 3 days apart from the North Umpqua River above Copeland Creek are shown to indicate temporal variability. Tributary sites downstream of Soda Springs Reservoir are not shown. Refer to table 4 for a listing of sites, acronyms, and river miles.) 


\section{Periphyton Biomass}

The different measures of algal biomass (chlorophyll $a$, AFDM, and cell biovolume) were generally in agreement and produced similar patterns among sites (fig. 7). Pearson correlation between periphyton chlorophyll $a$ and AFDM was significant and positive $\left(R^{2}=0.93 ; p<0.001\right)$, whereas measures of algal biovolume were more variable, relative to chlorophyll $a$ and AFDM, at some sites (TOKET, BSODA, and STEABB). These sites were unique in their high abundance of filamentous green algae or epithemiacean diatoms (Appendix E, table E2).

Periphytic algal growth was highest at sites within the hydroproject area, with highest measured abundance generally occurring at BSODA, downstream from the lowermost powerhouse (fig. 7). Visual observations in September 1996 indicated that growth at this site was representative of conditions downstream from each of the eight powerhouses. Long strands of filamentous green algae covered the substrate immediately below each powerhouse. In July 1995, chlorophyll $a$ and AFDM at BSODA were $209 \mathrm{mg} / \mathrm{m}^{2}$ and $68 \mathrm{~g} / \mathrm{m}^{2}$, respectively, which exceeds the concentration range (100-150 $\mathrm{mg} / \mathrm{m}^{2}$ chlorophyll $a$ ) suggested by Welch and others $(1988,1989)$ and Biggs (1996) to indicate nuisance conditions. The "heavy growth" quality assurance sample collected from BSODA to evaluate "worst case" abundances of periphyton contained $440 \mathrm{mg} / \mathrm{m}^{2}$ chlorophyll $a$, which far exceeded this nuisance level. Hydroproject area sites located in bypass reaches downstream from Lemolo and Toketee dams (LEM1T and TOKET) had the next highest amounts of chlorophyll $a$. Decaying periphyton covered the heavily embedded cobble substrate at these sites.

Downstream from BSODA, channel coverage by periphyton at the higher flow main-stem sites was reduced and more variable, forming localized patches of dense growth. All three measures of algal abundance shown in figure 7 indicated that at COPEG, 2 miles below BSODA, abundance was much less than at the hydroproject area sites. Given the high algal abundance at BSODA, it is possible that the sharp decline downstream at COPEG was in response to reduced nutrient availability resulting from the uptake of nutrients, particularly nitrogen, by algae between BSODA and COPEG. This interpretation is supported by an accompanying increase in nitrogen fixing algal taxa (Nostocaceae and Rivulariaceae) at COPEG. Chlorophyll $a$ and AFDM concentrations in the North Umpqua River downstream of Steamboat Creek (at NUSTM and NURCR) were intermediate between those observed at BSODA and at COPEG.

Water chemistry, light availability, and algal biomass at the two sites on the major tributaries to Lemolo Lake, LAKEM and INLET, were distinctly different (Appendix A, table A1; and Appendix D, table D1). LAKEM, which is approximately 10 miles downstream of Diamond Lake on Lake Creek, had lower light availability (58\% open canopy) than INLET (97\% open canopy), owing to the smaller stream width and dense riparian vegetation, and a lower phosphorus concentration $(11 \mu \mathrm{g} / \mathrm{L})$. Algal chlorophyll $a$ at LAKEM $\left(11 \mathrm{mg} / \mathrm{m}^{2}\right)$ was lower than at INLET $\left(82 \mathrm{mg} / \mathrm{m}^{2}\right)$, despite warmer afternoon water temperatures at LAKEM $\left(16.6^{\circ} \mathrm{C}\right)$ compared with those at the springfed $\operatorname{INLET}\left(8.8^{\circ} \mathrm{C}\right)$. These data suggest that nutrients and light, and not temperature, had a greater importance in controlling algal biomass at those sites.
Substrate embeddedness, measured according to USGS NAWQA protocols (Meador and others, 1993), and algal coverage at INLET were also greater than at LAKEM. The greater algal abundance and lower flow velocity at INLET $(1.5 \mathrm{ft} / \mathrm{s})$ compared with those at LAKEM ( $2.5 \mathrm{ft} / \mathrm{s})$ may also allow for deposits of sediment to accumulate in the streambed, increasing the substrate embeddedness.

The periphyton communities at both Steamboat Creek sites, STEAM and STEABB, formed a thick golden biofilm that was unique compared with algal coverages at the other eight sites. Periphyton AFDM and algal biovolume at the upstream site (STEABB) were more than twice those observed at the mouth (STEAM). Chlorophyll $a$ at STEAM, however, was slightly higher than at STEABB.

Algal biomass in the North Umpqua River Basin, particularly at sites in the hydroproject area, appears to be somewhat higher than in the other major streams in the Western Cascades. Gregory (1993) reported summertime periphyton chlorophyll $a$ concentrations of 76,72 , and $21 \mathrm{mg} / \mathrm{m}^{2}$ for the McKenzie, Santiam, and Clackamas Rivers, respectively. In the Bull Run watershed, in the northern Oregon Cascades, Clifton (1985) found that chlorophyll $a$ concentrations on plastic slide substrates averaged $17.1 \mathrm{mg} / \mathrm{m}^{2}$, with a maximum chlorophyll $a$ concentration of 68 $\mathrm{mg} / \mathrm{m}^{2}(\mathrm{~N}=97)$. Median cell densities in the Bull Run watershed, which is considered a pristine watershed and is the drinkingwater source for the city of Portland, were more than 2 orders of magnitude lower than those found in the North Umpqua River Basin (Appendix E, table E3). The streams sampled in the Bull Run watershed were of a lower stream order (2-3) than those sampled in the North Umpqua River Basin and would be expected to have lower algal biomass (Vannote and others, 1980); nevertheless, these data reinforce the observation that algal biomass is higher at some locations in the North Umpqua River than in many streams of similar order and aspect draining westward from the Cascade mountains.

\section{Phytoplankton Chlorophyll a}

Water-column (suspended) chlorophyll $a$ concentrations at each of six sites sampled in July 1995 were low: the highest chlorophyll $a$ concentration $(2.1 \mu \mathrm{g} / \mathrm{L})$ occurred at LAKEM, which receives water from eutrophic Diamond Lake 10 miles upstream (Salinas and Larsen, 1995). Suspended chlorophyll $a$ concentrations downstream from Lemolo Lake $(1.5 \mu \mathrm{g} / \mathrm{L}$ at LEM1T) were similar to that found in September 1994 by PacifiCorp (1995a, volume 22). Water-column chlorophyll $a$ at LEM1T was probably periphyton-derived, rather than from actual phytoplankton algae. Although no species data were collected to confirm this, (1) flows in the bypass reach downstream from Lemolo Dam result from hypolimnetic release within the lake (table 1), (2) no planktonic algal forms were detected in the periphyton sample from LEM1T, and (3) the canyon in which LEM1T is located is well shaded (39\% open), which helps limit the survival of phytoplankton.

\section{Periphyton Species Composition}

A total of 99 distinct algal taxa from 5 Divisions were identified from 10 samples collected in 1994-95 (table 9). Diatoms 


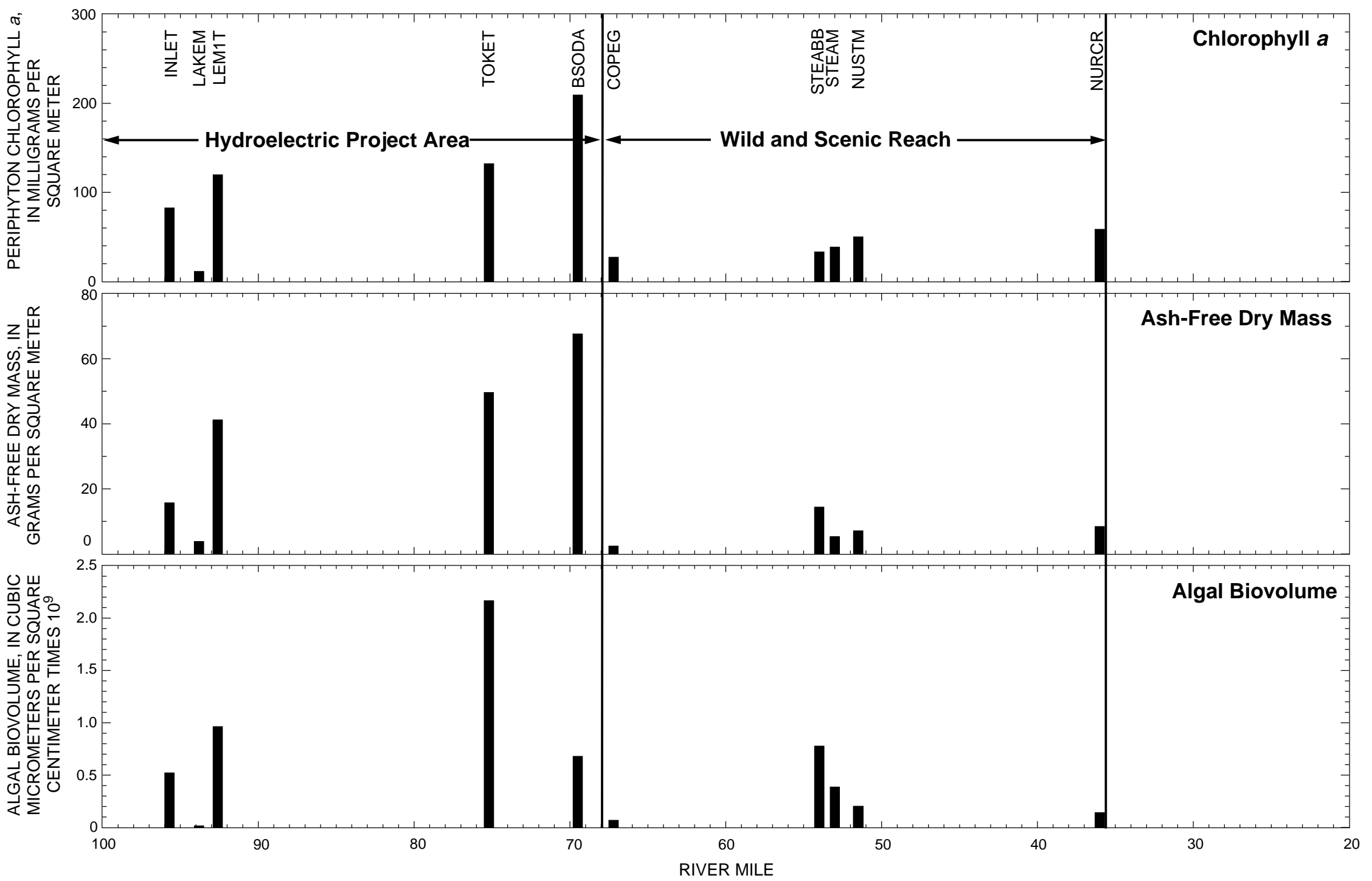

Figure 7. Periphyton abundance at 10 sites in the North Umpqua River Basin, Oregon, July 1995. (Site acronyms are listed in table 4. Tributaries [INLET, LAKEM, and STEAM] are positioned where they join the main stem North Umpqua River. STEABB, an upstream site on Steamboat Creek [river mile 11.9], is also included.) 
Table 9. Number of algal taxa in major Divisions from 10 sites sampled in the North Umpqua River Basin, Oregon, 1994-95

[Algal taxa are unique levels of taxonomic identification]

\begin{tabular}{lc}
\hline \multicolumn{1}{c}{ Algal Division (and common name) } & $\begin{array}{c}\text { Number } \\
\text { of taxa }\end{array}$ \\
\hline Bacillariophyta (diatoms) & 98 \\
Cyanophyta (blue-green algae) & 12 \\
Chlorophyta (green algae) & 5 \\
Rhodophyta (red algae) & 1 \\
Chrysophyta (golden algae) & 1 \\
\hline Total number of taxa & 117 \\
\hline
\end{tabular}

represented $84 \%$ of the taxa, followed by blue-green algae $(10 \%)$, green algae (4\%), and red and golden algae (less than $1 \%$ each). Species richness (number of taxa) per site ranged from 1834. Species richness, however, increases with the numbers of cells enumerated. Because samples from three of the sites (COPEG, STEAM, and NURCR) were counted by the Philadelphia Academy of Natural Sciences (300 cells counted) compared to 100 "algal units" counted in samples from the other 7 sites by Aquatic Analysts, species richness values are not comparable among sites.

Among all sites, diatoms and blue-green algae accounted for most of the algal biovolume (more than 99\%) and density (more than 96\%). Blue-green algae were most abundant at the three main-stem sites (COPEG, NUSTM, NURCR) and STEAM, making up more than $69 \%$ of the cell densities. Blue-green algae were observed at all sites except TOKET and LEM1T, where diatoms (primarily) and green algae were found. Blue-green algae are small and make up a relatively smaller proportion of the cell biovolume compared to cell densities. For example, blue-green algae comprised $97 \%$ of the density at COPEG, primarily Nostoc sp., but only $51 \%$ of the biovolume. Many of the blue-green algae observed in this study have the ability to fix atmospheric nitrogen (Fogg and others, 1973) — a factor that is consistent with the apparent nitrogen limitation in most of the study area.

Two diatom genera in the Epithemiaceae family (Epithemia and Rhopalodia) were particularly abundant at six sites (BSODA, STEABB, STEAM, NUSTM, NURCR, and INLET). As mentioned previously, all species in this family have endosymbiotic coccoid blue-green algae that live inside the host diatoms and fix molecular nitrogen (Bahls and Weber, 1988; DeYoe and others, 1992); their presence may indicate nitrogen limitation (Power, 1990). Conditions that favor the growth of nitrogen-fixing taxa include low concentrations of inorganic nitrogen and relatively high concentrations of dissolved phosphorus, resulting in low N:P ratios (Fairchild and others, 1985; Stockner and Shortreed, 1988). However, two other diatom genera (Achnanthidium and Cocconeis) that can indicate nutrient enrichment (Fairchild and others, 1985) were present.

Filamentous green algae were detected in samples from INLET, TOKET, and LEM1T. On the basis of field observations, the filaments of green algae at TOKET were decaying and may have been underrepresented in the cell counts from this site, although sampling was accomplished by means of a Hess sampler. No filamentous green algae were identified in the sample from BSODA either, although field observations indicated that growth of these forms were present, an observation that is consistent with the high biomass at this site.

\section{Autecological Guilds}

Autecological guilds are groups of taxa that have special attributes or that can be used as indicators of environmental conditions. Guilds identified in this study include nitrogen fixers, facultative nitrogen heterotrophs (which have the ability to assimilate organic nitrogen as a source of both nitrogen and energy), eutrophic taxa (indicative of waters having high nutrient content), oligotrophic taxa (indicative of waters having low concentrations of nutrients), alkaliphilic taxa (occurring at $\mathrm{pH}$ values near 7, with best development above 7), and cold-water taxa (indicative of water temperatures below $15^{\circ} \mathrm{C}$ ) (Lowe, 1974; Dam and others, 1994). A summary of the percent biovolume, percent density, and numbers of taxa in each autecological guild from all 10 sites is presented in table 10. Note that some species are in more than one guild (for example, some nitrogen heterotrophic taxa also are classified as eutrophic, see Appendix E). For this reason the sum of the percentages may exceed $100 \%$ when percent abundances of different guilds are compared to illustrate gross differences or patterns.

\section{Spatial Variability}

All sites sampled contained a relatively high proportion of alkaliphilic taxa (23-97\% relative biovolume); whereas eutrophic taxa, although less abundant, were also found in moderate-to-high proportions (10-71\% relative biovolume). Nitrogen-fixing taxa were also abundant, particularly at main stem and Steamboat Creek sites, whereas eutrophic and nitrogen heterotrophic taxa were more abundant at the hydroproject sites, particularly below impoundments (LEM1T and TOKET). Cold-water taxa were most abundant in the hydroproject area and at INLET, most likely as a result of greater shading and ground-water influences at those sites.

\section{Seasonal Variability}

Data from July 1995 provide indications about the algal community composition for only one point in time, and do not indicate successional patterns in the algal species. Data from NURCR during July and September 1994 can, however, provide an indication of temporal variability in species composition and algal biomass. Algal biovolume nearly doubled between the two sampling periods, whereas cell densities actually decreased (Appendix E, tables E2 and E3), indicating that average cell size increased. This phenomenon is best demonstrated by a shift in the types of nitrogen-fixing taxa from small blue-green nitrogenfixing forms (for example, in the Family Rivulariaceae) to the larger nitrogen-fixing diatoms (for example, in the Epithemia sp. and Rhopalodia gibba). Cells of Epithemia sp. may be as large as $3,000 \mu \mathrm{m}^{3}$, whereas cells of blue-green nitrogen fixers 
Table 10. Relative percent biovolumes and percent density by autecological guild, and dominant algal taxa at sites in the North Umpqua River Basin, Oregon, 1994-95

[Data from 1995 except where noted. Site acronyms are presented in table 4. Codominant guilds are shaded for each site. Relative percentages calculated from taxa biovolumes (cubic micrometers/square centimeter) or density (cells/square centimeter). NF, nitrogen fixers, NH, facultative nitrogen heterotrophs; E, eutrophic taxa; O, oligotrophic taxa; A, alkaliphilic taxa; C, cold-water taxa; \%, percent]

\begin{tabular}{|c|c|c|c|c|c|c|c|c|c|c|c|c|}
\hline \multirow{2}{*}{ Site } & \multicolumn{6}{|c|}{ Autecological guild } & \multicolumn{6}{|c|}{ Autecological guild } \\
\hline & NF & NH & $\mathbf{E}$ & 0 & A & C & NF & NH & $\mathbf{E}$ & 0 & A & C \\
\hline & \multicolumn{6}{|c|}{ Relative biovolume (\%) } & \multicolumn{6}{|c|}{ Relative density (\%) } \\
\hline All sites (1995) & 32 & 16 & 47 & 2 & 75 & 25 & 53 & 8 & 27 & 1 & 30 & 9 \\
\hline LAKEM & 13 & $<1$ & 16 & 40 & 23 & 9 & 2 & 2 & 28 & 21 & 24 & 8 \\
\hline INLET & 27 & 3 & 35 & 1 & 67 & 23 & 4 & 11 & 60 & 1 & 65 & 13 \\
\hline LEM1T & 10 & 18 & 71 & 6 & 62 & 21 & 1 & 24 & 74 & 3 & 68 & 7 \\
\hline TOKET & 2 & 31 & 56 & $<1$ & 88 & 53 & 1 & 19 & 67 & 1 & 81 & 47 \\
\hline BSODA & 78 & 4 & 13 & 2 & 86 & 1 & 20 & 17 & 50 & 3 & 64 & 3 \\
\hline COPEG & 81 & $<1$ & 10 & 2 & 34 & $<1$ & 97 & $<1$ & 1 & $<1$ & 1 & $<1$ \\
\hline STEAM & 56 & $<1$ & 12 & 0 & 27 & 2 & 77 & $<1$ & 2 & 0 & 2 & 0 \\
\hline STEABB & 90 & 1 & 62 & 0 & 97 & 0 & 54 & 12 & 33 & 0 & 73 & 0 \\
\hline NUSTM & 42 & 1 & 10 & 3 & 28 & $<1$ & 30 & 3 & 16 & 5 & 15 & 1 \\
\hline NURCR & 36 & 4 & 25 & 3 & 38 & 2 & 92 & 2 & 4 & 1 & 3 & $<1$ \\
\hline $\begin{array}{l}\text { NURCR } \\
\text { (July 1994) }\end{array}$ & 26 & 11 & 42 & 8 & 48 & 5 & 81 & 6 & 10 & 3 & 7 & $<1$ \\
\hline \multirow[t]{2}{*}{$\begin{array}{l}\text { NURCR } \\
\text { (Sept. 1994) }\end{array}$} & 33 & 13 & 51 & 4 & 60 & 14 & 60 & 16 & 24 & 2 & 20 & 1 \\
\hline & \multicolumn{12}{|c|}{ Dominant species in July 1995} \\
\hline LAKEM & \multicolumn{12}{|c|}{$\begin{array}{l}\text { Achnanthidium minutissimum, Gomphonema subclavatum, Oscillatoria sp., and } \\
\text { Epithemia } \mathrm{sp.}\end{array}$} \\
\hline INLET & \multicolumn{12}{|c|}{ Nostoc sp., Epithemia sp., Fragilaria construens, and Cymbella mexicana } \\
\hline LEM1T & \multicolumn{12}{|c|}{$\begin{array}{l}\text { Gomphoneis herculeana, Epithemia sp., Fragilaria construens, and Nitzschia } \\
\text { frustulum }\end{array}$} \\
\hline TOKET & \multicolumn{12}{|c|}{ Ulothrix sp., Diatoma hiemale mesodon, Fragilaria vaucheria, and Melosira varians } \\
\hline BSODA & \multicolumn{12}{|c|}{ Epithemia sp., Fragilaria construens, and Navicula cryptocephala } \\
\hline COPEG & \multicolumn{12}{|c|}{ Nostoc sp., Rivularia sp., and Epithemia sp. } \\
\hline STEAM & \multicolumn{12}{|c|}{ Rivularia sp., Oscillatoria sp., Nostoc sp., and Epithemia sp. } \\
\hline STEABB & \multicolumn{12}{|c|}{$\begin{array}{l}\text { Epithemia sp., Rhopalodia gibba, Achnanthidium minutissimum, and } \\
\text { Encyonema minutum }\end{array}$} \\
\hline NUSTM & \multicolumn{12}{|c|}{ Oscillatoria sp., Rivularia sp., and Nostoc sp. } \\
\hline NURCR & \multicolumn{12}{|c|}{ Rivularia sp., Nostoc sp., Gomphonema rhombicum, and Epithemia sp. } \\
\hline $\begin{array}{l}\text { NURCR } \\
\text { (July 1994) }\end{array}$ & \multicolumn{12}{|c|}{ Rivularia sp., Scytonema hoffmannii, and Epithemia sp. } \\
\hline $\begin{array}{l}\text { NURCR } \\
\text { (Sept. 1994) }\end{array}$ & \multicolumn{12}{|c|}{ Rivularia sp., Epithemia sp., Scytonema hoffmannii, and Gomphoneis herculeana } \\
\hline
\end{tabular}

are typically less than $50 \mu \mathrm{m}^{3}$. The total biovolume of eutrophic taxa and alkaliphilic taxa increased and the proportion of oligotrophic taxa decreased from July to September 1994 (table 10). Several eutrophic algal taxa (for example, Diatoma vulgare, Gomphoneis herculeana, Nitzschia frustulum, and Synedra ulna) increased 1.5 to 6 fold during this time period. Chlorophyll $a$ concentrations also were greater in July $1994\left(246 \mathrm{mg} / \mathrm{m}^{2}\right)$, than in September $1994\left(34 \mathrm{mg} / \mathrm{m}^{2}\right)$, and were intermediate to these in July $1995\left(58 \mathrm{mg} / \mathrm{m}^{2}\right.$ ) (Appendix C, table C3). AFDM, which was not determined in July 1994, was nearly four times higher in September $1994\left(28 \mathrm{~g} / \mathrm{m}^{2}\right)$ than in July $1995\left(8.4 \mathrm{~g} / \mathrm{m}^{2}\right)$.

\section{Cluster Analysis}

The TWINSPAN classification identified distinct groups of sites on the basis of biovolumes of algal taxa at each site (fig. 8). The relative percent biovolume for three select guilds (nitrogen fixers, facultative nitrogen heterotrophs, and eutrophic taxa) also are indicated. TWINSPAN split the original 10 sites into two groups: (1) 5 sites located in the hydroproject area, which were distinguished by the presence and (or) abundances of Melosira varians and Nitzschia dissipata (both are eutrophic taxa, and the former is also a nitrogen heterotroph), and (2) 5 sites located out- 


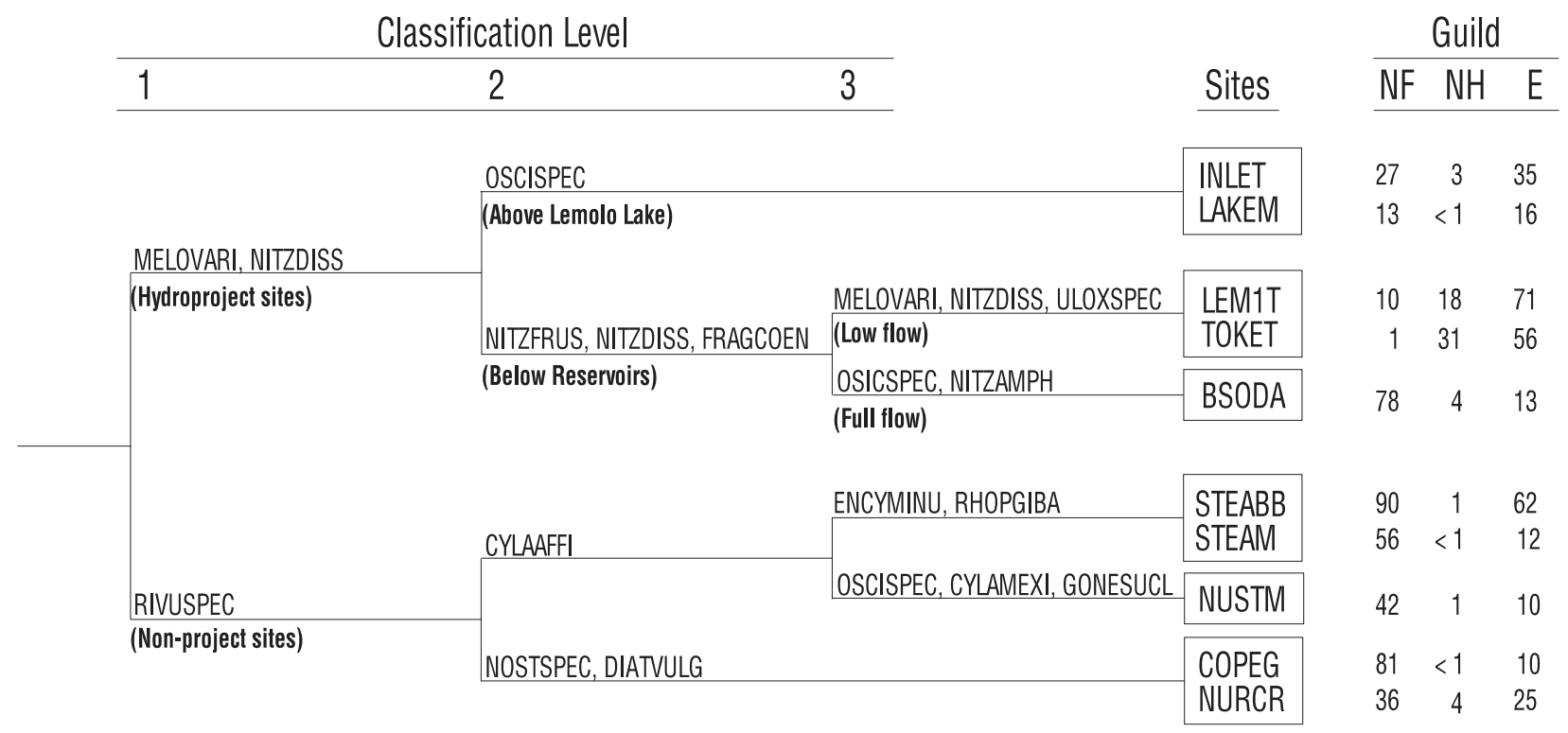

Figure 8. Cluster analysis from the Two-Way Indicator Species Analysis (TWINSPAN) and autecological guild summary for sites sampled for benthic algal community composition in the North Umpqua River Basin, Oregon, July 1995. (Indicator species are given for each classification level. Autecological guild data are given as percent relative biovolume [cubic micrometers/square centimeter] as follows; NF, nitrogen fixers, $\mathrm{NH}$, facultative nitrogen heterotrophs, and E, eutrophic taxa. Site acronyms are listed in table 4 and species are listed in Appendix E.)

side the hydroproject area (the 3 main-stem sites and the 2 sites in Steamboat Creek) that were dominated by the nitrogen-fixing Rivularia sp. The hydroproject sites were subsequently split into two groups: (1) sites upstream of Lemolo Lake (INLET and LAKEM), which had abundant Oscillatoria sp., and (2) three hydroproject sites that had a variety of eutrophic taxa (Nitzschia frustulum, Nitzschia dissipata, and Fragilaria construens). This second group was further divided into low-flow sites located downstream from dams (LEM1T and TOKET) and the full-flow site downstream from Soda Springs powerhouse (BSODA). The low-flow sites had the highest biovolumes of filamentous green algae, nitrogen heterotrophic, and eutrophic taxa (fig. 8).

The sites located outside the hydroproject area (that is, group 2 after the first split) were separated on the basis of abundance of the eutrophic species Cymbella affinis at the sites in Steamboat Creek (STEABB and STEAM) and NUSTM. This group of sites was distinct from COPEG and NURCR, which had a different assemblage (Nostocaceae spp. and Diatoma vulgare). Sites on Steamboat Creek were distinguished by Rhopalodia gibba and Encyonema minuta, whereas NUSTM was dominated by Oscillatoria sp. Note that Rhopalodia gibba is the one species classified as both a eutrophic indicator and a nitrogen fixer. Although these designations may seem contradictory, Rhopalodia gibba has been found to be facultative, capable of thriving in alkaline waters with high nutrient content, and adjusting in relative propor-

tion to the degree of nitrogen limitation by acting as a host to nitrogen-fixing coccoid blue-green algal cells (DeYoe and others, 1992).

\section{Ordination of Sites, Algal Taxa, and Environmental Variables}

The CCA triplot diagram in figure 9 shows a distribution of sites based on (1) the taxon abundance (biovolume) shown by taxon acronym and symbol, and (2) the environmental variables: dissolved, digested phosphorus (TDP), periphyton chlorophyll $a$ (Chl-a), flow (Flow), late afternoon $\mathrm{pH}$ (pH-pm), and late afternoon water temperature (Temp-pm), shown by the arrows. The length of the arrow is proportional to relative importance of the environmental variable in describing the algal communities, considering all sites where algae were collected. To evaluate site or taxon associations with a particular environmental variable, a perpendicular line is drawn from the site or taxon to the arrow. The relative position of the intersection of these lines indicates the association, with stronger positive correlations occurring at the tip of the arrowhead (or beyond) and stronger negative correlations occurring at the opposite end (not shown). For example, STEAM had relatively higher afternoon water temperatures, whereas flow at TOKET was relatively smaller, compared to the other sites. The algal taxa's association to the environmental variables can be examined in a similar fashion. The angle formed by the arrow and the primary (X) or secondary (Y) axis indicates the relative strength of the environmental gradient to each axis and therefore its importance in the separation of sites and species along that axis. For example, pH-pm and TDP were the most significant variables in describing variation along the primary axis, whereas Chl- $a$ and Temp-pm were the most significant variables in describing variation along the secondary axis.

In general, the CCA ordination produced the same two groups of sites as the TWINSPAN analysis and separated the hydroproject sites (LEM1T, INLET, and TOKET) from the main-stem and Steamboat Creek sites along the primary (X) axis. The hydroproject sites (excluding BSODA) were associated with high concentrations of phosphorus and chlorophyll $a$. These sites, particularly LEM1T, also were associated with eutrophic, nitrogen heterotrophic, and filamentous algal taxa. BSODA grouped with the main-stem sites, primarily because of the high flows and high abundances of Epithemia sp. 


\section{EXPLANATION}

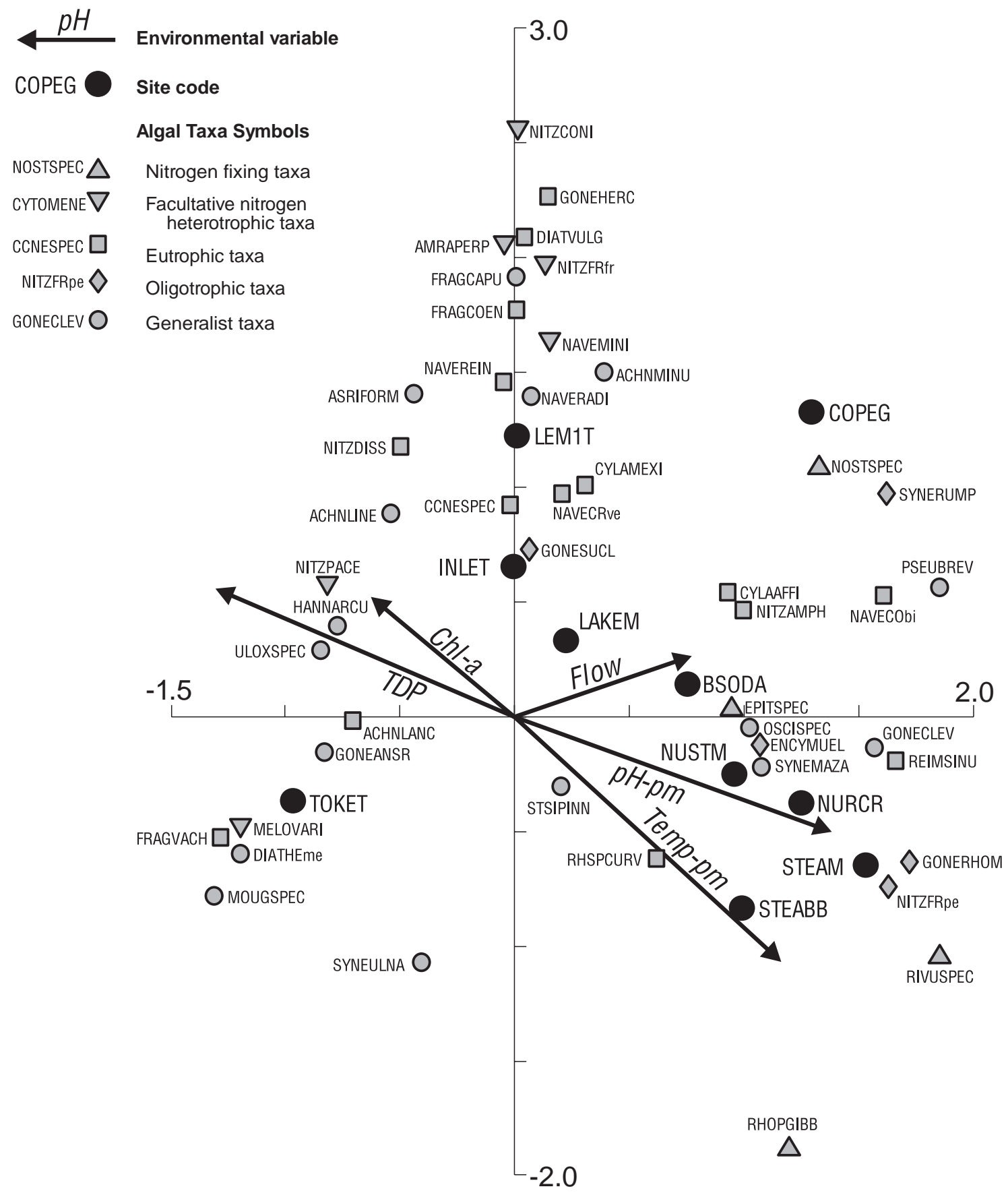

Figure 9. Canonical correspondence analysis (CCA) triplot of sites sampled in the North Umpqua River Basin, Oregon, July 1995, based on algal taxa (biovolumes) and environmental variables. (Site acronyms are listed in table 4 and species codes are listed in Appendix E. Environmental variables are defined as follows: TDP, dissolved, digested phosphorus; Chl-a, periphyton chlorophyll a; Flow, instantaneous discharge; $\mathrm{pH}-\mathrm{pm}$, late afternoon $\mathrm{pH}$; Temp-pm, late afternoon water temperature.)

STEABB was unique for its high abundance of the nitrogen fixer Rhopalodia gibba, and high water temperaturxe and $\mathrm{pH}$. NUSTM, NURCR, and STEAM were also associated with high $\mathrm{pH}$ values and the abundance of taxa that are intolerant of nutrient enrichment (Gomphonema rhombicum and Nitzschia frustulum perminuta). LAKEM was not strongly associated with main-stem or project sites, and plotted near the origin. This site had a poor fit, indicating that the environmental variables used in the ordination do not accurately represent species-environmental relations for LAKEM.

\section{Water Temperature, Dissolved Oxygen, and pH}

During the July 1995 synoptic survey, an attempt was made to measure water temperature, $\mathrm{DO}$, and $\mathrm{pH}$ at the extremes of their diel variations. With a few exceptions at minor tributaries, 
sites measured by the USGS were generally visited from 6:008:30 a.m. and from 3:00-6:30 p.m. to record their minimum and maximum values, respectively. PacifiCorp operated Hydrolabs at 10 sites during the week long survey (fig. 2), deployed to record these parameters hourly. These sites were located in the upper North Umpqua/Lemolo Lake drainage (INLET, LAKEM, LEM2B, LEM2FF, and TOKLKI), in the Clearwater River above Stump Lake (CLRAS) and near the bottom of the Clearwater No. 2 bypass reach (CLR2B), and in Fish Creek above the diversion dam (FISHA) and at the bottom of the bypass reach (FISHB). PacifiCorp also maintained a Hydrolab monitor downstream from Soda Springs Reservoir (at COPEG) during the survey. Results of the USGS and PacifiCorp (1995b) diel measurements are presented in figure 10. No morning data were available for the North Umpqua River near Glide (NUGLD). The times of the actual minimums and maximums appeared to be shifted towards the middle of the day at sites in the upper elevations, and hence the visitation times may not have adequately accounted for the actual minimum or maximum values. Data from sites that were logged with Hydrolabs by PacifiCorp are, in general, probably more reflective of the actual minimum and maximum values for the upper elevation sites.

Water temperature-Water temperatures exhibited a warming trend from the headwater sites to Glide (fig. 10), as would be expected because of the elevation change and the greater influence of ground water at the high elevation sites. In general, the magnitude of the diel temperature fluctuation also increased in a downstream direction. Although minimum temperatures in the main stem deviate somewhat from the temperatures observed at BSODA, the daily maximum temperatures increased from $13^{\circ} \mathrm{C}$ at BSODA to $21^{\circ} \mathrm{C}$ at NUGLD. This effect was particularly pronounced in the final 20 miles of the main stem, where the canyon begins to open up downstream from Steamboat Creek.

The highest afternoon temperatures occurred at the mouths of Steamboat Creek $\left(22.5^{\circ} \mathrm{C}\right)$ and the Little River $\left(22.0^{\circ} \mathrm{C}\right)$, which is consistent with their history of temperature problems related to logging; however, the diel change in temperature at these (and most other tributary) sites was limited to 1 or $2^{\circ} \mathrm{C}$. Tributary sites along the Wild and Scenic reach were, in general, slightly warmer than main-stem sites. The median diel temperature change at main-stem sites was $3^{\circ} \mathrm{C}$, although sites immediately downstream from Soda Springs (SODAT, BSODA, and COPEG) had only nominal temperature changes. All main-stem sites downstream from Steamboat Creek were warmer than $17.8^{\circ} \mathrm{C}$, the proposed State of Oregon 1996 temperature standard for streams with salmonids, by late afternoon. The presence of State Highway 138, which constrains the channel and helps limit riparian cover along the main stem, could partially contribute to this warming. The largest diel change observed at any site was the approximately $8^{\circ} \mathrm{C}$ swing recorded by PacifiCorp at LAKEM. The coldest water was observed at sites in the Clearwater River, which apparently has a large ground-water component upstream of Stump Lake, and upstream of Lemolo Lake at INLET (which is fed by both ground water and outflow from upper-elevation lakes).

The highest temperature observed at the fixed site upstream from Rock Creek (NURCR) in $1995\left(19.5^{\circ} \mathrm{C}\right)$, was roughly equivalent to the highest measured at the same site during 1993 and $1994\left(20^{\circ} \mathrm{C}\right)$. According to the hourly monitor located 0.2 miles downstream (NURCM), warmer water temperatures in 1995 occurred only during the week following the synoptic survey. Slightly warmer temperatures, however, were recorded at the monitor during mid-July in 1994. Although flows tend to be lower during late August and September, data from the monitor have not shown that water temperatures are higher at the lower flows. The highest air temperatures and longest daylight hours are in late June, and stream temperatures were highest in July of both 1994 and 1995 (U.S. Geological Survey, 1995, 1996).

Monitor (NURCM) temperature values have shown good agreement with temperatures measured across the stream cross section at the nearby fixed site (NURCR). Temperatures recorded at the monitor were within $0.5^{\circ} \mathrm{C}$ of temperatures recorded at the same times in cross-sectional measurements at the fixed site in nine of nine cases, including morning and afternoon readings as well as summer and winter readings.

The effect of the hydropower system on water temperatures is difficult to determine. Although the impoundments may provide an opportunity for warming of surficial waters that might otherwise have been protected by relatively narrow, shaded riparian areas, the entrainment of hypolimnetic (bottom) water into the bypass reaches and canals may help to keep summer water temperatures cool. However, just as low flows could contribute to warming in Steamboat Creek, some channel warming could result from the low flows in the bypass reaches. Data collected during this study are insufficient to determine the net effect of the hydroproject on stream temperatures in the Wild and Scenic reach. PacifiCorp (1995a, volume 23) calibrated a temperature model (SNTEMP) for several reaches of the hydroproject area and in the main stem down to Steamboat Creek. The model was used to evaluate the effects of flow changes on stream temperatures, however, and did not specifically address the cumulative effects of the hydroelectric project on temperatures.

Although cumulative temperature changes due to the reservoir system cannot be determined from available data, the magnitude of the daily temperature changes during July 1995 were smallest at sites located immediately downstream from reservoirs (fig. 10). Temperature changes at LEM1T, TOKET, BSODA, and COPEG were $0,1,0.5$, and $1.5^{\circ} \mathrm{C}$, respectively, whereas daily temperature changes at other hydroproject sites were $2-5^{\circ} \mathrm{C}$ or more (PacifiCorp, 1995b). In the case of Lemolo and Toketee Lakes, summer releases are at least partially from thermally stratified hypolimnetic water withdrawal locations, thus maintaining a nearly constant water temperature in the outflow. Although Soda Springs Reservoir appears to only weakly stratify thermally (PacifiCorp, 1995a, volume 22), temperatures at BSODA and COPEG remained fairly constant, possibly because the thermal mass of the reservoir moderates temperature fluctuations. Because releases from Soda Springs dominate flow in the Wild and Scenic reach, the lack of a diel temperature change is translated downstream, resulting in a small daily temperature change at main-stem sites throughout the reach.

Dissolved Oxygen-Contrary to documented conditions in other streams in western Oregon that are affected by periphyton growth (Pogue and Anderson, 1995; Oregon Department of Environmental Quality, 1995; Tanner and Anderson, 1996), DO concentrations in most of the North Umpqua River system appear 

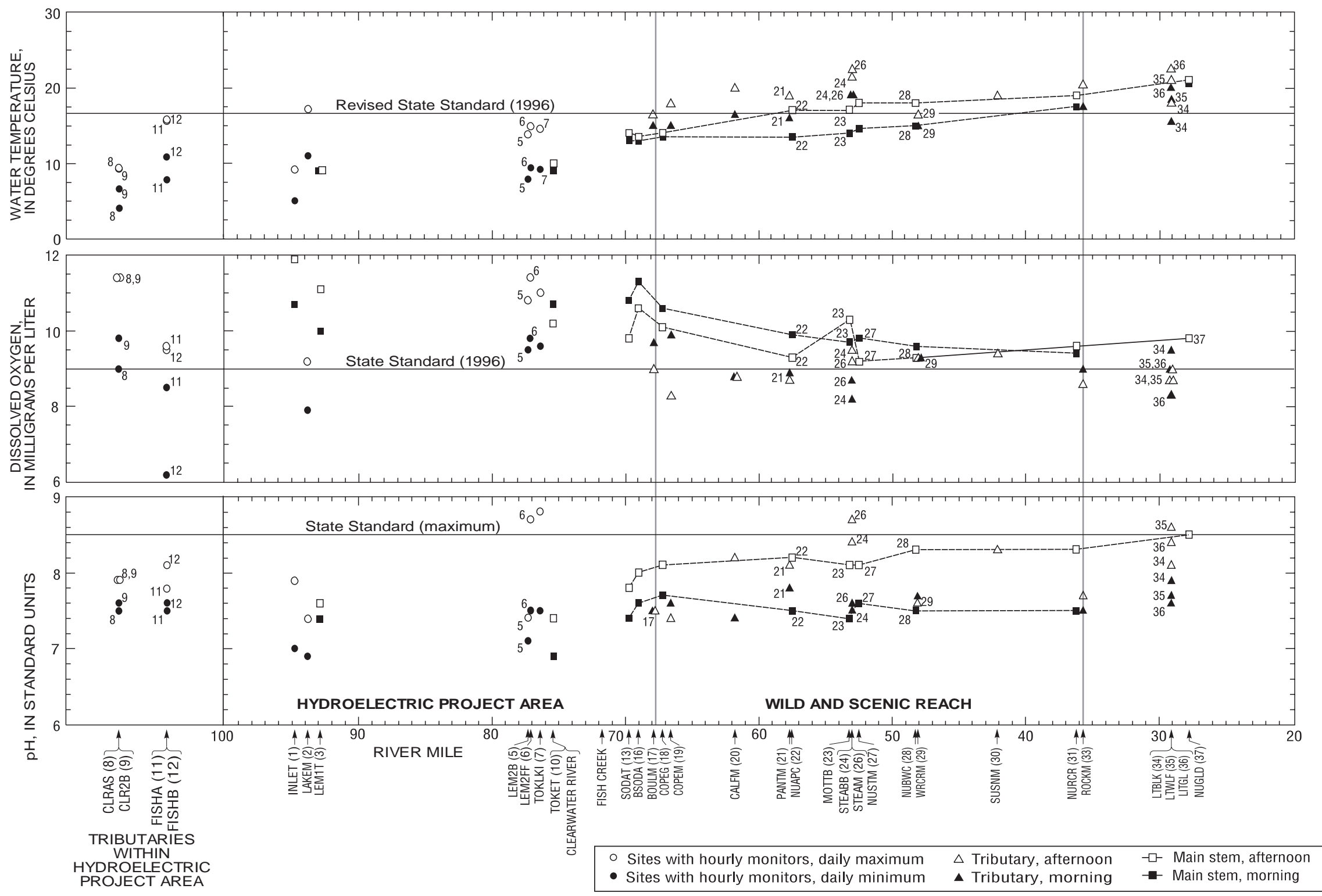

Figure 10. Diel measurements of water temperature, dissolved oxygen, and pH in the North Umpqua River Basin, Oregon, July 1995. (Daily maximum and minimum values for sites measured in the hydroelectric project area by PacifiCorp [circles] were taken from hourly monitors at INLET, LAKEM, LEM2B, LEM2FF, TOKLKI, CLRAS, CLR2B, FISHA, and FISHB. Sites measured by the USGS at main stem [squares] and tributaries [triangles] were visited in morning and afternoon, at times expected to correspond to diel minimum and maximum values. Refer to table 4 for explanation of site names and locations according to acronyms. Source of State standards: Oregon Administrative Rules, Attachment A to Chapter 340, Division 41, 1996.) 
to be controlled primarily by physical factors, such as water temperature and reaeration, rather than by biological metabolism. As a result, daily minimum and maximum DO concentrations measured during 1995 were between 90 and $110 \%$ of saturation in almost all cases (Appendix A). On a milligram per liter basis, maximum DO concentrations often occurred when water temperatures were lowest (in the morning), and minimum DO concentrations occurred when water temperatures were highest (in the afternoon), illustrating the control of DO by temperature. This effect is particularly evident in the upper parts of the Wild and Scenic reach in figure 10, where five of six sites had higher DO concentrations in the morning than in the afternoon. Tributary sites also were near saturation at all times, although the concentrations were somewhat lower due to warmer stream temperatures. Most tributaries along the Wild and Scenic reach had minimum, and commonly maximum, DO concentrations below 9 $\mathrm{mg} / \mathrm{L}$. Sites in the hydroproject area had similar daily patterns.

The lack of low DO concentrations does not imply low primary productivity, but rather that primary production is not as strong as reaeration, deaeration, and water temperature in controlling DO in the North Umpqua River Basin. Indeed, algal growth in the basin is high in some locations, and the steep stream gradient and high water velocities (which result in numerous riffles and rapids, and several water falls) are probably the main reason that DO concentration is maintained at such a high level. Another contributing factor is the force with which water is expelled from the various powerhouses into tailraces within the hydroproject area. This effect is especially significant in ensuring saturated water at BSODA, where a large volume of water enters the river with extreme force and turbulence. The minimum DO concentration observed at BSODA was $10.6 \mathrm{mg} / \mathrm{L}$, which was equivalent to $109 \%$ saturation at the ambient water temperature, and the maximum DO observed was equivalent to $115 \%$ saturation (Appendix A). The initial conditions of DO saturation are thus ensured as water enters the Wild and Scenic reach, where additional turbulence from the steep streambed maintains DO near saturation. One other site that may be similarly influenced by turbulence induced from a powerhouse is LEM2FF, downstream from the Lemolo No. 2 powerhouse (monitored in July 1995 by PacifiCorp). At this full-flow site, algal growth is substantial and primary productivity may contribute to high DO concentrations; however minimum DO concentrations were never lower than $98 \%$ of saturation during the week-long monitoring period, and the maximum was $114 \%$, indicating the influence of turbulence from the powerhouse. Primary production was, however, capable of producing $\mathrm{pH}$ values greater than 8.5 , as will be discussed.

Steamboat Creek above Big Bend Creek (STEABB) was the only site measured by the USGS in 1995 where DO concentration was less than $95 \%$ of saturation, the value of the State of Oregon DO standard in effect during 1995 for salmonid rearing streams. DO at STEABB was $93 \%$ of saturation during a morning measurement. This pattern of low DO concentration in the morning (at low temperature) and high DO concentration in the afternoon (at high temperature) indicates that DO concentration was controlled by primary productivity in Steamboat Creek. Of the sites monitored by PacifiCorp, minimum DO was less than 95\% saturation at LAKEM, and COPEG (PacifiCorp, 1995b).
On the basis of record from the hourly monitor near Rock Creek (NURCM), conditions for DO concentration during the July 1995 synoptic survey approximated a "worst case" during that year. The monitor record indicates that during the week following the synoptic survey the lowest measured DO concentration during 1995 was observed, and that DO concentration during the week of the survey (July 24-29) was almost as low. DO concentration measured from stream cross sections at the fixed site (NURCR) was within $0.7 \mathrm{mg} / \mathrm{L}$ of the value recorded at the nearby monitor for all seven available comparisons between 1993 and 1995. This was the case despite the fact that there are two large riffles (almost waterfalls) in the 0.4 mile distance between the monitor and NURCR.

pH-Unlike DO concentration, $\mathrm{pH}$ appears to respond to primary productivity in spite of the strong reaeration effect of powerhouses and the natural stream gradient. Daily maximum pH was 8.0 downstream from Soda Springs Reservoir (BSODA) and increased downstream (fig. 10). Although none of the main-stem sites in the Wild and Scenic reach exceeded the State standard of $8.5 \mathrm{pH}$ units, $\mathrm{pH}$ was 8.3 at NURCR and 8.5 at NUGLD, and may have reached 8.5 on other days at those sites. As with water temperature, Steamboat Creek and the Little River exhibited high afternoon $\mathrm{pH}$, exceeding 8.5 at STEAM (8.7) and LTWLF (8.6). High values were recorded in these streams previously (Powell, 1997), and pH was 8.4 at other sites within the Steamboat Creek and Little River watersheds during the survey. High $\mathrm{pH}$ (above 8.5) was also observed in the full-flow reach upstream from Toketee Lake at LEM2FF and at TOKLKI, possibly reflecting algal metabolism downstream from LEM2FF (PacifiCorp, 1995b).

The largest diel $\mathrm{pH}$ change, $1.2 \mathrm{pH}$ units, was recorded by PacifiCorp's monitors in the productive tailrace waters of the Lemolo No. 2 powerhouse at LEM2FF. Not far downstream, at the inflow to Toketee Lake (TOKLKI), the diel $\mathrm{pH}$ change was reduced to 0.8 units. In the main stem downstream from Soda Springs Reservoir, the magnitude of diel change in $\mathrm{pH}$ increased in a downstream direction. The change at NUGLD could not be evaluated because there was no morning measurement available at that site.

The algal effects on diel changes in $\mathrm{pH}$ and dissolved oxygen are evident at both sites in Steamboat Creek. Diel $\mathrm{pH}$ values at STEABB and STEAM increased from 7.5 to 8.4 and from 7.5 to 8.7, respectively. Diel DO concentration (as percent saturation) also increased at STEABB and STEAM from $93 \%$ to $116 \%$ and from $97 \%$ to $107 \%$, respectively. The relatively broad diel fluctuations in dissolved oxygen at STEAM actually may be dampened by reaeration processes which occur in the gorge 2.5 miles upstream from STEAM.

Although $\mathrm{pH}$ at the fixed site (NURCR) was 8.3 during the July 1995 synoptic survey, it was 8.5 at that site in 1994 and has been measured in the main stem as high as 8.8 near Wright Creek in 1995 (M.A. Powell, oral commun., 1995). The record from the hourly monitor at NURCM confirms these findings; daily maximum pH was 8.5 in September 1993 and on two days in July and August 1994 (U.S. Geological Survey, 1994 and 1995). The record for $\mathrm{pH}$ at the monitor agrees well with data from crosssectional measurements made at NURCR. In all nine visits to NURCR between 1993 and 1995, during high and low flows and 
for morning and afternoon measurements, $\mathrm{pH}$ measured in the cross section was within $0.2 \mathrm{pH}$ units of the value recorded at the monitor for the same time. For 1995, the monitor record indicates that conditions during the week of the survey represent worst case conditions (highest maximum $\mathrm{pH}$ ) for 1995.

Although DO concentration was generally controlled by reaeration and stream temperature, $\mathrm{pH}$ responded to primary production. The moderately to poorly buffered North Umpqua River (median alkalinity was $28 \mathrm{mg} / \mathrm{L}$ as $\mathrm{CaCO}_{3}$ in 1995) is apparently very sensitive to small changes in the concentration of inorganic carbon. Owing to the fact that $\mathrm{pH}$ in natural waters is controlled primarily by the equilibrium of the carbonic acid cycle (Stumm and Morgan, 1981) (eq. 2, p. 12), reaeration with gaseous $\mathrm{CO}_{2}$ below powerhouses probably contributes to an effective lowering of the $\mathrm{pH}$ at those sites. Evidence of this phenomenon has been observed in the Wild and Scenic reach: records from temporary monitors at BSODA and COPEG in August 1995 (PacifiCorp, 1995, unpublished data) indicate a somewhat depressed minimum $\mathrm{pH}$ at BSODA (approximately 7.0 at midnight) but a consistent increase of $0.4-0.6 \mathrm{pH}$ units by COPEG just 1.8 miles (approximately 2 hours travel time) downstream. Maximum $\mathrm{pH}$ occurred around 4:00 p.m. at BSODA (7.4 units) and COPEG (8.0 units). Given that there is abundant, although patchy, active algal growth immediately downstream from BSODA, this increase could partially be due to algal photosynthesis; however, degassing of excess $\mathrm{CO}_{2}$ from powerhouse releases at BSODA could also account for part of this shift. The productive full-flow reach downstream from the Lemolo No. 2 powerhouse produced high $\mathrm{pH}$ at LEM2FF (8.7 pH units), despite the apparent tendency of the powerhouses to reaerate and even supersaturate the waters in the tailraces with atmospheric gases. Consequently, $\mathrm{pH}$ could be even higher at LEM2FF without the effect of reaeration from the Lemolo No. 2 powerhouse.

\section{RELATIONS OF WATER QUALITY AND ALGAL CONDITIONS TO RESOURCE MANAGEMENT}

The principal resource-management activities in the North Umpqua River Basin are forestry and hydropower production. Both of these activities have caused the landscape to be changed in dramatic and significant ways. This study was intended as a reconnaissance-level investigation and, as such, did not completely address either of these activities. The results, however, offer insights into water-quality processes in the North Umpqua River on which to base future studies. In the following sections, an initial, conceptual model of the physical and ecological processes in streams of the North Umpqua River Basin is developed on the basis of results from the current study, integrated with recent and historical information in the North Umpqua River Basin and relevant findings from the literature. Potential future studies are suggested that would either test and refine parts of this model or provide information to fill key data gaps.

\section{Forestry}

Management of forests for timber in the Pacific Northwest has become a highly visible and contentious issue. Timber pro- duction is an important component of the economy of Douglas County and has occurred extensively within the North Umpqua River Basin. Much of the industrial timber harvests in the basin have occurred on private timber lands, although there also has been significant harvest on public lands in the Glide and Diamond Lake Ranger Districts of the Umpqua National Forest. Of the $1,209 \mathrm{mi}^{2}$ total area, an estimated $94 \%$ is commercial forest. The estimated portion of land designated as commercial forest in individual watersheds ranges from 88 to $97 \%$. Most of the land upstream of Soda Springs either remains uncut or was harvested more than 80 years ago. In contrast, the watersheds downstream of the hydroproject area, including the Wild and Scenic reach, have had between 34 and $41 \%$ of the forest areas harvested in the last 40 years. Although most of the land in the North Umpqua watershed is owned by the U.S. Forest Service, private timber companies own approximately $12-35 \%$ of the lands in the Little River, Steamboat Creek, and Middle North Umpqua (along the Wild and Scenic reach) Basins (Mikeal Jones, U.S. Forest Service, written commun., 1997). In the Steamboat Creek Basin, harvesting has occurred in every subbasin (Holaday, 1992).

Potential effects of timber management on water quality are numerous and have been extensively reviewed (Meehan, 1991). Included are the potential effects of silviculture and timber harvest on (1) nutrient loss from soils to receiving waters, especially in areas that have been clear cut (Fredrikson, 1971; Adams and Stack, 1989; Greene, 1996), (2) erosion and sediment transport to streams (Chamberlain and others, 1991), (3) morphological changes, such as stream-channel widening (Dose and Roper, 1994) and reductions in channel complexity (Fausch and Northcote, 1992), through changes in the amount of large woody debris (LWD) in streams, (4) increases in diel pH changes and maximum pH (Powell, 1997), (5) temperature changes, especially during summer low-flow conditions (Murphy and Meehan, 1991; Holaday, 1992), (6) chemical inputs from the use of fertilizers, pesticides, and fire retardants (Norris and others, 1991). Some of these may be important in the North Umpqua River Basin, either alone or in combination with other land management practices, and are briefly explored in this section.

Effects of forestry on streamflow have been documented extensively for other forests (Chamberlin and others, 1991; Nakama and Risley, 1993; Jones and Grant, 1996), and some forestry activities could have affected streamflow in the North Umpqua River Basin. The available hydrologic data and information on historical land use in basin may be sufficient to allow such an analysis to be performed; however, the analysis is beyond the scope of this report.

Few data are available for direct assessment of nutrient loss from soils in the North Umpqua River Basin. Forestry-related events that would contribute to nutrient export include erosion from clearcutting, roadbuilding, landslides, and fertilization. Entry routes may be either through tributaries, direct runoff, or ground-water inputs (Triska and others, 1983; Triska, Kennedy, and others, 1989). Nitrogen was rarely detected in the main stem and tributaries, in spite of the sometimes abundant algal growth; however, inputs of nutrients, especially nitrogen, are more likely to be incorporated into algal biomass immediately upon entry into the stream rather than to remain in the water column. Such 
inputs therefore could be particularly difficult to distinguish by traditional water-column measurements alone.

In the Little River watershed, patterns of sediment loss and erosion resulting from forest-management practices are considered by the U.S. Forest Service to have resulted in an aquatic habitat that is highly disturbed and less diverse than it was historically (U.S. Forest Service and Bureau of Land Management, 1995). In several subbasins, landslide frequency has increased and streambank stability has decreased, resulting in increased sediment delivery to the Little River. Many of these subbasins, including two sampled in the July 1995 survey, are also locations where maximum $\mathrm{pH}$ of streamflow was elevated, in some cases to levels higher than the State standard of 8.5 (Powell, 1995); this increase in $\mathrm{pH}$ has been attributed to the extensive amount of logging (U.S. Forest Service and Bureau of Land Management, 1995; Powell, 1997) in the basin.

The Steamboat Creek Basin appears to have been similarly affected by its history of logging. With a wide bedrock channel and little riparian canopy $(73 \%$ and $88 \%$ open at STEABB and STEAM, respectively), Steamboat Creek had water temperatures and $\mathrm{pH}$ levels that were among the highest observed in this study, and a relatively high abundance of eutrophic algal taxa (especially at the upstream site, STEABB). The relative impact of forestry along other sections of the main stem or the smaller tributaries to the Wild and Scenic reach were not evaluated in this report because of a lack of data and the possible confounding effects of hydropower operations.

The presence of LWD can dissipate stream energy (Heede, 1972; Marston, 1982), promote complex channel morphologies (Fausch and Northcote, 1992), foster depositional processes, and provide valuable refuge for fishes (Murphy and Meehan, 1991). Stream surveys conducted by PacifiCorp (1995a, volume 4), however, indicated that LWD were scarce (approximately five logs per mile) in the North Umpqua River downstream of Soda Springs Reservoir. The reasons for the lack of LWD are unclear. Although PacifiCorp attributed the lack of LWD primarily to removal of riparian vegetation by highway construction and forestry rather than interception by reservoirs; the reservoirs would be likely to interrupt the downstream transport of any large logs that fall into the stream channels within the hydroproject area. Removal of large trees in riparian areas along Highway 138 also could contribute to the lack of LWD in the river. The lack of LWD also could be a factor in the relatively large amount of exposed bedrock (and lack of gravel) downstream of Soda Springs Reservoir: Dose and Roper (1994) determined that the removal of LWD and the presence of valley-floor roads were partially responsible for a widening of stream channels and removal of stream gravel to bedrock in forested watersheds in the South Umpqua River Basin.

As part of the traditional management of forest land, fertilizers are applied to enhance tree growth and speed forest recovery after harvesting. Fertilizers also are used to promote growth of vegetation for erosion control, particularly alongside roads immediately after construction, and during watershed restoration processes at bridges and on unstable slopes. The primary forest fertilizer is nitrogen (applied as urea) because forest soils are often poor in nitrogen, particularly in the Western Cascades (Norris and others, 1991). In treated and untreated watersheds in the nearby South Umpqua Experimental Forest (Moore, 1971), approximately $0.01 \%$ of applied fertilizer reached the streams during the summer low-flow period; peak nitrogen concentrations were observed during high flows in December. In the same study, nitrogen loss to streams from treated watersheds, over $95 \%$ of which was ammonium-nitrogen transformed through nitrification to nitrate-nitrogen, was more than an order of magnitude greater than from untreated watersheds. Not surprisingly, larger amounts of nitrogen loss have been reported when some of the fertilizer was applied directly to water during the forest fertilization process (Norris and others, 1991). Long-term records of fertilizer use in the North Umpqua River Basin were not available; however, estimates of fertilizer use from 1993-95 are presented in table 11 .

Fertilizer use in the North Umpqua River Basin was curtailed after 1993 because of emerging concerns regarding nutrient inputs to the river and their potential impacts on algal growth and pH (Mikeal Jones, U.S. Forest Service, written commun., 1995). Some applications, however, were performed in 1994 and 1995. In 1995, for example, forests were fertilized by hand in areas outside of riparian reserves. The estimates given in table 11, therefore, are possibly less than historical fertilizer applications, although the 465,000 pounds of nitrogen applied (as urea) in 1993 in the North Umpqua Ranger District is apparently indica-

Table 11. Estimated nitrogen in fertilizer used in the North Umpqua River Basin, Oregon, 1993-95

[Units are in pounds of nitrogen. The boundary between the North Umpqua and Diamond Lake Ranger Districts of the Umpqua National Forest is at Calf Creek. RD., ranger district. Source: Mikeal Jones, U.S. Forest Service, written commun., 1995]

\begin{tabular}{|c|c|c|c|c|c|c|}
\hline \multirow[b]{3}{*}{ Practice } & \multicolumn{6}{|c|}{ Estimated nitrogen, in pounds } \\
\hline & \multicolumn{2}{|c|}{1993} & \multicolumn{2}{|c|}{1994} & \multicolumn{2}{|c|}{-995} \\
\hline & $\begin{array}{l}\text { Diamond } \\
\text { Lake } \\
\text { RD }\end{array}$ & $\begin{array}{c}\text { North } \\
\text { Umpqua } \\
\text { RD }\end{array}$ & $\begin{array}{l}\text { Diamond } \\
\text { Lake } \\
\text { RD }\end{array}$ & $\begin{array}{c}\text { North } \\
\text { Umpqua } \\
\text { RD }\end{array}$ & $\begin{array}{c}\text { Diamond } \\
\text { Lake } \\
\text { RD }\end{array}$ & $\begin{array}{c}\text { North> } \\
\text { Umpqua } \\
\text { RD }\end{array}$ \\
\hline Highway reconstruction & 0 & 0 & 0 & 288 & 0 & 0 \\
\hline $\begin{array}{l}\text { Forest fertilization } \\
\text { (1993 helicopter, } 1995 \text { hand) }\end{array}$ & 0 & 465,000 & 0 & 0 & 2,788 & trace \\
\hline Timber sale road construction & 0 & unknown & 80 & 0 & 640 & 0 \\
\hline Watershed restoration & 500 & 0 & 0 & 125 & 0 & 48 \\
\hline Total & 500 & 465,000 & 80 & 413 & 3,428 & 48 \\
\hline
\end{tabular}


tive of historical patterns. Phosphorus was applied in the North Umpqua River Basin only for erosion control along roadways or for watershed restoration, in amounts similar to nitrogen applications for those uses. The Steamboat Creek, Little River, and Middle North Umpqua River Basins, which have been the most intensively logged, were also the most intensively fertilized historically (Mikeal Jones, U.S. Forest Service, written commun., 1995).

Firefighting, and the chemicals and soil disturbances accompanying it, also are potential sources of nutrients to forest streams. Fire retardants are largely composed of nitrogen and phosphorus (commonly as $\left(\mathrm{NH}_{4}\right)_{2} \mathrm{HPO}_{4}$, diammonium phosphate), in very high concentrations. In a small experiment, Norris and others (1991) reported that ammonium and total phosphorus reached a stream within 24 hours after application of retardants, and that the ammonium was subsequently transformed into $\mathrm{NO}_{3}{ }^{-}$ and dissolved organic nitrogen (TDN). The compounds were detected more than 3,000 feet downstream; however, only minor amounts of chemicals were exported from the riparian areas (approximately 10 feet on each side) in which they were applied. Although these effects may be minor under most conditions, inputs from a single protracted fire or an accidental spill of retardant are potentially important.

Thus, indirect effects of forestry on algal growth may include increased light availability from reduced riparian coverage; changes in substrate type or stability resulting from changes in sediment delivery and flow rates or loss of LWD; changes in scour (from sediment delivery or stream velocity) resulting from changes in the flow regime, and changes in nutrient delivery. Although there are few data to directly evaluate these effects along the main-stem North Umpqua River, there are indications of some of these effects in tributaries such as Steamboat Creek and Little River, where logging has been prevalent and there are no impoundments. In these streams, water temperatures are elevated, algal growth is high, and the algal community composition (nitrogen heterotrophs, and eutrophic and alkaliphilic taxa) indicate a general degradation of water quality.

\section{Hydropower}

In the North Umpqua River system, the reservoirs within the hydroproject area have been studied relative to their effects on streamflow in the downstream reaches. The reservoirs and impoundments were routinely monitored in connection with relicensing studies conducted from 1992 through 1994 (PacifiCorp 1995a). The focus of these studies was on characterizing existing conditions and on compliance with State of Oregon water-quality standards. Reservoir surface waters were extensively sampled, but bottom waters, from which most of the releases to the bypass reaches and power canals are drawn, were seldom sampled, and data on organic nitrogen and dissolved $\mathrm{NH}_{4}{ }^{+}$concentrations are scarce. With the exception of some of the ongoing work associated with a watershed analysis along the Wild and Scenic reach upstream of Rock Creek (PacifiCorp, 1997), few data have been collected to specifically evaluate the processing of sediments or nutrients as they move from the inflows to the reservoirs, their fate in the reservoirs, and their subsequent release into down- stream reaches. Furthermore, the effects of water diversion for power generation and the effects of the associated low flows on primary production in the previous natural stream channels have been only nominally addressed. Finally, the cumulative effects of the reservoir system on water quality in the Wild and Scenic reach downstream are largely unknown. This study, although limited in duration, was the first attempt to examine nutrients and the algal community within and below the hydropower project area in the context of overall ecosystem functioning.

\section{Effects of Reservoirs on Water Quality}

Studies have indicated that major reservoirs can affect, directly or indirectly, many ecological aspects of the lotic (flowing water) ecosystem downstream (Ward and Stanford, 1983a; Ligon and others, 1995). In some cases investigators have observed such effects as increased transport of ammonium nitrogen and resulting increases in chlorophyll $a$ and $\mathrm{pH}$ immediately below reservoirs (Marcus, 1980; Dufford and others, 1987). Other downstream effects of dams on benthic communities can come from hydrologic effects of flow regulation on sediment transport and food-web processing. Transport of fluvial and organic material often depends, in part, on processes upstream (Vannote and others, 1983; Murphy and Meehan, 1991); interruptions of these processes can deprive downstream reaches of important components in the structure of their ecosystems, on which salmonids and other aquatic biota depend (Sullivan and others, 1987). Interception of sediments from upstream areas is one of the principal effects of dams (Collier and others, 1996), and water released from reservoirs therefore tends to be clearer and more able to resuspend small particles from streambeds downstream, thus coarsening the streambed. The lack of gravel in the reach downstream from Soda Springs Dam could be due to interception of sediment by the upstream reservoir system, or to coarsening of the streambed by the clearer water, or a combination of both processes. Algal abundances can be affected by scour, either positively (Power, 1992a) or negatively (Horner and others, 1983; Biggs, 1996). Changes in the frequency of scour and flooding below reservoirs can also affect the abundances of invertebrates (Wooten and others, 1996), which can in turn affect other trophic levels both above and below invertebrates in aquatic food webs.

The deposition of suspended sediment and coarse organic matter, from the water column and to the bottom sediments of a reservoir, also can degrade the water quality of the reservoir itself (Chapra, 1981). Along with sediment and gravel, reservoirs intercept other transported debris, including organic matter such as LWD and leaf litter. These materials can remain in the reservoirs for much longer than the hydraulic residence time of the water body, such that the rate of accumulation of organic materials can be rapid (Thornton, 1990a). Coarse-grained organic particulate matter (CPOM) tends to settle in the upper reaches of reservoirs, whereas finer-grained organic matter (FPOM) may be transported further longitudinally (Thornton, 1990b, Kennedy and Walker, 1990). Planktonic algae process nutrients in reservoirs, adding nutrients to bottom sediment as detrital material when the algae become senescent, and thereby convert incoming inorganic nutrients into organic matter. Microbial activity in bottom sediments 
can convert labile and moderately labile inorganic and organic compounds into dissolved forms that can be readily entrained into the water column near the sediment-water interface. Ward and Stanford (1983a), in discussing the ecology of rivers with headwater impoundments, postulated sharp decreases in the ratio of coarse-grained to fine-grained particulate organic matter (CPOM:FPOM) downstream of dams. Such changes, which could occur either because the downstream transport of CPOM is interrupted or the transport of FPOM and dissolved organic matter (DOM) is increased, are expected to significantly alter the functional feeding groups of downstream invertebrate communities. Additional effects were anticipated from disruption of the natural thermal regime, including decreases in biological diversity and changes in timing of invertebrate hatches associated with the more stable temperature of reservoir outflows (Ward and Stanford, 1983b).

Allochthonous (originating outside the stream) organic material can be the primary energy source for ecosystems in lotic environments (Vannote and others, 1980; Allen, 1995). Organic detritus (especially leaf litter) and LWD provide important food and habitat resources for groups of macroinvertebrates (detritivores and shredders) that could in turn be important food sources for salmonid fishes. Salmonids can subsist on prey attached to the benthos, however they eat predominantly drifting terrestrial and aquatic prey, such as those associated with LWD and other allochthonous organic material (Murphy and Meehan, 1991). Fausch and Northcote (1992) found that biomass of age-group one and older salmonids was significantly greater in stream segments with greater amounts of LWD and significant riparian vegetation. The contribution of LWD to improved stream habitat extends downstream as well, as particulate organic matter is transported from one stream reach to downstream reaches. To the extent that LWD occurrence in the North Umpqua River can be controlled by resource managers, either by allowing it to remain in the river when natural events introduce it to the system, or by assisting its transport through the reservoir system instead of removing it, LWD represents a variable that can be used to help the river develop greater ecosystem complexity.

Although not expressly investigated in this study, the conversion of incoming inorganic and large organic debris into smaller particulate or dissolved organic matter, as described above, could be occurring in reservoirs in the North Umpqua River Basin. Likely locations for such processes include Lemolo Lake, Toketee Lake, and Soda Springs Reservoir. Relatively high concentrations of TKN and elevated biomass of periphyton below these impoundments, including species that are adapted to utilize organic forms of nutrients (fig. 7, table 10) are indications that these changes could have taken place to varying degrees. Such changes in the CPOM:FPOM ratio could imply fundamental shifts in the ecological structure of the benthic community below the reservoirs and for some distance downstream.

Water quality - Water released from the hydroproject area at Soda Springs Reservoir clearly dominates the water quantity and quality in the Wild and Scenic reach during the summer. Tributary inputs and accretion constitute a relatively minor input but may be locally important. As a result of the constant expulsion of water from the Soda Springs powerhouse, water entering the Wild and Scenic reach has minimal diel temperature variation (less than $1.0^{\circ} \mathrm{C}$ ), and DO is at or above saturation at all times (fig. 10). This effect is translated downstream, as diel temperature changes remain small throughout the main stem (to Rock Creek) and physical reaeration maintains DO near saturation. The depressed $\mathrm{pH}$ immediately downstream from Soda Springs (maximum $\mathrm{pH}$ 8.0), despite patchy but prolific algal growth at that site, probably is a combined result of the low $\mathrm{pH}$ in water from Soda Springs Reservoir and the powerful forces of reaeration from the powerhouse, which may supersaturate the water with respect to $\mathrm{CO}_{2}$ and further lower $\mathrm{pH}$. The direct effect of reservoir releases on $\mathrm{pH}$ farther downstream appears less marked as dissolved $\mathrm{CO}_{2}$ degasses from the river and the productivity of algae, in the relatively low alkalinity waters of the North Umpqua River, is strong enough to raise $\mathrm{pH}$ downstream despite continuing physical reaeration. Reservoir releases can potentially affect $\mathrm{pH}$ indirectly as nutrients are made available for increased algal metabolism in downstream areas.

Results from this study indicate that water released from Soda Springs Reservoir also is the primary nutrient source to the Wild and Scenic reach. Phosphorus concentrations, of which $80 \%$ of the TP was as SRP, decline moderately (by about 10 $\mu \mathrm{g} / \mathrm{L})$ from just below the reservoir to Glide. As a result of the extremely low concentrations of inorganic nitrogen, which is likely the limiting nutrient throughout most of the basin, any additional nitrogen inputs to the river are masked by rapid benthic recycling and uptake, and utilization of alternative nutrient forms (such as dissolved organic nitrogen). Algal abundances and analysis of community composition also indicate that each of the reservoirs contributes nutrients that are immediately consumed by algae in the reaches downstream from the impoundments. Water withdrawn from each of the reservoirs, except Stump Lake, includes bottom water. Nutrients are either released directly, in the water from the reservoirs, or could be transported in water leaking underneath dams and added to water in the bypass reaches by accretion. Elevated concentrations of $\mathrm{NO}_{3}{ }^{-}$ (230-910 $\mu \mathrm{g} / \mathrm{L})$ were observed during 1993 in the Slide Creek, Fish Creek, and Clearwater bypass reaches (PacifiCorp, 1995a, volume 22), although these data appear to be outliers.

With the exception of a TKN concentration that was estimated to be about $100 \mu \mathrm{g} / \mathrm{L}$, nitrogen was not detectable in water released from Soda Springs Reservoir during the 1995 synoptic survey. Reservoir releases, however, were held artificially stable for purposes of constructing mass balances for flow and nutrient loads, a factor that could have indirectly exacerbated nutrient limitation and caused increased algal nutrient uptake in the Wild and Scenic reach. Under normal operating conditions, when flows through the entire reservoir system are more dynamic, fluctuations in nutrient concentrations could result in higher average concentrations being discharged to the Wild and Scenic reach. This possibility is supported by the higher concentration of $\mathrm{NH}_{4}^{+}$ observed at the Copeland Creek gage (COPEG) at the end of the survey in 1995, and by the slightly higher nitrogen and phosphorus concentrations observed at the fixed site (NURCR) during 1993 and 1994, although factors such as fertilization or other human activities also could have contributed to these higher concentrations.

Organic enrichment-Several factors support the hypothesis that the reservoirs are effectively transforming incoming 
nutrients into dissolved organic and ammonium forms from inorganic and detrital forms, as postulated for impoundments in headwater streams by Ward and Stanford (1983a). Phytoplankton algal blooms have been noted in Lemolo Lake, Toketee, and Soda Springs reservoirs. The processes of ammonification and remineralization of organic materials (including dying algal cells as well as incoming detritus) often occurs in the sediments of reservoirs and is a likely source of nutrients downstream. Dufford and others (1987) found increased algal biomass downstream from reservoirs in Colorado having bottom releases, but found no differences below surface-withdrawal reservoirs. Releases from Toketee Lake and Soda Springs Reservoir are integrated and therefore include bottom water, as does the release from Lemolo Lake (table 1). Elevated concentrations of TKN have been observed downstream from Stump Lake, and at depth in Lemolo and Toketee Lakes (PacifiCorp, 1995a, volume 22), and qualitatively estimated concentrations of TKN were higher downstream from the reservoirs compared with concentrations at other site types in July 1995. The abundance of nitrogen heterotrophic taxa was greater at hydroproject sites compared with main-stem sites, indicating that there are sources of organic nitrogen in the hydroproject area. One tributary site in 1995 (STEABB), and the fixed site upstream of Rock Creek (NURCR) in 1994, also had a relatively high abundance of nitrogen heterotrophs.

Given the low inorganic nitrogen concentrations observed and the presence of a facultative nitrogen heterotrophic taxon, the utilization of organic nitrogen compounds may have fueled the prolific growths of periphyton observed in this study. Melosira varians, a nitrogen heterotrophic taxon, made up $29 \%$ of the biovolume at TOKET, which is in the range (20\%-40\% abundance) suggested by Reimer (1962) to indicate organic enrichment. The abundance of nitrogen heterotrophic taxa was greater at the hydroproject sites than at main-stem or tributary sites. These observations indicate a source of organic nitrogen in the hydroproject area and in Steamboat Creek. The physiological health of the periphyton community itself may also contribute to the presence of nitrogen heterotrophic taxa at these sites. Dissolved organic nitrogen probably is released upon the decay of the algal community, and would likely be exacerbated by high algal biomass (project sites and INLET) or high water temperatures (STEABB).

\section{Effects of Reservoirs on Algal Abundance and Distribution}

The most distinct observation concerning algal abundance in this study was that algal biomass was more than 2 to 3 times greater at sites downstream from impoundments, either below dams (LEM1T and TOKET) or powerhouses (BSODA and other sites observed in 1996). PacifiCorp previously reported dense growths of filamentous algae (probably Cladophora) in the tailraces downstream from Lemolo No. 1 and No. 2 powerhouses, Clearwater No. 1 and No. 2 powerhouses, in the full-flow reach $200 \mathrm{~m}$ downstream from Lemolo No. 1 powerhouses (LEM2FF), and downstream from Toketee Dam (TOKET) (PacifiCorp, 1995b). The pronounced diel swings in $\mathrm{pH}$ (7.5-8.7) at LEM2FF were attributed to periphyton metabolism by PacifiCorp (1995b).

Three hydroproject sites (BSODA, LEM1T, and TOKET) and INLET had the highest concentrations of dissolved phospho- rus. Spearman rank correlations between periphytic chlorophyll $a$ and phosphorus at the 10 sites sampled in 1995 were significant $\left(\mathrm{R}^{2}=0.65, \mathrm{p}<0.05\right)$. On the basis of the apparent relation between chlorophyll $a$ and phosphorus, periphyton growth could be interpreted as being phosphorus limited; however, this could be misleading because inorganic nitrogen concentrations were at or below the MRL at all sites, whereas phosphorus concentrations appeared plentiful (fig. 5). On the other hand, the capacity for nitrogen fixation can compensate for low nitrogen concentrations, which would effectively render streams phosphorus limited (Elwood and others, 1981).

The thick periphyton mats observed in this study apparently undergo periodic sloughing, particularly in the hydroproject area (Dave Schwall, PacifiCorp, oral commun., 1996), suggesting that the basal cells are nutrient limited at those times (Biggs, 1996). Basal cells inside the periphyton mat rely on diffusion-limited nutrient transport and (or) recycling of nutrients and most likely are exposed to lower nutrient concentrations than surficial cells. Bothwell (1988) demonstrated that phosphorus concentrations higher than $0.3-0.6 \mu \mathrm{g} / \mathrm{L}$ had no effect on growth rates in diatom communities from the South Thompson River, British Columbia. Other studies have shown, however, that phosphorus additions of up to 30 to $50 \mu \mathrm{g} / \mathrm{L}$, concentrations similar to those observed in the North Umpqua River Basin, can continue to increase algal biomass (Horner and others, 1983; Bothwell, 1988).

At first glance, the algal taxa identified from the North Umpqua River resemble those in unregulated pristine mountainous streams (Dufford and others, 1987). Many of the sites have a high abundance of blue-green and diatom nitrogen-fixing taxa typical of streams with low concentrations of nitrogen (Petersen and Grimm, 1992). Closer examination, however, reveals the presence of algal taxa that are indicative of nutrient enrichment and alkaline $\mathrm{pH}$, and a scarcity of taxa that are indicative of oligotrophic and cold-water conditions. Furthermore, concentrations of chlorophyll $a$ and AFDM in the North Umpqua River are indicative of moderately enriched to enriched streams, as described by Biggs (1996).

Eutrophic algae were observed at every site sampled, although their abundances were most pronounced at hydroproject sites. An exception to this was the uppermost site in Steamboat Creek (STEABB), where eutrophic taxa made up $62 \%$ of the biovolume, and in samples from July and September 1994 at the fixed site (NURCR), where they comprised $42 \%$ and $51 \%$ of the respective algal biovolumes. In the bypass reaches below dams (TOKET and LEM1T), eutrophic taxa comprised 67\% and 74\%, respectively, which is consistent with findings from Dufford and others (1987), who found that the flora downstream from bottom-release impoundments in Colorado were dominated by algal taxa indicative of eutrophic conditions, whereas the flora upstream from reservoirs were primarily indicators of oligotrophic conditions. The algal communities upstream and downstream from surface-release impoundments in that study were nearly identical. In the North Umpqua River Basin, sites immediately downstream from impoundments also tended to have the highest concentrations of organic nitrogen.

Blue-green algae, most of which are nitrogen fixers, dominated the periphyton communities in the Wild and Scenic reach and in Steamboat Creek, but were relatively rare at the hydro- 
project sites. Blue-green nitrogen fixers tend to dominate periphyton communities when concentrations of nitrogen are low and concentrations of phosphorus are high, when water temperatures are high $\left(20^{\circ} \mathrm{C}\right.$ or more) (Tilman and others, 1986), or at high $\mathrm{pH}$ values (Shapiro, 1990). BSODA had an abundance of the diatom nitrogen fixers, but these forms are less efficient at fixing nitrogen than the heterocystous, blue-green forms (Floener and Bothe, 1980), and a shift from diatom nitrogen fixers toward blue-green nitrogen fixers is expected as nitrogen concentrations decrease, temperatures increase, or when grazing pressure increases (Petersen and Grimm, 1992; Walton and others, 1995). This pattern was evident in Steamboat Creek, where the diatom nitrogen-fixers Epithemia sp. and Rhopalodia gibba dominated the periphyton community at the upper site (STEABB) and blue-green species became dominant at the downstream site (STEAM). Stream temperatures at STEAM $\left(22.5^{\circ} \mathrm{C}\right)$ were only slightly higher than at STEABB $\left(21.5^{\circ} \mathrm{C}\right)$, suggesting that nitrogen concentrations or grazing pressure, rather than temperatures, could be responsible for the differences in periphyton communities at these sites. An unidentified gastropod grazer was particularly abundant at STEAM, while none was observed at STEABB. Water temperatures were relatively cool at hydroproject sites, which could help explain the much reduced abundance of blue-green nitrogen fixers at these sites compared with main-stem and tributary sites.

Filamentous green algae were observed primarily at sites in the hydroproject areas, but also were observed at NURCR.

Although the mere presence of these algal forms cannot be used to identify nutrient enrichment, their high abundance (up to 440 $\mathrm{mg} / \mathrm{m}^{2}$ ) strongly suggests that sites downstream from dams and powerhouses are providing relatively high concentrations of dissolved nutrients (Biggs, 1996; Borchardt, 1996). Cladophora has also been shown to occur in nitrogen-poor habitats, presumably because Cladophora often hosts nitrogen-fixing epithemiacean diatom that grow as epiphytes, which may provide a source of nitrogen (Dodds and Gudder, 1992). Fitzgerald (1969) found that non-nitrogen fixing epiphytes colonized Cladophora only when surplus nitrogen was available. Filamentous green algae from samples collected from BSODA in 1995, and from samples collected from Lemolo No. 1 and No. 2 and Clearwater No. 2 powerhouse in 1996, contained a high proportion of non-nitrogen fixing diatom epiphytes, indicating a possible surplus of nitrogen at these sites.

\section{Suggestions for Future Studies}

There are several topics for which additional study would provide a better understanding of the North Umpqua River system, facilitate management of water quality, and provide a benchmark for measuring the effects of changes in forestry practices or in reservoir-management activities. These topics are explored in the following sections: Background Conditions, Nutrient Status and Limitation, Geomorphology, Reservoir Processing, Primary Production and Algal Distribution, and Food Web Dynamics. The topics are not mutually exclusive; in fact, there may be considerable overlap. The suggestions are presented herein only in generalized terms to provide a basis for consideration of future studies; discussions among water managers, natural resource agencies, scientific researchers, and the public will be necessary to refine and prioritize these ideas, decide on specific objectives, and choose the most appropriate courses of action.

\section{Background Conditions}

Much of the uncertainty over the effects of forestry and hydropower operations on water quality in the North Umpqua River Basin originates with questions of the natural conditions of the river basin. The natural temperature and $\mathrm{pH}$ of tributaries, such as Steamboat Creek, the nutrient regime in the main stem and bypass reaches, and the amount of algal growth expected in these streams are basic questions that cannot currently be answered. Several avenues exist to begin to answer these questions, including studies of ground water, paleolimnology, the status of forest soils and their nutrient retention during disturbance, and hyporheic flow and processing of nutrients. Also, a study to confirm the presence of arsenic and determine its sources might be warranted from results presented in this report.

Ground Water-A ground-water study could be used to investigate potential inputs in key locations, notably within the hydroproject area (especially the Clearwater River Basin) and the inflows to Lemolo Lake at INLET and LAKEM. The rich algal growth and relatively high nutrient concentrations at INLET in particular are unexplained, but may result from unique flow patterns in the porous pumice soils of the Western Cascades, possibly linking water from Lake Creek to the upper North Umpqua River upstream from Lemolo Lake. An additional aspect that remains unclear is the potential input of sewage residues from septic systems into Toketee Lake at Clearwater Village and from other camping and recreation facilities, such as those at Lemolo Lake. Ground water in the Clearwater River Basin appears to contribute a large volume of water and potentially high nutrient concentrations (PacifiCorp, 1995b), and quantification of these inputs would help to understand nutrient sources in the basin. Input of nutrients from ground water along the main stem in the Wild and Scenic reach appears to be negligible on the basis of flow, chloride, and phosphorus mass balances. This finding could possibly be verified by sampling select wells along the reach and expressly investigating ground-water input to the river. Finally, ground-water samples could be analyzed for arsenic to help determine arsenic sources in the basin.

Sediment Record-One way to determine the composition of past algal communities in both the natural stream channels and the reservoirs, and to determine if water quality in these areas is changing over time, would be to investigate the record of chemistry and algal growth contained in sediment deposits within the lakes and forebays of the basin. Algal cells, particularly the silicious diatom frustules, are often preserved in sediments. Identification of these cells and the use of autecological classifications and multivariate techniques, such as those employed in this study, can provide an indication of long-term environmental conditions or other changes (Dixit and others, 1992; Christie and Smol, 1996). In the North Umpqua River, such a study could help determine historical patterns of water chemistry, such as the natural $\mathrm{pH}$ and temperature ranges of the main stem and tributary waters, the relative amounts of nitrogen and phosphorus inputs 
and nutrient limitation status, and rates of primary production. Chemical analysis of sediment samples from streambeds and impoundments could provide additional information, such as sediment age, sedimentation rates, states of organic and inorganic enrichment, and other potential effects of land use. Identification of suitable sites for sediment sampling and an understanding of the limitations of differentiating sediment deposits in lotic (flowing) as opposed to lentic (impounded) environments would of course be critical to the success of such an investigation.

\section{Nutrient Contribution of Soils and Riparian}

Areas-Another background condition that is critical to the question of nonpoint nutrient loading, particularly from areas managed for timber, is the nutrient status of soils in the forest and their propensity to release nutrients after disturbances (timber harvests, fertilization, or fires). Furthermore, it is assumed that an important route for nutrients entering tributaries and the main stem is through the hyporheic zones along the riparian margins of the river (Triska, Kennedy, and others, 1989; Triska, Duff, and Avanzino, 1989). Because entering nutrients are most likely consumed and recycled by the benthic community (Paul and others, 1991), they can be under represented or missing in water-column samples (Welch and others, 1989; Tanner and Anderson, 1996), and yet they may contribute significantly to algal growth. A study of nutrient hyporheic processing, and evaluation of additional inputs to the system from forested areas before and after disturbances, would aid in management of both riparian areas and timber operations.

\section{Nutrient Status and Limitation}

An important question to arise from the studies to date is that of nutrient limitation in the river and the effects of nutrient inputs on algal communities. The river appears severely nitrogen limited, such that increased nitrogen inputs would likely result in additional algal growth. Depending on the location and the form of nitrogen introduced, such inputs can simply add biomass (Stockner and Shortreed, 1988; Peterson and Grimm, 1992), increase production rates of secondary consumers (see Steinman, 1996, for a review of algal-grazer interactions), change the species composition of the algal community (Marcus, 1980; Peterson and Grimm, 1992; Blomqvist and others, 1994), or some combination of these effects. With the abundance of nitrogen fixers at various locations in the river (fig. 8), however, it is possible that algae at those locations would respond to additions of phosphorus regardless of nitrogen levels. In effect, nitrogen and phosphorus could be colimiting in places. There are several ways in which nutrient dynamics in the river could be investigated. These include further definition or confirmation of existing temporal and spatial patterns of nutrients in the river basin, studies of algal response to nutrient additions (either in-place or in laboratories), nutrient spiraling and uptake (reviewed by Mullholland, 1996), and the use of isotopes to trace pathways of nitrogen in streams, reservoirs, or soils (Faure, 1986; Kendall and others, 1995). Because algae may respond to even very low concentrations of nitrogen, future nutrient studies should use laboratory methods that reliably detect such low nitrogen concentrations, including those for organic nitrogen and ammonia.
Temporal and spatial patterns-Data-collection efforts have clarified several basic aspects of the nutrient dynamics of the North Umpqua River Basin. Stream-chemistry data show that nitrogen is an important nutrient within the entire system, and water-quality and algal community data imply that nutrient processing in the reservoirs has a variety of effects downstream. Alternative sources of nitrogen, such as algal fixation or heterotrophic consumption of organic nitrogen, are now known to contribute to the nitrogen budget for the river. The magnitude and importance of short- and long-term changes in nitrogen concentrations, and how the benthic community responds to these changes, however, are not known. The synoptic survey in 1995 focused on low-flow, worst-case conditions to assess the magnitude of algal problems. Early spring nutrient and flow conditions could be equally important in establishing algal growth and successional patterns at some sites. Diel fluctuations in nutrient concentrations, including releases from reservoirs, could expose algae to available nutrients for sufficient periods for algae to sequester the necessary nutrients. Thus, algae could be able to metabolize and grow, despite the generally low concentrations. Of critical importance in this report is the processing of incoming nutrients in the reservoirs, both in the water column and at the sediment water interface, and the possibility that the reservoirs are exporting ecologically relevant concentrations of organic nitrogen at concentrations lower than traditional field and laboratory methods have been able to distinguish. Many of these issues could be incorporated into a fixed duration (1 to 2 year) monitoring program that would better define nutrient concentrations at strategic locations throughout a complete hydrologic cycle.

Nutrient Addition-Nutrient addition experiments offer a potentially valuable method to determine the response of the North Umpqua River to different management alternatives, however, there are potential obstacles to instream types of experimental manipulations owing to the Wild and Scenic designation of the main stem and endangered species considerations. Laboratory or streamside studies of algal productivity under different nutrient regimes would help determine the status of nutrient limitation (nitrogen or phosphorus) and the importance of alternative nutrient sources (fixation and heterotrophy). Responses of the algal community to nutrient inputs, and the effect of such inputs on the food web, could be evaluated. Benthic recycling, nutrient spiraling lengths, and nutrient uptake rates could be quantified to examine the effects of nutrient inputs through ground water, hyporheic zones, and within or through reservoirs.

Isotopes-Isotopes could be used to trace pathways of nutrient movement and recycling in the North Umpqua River. Ratios of naturally occurring isotopes of nitrogen and oxygen can be used to determine sources of nutrients (Kendall and others, 1995), particularly if the sources are isotopically distinct, such as storm runoff, sewage (from septic systems near Toketee Lake, Lemolo Lake recreational facilities, or from sewage lagoons near Diamond Lake), fertilizers, and instream or reservoir sources. There might be an exchange of water from Lake Creek or Diamond Lake into the upper North Umpqua River above Lemolo Lake (INLET) through volcanic rocks underlying the pumice flat. Road building and logging could also contribute to the high nutrient concentrations observed at INLET; the use of isotopes may help discern the nutrient sources at this location. Isotopes of 
nitrogen and carbon can also be used to investigate algal productivity and nutrient uptake rates, cycling, and transfer to higher trophic levels (Peterson and others, 1993), and could be combined with other manipulations in selected reaches of the North Umpqua River to examine effects of disturbance (Wooten and others, 1996) or food-web interactions.

\section{Geomorphology}

The effects of geomorphic structure in the North Umpqua River Basin and potential changes from management of forests or the hydroelectric system, and potential changes could be manifested in effects on channel complexity, sedimentation rates, sediment substrate size classes, riparian vegetation, and potential influences of these aspects on $\mathrm{pH}$ through hyporheic processes. Studies to define the original stream morphology and to map the current streambed are currently underway as part of PacifiCorp's watershed analysis (PacifiCorp, 1997). Results of this study could provide a context for discussions of the effects of changes in the river's physical structure resulting from forestry, road construction, and the addition of reservoirs.

One of the questions that has received the most attention in recent years is the effect of stream morphology, nutrient status, and algal growth on $\mathrm{pH}$ in the North Umpqua River Basin. High $\mathrm{pH}$ values (above 8.5) have been recorded throughout the basin and appear to be associated with the low overall channel complexity. The low alkalinities of streams in the basin (approximately $30 \mathrm{mg} / \mathrm{L}$ as $\mathrm{CaCO}_{3}$ ) contribute to the susceptibility of the water to $\mathrm{pH}$ perturbations; however, alkalinity is the result of mineral weathering in the soils and is not likely to increase in response to human activities. Nonetheless, if hypotheses linking streambed production and respiration (and their effects on $\mathrm{pH}$ ) to channel morphology prove accurate, then the factors that contribute to high $\mathrm{pH}$ should theoretically be reversible. These factors include shade reduction by removal of riparian vegetation, nutrient inputs resulting from forestry practices, channel widening resulting from scour and flooding induced by road building and removal of LWD, loss of gravel resulting from channel simplification, and reduction of delivery of terrestrial organic materials. As a demonstration project, it would be instructive to attempt to induce some of these changes, and likewise to attempt to reverse the process, in selected areas. The effects on algal growth and water quality (including $\mathrm{pH}$ ) could be measured over time as channel integrity is restored. Demonstration of the cause and reversal of these processes would be invaluable to timber and water managers throughout the Pacific Northwest.

\section{Reservoir Processing}

The effect of reservoirs on water quality in the North Umpqua River Basin is a question of great significance. As the single most important factor regulating year round sediment delivery, and summer flow to the Wild and Scenic reach, and, most likely, water-quality characteristics such as summer water temperature and nutrient concentrations in the Wild and Scenic reach, the reservoirs undoubtedly have an effect on many aspects of the river's ecology in downstream areas (Ward and Stanford, 1983a). In all likelihood these effects extend from algal produc- tion to invertebrate communities and, possibly, to both resident and anadromous fishes. There are many ways in which the effects of the reservoirs could continue to be evaluated. Only a few of the possible studies relating to the impacts of reservoirs on downstream reaches are suggested here. These include examinations of sedimentation in and sediment transport from the reservoirs, pathways of nutrients entering and exiting the reservoirs, distribution of CPOM and FPOM upstream and downstream from the reservoirs, and the effects of the reservoirs on stream temperature. A comparison of benthic invertebrate functional communities upstream and downstream from the reservoirs would also be valuable. This could be evaluated experimentally through the use of litter bags or enclosures at selected locations to determine the presence or absence of different feeding groups.

\section{Primary Production and Algal Distribution}

Algal production is a key focus of this report and is one of the foremost issues facing water managers in the North Umpqua River Basin. This study has reported the magnitude of algal biomass and the community structure at selected locations, and insights into the processes governing algal growth in the river have been gained. The existing data set remains small, however, and contains several findings that warrant further study. As with stream chemistry, seasonal aspects of algal growth are largely unknown. Information on successional patterns of algal growth and rates of primary production are important for an understanding of food-web processes. Additional spatial coverage of algal measurements within the hydroproject area and other areas (such as Little River or additional main-stem sites) would help to confirm or broaden the understanding of the effects of the reservoir system and forestry on algal growth. Algal growth assays, using waters from various locations, could be performed in a laboratory to assess nutrient limitation and the importance of organic nitrogen. Enclosure or laboratory experiments could be used to measure the contributions of nitrogen fixation, or of periphyton/ grazer relations (such as the reported symbiotic relationship between the blue-green alga Nostoc and Cricotopus chironomid midge), to nutrient concentrations in streams. All of these, and other potential studies, offer opportunities to gain an understanding of the effects of both the reservoirs and forestry on algal growth in the river.

\section{Food-Web Dynamics}

The ultimate success to any water-quality and ecological studies in the North Umpqua River Basin will probably be measured by their ability to sustain, or preferably to strengthen, native fish runs in the basin. Salmonid fishes, both anadromous and resident, are dependent on a variety of food sources. The regulation of aquatic food webs ("top-down" or "bottom-up"; Power, 1992b) in the basin has not been addressed. The significance of a possible shift in the nature of the aquatic food webs, from those based on a mixture of organic detrital and algal forms to those with a greater importance of algal biomass as the primary energy source and less dependence on detrital inputs, is not known. An additional unknown is the effect that such a shift might have on invertebrate herbivores or, ultimately, on fish in 
the system. The role of disturbance (flooding) and flow regulation (Wooten and others, 1996) on algal and invertebrate communities, in bypass reaches as well as the Wild and Scenic reach, is also integral to the understanding of food webs. Several of these studies have been discussed (Mikeal Jones, U.S. Forest Service, oral commun., 1996) or proposed (M. Power, University of California - Berkeley, written commun., 1996) previously. The integration of food-web studies with additional nutrient or primary productivity investigations would be particularly informative.

\section{SUMMARY}

This report describes the results of synoptic water-quality and algal investigations at 36 stream sites in a 1,350-square-mile area of the North Umpqua River Basin, including the Wild and Scenic reach, the hydroproject area, and the Steamboat Creek and Little River watersheds, during 1week in July 1995. Data on streamflow, nutrients, algae, sediment, water temperature, dissolved oxygen, $\mathrm{pH}$, and alkalinity are interpreted to provide a conceptual understanding of the aquatic ecology of the river basin. Additional data collected during 1993 through 1995 by the USGS and during 1992 through 1994 by PacifiCorp were used to extend the temporal and spatial scales of the findings beyond those of the July 1995 data; 1993 reconnaissance data on trace elements and organic compounds in water and bed sediment also are reviewed. Effects of land and water use, including forestry and reservoir operations, on the Wild and Scenic reach are inferred where sufficient data exist.

A mass-balance analysis of streamflow measurements in the Wild and Scenic reach (river mile [RM] 69.2-35.7) indicated that there were no major unmeasured water sources during July 1995, although ground-water input was a possibility in one reach. Summer streamflow in the main stem, which was dominated by releases from the hydroproject area, increased from $923 \mathrm{ft}^{3} / \mathrm{s}$ (cubic feet per second) at the Soda Springs powerhouse (RM 69.2) to approximately $1,280 \mathrm{ft}^{3} / \mathrm{s}$ at the town of Glide. Inputs from three major tributaries (Steamboat Creek, Rock Creek, and the Little River) accounted for 243 of the additional $357 \mathrm{ft}^{3} / \mathrm{s}$ $(68 \%)$ entering the river; measurement error (or possibly groundwater input) accounted for the additional $114 \mathrm{ft}^{3} / \mathrm{s}$ (approximately $10 \%$ difference between measured and estimated) in the North Umpqua River from Steamboat Creek to Rock Creek.

Results of sampling for trace elements in water indicated consistent, low concentrations of arsenic, barium, manganese, and aluminum in filtered water from 1993 through 1995. Arsenic concentrations $(1 \mu \mathrm{g} / \mathrm{L})$ were one-half of the U.S. EPA's Risk Specific Dose Health Advisory of $2 \mu \mathrm{g} / \mathrm{L}$ for drinking water. Because water from the North Umpqua River is used as a drinking-water source by some people, the detected arsenic concentrations are potentially important. Aluminum concentrations in filtered water were much higher at high flow, possibly because some aluminum may have been contained in suspended colloidal material. Other trace elements detected in filtered water at high flow were copper and nickel, both at low concentrations. Bedsediment concentrations of arsenic, chromium, copper, manganese and nickel were approximately double the sediment-quality criteria adopted by New York State and by the Ontario Ministry of the Environment. Bed-sediment samples also had relatively high concentrations of phosphorus compared with values in data bases of trace-element concentrations in streambed sediments and in soils, a result that is in agreement with previous reports that the volcanic soils of the Western Cascades are rich in phosphorus. Arsenic concentrations in bed sediments were moderately high compared with values in available data bases. No synthetic organic compounds were detected in either water (at high or low flow) or bed sediments.

Inorganic and ammonium nitrogen concentrations were undetectable (less than $5 \mu \mathrm{g} / \mathrm{L}$ ) at almost all locations during 1995, whereas soluble reactive phosphorus (SRP) was plentiful (median concentration greater than $20 \mu \mathrm{g} / \mathrm{L}$ at main-stem and hydroproject area sites), indicating strong nitrogen limitation throughout most of the basin. Organic nitrogen concentrations were also near or below the minimum reporting level $(200 \mu \mathrm{g} / \mathrm{L})$; however, they were estimated to be highest at sites downstream from impoundments on the basis of qualitative, uncensored laboratory data. As was the case for streamflow, water released from Soda Springs Reservoir was the major source of phosphorus to the Wild and Scenic reach. Periphytic algal uptake (rather than dilution) appeared to be the cause of reductions of phosphorus concentrations in the Wild and Scenic reach. Because nitrogen could not be measured in the water column despite sometimes prolific algal growth, it is inferred that benthic uptake and rapid recycling of incoming nitrogen mask the true nitrogen transport in the river system. Alternative sources of nitrogen such as fixation and utilization of organic forms by algae may help maintain "nuisance" amounts of periphyton growth, despite the absence of measurable water-column nitrogen. A possible source of sewage to Toketee Lake could help explain high nutrient concentrations and algal assemblages observed downstream from the lake.

Daily maximum water temperatures during July 1995 were higher than $13^{\circ} \mathrm{C}\left(55^{\circ} \mathrm{F}\right)$, the upper limit of the optimal temperature range for steelhead, along the entire Wild and Scenic reach of the main stem downstream to Glide. Flow from the Soda Springs Reservoir was the primary factor determining stream temperatures at main-stem sites in the Wild and Scenic reach, and diel temperature changes were small (less than $1^{\circ} \mathrm{C}$ ). Maximum temperatures in Steamboat Creek, an important tributary for steelhead spawning, were the highest measured during the study $\left(22.5^{\circ} \mathrm{C}\right)$, but temperatures at sites in the main stem downstream from Steamboat Creek and in Little River also approached $20^{\circ} \mathrm{C}$. The highest temperatures in the hydroproject area $\left(18^{\circ} \mathrm{C}\right)$ were recorded upstream from Lemolo Lake at the mouth of Lake Creek, which was also the location of the largest diel temperature change $\left(8^{\circ} \mathrm{C}\right)$ as recorded by PacifiCorp's instream, hourly monitors (PacifiCorp, 1995b). The lowest temperatures were recorded at the mouth of the upper North Umpqua River upstream from Lemolo Lake (INLET) and in the Clearwater River upstream from Stump Lake $\left(4.5^{\circ} \mathrm{C}\right.$ and $4.0^{\circ} \mathrm{C}$, respectively), both of which are apparently strongly affected by ground water (PacifiCorp, 1995b).

For the most part, dissolved-oxygen concentration (DO) was controlled by water temperature and physical reaeration more than by primary production. The only sites at which the DO concentrations were lower than the State of Oregon standard in effect during 1995 (95\% saturation) were Steamboat Creek above Big 
Bend Creek, Lake Creek at the mouth, and the North Umpqua River above Copeland Creek. In many locations, DO concentrations were higher in the morning and lower in the afternoon as a result of diel stream warming. Water entering the Wild and Scenic reach was strongly aerated by the violent turbulence in the tailrace of the Soda Springs powerhouse such that minimum DO saturation was 109 percent. The high stream gradient and frequent riffles maintain physical reaeration throughout the Wild and Scenic reach. Reaeration appeared to be especially dominant in tailraces below powerhouses-minimum saturation below the Lemolo No. 2 powerhouse was 98 percent despite prolific periphyton growth at that site.

Periphyton growth had a more pronounced effect on $\mathrm{pH}$ than on DO, possibly because alkalinity in the river is relatively low (approximately $30 \mathrm{mg} / \mathrm{L}$ as $\mathrm{CaCO}_{3}$ ). Daily maximum $\mathrm{pH}$ exceeded the State of Oregon Standard of $8.5 \mathrm{pH}$ units at one main-stem site (the North Umpqua River near Glide), two tributary sites below the hydroproject area (Steamboat Creek near the Mouth and the Little River above Wolf Creek), and one site in the hydroproject area (North Umpqua full-flow reach below the Lemolo No. 2 powerhouse). Water at several sites also had a maximum $\mathrm{pH}$ of 8.4 , and may have exceeded 8.5 on other days or at other times than the sampling occurred. A diel change of 1.2 $\mathrm{pH}$ units was recorded in the full-flow reach below the Lemolo No. 2 powerhouse, whereas the diel changes in the Wild and Scenic reach increased from 0.4 to $0.8 \mathrm{pH}$ units from the Soda Springs powerhouse to Rock Creek.

Data from an hourly monitor located upstream from Rock Creek, at the terminus of the Wild and Scenic reach, indicated that conditions the week of the synoptic survey during July 1995 were a good approximation of worst-case conditions for all of 1995. Water temperature, DO concentration, and $\mathrm{pH}$ were near their maximum, minimum, and maximum daily values for the season, respectively. Furthermore, comparison of the monitor record with cross-sectional data collected at the fixed water-sample collection site located 0.2 miles upstream indicated that measurements from the monitor were within $0.5^{\circ} \mathrm{C}$ and $0.2 \mathrm{pH}$ units in all nine cases (spanning the range of flow and temperature conditions) available for comparison between 1993 and 1995. Differences in DO concentrations between the two sites were within 0.7 $\mathrm{mg} / \mathrm{L}$ in all seven cases where comparisons could be made, despite the two large riffles located between the fixed site and the monitor location. Much of the monitor record was missing, however, from 1993 through 1995 because of mechanical difficulties associated with sediment clogging of water pumps used by the monitor.

Results of algal investigations indicated that periphyton biomass and biovolume were highest at sites located directly downstream from reservoirs, but that biomass at main-stem sites was higher than expected for such a low-nutrient river. Periphyton chlorophyll $a$ correlated well with SRP concentrations, a finding that is contrary to the apparent nitrogen limitation of the river. This correlation may, however, be a statistical artifact caused by the large algal growths at hydroproject affected sites, where concentrations of phosphorus were highest. A total of 99 algal taxa from 5 Divisions were identified in samples from the 10 sampling locations. More than $90 \%$ of the algal taxa identified among all sites were diatoms, with blue-green algae and green algae each comprising $4 \%$ of the taxa. Blue-green algae were most abundant at main-stem sites and at the mouth of Steamboat Creek, and were observed at all sites except below Toketee and Lemolo Lakes. Many of the blue-green taxa observed have the ability to fix nitrogen. In addition, two diatom genera in the family Epithemiaceae, which contains blue-green algae that live inside the host cells symbiotically, were abundant at six sites. This endosymbiont has been shown to fix nitrogen. The abundance of blue-green algae and the diatoms with nitrogen fixing inclusions is further evidence of nitrogen limitation in several parts of the river.

Classification of diatoms into autecological guilds that are reflective of water-quality conditions indicated that, among all sites sampled, alkaliphilic taxa (preferring $\mathrm{pH}$ greater than 7), nitrogen-fixing taxa, and eutrophic taxa (indicative of organic and nutrient enrichment) were the most abundant on the basis of biovolume and density. The remainder of the diatoms comprised cold-water taxa (preferring water temperatures less than $15^{\circ} \mathrm{C}$ ), nitrogen heterotrophs (which have the ability to use organic nitrogen as a source of both nitrogen and energy), and oligotrophic taxa. Biovolumes of nitrogen-fixing species (including both heterocystous blue greens and epithemiacean diatoms) were highest at four main-stem sites (downstream from the Soda Springs powerhouse, at the Copeland gage, downstream from Steamboat Creek, and at the fixed site upstream from Rock Creek) and at both sites in Steamboat Creek, but were less abundant at the hydroproject area sites (downstream from Lemolo and Toketee Lakes) and tributaries upstream from Lemolo Lake. The sites downstream from Lemolo and Toketee Lakes had large amounts of eutrophic taxa, which were also prevalent at Steamboat Creek upstream from Big Bend Creek and at the inflow to Lemolo Lake on the upper North Umpqua River. Nitrogen heterotrophs were also abundant downstream from reservoirs (downstream from Lemolo and Toketee Lakes). Alkaliphilic taxa were most significant in the North Umpqua River upstream from and downstream from Lemolo Lake, downstream from Toketee Lake, downstream from Soda Springs powerhouse, and in Steamboat Creek upstream from Big Bend Creek; however, only at Lake Creek were alkaliphilic taxa less than $27 \%$ of the biovolume.

In general, the periphyton communities observed in this study are characteristic of those found in alkaline waters with moderate to nuisance-level nutrient enrichment. Results of analyses using two multivariate methods (TWINSPAN and CCA) and the autecological guild approach indicate that algal communities at the hydroproject sites are distinct from those at the main-stem and Steamboat Creek sites. Algal communities at the hydroproject sites were primarily composed of eutrophic taxa, nitrogen heterotrophic taxa, and filamentous green algae, whereas the main-stem and Steamboat Creek sites had a high abundance of nitrogen-fixing taxa, and were indicative of warmer water temperatures, higher $\mathrm{pH}$ values, selective grazing by herbivores, and lack of scouring high flows. The development of significant grazer-resistant blue-green algal populations in the Wild and Scenic reach and Steamboat Creek has potential implications for food webs in the river; however, these relations have not been examined. 
On the basis of data and information from the literature presented in this report, a conceptual model describing water quality and stream ecology of the river is proposed. Algal-community and water-quality data indicate that the hydroproject located in the headwaters of the North Umpqua River, with its eight structural developments (diversion dams, powerhouses, and impoundments) and 37.3 miles of waterways and penstocks, has a major impact on the water quality and ecological functioning of the river. In effect, the reservoirs appear to interfere with the natural gradient of physical processes (Ward and Stanford, 1983a; Vannote and others, 1980) of the river. Downstream transport of sediments and organic matter is interrupted, and these materials are probably deposited in the reservoirs. Microbial and algal processing of both organic and inorganic matter are most likely occurring in both the sediments and the water column of the reservoirs, decreasing the ratio of coarse- to fine-grained particulate organic matter in the reservoir releases. Changes in the flow regime, the frequency of disturbance, and the sediment and scour processes associated with them have possibly changed the prevalence of various invertebrate functional feeding groups (Wooten and others, 1996). Furthermore, these processes could have fundamentally shifted the base of food webs downstream from the reservoirs, increasing the importance of benthic algae as a food source for aquatic invertebrates and changing the types of food available to higher trophic levels such as fish.

Forestry practices also could have contributed to these changes; however, from the data collected in this study, their effects are not as evident as those of the hydropower project. Possible effects from forestry practices in the North Umpqua River include changes in magnitude and timing of streamflow, decreases in channel complexity, increases in nutrient inputs, reductions in riparian cover and riparian contributions of organic matter to streams, and increases in stream temperature. Some of these effects are evident in the Steamboat Creek and Little River watersheds, which are unaffected by hydroproject operations but are heavily managed for timber.

This conceptual model could be modified or potentially verified by additional data collection and analyses. Results of such studies could allow more effective management of the resources in the North Umpqua River Basin.

\section{REFERENCES CITED}

Adams, P.W., and Stack, W.R., 1989, Streamwater quality after logging in Southwest Oregon, Project completion report supplement number PNW 87-400, U.S. Forest Service, Pacific Northwest Research Station, Portland, Oregon, $36 \mathrm{p}$.

Allen, D.J., 1995, Stream ecology-Structure and function of running waters: New York, Chapman and Hall, 388 p.

American Public Health Association, 1989, Standard Methods for the Examination of Water and Wastewater (17th ed.): Washington, D.C., American Public Health Association, $1136 \mathrm{p}$.

Arbogast, B.F., ed., 1990, Quality assurance manual for the Branch of Geochemistry: U.S. Geological Survey Open-File Report 90-668, 184 p.
Bahls, L.L., 1993, Periphyton bioassessment methods for Montana streams: Helena, Montana, Water Quality Bureau, Montana Department of Health and Environmental Sciences, $62 \mathrm{p}$.

Bahls, L.L. and Weber, E.E., 1988. Ecology and distribution in Montana of Epithemia sorex Kutz.-A common nitrogen-fixing diatom: Proceedings of the Montana Academy of Sciences, v. 48, p. 15-20.

Bakke, P.D., and Pyles, M.R., 1997, Predictive model for nitrate load in the Bull Run Watershed, Oregon: Journal of the American Water Resources Association, v. 32, no. 4, p. 897-906.

Biggs, B.J.F., 1996, Patterns in benthic algae in streams, in Stevenson, J.R., Bothwell, M.L., and Lowe, R.L. (eds.), Algal Ecology, Freshwater Benthic Ecosystems: San Diego, California, Academic Press, Inc., p. 31-56.

Bjornn, T.C., and Reiser, D.W., 1991, Habitat requirements of salmonids in streams, in Meehan, W.R., ed., Influences of forest and rangeland management on salmonid fishes and their habitats, American Fisheries Society, Bethesda, MD, Special Publication 19, p. 83-138.

Bjornsen, P.K., 1988, Phytoplankton exudation of organic matter-Why do healthy cells do it?: Limnology and Oceanography, v. 33, no. 1, p. 151-154.

Blomqvist, P., Pettersson, A., and Hyenstrand, P., 1994, Ammonium nitrogen-A key regulatory factor causing dominance of non-nitrogen fixing cyanobacteria in aquatic systems: Archives fur Hydrobiologia, v. 132, no. 2, p. 141-164.

Bonoff, M.B., Mattax, B.L., and Olson, T.M., 1996, Diel study of Lemolo Lake, Douglas County, Oregon: Northwest Science, v. 70, Special Issue no. 2, p. 48-57.

Borchardt, M.A., 1996, Nutrients, in Stevenson, J.R., Bothwell, M.L., and Lowe, R.L., eds., Algal ecology-Freshwater benthic ecosystems: San Diego, California, Academic Press, Inc., p. 183-227.

Bothwell, M.L., 1988, Growth rate responses of lotic periphyton diatoms to experimental phosphorus enrichment-The influence of temperature and light: Canadian Journal of Fisheries and Aquatic Sciences, v. 45, p. 261-270.

Bourdier, G., Bohatier, J., Feuillade, M., and Feuillade, J., 1989, Amino acid incorporation by a natural population of Oscillatoria rubescens-A microautoradiographic study: FEMS Microbiology Ecology, v. 62, p. 185-190.

Braak, C.J.F. ter, 1986, Canonical correspondence analysis-A new eigenvector technique for multivariate direct gradient analysis: Ecology, v. 67, p. 1667-1679.

Brock, E.M., 1960, Mutualism between the midge Cricotopus and the alga Nostoc: Ecology, v. 41, p. 474-483.

Buchanan, T.J., and Somers, W.P., 1984, Discharge measurements at gaging stations: U.S. Geological Survey Techniques of Water-Resources Investigations, book 3, chapter A8, $65 \mathrm{p}$.

Carrick, H.J., Lowe, R.L., and Rotenberry, J.T., 1988, Guilds of benthic algae along nutrient gradients-Relationships to algal community diversity: Journal of the North American Benthological Society, v. 7, no. 2, p. 117-128. 
Cazaubon, A., Rolland, T., and Loudiki, M., 1995, Heterogeneity of periphyton in French Mediterranean rivers: Hydrobiologia, v. 300/301, p. 105-114.

Chamberlain, T.W., Harr, R.D., and Everest, F.H., 1991, Timber harvesting, silviculture, and watershed processes, in Influences of forest and rangeland management on salmonid fishes and their habitats, W.R. Meehan, ed., American Fisheries Society, Bethesda, MD: Special Publication 19, p. 181-205.

Chapra, S.C., 1981, Application of phosphorus loading models to river-run lakes and other incompletely mixed systems, in United States Environmental Protection Agency: Restoration of lakes and inland waters, EPA 440/ 5-281-010, p. 329-334.

Christie, C.E., and Smol, J.P., 1996, Limnological effects of 19th century canal construction and other disturbances on the trophic state history of Upper Rideau Lake, Ontario: Lake and Reservoir Management, v. 12, no. 4, p. 448-454.

Clifton, D.G., 1985, Analysis of biological data collected in the Bull Run Watershed, Portland, Oregon, 1978 to 1983: U.S. Geological Survey Water-Resources Investigations Report 85-4245, 62 p.

Collier, M., Webb, R.H., and Schmidt, J.C., 1996, Dams and rivers - A primer on the downstream effects of dams: U.S. Geological Survey Circular 1126, 94 p.

Cuffney, T.F., Meador, M.R., Porter, S.D., and Gurtz, M.E., 1997, Distribution of fish, benthic invertebrate, and algal communities in response to physical and chemical conditions, Yakima River Basin, Washington, 1990: U.S. Geological Survey Water-Resources Investigations Report 96-4280, 94 p.

Dam, H. van, Mertens, A., and Sinkeldam, J, 1994, A coded checklist and ecological indicator values of freshwater diatoms from the Netherlands: Netherlands Journal of Aquatic Ecology, v. 28, no. 1, p. 117-133.

DeAngelis, D.L., 1992, Dynamics of nutrient cycling and food webs-Volume 9 of Population and community biology: London, Chapman and Hall, p. 270.

DeYoe, H.R., Lowe, R.L., and Marks, J.C., 1992. Effects of nitrogen and phosphorus on the endosymbiont load of Rhopalodia gibba and Epithemia turgida (Bacillariophyceae): Journal of Phycology, v. 28, p. 773777.

Dillon, P.J., and Kirchner, W.B., 1975, The effects of geology and land use on the export of phosphorus from watersheds: Water Research, v. 9, p. 135-148.

Dixit, S.S., and Smol, J.P., 1994, Diatoms as indicators in the Environmental Monitoring and Assessment ProgramSurface waters (EMAP-SW): Environmental Monitoring and Assessment, v. 31, p. 275-306.

Dixit, S.S., Smol, J.P., and Kingston, J., 1992, Diatoms: powerful indicators of environmental change: Environmental Science and Technology, v. 26, p. 23-33.

Dodds, W.K., and Gudder, D.A., 1992, The ecology of Cladophora: Journal of Phycology, v. 28, p. 415-427.

Dodds, W.K., Gudder, D.A., Mollenhaur, D., 1995, The Ecology of Nostoc: Journal of Phycology, v. 31, p. $2-18$.
Dodds, W.K., and Marra, J., 1989, Behaviors of the midge Cricotopus (Diptera:Chironomidae) related to mutualism with Nostoc parmelioides (Cyanobacteria): Aquatic Insects, v. 11, p. 201-208.

Dose, J. J., and Roper, B.R., 1994, Long-term changes in low flow channel widths within the South Umpqua Watershed, Oregon: Water Resources Bulletin, v. 30, no. 6, p. 9931000.

Doyle, M.C., and Caldwell, J.M., 1996, Water-quality, streamflow, and meteorological data for the Tualatin River Basin, Oregon, 1991-93: U.S. Geological Survey Open-File Report 96-173, 49 p.

Dufford, R.G., Zimmerman, L.D., Cline, L.D., and Ward, J.V., 1987, Responses of epilithic algae to regulation of Rocky Mountain Streams, in Craig, J.F., and Kemper, J.B., eds., Regulated Streams - Advances in Ecology: Plenum Press, N.Y., p. 383-390.

Edwards, T.K., and Glysson, D.G., 1988, Field methods for measurement of fluvial sediment: U.S. Geological Survey Open-File Report 86-531, 118 p.

Elwood, J.W., Newbold, J.D., Trimble, A.F., and Stark, R.W., 1981, The limiting role of phosphorus in a woodland stream ecosystem-Effects of $\mathrm{P}$ enrichment on leaf decomposition and primary producers: Ecology, v. 62, no. 1, p. 146-158.

Fairchild, G.W., Lowe, R.L., and Richardson, W.B., 1985, Algal periphyton growth on nutrient-diffusing substrates-An in situ bioassay: Ecology, v. 66, no. 2, p. 465-472.

Faure, G., 1986, Principles of isotope hydrology, 2d ed.: New York, John Wiley and Sons, 589 p.

Fausch, K.D., and Northcote, T.G., 1992, Large wood and salmonid habitat in a small coastal British Columbia stream: Canadian Journal of Aquatic Fisheries and Aquatic Sciences, v. 49, p. 682-693.

Fishman, M.J., ed., 1993, Methods of analysis by the U.S. Geological Survey National Water-Quality LaboratoryDetermination of inorganic and organic constituents in water and fluvial sediments: U.S. Geological Survey Open-File Report 93-125, 217 p.

Fitzgerald, G.P., 1969, Some factors in the competition or antagonism among bacteria, algae, and aquatic weeds: Journal of Phycology, v. 5, p. 351-359.

Floener, L., Bothe, H., 1980, Nitrogen fixation in Rhopalodia gibba, a diatom containing blue-greenish inclusions symbiotically, in Schwemmler, W., and Schenk, H.E.A., eds., Endocytobiology, endosymbiosis, and cell biology: Walter de Gruyter and Company, Berlin, p. 541-552.

Fogg, G.E., Stewart, W.D.P., Fay, P., and Walsby, A.E., 1973, The blue-green algae: New York, Academic Press, Inc., 249 p.

Foreman, W.T., Connor, B.F., Furlong, E.T., Vaught, D.G., and Merten, L.M., 1995, Methods of analysis by the U.S. Geological Survey National Water Quality LaboratoryDetermination of organochlorine pesticides and polychlorinated biphenyls in bottom sediment by dual capillary-column gas chromatography with electron-capture detection: U.S. Geological Survey Open-File Report 95-140, 78 p. 
Fredricksen, R.L, 1971, Comparative chemical water quality Natural and disturbed streams following logging and slash burning, in Hall, J.D., and Krygier, J.T., eds., Proceedings of the symposium on forested land uses and stream environment, Corvallis, Oregon State University, p. 125-137.

Fuhrer, G.J., McKenzie, S.W., Rinella, J.R., Sanzalone, R.F., and Skach, K.S., 1994, Surface water-quality assessment of the Yakima River Basin in Washington-Analysis of major and minor elements in fine grained streambed sediment, 1987: U.S. Geological Survey Open-File Report 93-30, 131 p., 3 pls.

Graham, J.M., Auer, M.T., Canale, R.P., and Hoffman, J.P., 1982, Ecological studies and mathematical modelling of Cladophora in Lake Huron-4. Photosynthesis and respiration as functions of light and temperature: Journal of Great Lakes Research, v. 8, no. 1, p. 100-111.

Greene, J.C., 1996, Evaluation of the effects of forest management on water quality in the South Umpqua Experimental Forest watersheds, Oregon [abs.]: Sunriver, Oregon, Chapman Conference on Nitrogen Cycling in Forested Catchments.

Gregory, S.V., 1993, Willamette River Basin study-Periphyton algal dynamics [Final Report to Oregon Department of Environmental Quality]: Corvallis, Oregon State University, $112 \mathrm{p}$.

Guy, H.P., 1969, Laboratory theory and methods of sediment analysis: U.S. Geological Survey Techniques of Water-Resources Investigations, book 5, chapter C1, 58 p.

Heede, B.H., 1972, Influences of a forest on the hydraulic of two mountain streams: Water Resources Bulletin, v. 27, p. 503-511.

Hellebust, J.A., Lewin, J., 1977, Heterotrophic nutrition, in Werner, D., ed., The biology of diatoms: Blackwell Scientific Publications, Oxford, p. 169-197.

Hill, M.O., 1979, TWINSPAN-A FORTRAN program for arranging multivariate data in an ordered two-way table by classification of individuals and attributes: Ithaca, N.Y., Department of Ecology and systematics, Cornell University, $90 \mathrm{p}$.

Hinkle, S.R., 1997, Quality of shallow ground water in alluvial aquifers of the Willamette River Basin, Oregon, 1993-95: U.S. Geological Survey Water-Resources Investigations Report 97-4082-B, 48 p.

Holaday, S.A., 1992, Summertime water temperature trends in Steamboat Creek Basin, Umpqua National Forest: Corvallis, Oregon State University M.S. Thesis, 128 p.

Horner, R.R., Welch, E.B., and Veenstra, R.B., 1983, Development of nuisance periphytic algae in laboratory streams in relation to enrichment and velocity, in Wetzel, R.G., ed., Periphyton of freshwater ecosystems: The Hague, Dr. W. Junk Publishers, p. 121-134.

Horowitz, A.J., Demas, C.R., Fitzgerald, K.K., Miller, T.M., and Rickert, D.A., 1994, U.S. Geological Survey protocol for the collection and processing of surface-water samples for the subsequent determination of inorganic constituents in filtered water: U.S. Geological Survey Open-File Report 94-539, $57 \mathrm{p}$.
Jobling, M., 1981, Temperature tolerance and the final preferendum-Rapid methods of the assessment of optimum growth temperatures: Journal of Fish Biology, v. 19, p. 439-455.

Johnson, D. M., Petersen, R.P., Lycan, D.R. Sweet, J.W., Neuhaus, M.E., and Schaedel, A.L., 1985, Atlas of Oregon lakes: Corvallis, Oregon State University Press, 317 p.

Jones, J.A., and Grant, G.E., 1996, Peak flow responses to clear-cutting and roads in small and large basins-Western Cascades, Oregon: Water Resources Research, v. 32, no. 4, p. 959-974.

Jongman, R.H.G., ter Braak, C.J.F., and van Tongeren, O.F.R., 1995, Data analysis in community and landscape ecology: Pudoc, Wageningen, The Netherlands, Cambridge University Press, 299 p

Kendall, C., Sklash, M. G., and Bullen, T.D., 1995, Isotope tracers of water and solute sources in catchments: in Trudgill, S.T., ed., Solute modelling in catchment systems: New York, John Wiley and Sons Ltd., p. 261-303.

Kennedy, E.J., 1983, Computation of continuous records of streamflow: U.S. Geological Survey Techniques of Water-Resources Investigations, book 3, chapter A13, p. 53.

Kennedy, R.H., and Walker, W.W., 1990, Reservoir nutrient dynamics, in Thornton, K.W., Kimmel, B.L., and Payne, F.E., eds., Reservoir limnology: New York, John Wiley and Sons, Inc., p. 109-131.

Kutka, F.J., and Richards, C., 1996, Relating diatom assemblage structure to stream habitat quality: Journal of the North American Benthological Society, v. 15, no. 4, p. 469-480.

Kuwabara, J.S., 1992, Associations between benthic flora and diel changes in dissolved arsenic, phosphorus, and related physicochemical parameters: Journal of the North American Benthological Society, v. 11, no. 2, p. 218-228.

Lamberti, G.A., 1996, The role of periphyton in benthic food webs, in Stevenson, J.R., Bothwell, M.L., and Lowe, R.L., eds., Algal ecology_Freshwater benthic ecosystems: San Diego, California, Academic Press, Inc., p. 533-573.

Leland, H.V., 1995, Distribution of phytobenthos in the Yakima River Basin, Washington, in relation to geology, land use, and other environmental factors: Canadian Journal of Fisheries and Aquatic Sciences, v. 52, p. 1108-1129.

Ligon, F.K., Dietrich, W.E., and Trush, W.J., 1995, Downstream ecological effects of dams-A geomorphic perspective: BioScience, v. 45, no. 3, p. 183-192.

Lowe, R.L., 1974, Environmental requirements and pollution tolerances of freshwater diatoms: U.S. Environmental Protection Agency, Environmental Monitoring Series 670/ 4-74-005, Washington, D.C., American Health Association, 1136 p., 334 p.

Lowe, R.L., and Pan, Y., 1996, Benthic algal communities as biological monitors, in Stevenson, J.R., Bothwell, M.L., and Lowe, R.L., eds., Algal ecology, freshwater benthic ecosystems: San Diego, California, Academic Press, Inc., p. 705-739.

Marcus, M.D., 1980, Periphytic community response to chronic nutrient enrichment by a reservoir discharge: Ecology, v. 61 , no. 2, p. 387-399. 
Marshall, D.B., Chilcote, M., and Weeks, H., 1996, Species at risk-Sensitive, threatened, and endangered vertebrates of Oregon (2d ed.): Portland, Oregon Department of Fish and Wildlife, [variously paged].

Marston, R.A., 1982, The geomorphic significance of log steps in forest streams: Annals of the American Association of Geographers, v. 72, p. 99-108.

McFarland, W.D., 1983, A description of aquifer units in western Oregon: U.S. Geological Survey Open-File Report 82$165,35 \mathrm{p}$.

McKee, B., 1972, Cascadia-The geological evolution of the Pacific Northwest: New York, McGraw Hill, 394 p.

Meador, M.R., Hupp, C.R., Cuffney, T.F., and Gurtz, M.E., 1993, Methods for characterizing stream habitat as part of the National Water Quality Assessment Program: U.S. Geological Survey Open-File Report 93-408.

Meehan, W.R., ed., 1991, Influences of forest and rangeland management on salmonid fishes and their habitats: Bethesda, Maryland, American Fisheries Society, Special Publication 19, $751 \mathrm{p}$.

Meyer, J.L., and Likens, G.E., 1979, Transport and transformation of phosphorus in a forested stream ecosystem: Ecology, v. 60 , p. $1255-1269$.

Moffatt, R.L., Wellman, R.E., and Gordon, J.M., 1990, Statistical summaries of streamflow data in Oregon: Volume 1Monthly and annual streamflow, and flow duration values: U.S. Geological Survey Open-file Report 90-118, 413 p.

Moore, D.G., 1971, Fertilization and water quality, in Proceedings of the Western Forestry and Conservation Association annual meeting, Portland, Oregon, p. 1-4.

Mulholland, P.J., 1992, Regulation of nutrient concentrations in a temperate forest stream-Roles of upland, riparian, and instream processes: Limnology and Oceanography, v. 37, no. 7 , p. $1512-1526$.

1996, Role in nutrient cycling in streams, in Stevenson, J.R., Bothwell, M.L., and Lowe, R.L., eds., Algal ecology_Freshwater benthic ecosystems: San Diego, California, Academic Press, Inc., p. 609-639.

Murphy, M.L., and Meehan, W.R., 1991, Stream ecosystems, in W.R. Meehan, ed., Influences of forest and rangeland management on salmonid fishes and their habitats: Bethesda, Maryland, American Fisheries Society, Special Publication 19, p. 17-46.

Nakama, L.Y., and Risley, J.C., 1993, Use of a rainfall-runoff model for simulating the effects of forest management on streamflow in the East Fork Lobster Creek Basin, Oregon: U.S. Geological Survey Water-Resources Investigations Report 93-4040, 40 p.

New York State Department of Environmental Conservation, 1994, Technical guidance for screening contaminated sediment: Albany, New York State Department of Environmental Conservation, Division of Fish and Wildlife, $36 \mathrm{p}$.

Norris, L.A., Lorz, H.W., and Gregory, S.V., 1991, Forest chemicals, in W.R. Meehan, ed., Influences of forest and rangeland management on salmonid fishes and their habitats: Bethesda, Maryland, American Fisheries Society, Special Publication 19, p. 207-296.
Odum, H.T., 1956, Primary productivity in flowing waters: Limnology and Oceanography, v. 1, no. 2, p. $102-117$.

Oregon Department of Environmental Quality, 1990, Oregon interim sediment-quality guidelines: Portland, Oregon, Issue Paper no. 12, 6 p.

1995, Coast Fork water quality report-Total maximum daily load program: Portland, Oregon, Department of Environmental Quality 38 p.

1996, Oregon Draft 1994/1996 list of water quality limited water bodies-303(d)(1): Portland, Oregon, Department of Environmental Quality, [variously paged].

PacifiCorp, 1994a, Summary Information-Final technical report for water quality, North Umpqua Hydroelectric Project, FERC Project No. 1927: Portland, Oregon, PacifiCorp, $23 \mathrm{p}$.

1994b, Draft application for new license for major modified project-Volume 1-Executive summary, North Umpqua Hydroelectric Project, FERC Project No. 1927: Portland, Oregon, PacifiCorp, 45 p.

1995a, Application for new license for major modified project-Final technical report for water quality, North Umpqua Hydroelectric Project, FERC Project No. 1927: Portland, Oregon, PacifiCorp, Volumes 1-42,[variously paged].

1995b, Diel water quality study-North Umpqua Hydroelectric Project: FERC No. 1927, [variously paged].

1997, The North Umpqua cooperative watershed analyses-Synthesis report-Preliminary working document, North Umpqua Hydroelectric Project, PERC Project No. 1927: Portland, Oregon, PacifiCorp, [variously paged].

Pan, Y., Stevenson, R.J., Hill, B.H., Herlihy, A.T., and Collins, G.B., 1996, Using diatoms as indicators of ecological conditions in lotic systems-A regional assessment: Journal of the North American Benthological Society, v. 15 , no. 4, p. 481-495.

Patrick, R.A., and Reimer, C.W., 1966, The diatoms of the United States-Fragilariaceae, Eunotiaceae, Achnanthaceae, Naviculaceae: Monographs of the Academy of Natural Sciences of Philadelphia, no. 13, v. 1, 688 p.

1975, The diatoms of the United States-

Entomoneidaceae, Cymbellaceae, Gomphonemaceae, Epithemiaceae: Monographs of the Academy of Natural Sciences of Philadelphia, no. 13, v. 2, Part 1, 213 p.

Patton, C.J., and Truitt, E.P., 1992, Methods of analysis by the U.S. Geological Survey National Water Quality Laboratory-Determination of total phosphorus by a Kjeldahl digestion method that includes an automated finish that includes dialysis: U.S. Geological Survey Open-File Report 92-146, 39 p.

Paul, B.J., Duthie, and H.C., Taylor, W.D., 1991, Nutrient cycling by biofilms in running waters of different nutrient status: Journal of the North American Benthological Society, v. 10 , no. 1 , p. 31-41. 
Peruad, D., Jaagumagi, R., and Hayton, A., 1993, Guidelines for the protection and management of aquatic sediment quality in Ontario: Ontario Ministry of the Environment and Energy, [variously paged].

Peterson, B.J., Bahr, M., Jones, D., Repert, D., and Kling, G., 1993, Nitrogen flow in the Kuparuk River, Alaska: Bulletin of the North American Benthological Society, v. 10 , no. 1, p. 159.

Peterson, C.G., and Grimm, N.B., 1992, Temporal variation in enrichment effects during periphyton succession in a nitrogen-limited desert stream ecosystem: Journal of the North American Benthological Society v. 11, p. 20-36.

Platts, W.S., Armour, C., Booth, G.D., and others, 1987, Methods for evaluating riparian habitats with applications to management: U.S. Forest Service General Technical Report INT-221, p. 68-74.

Pogue, T.R., and Anderson, C.W., 1995, Processes controlling dissolved oxygen and $\mathrm{pH}$ in the Upper Willamette River Basin, Oregon, 1994: U.S. Geological Survey Water-Resources Investigations Report 95-4205, 71 p.

Porter, S.D., Cuffney, T.F., Gurtz, M.E., and Meador, M.R., 1993, Methods for collecting algal samples as part of the National Water-Quality Assessment Program: U.S. Geological Survey Open-File Report 93-409, 39 p.

Powell, M.A., 1995, Report on pH in the Jackson Creek and Little River drainage basins of the Umpqua National Forest: Roseburg, Oregon, U.S. Department of Agriculture, Forest Service, Umpqua National Forest, Draft report to the U.S. Forest Service, [variously paged].

1997, Water quality concerns in restoration of stream habitat in the Umpqua Basin, in Hall, J.D., Bisson, P.A., and Gresswell, eds., Searun cutthroat trout-Biology, management, and future conservation: Corvallis, Oregon Chapter, American Fisheries Society, p. 129-130.

Power, M.E., Stewart, A.J., and Matthews, W.J., 1988, Grazer control of algae in an Ozark mountain stream-Effects of short-term exclusion: Ecology, v. 69, no. 6, p. 1894-1898. 1990, Effects of fish in river food webs: Ecology, v. 250, p. 811-814.

1992a, Hydrologic and trophic controls of seasonal algal blooms in Northern California rivers: Archiv fur Hydrobiologia, v. 125, no. 4., p. 385-410.

1992b, Top-down and bottom-up forces in food websDo plants have primacy?: Ecology, v. 73, no. 3, p. 733746.

Rantz, S.E., and others, 1982, Measurement and computation of streamflow: U.S. Geological Survey Water-Supply Paper 2175, v. 1 and 2., 631 p.

Reimer, C.R., 1962, Environmental requirements of plankton algae and their effects on water quality_Diatoms and their physicochemical environment, in Fogg, G.E., Chairman, Biological problems in water pollution: Cincinnati, Ohio, Third Seminar, August 13-17, 1962, U.S. Department of Health, Education, and Welfare, Public Health Service, Publication No. 999-WP-25, p. 19-28.
Rinella, F.A., 1998, Major ion, nutrient, and trace-element concentrations in the Steamboat Creek Basin, Oregon, 1996: U.S. Geological Survey Open-File Report 98-4105, $31 \mathrm{p}$.

Rinella, J.F., 1979, Lakes of Oregon, Volume 6, Douglas County: U.S. Geological Survey Open-File Report, 124 p.

Rinella, J.F., 1986, Analysis of fixed-station water-quality in the Umpqua River Basin, Oregon, U.S. Geological Survey Water-Resources Investigations Report 85-4253, 96 p.

Robison, J.H., 1975, Availability and quality of ground water in the Sutherlin Area, Douglas County, Oregon:

U.S. Geological Survey Water-Resources Investigations Report 74-0032, 2 sheets, scale 1:62,500.

Rogers, L.J., and Gallon, J.R., 1988, Biochemistry of the algae and cyanobacteria: Clarendon Press, Oxford, 374 p.

Round, F.E., 1991, Diatoms in river water-monitoring studies: Journal of Applied Phycology, v. 3, p. 129-145.

Salinas, J.T., and Larson, D.W., 1995. Diamond LakeLimnological and bacterial investigations, 1992-1994: Roseburg, Oregon, U.S. Forest Service, Umpqua National Forest, Final Report, Umpqua National Forest, CAS9501, [variously paged].

Shacklette, H.T., and Boerngen, J.G., 1984, Element concentrations in soils and other surficial materials of the conterminous United States: U.S. Geological Survey Professional Paper 1270, 105 p.

Schoeman, F.R., 1973, A systematical and ecological study of the diatom flora of Lesotho with special reference to the water quality, Pretoria, South Africa, V\&R Printers, 355 p.

Schollett, M.A., Udovich, N.T., Tuchman, N.C., and Smarrelli, J., 1996, Organic nutrient preferences for benthic diatomsAn approach to understanding heterotrophic metabolism: Bulletin of the North American Benthological Society, v. 13 , no. 1, p. 245.

Shapiro, J., 1990, Current beliefs regarding dominance by blue-greens - The case for the importance of $\mathrm{CO} 2$ and $\mathrm{pH}$ : The International Association of Theoretical and Applied Limnology, v. 24, p. 38-54.

Shelton, L.R., 1994, Field guide for collecting and processing stream-water samples for the National Water-Quality Assessment Program: U.S. Geological Survey Open-File Report 94-455, $42 \mathrm{p}$.

Shelton, L.R., and Capel, P.D., 1994, Guidelines for collecting and processing samples of stream bed sediment for analysis of trace elements and organic contaminants for the National Water-Quality Assessment Program: U.S. Geological Survey Open-File Report 94-458, 20 p.

Steinman, A.D., 1996, Effects of grazers on freshwater benthic algae, in Stevenson, J.R., Bothwell, M.L., and Lowe, R.L., eds., Algal ecology_Freshwater benthic ecosystems: San Diego, California, Academic Press, Inc., p. 341-373.

Stevenson, R.J., 1997. Resource thresholds and stream ecosystem sustainability: Journal of the North American Benthological Society, v. 16, no. 2, p. 410-424. 
Stockner, J.G., and Shortreed, K.R.S., 1988, Response of Anabaena and Synechococcus to manipulation of nitrogen:phosphorus ratios in a lake fertilization experiment: Limnology and Oceanography, v. 33, p. 1348-1361.

Stumm, W., and Morgan, J.J., 1981, Aquatic Chemistry -An introduction emphasizing chemical equilibria in natural waters ( $2 \mathrm{~d}$ ed.): New York, John Wiley and Sons, 780 p.

Sullivan, K., Lisle, T.E., Dolloff, C.A., Grant, G.E., and Reid, L.M., 1987, Stream channels, the link between forests and fishes, in Salo, E.O., and Cundy, T.W., eds., Streamside management-Forestry and fishery interactions: University of Washington, Seattle, Contribution 57, College of Forest Resources, p. 39-97.

Tanner, D.Q., and Anderson, C.W., 1996, Assessment of water quality, nutrients, algal productivity, and management alternatives for low-flow conditions, South Umpqua River Basin, Oregon, 1990-92: U.S. Geological Survey Water-Resources Investigations Report 96-4082, 71 p.

Thornton, K.W., 1990a, Perspectives on reservoir limnology, in Thornton, K.W., Kimmel, B.L., and Payne, F.E., eds., Reservoir limnology: New York, John Wiley and Sons, Inc., p. 1-13.

1990b, Sedimentary processes, in Thornton, K.W., Kimmel, B.L., and Payne, F.E., eds., Reservoir limnology: New York, John Wiley and Sons, Inc., p. 43-69.

Tilman, D., Kiesling, R., Sterner, R., Kilham, S.S., and Johnson, F.A., 1986, Green, blue-green and diatom algaeTaxonomic differences in competitive ability for phosphorus, silicon and nitrogen: Archives of Hydrobiology, v. 106, no. 4, p. 473-485.

Triska, F.J., Duff, J.H., Avanzino, R.J.,1989, The role of water exchange between a stream channel and its hyporheic zone in nitrogen cycling at the terrestrial-aquatic interface: Hydrobiologia, v. 251, p. 167-184.

Triska, F.J., Kennedy, V.A., Avanzino, R.J., and Reilly, N.B., 1983, Effect of simulated canopy cover on regulation of nitrate uptake and primary production by natural periphyton communities, in Fontain, T.D., and Bartell, S.M., eds., Dynamics of lotic ecosystems: Ann Arbor, Michigan, Ann Arbor Science Publishers., p. 129-159.

Triska, F.J., Kennedy, V.A., Avanzino, R.J., Zellweger, G.W., and Bencala, K.E., 1989, Retention and transport of nutrients in a third order stream in northwestern California-Hyporheic processes: Ecology, v. 70, no. 6, p. 1893-1905.

Tuchman, N., 1996, The roll of heterotrophy in algae, in Stevenson, J.R., Bothwell, M.L., and Lowe, R.L., eds., Algal ecology, freshwater benthic ecosystems: San Diego, California, Academic Press, Inc., p. 299-319.

U.S. Environmental Protection Agency, 1996, Drinking water regulations and health advisories: Washington, D.C., U.S. Environmental Protection Agency Office of Water, EPA 822-B-96-002, 11 p.

U.S. Forest Service and Bureau of Land Management, 1994, Record of decision for amendments to Forest Service and Bureau of Land Management planning documents within the ranges of the Northern Spotted Owl: U.S. Forest
Service and Bureau of Land Management, April 1994,

$74 \mathrm{p}$.

1995, Little River watershed analysis, version 1.1:

Roseburg, Oregon, U.S. Forest Service, North Umpqua

Ranger District, [variously paged].

U.S. Geological Survey, 1915, Profile surveys in 1914 in Umpqua

River Basin, Oregon: U.S. Geological Survey

Water-Supply Paper 379, 7 p, 13 pls.

1994, Water resources data, Oregon, water year 1993:

U.S. Geological Survey Water-Data Report OR-93-1, $498 \mathrm{p}$.

1995, Water resources data, Oregon, water year 1994:

U.S. Geological Survey Water-Data Report OR-94-1, $473 \mathrm{p}$.

1996, Water resources data, Oregon, water year 1995:

U.S. Geological Survey Water-Data Report OR-95-1, $452 \mathrm{p}$.

1997, Water resources data, Oregon, water year 1996:

U.S. Geological Survey Water-Data Report OR-96-1, $432 \mathrm{p}$.

Vannote, R.L., Minshall, G.W., Cummins, K.W., Sedell, J.R., and Cushing, C.E., 1980, The river continuum concept: Journal of Canadian Fisheries and Aquatic Sciences, v. 37 , p. $130-137$.

Walton, S.P., Welch, E.P., And Horner, R.R., 1995, Stream periphyton response to grazing and changes in phosphorus concentration: Hydrobiologia, v. 302, p. 31-46.

Ward, A.K., Dahm, C.N., and Cummins, K.W., 1985, Nostoc (Cyanophyta) productivity in Oregon stream ecosystems - Invertebrate influences and differences between morphological types: Journal of Phycology, v. 21, p. 223-227.

Ward, J.V., and Stanford, J.A., 1983a, The serial discontinuity concept of lotic ecosystems, in Fontaine, T.D., and Bartell, S.M., eds., Dynamics of lotic ecosystems: Ann Arbor Science Publishers, p. 29-42.

1983b, The intermediate-disturbance hypothesis: an explanation for biotic diversity patterns in lotic ecosystems, in Fontaine, T.D., and Bartell, S.M., eds., Dynamics of Lotic Ecosystems: Ann Arbor Science Publishers, p. 347-356.

Welch, E.B., 1992, Ecological effects of wastewater-Applied limnology and pollutant effects, $2 \mathrm{~d}$ ed.; London, Chapman and Hall, $425 \mathrm{p}$.

Welch, E.B., Horner, R.R., Patmont, C.R., 1989, Prediction of nuisance periphytic biomass: A management approach: Water Resources, v. 23, no. 4, p. 401-405.

Welch, E.B., Jacoby, J.M., Horner, R.R., and Seeley, M.R., 1988, Nuisance biomass levels of periphytic algae in streams: Hydrobiologia, v. 157, p. 161-168.

Werner, S.L., Burkhardt, M.R., and DeRusseau, S.N., 1996, Methods of analysis by the U.S. Geological Survey National Water Quality Laboratory-Determination of pesticides in water by Carbopak-B solid-phase extraction and high-performance liquid chromatography: U.S. Geological Survey Open-File Report 96-216, 42 p.

Wetzel, R.G., 1983, Limnology, 2d ed.: Philadelphia, Saunders College Publishing. 858 p. 
Williams, D.M., and Round, F.E., 1987, Revision of the genus Fragilaria-Diatom Research, v. 2, no. 2, p. 267-288.

Wood, W.W., 1976, Guidelines for collection and field analysis of ground-water samples for selected unstable constituents: U.S. Geological Survey Techniques of Water-Resources Investigations, book 1, chapter D2, 24 p.

Wooton, J.T., Parker, M.S., and Power, M.E., 1996, Effects of disturbance on river food webs: Science, v. 273, p. 15581561.
Wooton, J.T., and Power, M.E., 1993, Productivity, consumers, and the structure of a river food chain: Proceedings of the National Academy of Sciences, v. 90, p. 1384-1387.

Zaugg, S.D., Sandstrom, M.W., Smith, S.G., and Fehlberg, K.M., 1995, Methods of analysis by the U.S. Geological Survey National Water-Quality Laboratory-Determination of pesticides in water by $\mathrm{C}-18$ solid-phase extraction and capillary-column gas chromatography/mass spectrometry with selected-ion monitoring: U.S. Geological Survey Open-File Report 95-181, 45 p. 
APPENDIXES 
Appendix A. Water-quality data from the July 1995 synoptic sampling in the North Umpqua River Basin, Oregon

Table A1. Water-quality data from samples collected by the U.S. Geological Survey in the North Umpqua River Basin, Oregon, July 24-29, 1995

[All concentrations reported are from filtered-water samples, except total Kjeldahl nitrogen (TKN) and total phosphorus (TP), which are from unfiltered and digested samples; total dissolved nitrogen (TDN) and total dissolved phosphorus (TDP) are also digested; $\mathrm{ft}^{3} / \mathrm{s}$, cubic feet per second; $\mu \mathrm{S} / \mathrm{cm}$, microsiemens per centimeter; $\mathrm{mg} / \mathrm{L}$, milligrams per liter; $\mu \mathrm{g} / \mathrm{L}$, micrograms per liter; SRP, soluble reactive phosphorus; -, not determined; R, River; E, estimated; <, less than]

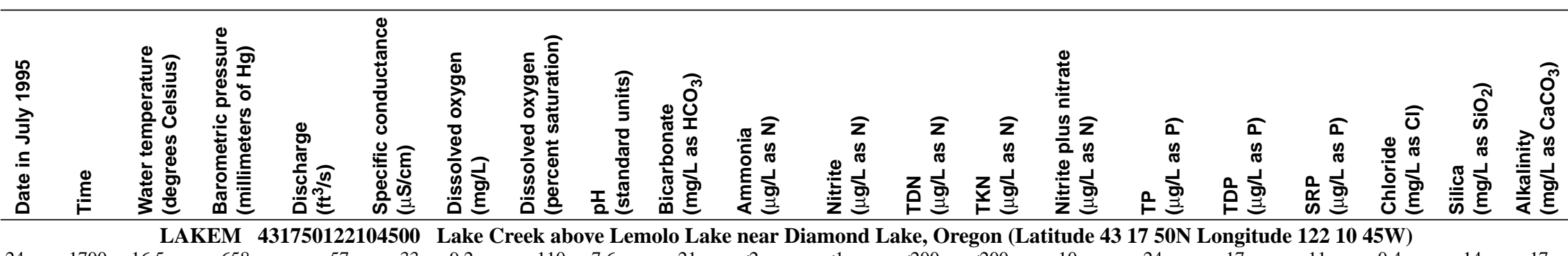

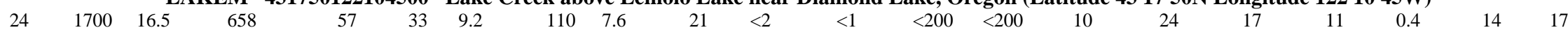

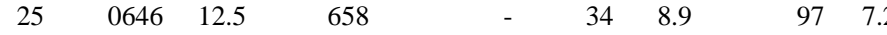

INLET 431839122091300 North Umpqua River above Lemolo Lake near Inlet Campground, Oregon (Latitude $431839 \mathrm{~N}$ Longitude $1220913 \mathrm{~W}$ )

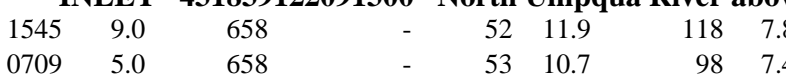

LEM1T 431924122111700 North Umpqua River below Lemolo Lake near Toketee Falls, Oregon (Latitude $431924 \mathrm{~N}$ Longitude 1221117 W)

$1755 \quad 9.0 \quad 658$

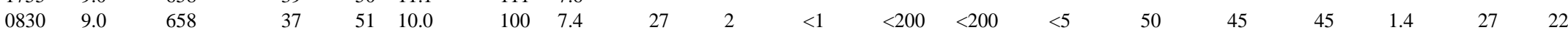

TOKET 431552122252100 North Umpqua River below Toketee Lake near Toketee Falls, Oregon (Latitude $431552 \mathrm{~N}$ Longitude 122 25 21 W)

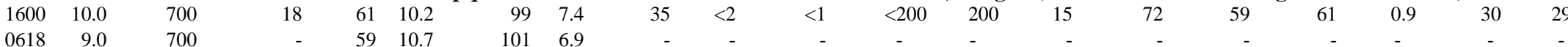

SODAT 431814122295100 North Umpqua River Below Soda Springs near Toketee Falls, Oregon (Latitude $431814 \mathrm{~N}$ Longitude 122 29 $51 \mathrm{~W}$ )

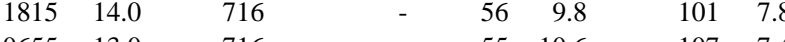

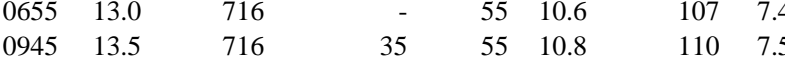

SEEPS 431813122295100 Seep At North Umpqua River below Soda Springs Dam near Toketee Falls, Oregon (Latitude $431813 N$ Longitude 122 29 51 W)

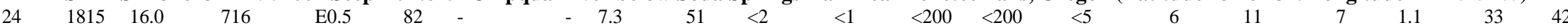

FISHP 431821122300100 Fish Pond Effluent at North Umpqua R below Soda Springs Dam near Toketee Falls, Oregon (Latitude $431821 \mathrm{~N}$ Longitude 1223001 W)

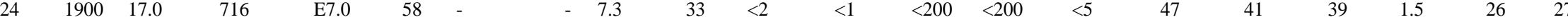

BSODA 431824122300600 North Umpqua River below Powerhouse at Soda Springs Dam near Toketee Falls, Oregon (Latitude $431824 N$ Longitude 1223006 W)

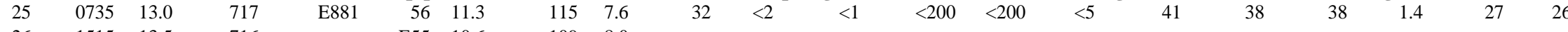

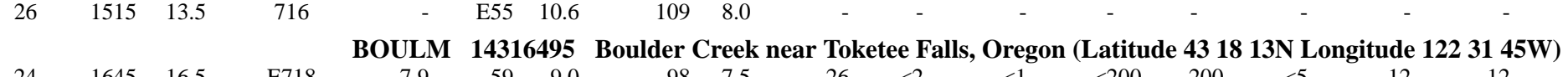

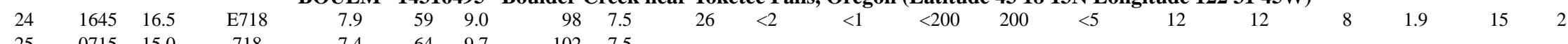


Appendix A. Water-quality data from the July 1995 synoptic sampling in the North Umpqua River Basin, Oregon-Continued

Table A1. Water-quality data from samples collected by the U.S. Geological Survey in the North Umpqua River Basin, Oregon, July 24-29, 1995-Continued [All concentrations reported are from filtered-water samples, except total Kjeldahl nitrogen (TKN) and total phosphorus (TP), which are from unfiltered and digested samples; total dissolved nitrogen (TDN) and total dissolved phosphorus (TDP) are also digested; $\mathrm{ft}^{3} / \mathrm{s}$, cubic feet per second; $\mu \mathrm{S} / \mathrm{cm}$, microsiemens per centimeter; $\mathrm{mg} / \mathrm{L}$, milligrams per liter; $\mu \mathrm{g} / \mathrm{L}$, micrograms per liter; SRP, soluble reactive phosphorus; -, not determined; R, River; E, estimated; <, less than]

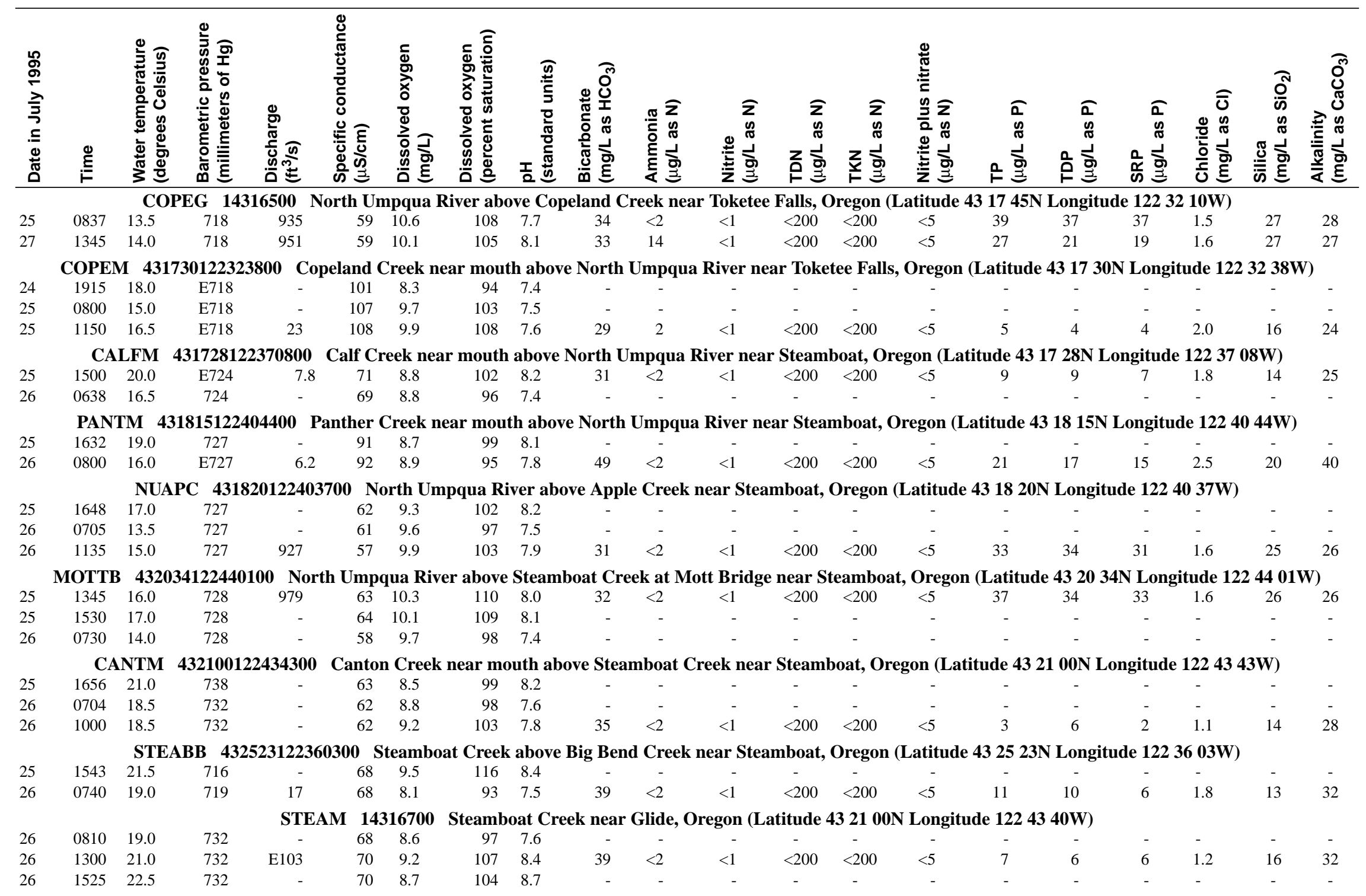


Table A1. Water-quality data from samples collected by the U.S. Geological Survey in the North Umpqua River Basin, Oregon, July 24-29, 1995-Continued [All concentrations reported are from filtered-water samples, except total Kjeldahl nitrogen (TKN) and total phosphorus (TP), which are from unfiltered and digested samples; total dissolved nitrogen (TDN) and total dissolved phosphorus (TDP) are also digested; $\mathrm{ft}^{3} / \mathrm{s}$, cubic feet per second; $\mu \mathrm{S} / \mathrm{cm}$, microsiemens per centimeter; mg/L, milligrams per liter; $\mu \mathrm{g} / \mathrm{L}$, micrograms per liter; $\mathrm{SRP}$, soluble reactive phosphorus; -, not determined; R, River; E, estimated; <, less than]

\begin{tabular}{|c|c|c|c|c|c|c|c|c|c|c|c|c|c|c|c|c|c|c|c|c|}
\hline 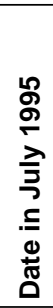 & $\stackrel{\mathscr{\Xi}}{\xi}$ & 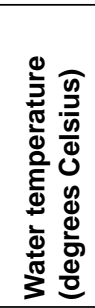 & 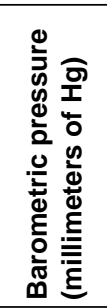 & 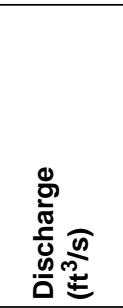 & 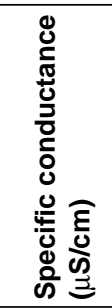 & 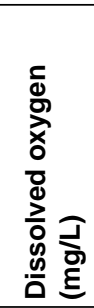 & 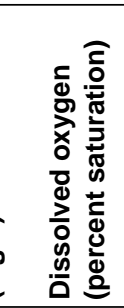 & 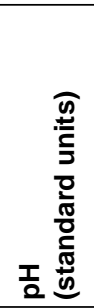 & 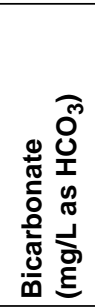 & 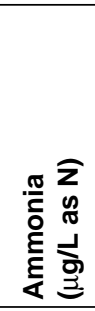 & 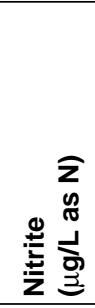 & 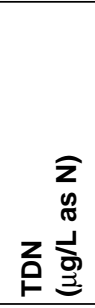 & 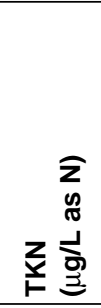 & 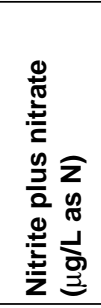 & 옹 & 옹 & 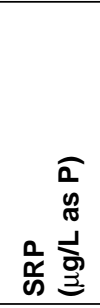 & 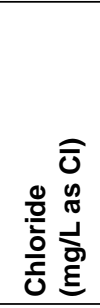 & ণิ & 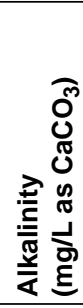 \\
\hline & USTM & 43203 & 1224425 & 00 Nort & th Umpq & ua Rive & er at rive & mile 5 & 2.5 belo & $v$ Steam & bat Cre & near $\mathrm{S}$ & teambo & t, Oreg & (Latitu & e 4320 & 4N Lon & gitude 1 & 224425 & (W) \\
\hline 26 & 0915 & 14.5 & 731 & - & 59 & 9.8 & 100 & 7.6 & 30 & $<2$ & $<1$ & $<200$ & $<200$ & $<5$ & 29 & 27 & 28 & 1.6 & 25 & 25 \\
\hline \multirow[t]{2}{*}{26} & 1750 & 18.0 & 731 & - & 59 & 9.2 & 102 & 8.1 & - & - & - & - & - & - & - & - & - & - & - & - \\
\hline & & & UBWC & 1431680 & Nortl & Umpq & qua Rive I & below & Steamb & at Cree & near Gl & le, Orę & yon (Lat & tude 43 & $18 \mathrm{~N}$ L & ngitude & 22483 & W) & & \\
\hline 26 & 1726 & 18.0 & 734 & 1,020 & 60 & 9.3 & 102 & 8.3 & - & - & - & - & - & - & - & - & - & - & - & - \\
\hline 27 & 0700 & 15.0 & 733 & 1,020 & 59 & 9.6 & 99 & 7.5 & - & - & - & - & - & - & - & - & - & - & - & - \\
\hline \multirow[t]{2}{*}{27} & 0830 & 15.0 & 733 & 1,020 & 59 & 9.6 & 99 & 7.5 & 32 & $<2$ & $<1$ & $<200$ & $<200$ & $<5$ & 32 & 27 & 28 & 1.6 & 25 & 27 \\
\hline & WRC & RM 4 & 1912122 & 482700 & Wright & Creek I & near mou & th abov & e Nortl & Umpqu & River $\mathbf{n}$ & ar Stear & nboat, & regon (1 & titude & $1912 \mathrm{~N}$ & Longitu & de 1224 & $827 W$ ) & \\
\hline 26 & 1750 & 16.5 & 734 & 1.4 & 70 & 9.3 & 99 & 7.6 & - & - & - & - & - & - & - & - & - & - & - & - \\
\hline \multirow[t]{2}{*}{27} & 0928 & 15.0 & 733 & - & 69 & 9.3 & 97 & 7.7 & - & - & - & - & - & - & - & - & - & - & - & - \\
\hline & & & & SUSN & JM 143 & 17100 & Susan C & reek ne & ar Idley & d Park, & regon ( & atitude & 43175 & N Longi & Ide 122 & 4 25W) & & & & \\
\hline 27 & 1450 & 18.0 & 742 & 2.3 & 68 & 9.1 & 99 & 7.6 & 42 & $<2$ & $<1$ & $<200$ & 200 & 39 & 23 & 25 & 24 & 0.9 & 20 & 34 \\
\hline \multirow[t]{2}{*}{27} & 1525 & 19.0 & 742 & - & 63 & 9.4 & 105 & 8.3 & - & - & - & - & - & - & - & - & - & - & - & - \\
\hline & & OCKM & 432000 & 12300070 & Rock & Creek & near mo & uth abo & ve Nort & Umpq & River I & ar Glid & le, Ore & n (Latit & de 4320 & $0 \mathrm{~N}$ Lon & situde 1 & 300 & $7 \mathrm{~W})$ & \\
\hline 26 & 1852 & 20.5 & 741 & - & 64 & 8.6 & 98 & 7.7 & - & - & - & - & - & - & - & - & - & - & - & - \\
\hline 27 & 0705 & 17.5 & 742 & - & 66 & 9.0 & 96 & 7.6 & - & - & - & - & - & - & - & - & - & - & - & - \\
\hline \multirow[t]{2}{*}{27} & 0915 & 17.5 & 743 & 80 & 66 & 9.1 & 97 & 7.5 & 34 & $<2$ & $<1$ & $<200$ & $<200$ & $<5$ & 39 & 34 & 36 & 1.3 & 19 & 28 \\
\hline & & & LTBL & K 43122 & 21122492 & $100 \mathrm{~L}$ & Little Rive & r above & Black & Creek n & Glide, & Oregon & (Latitud & 4312 & N Long & ude 122 & $1921 W$ ) & & & \\
\hline 26 & 1648 & 18.0 & 717 & 14 & 80 & 8.7 & 97 & 8.1 & - & - & - & - & - & - & - & - & - & - & - & - \\
\hline \multirow[t]{2}{*}{27} & 0724 & 15.5 & 717 & - & 79 & 9.5 & 102 & 7.9 & - & - & - & - & - & - & - & - & - & - & - & - \\
\hline & & & LTWI & F 4314 & 5312255 & 3400 I & Little Riv & er abov & e Wolf & reek ne & Glide, & regon & Latitud & 43145 & N Longi & ude 122 & $534 W)$ & & & \\
\hline 26 & 1545 & 21.0 & 732 & 30 & 88 & 8.7 & 102 & 8.6 & - & - & - & - & - & - & - & - & - & - & - & - \\
\hline \multirow[t]{2}{*}{27} & 0645 & 18.5 & 733 & - & 86 & 9.0 & 100 & 7.7 & - & - & - & - & - & - & - & - & - & - & - & - \\
\hline & & LITGL & 431750 & 12306000 & Little & River & near mol & th abo & ve Nort & Umpqt & River & ar Glid & e, Oregc & (Lati & 4317 & ON Lor & itude 12 & 30600 & & \\
\hline 26 & 1300 & 22.0 & 746 & 60 & 112 & 9.0 & 105 & 8.4 & 52 & $<2$ & $<1$ & $<200$ & $<200$ & $<5$ & 7 & 6 & 1 & 2.1 & 18 & 51 \\
\hline 26 & 1810 & 22.5 & 746 & - & 112 & 8.5 & 101 & 8.3 & - & - & - & - & - & - & - & - & - & - & - & - \\
\hline \multirow[t]{2}{*}{27} & 0634 & 20.0 & 745 & - & 112 & 8.3 & 94 & 7.6 & - & - & - & - & - & - & - & - & - & - & - & - \\
\hline & & & JGLD & 3182712 & 3072200 & North & h Umpqu & River & below I & ittle Riv & near $G$ & de, Ore & $\operatorname{gon}(\mathrm{La}$ & titude 4 & $827 \mathrm{~N}$ & ongitud & 12307 & $2 \mathrm{~W})$ & & \\
\hline 27 & 1440 & 20.5 & 742 & - & 63 & 10.1 & 115 & 8.3 & 34 & $<2$ & $<1$ & $<200$ & $<200$ & $<5$ & 28 & 23 & 22 & 1.7 & 23 & 28 \\
\hline 27 & 1745 & 21.0 & 745 & - & 64 & 9.8 & 113 & 8.5 & - & - & - & - & - & - & - & - & - & - & - & - \\
\hline
\end{tabular}


Appendix A. Water-quality data from the July 1995 synoptic sampling in the North Umpqua River Basin, Oregon-Continued

Table A2. Water-quality data at North Umpqua River above Rock Creek near Glide, Oregon (NURCR) in the North Umpqua River Basin, Oregon, July 24-29, 1995 [All concentrations reported are from filtered-water samples, except total Kjeldahl nitrogen (TKN) and total phosphorus (TP) which are from unfiltered and digested samples; total dissolved nitrogen (TDN) and total dissolved phosphorus (TDP) are also digested; $\mathrm{ft}^{3} / \mathrm{s}$, cubic feet per second; $\mu \mathrm{S} / \mathrm{cm}$, microsiemens per centimeter; mg/L, milligrams per liter; $\mu \mathrm{g} / \mathrm{L}$, micrograms per liter; $\mathrm{SRP}$, soluble reactive phosphorus; -, not determined; <, less than]

\begin{tabular}{|c|c|c|c|c|c|c|c|c|c|c|c|c|c|c|c|c|c|c|c|c|c|}
\hline 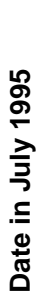 & $\stackrel{\oplus \underset{\xi}{\xi}}{\underline{\xi}}$ & 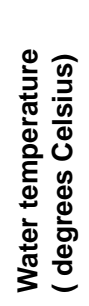 & 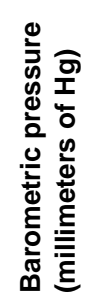 & 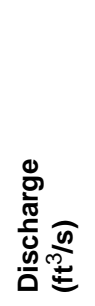 & 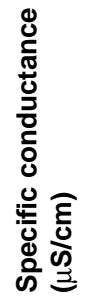 & 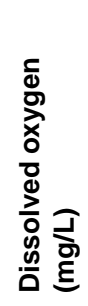 & 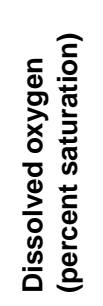 & 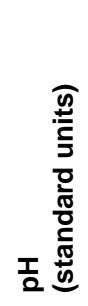 & 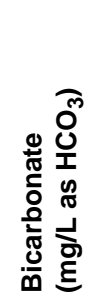 & 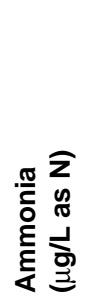 & 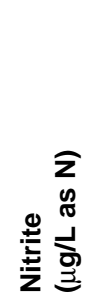 & 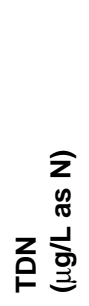 & z & 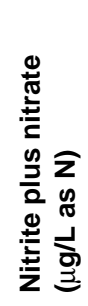 & م: & 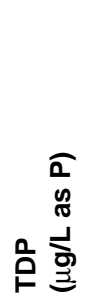 & 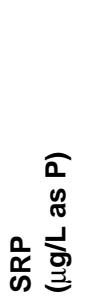 & 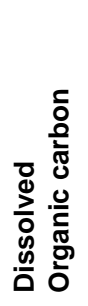 & 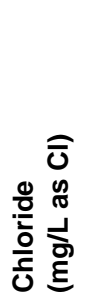 & 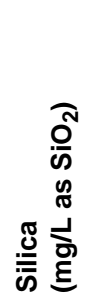 & 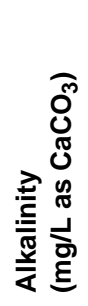 \\
\hline 26 & 1820 & 19.0 & 741 & - & 61 & 9.6 & 107 & 8.3 & - & - & - & - & - & - & - & - & - & - & - & - & - \\
\hline 27 & 0915 & 17.5 & 741 & 1,140 & 60 & 9.4 & 91 & 7.5 & 34 & $<2$ & $<1$ & $<200$ & $<200$ & $<5$ & 32 & 27 & 24 & 0.8 & 1.6 & 24 & 28 \\
\hline
\end{tabular}

\begin{tabular}{|c|c|c|c|c|c|c|c|c|c|c|c|c|c|c|c|c|c|c|}
\hline 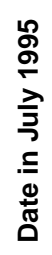 & $\stackrel{\mathscr{E}}{\xi}$ & 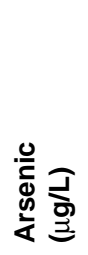 & 疍 & 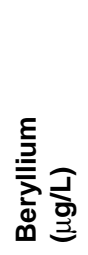 & 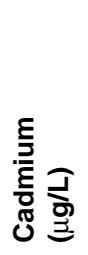 & 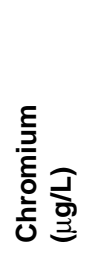 & 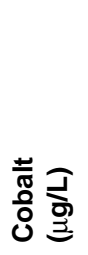 & 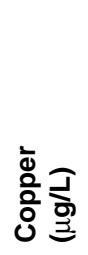 & ฐ & 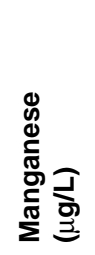 & 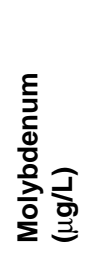 & $\begin{array}{l}\bar{\Phi} \\
\frac{\mathrm{d}}{\mathrm{L}} \overline{\mathrm{g}} \\
\end{array}$ & 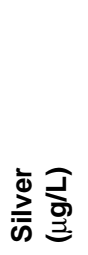 & 紊 & 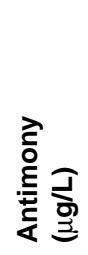 & 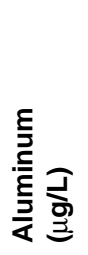 & 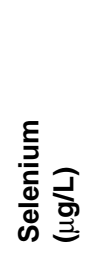 & 疍 \\
\hline 26 & 1820 & - & - & - & - & - & - & - & - & - & - & - & - & - & - & - & - & - \\
\hline 27 & 0915 & 1 & 3 & $<1$ & $<1$ & $<1$ & $<1$ & $<1$ & $<1$ & 1 & $<1$ & $<1$ & $<1$ & $<1$ & $<1$ & 9 & $<1$ & $<1$ \\
\hline
\end{tabular}


Appendix B. Quality assurance/quality control data for water collected between 1993 and 1995 in the North Umpqua River Basin, Oregon

Table B1. Quality-assurance data for nutrient samples collected by the U.S. Geological Survey in the North Umpqua River Basin, Oregon, 1993-95

[All concentrations reported are from filtered-water samples, except total Kjeldahl nitrogen (TKN) and total phosphorus (TP) which are from unfiltered and digested samples; total dissolved nitrogen (TDN) and total dissolved phosphorus (TDP) are also digested; SRP, soluble reactive phosphorus; mg/L, milligrams per liter; $\mu \mathrm{g} / \mathrm{L}$, micrograms per liter; -, not determined; <, less than]

\begin{tabular}{|c|c|c|c|c|c|c|c|c|c|c|c|c|}
\hline$\stackrel{\varrho}{\omega}$ & 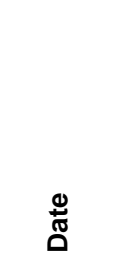 & $\stackrel{\mathscr{\Phi}}{\xi}$ & 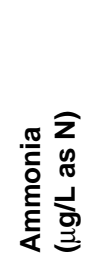 & 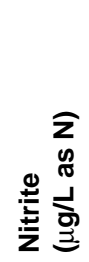 & 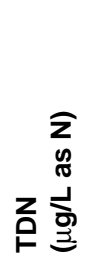 & z & 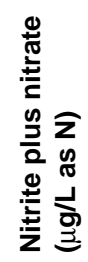 & 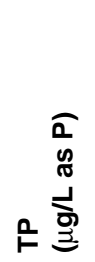 & 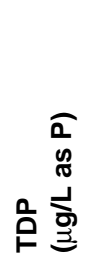 & 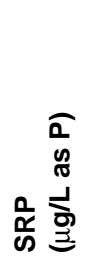 & 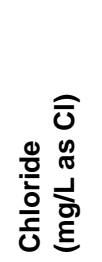 & 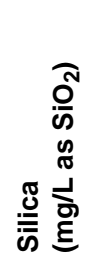 \\
\hline \multicolumn{13}{|c|}{ Blank samples } \\
\hline NUBWC & $07 / 27 / 95$ & 0700 & $<2$ & $<1$ & $<200$ & $<200$ & $<5$ & $<1$ & $<1$ & $<1$ & $<0.1$ & 0.4 \\
\hline ROCKM & $07 / 27 / 95$ & 0845 & $<2$ & $<1$ & $<200$ & $<200$ & $<5$ & $<1$ & $<1$ & $<1$ & $<.1$ & .5 \\
\hline NURCR & $07 / 06 / 94$ & 1658 & - & - & - & - & -- & - & - & - & .3 & .01 \\
\hline NURCR & $07 / 27 / 95$ & 0925 & $<2$ & $<1$ & $<200$ & $<200$ & $<5$ & 1 & $<1$ & $<1$ & $<.1$ & .2 \\
\hline \multicolumn{13}{|c|}{ Split sample } \\
\hline NURCR & 09/08/93 & 1354 & 30 & $<10$ & - & $<200$ & $<50$ & 40 & 50 & 28 & 1.8 & 25 \\
\hline NURCR & 09/08/93 & 1359 & 30 & $<10$ & - & $<200$ & $<50$ & 40 & 60 & 29 & - & - \\
\hline
\end{tabular}

Table B2. Quality-assurance data for trace-element samples collected by the U.S. Geological Survey in the North Umpqua River Basin, Oregon, 1993-95 [All concentrations reported are from filtered-water samples; $\mu \mathrm{g} / \mathrm{L}$, micrograms per liter]

\begin{tabular}{|c|c|c|c|c|c|c|c|c|c|c|c|c|c|c|c|c|c|c|c|}
\hline$\stackrel{ \pm}{\text { क }}$ & 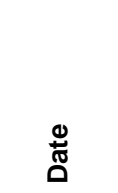 & $\stackrel{\oplus}{\underline{\xi}}$ & 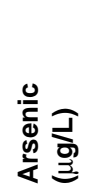 & 疍 & 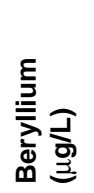 & 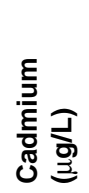 & 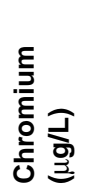 & 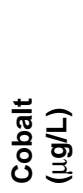 & 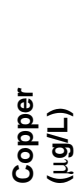 & ஓ్ ఫ & 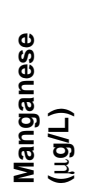 & 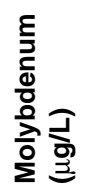 & 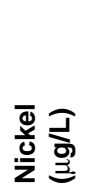 & 㐫 & 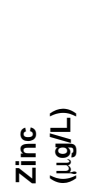 & 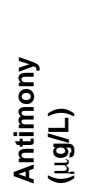 & 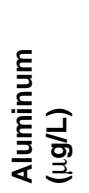 & 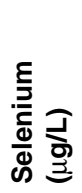 & 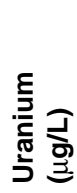 \\
\hline \multicolumn{20}{|c|}{ Blank samples } \\
\hline NUBWC & $09 / 07 / 93$ & 1408 & $<1$ & $<1$ & $<1$ & $<1$ & $<1$ & $<1$ & $<1$ & $<1$ & $<1$ & $<1$ & $<1$ & $<1$ & 4 & $<1$ & 2 & $<1$ & $<1$ \\
\hline NURCR & $09 / 08 / 93$ & 1402 & $<1$ & $<1$ & $<1$ & $<1$ & $<1$ & $<1$ & 1 & $<1$ & $<1$ & $<1$ & $<1$ & $<1$ & 3 & $<1$ & $<1$ & $<1$ & $<1$ \\
\hline NURCR & $12 / 09 / 93$ & 1238 & $<1$ & $<1$ & $<1$ & $<1$ & $<1$ & $<1$ & $<1$ & $<1$ & $<1$ & $<1$ & $<1$ & $<1$ & 3 & $<1$ & 2 & $<1$ & $<1$ \\
\hline NURCR & $07 / 06 / 94$ & 1658 & $<1$ & $<1$ & $<1$ & $<1$ & $<1$ & $<1$ & $<1$ & $<1$ & $<1$ & $<1$ & $<1$ & $<1$ & $<1$ & $<1$ & $<1$ & $<1$ & $<1$ \\
\hline NURCR & $07 / 27 / 95$ & 0925 & $<1$ & $<1$ & $<1$ & $<1$ & $<1$ & $<1$ & $<1$ & $<1$ & $<1$ & $<1$ & $<1$ & $<1$ & $<1$ & $<1$ & $<1$ & $<1$ & $<1$ \\
\hline \multicolumn{20}{|c|}{ Split sample } \\
\hline NURCR & $09 / 08 / 93$ & 1354 & 1 & 3 & $<1$ & $<1$ & $<1$ & $<1$ & $<1$ & $<1$ & 2 & $<1$ & $<1$ & $<1$ & $<1$ & $<1$ & 4 & $<1$ & $<1$ \\
\hline NURCR & 09/08/93 & 1359 & 1 & 4 & $<1$ & $<1$ & $<1$ & $<1$ & $<1$ & $<1$ & 1 & $<1$ & $<1$ & $<1$ & $<1$ & $<1$ & 3 & $<1$ & $<1$ \\
\hline
\end{tabular}


Appendix C. Water-quality and bed-sediment data from 1993-94 samplings in the North Umpqua River Basin, Oregon

Table C1. Analytical limits for constituents analyzed in North Umpqua River water at the National Water Quality Laboratory from 1993-96

[GC/MS, gas chromatography/mass spectroscopy; HPLC, high pressure liquid chromatography; MDL, method detection limit; MRL, minimum reporting limit; $\mu \mathrm{g} / \mathrm{L}$, micrograms per liter, or parts per billion; $\mathrm{mg} / \mathrm{L}$, milligrams per liter, or parts per million; (E), concentrations are estimates]

\begin{tabular}{|c|c|c|c|c|c|}
\hline Inorganic Compounds & MRL & Pesticides by GC/MS & $\begin{array}{c}\text { MDL } \\
(\mu \mathrm{g} / \mathrm{L})\end{array}$ & Pesticides by HPLC & $\begin{array}{c}\text { MDL } \\
(\mu \mathrm{g} / \mathrm{L})\end{array}$ \\
\hline \multicolumn{2}{|l|}{ Nutrients } & Acetochlor & 0.002 & Dicamba & 0.05 \\
\hline Total phosphorus, $\mu \mathrm{g} / \mathrm{L}$ as $\mathrm{P}(\mathrm{TP})$ & 1 & Alachlor & .002 & Bromoxynil & .05 \\
\hline Total dissolved phosphorus, $\mu \mathrm{g} / \mathrm{L}$ as $\mathrm{P}$ (TDP) & 1 & Metolachlor & .002 & Dichlobenil & .05 \\
\hline Soluble reactive phosphorus, $\mu \mathrm{g} / \mathrm{L}$ as $\mathrm{P}(\mathrm{SRP})$ & 1 & Napropamide & .003 & Aldicarb & .05 \\
\hline \multirow{2}{*}{$\begin{array}{l}\text { Total organic plus ammonia nitrogen, } \\
\mu \mathrm{g} / \mathrm{L} \text { as } \mathrm{N} \text { (TKN) }\end{array}$} & \multirow{2}{*}{200} & Pronamide & .003 & Aldicarb sulfone & .05 \\
\hline & & Propachlor & .007 & Aldicarb sulfoxide & .05 \\
\hline $\begin{array}{l}\text { Dissolved organic plus ammonia nitrogen, } \\
\mu \mathrm{g} / \mathrm{L} \text { as } \mathrm{N} \text { (TDN) }\end{array}$ & 200 & $\begin{array}{l}\text { Propanil } \\
\text { Carbaryl }\end{array}$ & $\begin{array}{r}.004 \\
\text { (E) } .003\end{array}$ & $\begin{array}{l}\text { 3-hydroxy-carbofuran } \\
\text { Methiocarb }\end{array}$ & $\begin{array}{l}.05 \\
.05\end{array}$ \\
\hline Ammonia nitrogen, $\mu \mathrm{g} / \mathrm{L}$ as $\mathrm{N}\left(\mathrm{NH}_{4}^{+}\right)$ & 2 & Carbofuran & (E) .003 & Methomyl & .05 \\
\hline Nitrite nitrogen, $\mu \mathrm{g} / \mathrm{L}$ as $\mathrm{N}\left(\mathrm{NO}_{2}{ }^{2-}\right)$ & 1 & Butylate & .002 & Oxamyl & .05 \\
\hline Nitrate plus nitrite nitrogen, $\mu \mathrm{g} / \mathrm{L}$ as $\mathrm{N}\left(\mathrm{NO}_{3}^{-}\right)$ & 5 & EPTC & .002 & Propham & .05 \\
\hline \multicolumn{2}{|l|}{ Trace Elements (dissolved) } & Molinate & .004 & Propoxur & .05 \\
\hline Aluminum, $\mu \mathrm{g} / \mathrm{L}$ as $\mathrm{Al}$ & 1 & Pebulate & .004 & Bentazon & .05 \\
\hline Antimony, $\mu \mathrm{g} / \mathrm{L}$ as $\mathrm{Sb}$ & 1 & Thiobencarb & .002 & 2,4-D & .05 \\
\hline Arsenic, $\mu \mathrm{g} / \mathrm{L}$ as As & 1 & Triallate & .001 & $2,4-\mathrm{DB}$ & .05 \\
\hline Barium, $\mu \mathrm{g} / \mathrm{L}$ as $\mathrm{Ba}$ & 1 & Benfluralin & .002 & Dacthal, mono-acid- & .05 \\
\hline Beryllium, $\mu \mathrm{g} / \mathrm{L}$ as $\mathrm{Be}$ & 1 & Ethalfluralin & .004 & Dichlorprop & .05 \\
\hline Cadmium, $\mu \mathrm{g} / \mathrm{L}$ as $\mathrm{Cd}$ & 1 & Pendimethalin & .004 & MCPA & .05 \\
\hline Chromium, $\mu \mathrm{g} / \mathrm{L}$ as $\mathrm{Cr}$ & 1 & Trifluralin & .002 & $\mathrm{MCPB}$ & .05 \\
\hline Cobalt, $\mu \mathrm{g} / \mathrm{L}$ as Co & 1 & 2,6-diethylaniline & .003 & Silvex & .05 \\
\hline Copper, $\mu \mathrm{g} / \mathrm{L}$ as $\mathrm{Cu}$ & 1 & Propargite & .013 & $2,4,5-\mathrm{T}$ & .05 \\
\hline Lead, $\mu \mathrm{g} / \mathrm{L}$ as $\mathrm{Pb}$ & 1 & DCPA & .002 & Oryzalin & .05 \\
\hline Manganese, $\mu \mathrm{g} / \mathrm{L}$ as $\mathrm{Mn}$ & 1 & Dieldrin & .001 & Dinoseb & .05 \\
\hline Mercury, $\mu \mathrm{g} / \mathrm{L}$ as $\mathrm{Hg}$ & .1 & $\mathrm{p}, \mathrm{p}$ '-DDE & .006 & Acifluorfen & .05 \\
\hline Molybdenum, $\mu \mathrm{g} / \mathrm{L}$ as Mo & 1 & alpha-HCH & .002 & 1-naphthol & .05 \\
\hline Nickel, $\mu \mathrm{g} / \mathrm{L}$ as $\mathrm{Ni}$ & 1 & Lindane & .004 & Chloramben & .05 \\
\hline Selenium, $\mu \mathrm{g} / \mathrm{L}$ as $\mathrm{Se}$ & 1 & Chlorpyrifos & .004 & Diuron & .05 \\
\hline Silver, $\mu \mathrm{g} / \mathrm{L}$ as $\mathrm{Ag}$ & 1 & Diazinon & .002 & Fenuron & .05 \\
\hline Uranium, $\mu \mathrm{g} / \mathrm{L}$ as $\mathrm{U}$ & 1 & Disulfoton & .017 & Fluometuron & .05 \\
\hline Zinc, $\mu \mathrm{g} / \mathrm{L}$ as $\mathrm{Zn}$ & 1 & Ethoprop & .003 & Neburon & .05 \\
\hline \multicolumn{2}{|l|}{ Major lons and Ancillary Analyses } & Fonofos & .003 & Chlorothalonil & .05 \\
\hline Bromide, $\mathrm{mg} / \mathrm{L}$ as $\mathrm{Br}$ & .01 & Malathion & .005 & Esfenvalerate & .05 \\
\hline Calcium, $\mathrm{mg} / \mathrm{L}$ as $\mathrm{Ca}$ & .02 & Azinphos-methyl & (E) .001 & Norflurazon & .05 \\
\hline Chloride, $\mathrm{mg} / \mathrm{L}$ as $\mathrm{Cl}$ & .1 & Methyl parathion & .006 & Clopyralid & .05 \\
\hline Fluoride, $\mathrm{mg} / \mathrm{L}$ as $\mathrm{F}$ & .1 & Parathion & .004 & Picloram & .05 \\
\hline Iron, $\mathrm{mg} / \mathrm{L}$ as $\mathrm{Fe}$ & 3 & Phorate & .002 & Triclopyr & .05 \\
\hline Potassium, $\mathrm{mg} / \mathrm{L}$ as $\mathrm{K}$ & .1 & Terbufos & .013 & Bromacil & .05 \\
\hline Silica, $\mathrm{mg} / \mathrm{L}$ as $\mathrm{SiO}_{2}$ & .01 & cis-Permethrin & .005 & & \\
\hline Sodium, $\mathrm{mg} / \mathrm{L}$ as $\mathrm{Na}$ & .2 & Linuron & .002 & & \\
\hline Sulfate, $\mathrm{mg} / \mathrm{L}$ as $\mathrm{SO}_{4}{ }^{3-}$ & .1 & Tebuthiuron & .01 & & \\
\hline Alkalinity, $\mathrm{mg} / \mathrm{L}$ as $\mathrm{CaCO}_{3}$ & 1 & Atrazine & .001 & & \\
\hline Total dissolved solids, $\mathrm{mg} / \mathrm{L}$ & 1 & Cyanazine & .004 & & \\
\hline Hardness, $\mathrm{mg} / \mathrm{L}$ as $\mathrm{CaCO}_{3}$ & 1 & Desethylatrazine & (E) .002 & & \\
\hline Dissolved organic carbon, $\mathrm{mg} / \mathrm{L}$ as $\mathrm{C}$ & .1 & Metribuzin & .004 & & \\
\hline \multirow[t]{3}{*}{ Suspended organic carbon, $\mathrm{mg} / \mathrm{L}$ as $\mathrm{C}$} & .1 & Prometon & .018 & & \\
\hline & & Simazine & .005 & & \\
\hline & & Terbacil & (E) .007 & & \\
\hline
\end{tabular}


Appendix C. Water-quality and bed-sediment data from 1993-94 samplings in the North Umpqua River Basin, Oregon-Continued

Table C2. Analytical limits for constituents analyzed in North Umpqua River streambed sediment at the National Water Quality Laboratory from 1993-96

[MRL, minimum reporting limit; LLD, lower limit of detections; PCB, polychlorinated biphenyl; PCN, polychlorinated napthalene; $\mu \mathrm{g} / \mathrm{L}$; dry wt, dry weight; (E), concentrations are estimates]

\begin{tabular}{lc|lc}
\hline & $\begin{array}{c}\text { MRL } \\
\text { (dry weight) }\end{array}$ & \multicolumn{1}{c}{ MRL } \\
\multicolumn{1}{c}{ Trace Elements } & & \multicolumn{1}{c}{ Trace Elements-Continued } \\
(dry weight)
\end{tabular}


Appendix C. Water-quality and bed-sediment data from 1993-94 samplings in the North Umpqua River Basin Oregon-Continued

Table C3. Nutrient, major ion, and miscellaneous field parameters collected by the U.S. Geological Survey in the North Umpqua River Basin, Oregon,1993-94

[All concentrations reported are from filtered-water samples, except suspended sediment, total Kjeldahl nitrogen (TKN) and total phosphorus (TP) which are from unfiltered and digested samples, and suspended organic carbon which is from unfiltered water; total dissolved nitrogen (TDN) and total dissolved phosphorus (TDP) are also digested; $\mathrm{ft}^{3} / \mathrm{s}$, cubic feet per second; $\mu \mathrm{S} / \mathrm{cm}$, microsiemens per centimeter; $\mathrm{mg} / \mathrm{L}$, milligrams per liter; $\mu \mathrm{g} / \mathrm{L}$, micrograms per liter; SRP, soluble reactive phosphorus; $\mathrm{mg} / \mathrm{m}^{2}$, milligrams per square meter; -, not determined; <, less than; E, estimated]

\begin{tabular}{|c|c|c|c|c|c|c|c|c|c|c|c|c|c|c|c|c|c|c|c|}
\hline$\stackrel{\oplus}{\infty}$ & $\frac{0}{\pi}$ & $\stackrel{\stackrel{\otimes}{\xi}}{=}$ & 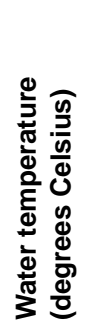 & 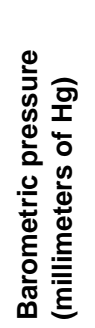 & 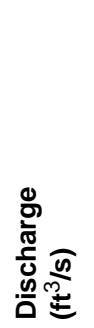 & 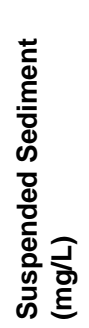 & 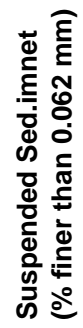 & 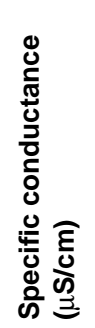 & 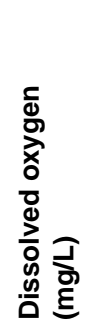 & 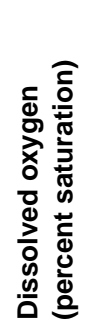 & 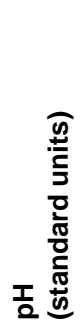 & 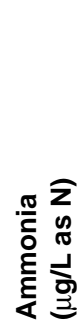 & 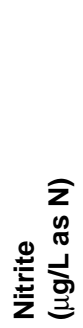 & 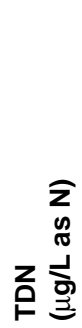 & 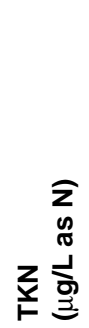 & 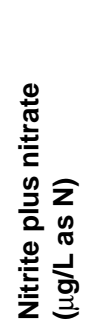 & 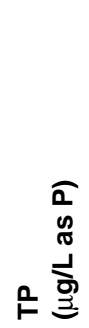 & 옹 & 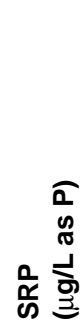 \\
\hline NUBWC & $09 / 07 / 93$ & 1430 & 15.0 & 738 & 857 & 4 & 57 & 67 & 9.7 & 99 & 8.2 & 10 & $<10$ & - & $<200$ & $<<50$ & 50 & 50 & 30 \\
\hline NUBWC & $12 / 08 / 93$ & 1220 & 6.5 & 724 & 5750 & - & - & 41 & 11.9 & 102 & 7.5 & 15 & 1 & $<200$ & $<200$ & $<15$ & 51 & 29 & 21 \\
\hline NURCR & 09/08/93 & 1354 & 16.5 & 743 & 857 & 2 & 57 & 66 & 9.9 & 104 & 7.9 & 30 & $<10$ & - & $<200$ & $<50$ & 40 & 50 & 28 \\
\hline NURCR & $12 / 09 / 93$ & 1230 & 6.5 & 724 & 3660 & - & - & 42 & 12.2 & 104 & 7.5 & 12 & 1 & $<200$ & $<200$ & $<17$ & 41 & 29 & 20 \\
\hline NURCR & 07/06/94 & 1650 & 17.5 & 738 & E 804 & 3 & - & 64 & 10.0 & 108 & 8.2 & 8 & $<1$ & $<200$ & $<200$ & $<5$ & 44 & 37 & 36 \\
\hline NURCR & 07/07/94 & 1725 & 20.0 & 738 & - & - & - & 65 & 9.5 & 107 & 8.5 & - & - & - & - & - & - & - & - \\
\hline NURCR & 07/08/94 & 0740 & 17.5 & 738 & - & - & - & 64 & 8.9 & 96 & 7.3 & - & - & - & - & - & - & - & - \\
\hline NURCR & 09/13/94 & 1545 & 14.0 & 741 & 601 & 3 & 83 & 65 & 10.6 & 106 & 8.1 & 2 & 1 & $<200$ & $<200$ & $<5$ & 40 & 35 & 34 \\
\hline NURCR & $09 / 14 / 94$ & 0740 & 12.5 & 741 & - & - & - & 69 & 10.0 & 96 & 7.5 & - & - & - & - & - & - & - & - \\
\hline
\end{tabular}

\begin{tabular}{|c|c|c|c|c|c|c|c|c|c|c|c|c|c|c|c|c|c|c|}
\hline$\stackrel{\Xi}{\oplus}$ & $\stackrel{0}{\frac{\pi}{\pi}}$ & 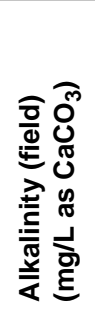 & 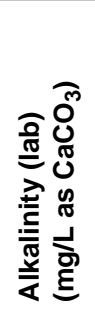 & 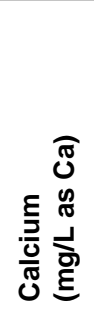 & 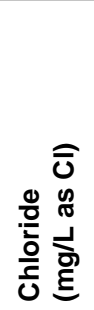 & 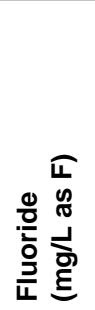 & 홍 & 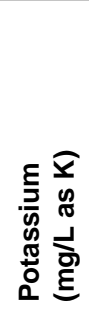 & 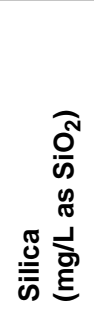 & 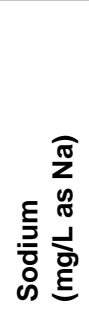 & 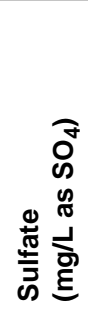 & 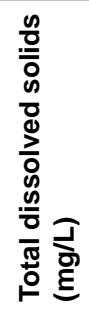 & 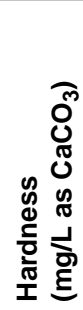 & 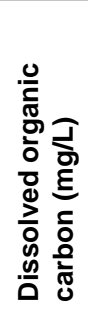 & 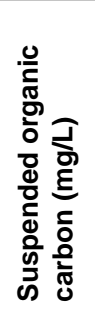 & 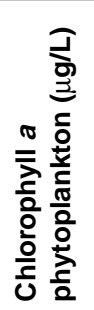 & 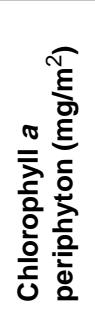 & 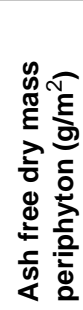 \\
\hline NUBWC & $09 / 07 / 93$ & 29 & 30 & 5.5 & 1.8 & $<0.1$ & 10 & 0.97 & 25 & 4.8 & 1.5 & 62 & 22 & 0.7 & 0.3 & - & - & - \\
\hline NUBWC & $12 / 08 / 93$ & - & 19 & 4.5 & 1.3 & .1 & 100 & .40 & 15 & 2.8 & 1.7 & 44 & 17 & 3.4 & .6 & - & - & - \\
\hline NURCR & 09/08/93 & 30 & 30 & 5.4 & 1.8 & .1 & 10 & 1.0 & 25 & 4.7 & 1.5 & 60 & 21 & .9 & .3 & - & - & - \\
\hline NURCR & $12 / 09 / 93$ & - & 20 & 4.5 & 1.2 & .2 & 87 & .40 & 15 & 2.8 & 1.6 & 48 & 17 & 3.8 & .8 & - & - & - \\
\hline NURCR & 07/06/94 & - & 31 & 5.2 & 1.8 & $<.1$ & 22 & .90 & 23 & 4.4 & 1.6 & 56 & 20 & .6 & .5 & 0.9 & 246.4 & - \\
\hline NURCR & 07/07/94 & - & - & - & - & - & - & - & - & - & - & - & - & - & - & - & - & - \\
\hline NURCR & 07/08/94 & - & - & - & - & - & - & - & - & - & - & - & - & - & - & - & - & - \\
\hline NURCR & 09/13/94 & - & 32 & 5.5 & 2.4 & $<.1$ & 24 & 1.1 & 25 & 5.4 & 1.4 & 39 & 22 & 0.9 & - & 1.0 & 34.4 & 121.6 \\
\hline NURCR & 09/14/94 & - & & - & - & - & - & - & - & - & - & - & - & - & - & - & - & - \\
\hline
\end{tabular}


Appendix C. Water-quality and bed-sediment data from 1993-94 samplings in the North Umpqua River Basin, Oregon-Continued

Table C4. Trace-element data from filtered-water samples collected by the U.S. Geological Survey in the North Umpqua River Basin, Oregon, 1993-94

$[\mu \mathrm{g} / \mathrm{L}$, micrograms per liter; -, not determined; <, less than]

\begin{tabular}{|c|c|c|c|c|c|c|c|c|c|c|c|c|c|c|c|c|c|c|c|c|}
\hline$\stackrel{\Xi}{\omega}$ & $\stackrel{0}{\frac{\pi}{\pi}}$ & 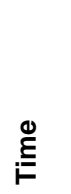 & 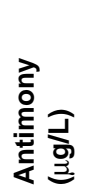 & 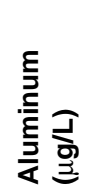 & 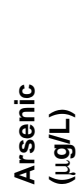 & 晃 & 疍 & 疍 & 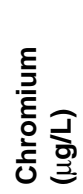 & 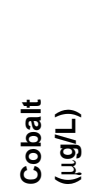 & 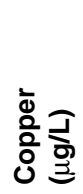 & ฐ & 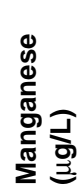 & 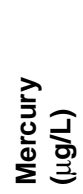 & 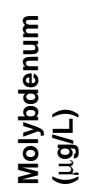 & 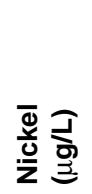 & 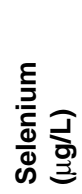 & ฏ & 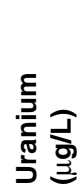 & 方 \\
\hline NUBWC & $09 / 07 / 93$ & 1430 & $<1$ & 5 & 1 & 3 & $<1$ & $<1$ & $<1$ & $<1$ & $<1$ & $<1$ & $<1$ & $<0.1$ & $<1$ & $<1$ & $<1$ & $<1$ & $<1$ & 3 \\
\hline NUBWC & $12 / 08 / 93$ & 1220 & $<1$ & 153 & $<1$ & 4 & $<1$ & $<1$ & $<1$ & $<1$ & 2 & $<1$ & 2 & $<.1$ & $<1$ & 1 & $<1$ & $<1$ & $<1$ & 7 \\
\hline NURCR & 09/08/93 & 1354 & $<1$ & 4 & 1 & 3 & $<1$ & $<1$ & $<1$ & $<1$ & $<1$ & $<1$ & 2 & $<.1$ & $<1$ & $<1$ & $<1$ & $<1$ & $<1$ & $<1$ \\
\hline NURCR & $12 / 09 / 93$ & 1230 & $<1$ & 167 & $<1$ & 5 & $<1$ & $<1$ & $<1$ & $<1$ & 2 & $<1$ & 2 & $<.1$ & $<1$ & 1 & $<1$ & $<1$ & $<1$ & $<1$ \\
\hline NURCR & 07/07/94 & 1725 & - & - & - & - & - & - & - & - & - & - & - & - & - & - & - & - & - & - \\
\hline NURCR & 07/08/94 & 0740 & - & - & - & - & - & - & - & - & - & - & - & - & - & - & - & - & - & - \\
\hline NURCR & 09/13/94 & 1545 & - & - & - & - & - & - & - & - & - & - & 2 & - & - & - & - & - & - & - \\
\hline NURCR & 09/14/94 & 0740 & - & - & - & - & - & - & - & - & - & - & - & - & - & - & - & - & - & - \\
\hline
\end{tabular}


Appendix C. Water-quality and bed-sediment data from 1993-94 samplings in the North Umpqua River Basin,

Oregon-Continued

Table C5. Organic-pesticide data from filtered-water samples collected by the U.S. Geological Survey in the North Umpqua River Basin, Oregon, December 8-9,1993

$[\mu \mathrm{g} / \mathrm{L}$, micrograms per liter; $<$, less than]

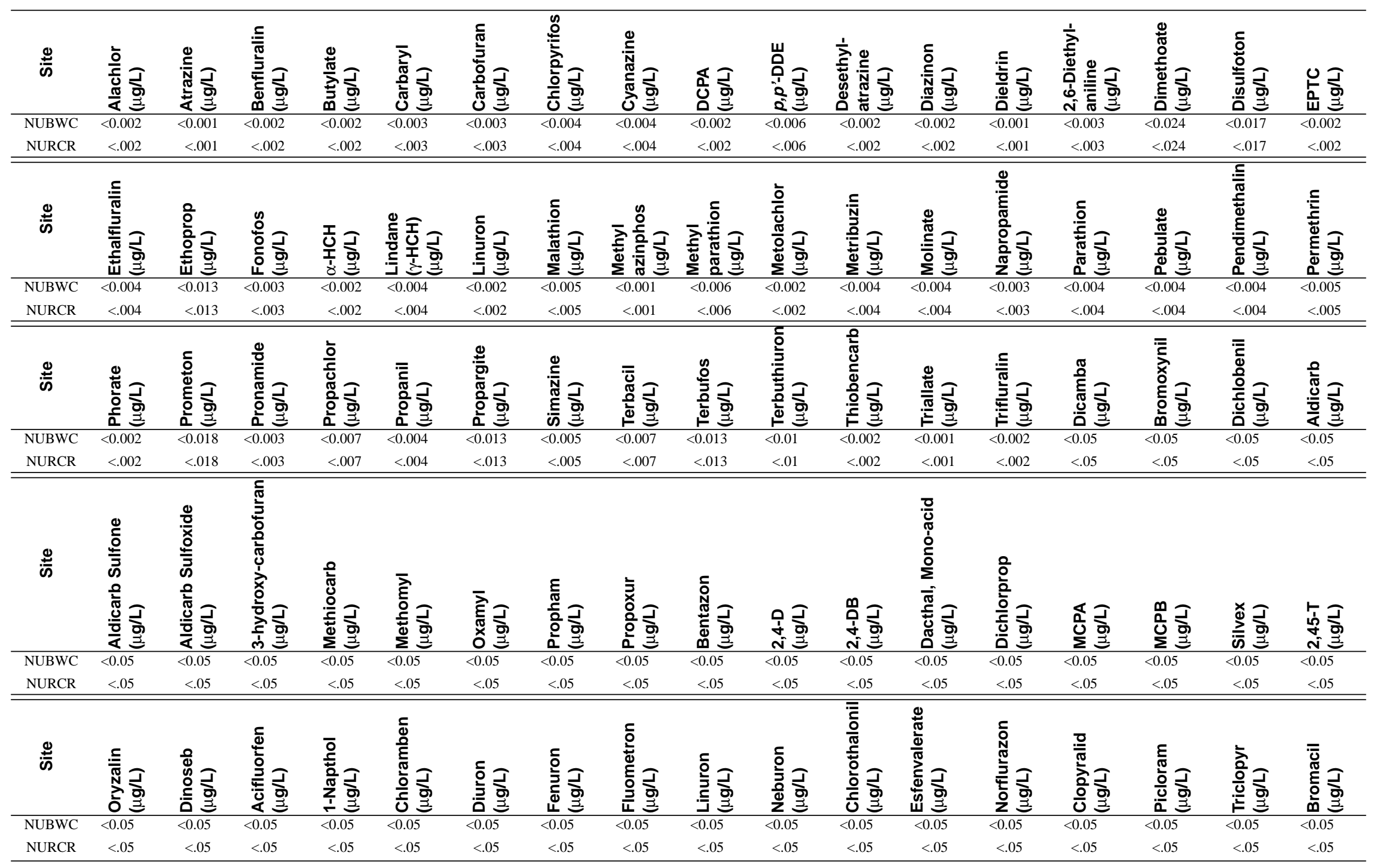


Appendix C. Water-quality and bed-sediment data from 1993-94 samplings in the North Umpqua River Basin, Oregon-Continued

Table C6. Trace-element and organochlorine data from bed-sediment samples collected by the U.S. Geological Survey in the North Umpqua River Basin, Oregon, 1993

$[<$, less than; $\mu \mathrm{g} / \mathrm{kg}$, micrograms per kilogram; ( $\mu \mathrm{g} / \mathrm{g}$, micrograms per gram; mm, millimeter; org., organic; -, not determined]

\begin{tabular}{|c|c|c|c|c|c|c|c|c|c|c|c|c|c|c|c|c|c|c|}
\hline$\stackrel{\oplus}{\dot{\omega}}$ & $\frac{0}{\pi}$ & $\stackrel{\varrho}{\Xi}$ & 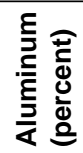 & 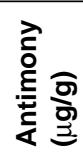 & 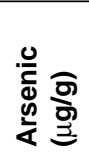 & 롤 음 & 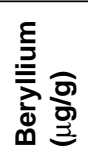 & 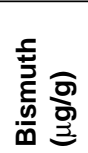 & 톨 & 통 & 롱 응 & 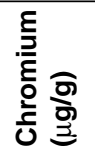 & 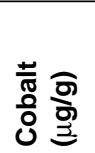 & 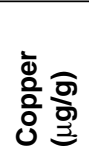 & 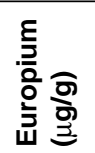 & 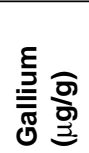 & 흥 응 응 & 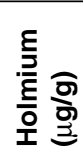 \\
\hline NUBWC & $09 / 07 / 93$ & 1730 & 5.6 & 0.4 & 9.4 & 310 & $<1$ & $<10$ & 0.2 & 1.9 & 30 & 69 & 16 & 24 & $<2$ & 12 & $<8$ & $<4$ \\
\hline NURCR & 09/08/93 & 1100 & 5.1 & .4 & 7.8 & 270 & $<1$ & $<10$ & .3 & 1.6 & 31 & 54 & 14 & 23 & $<2$ & 12 & $<8$ & $<4$ \\
\hline NURCR & 09/08/93 & 1105 & 5.2 & .6 & 7.4 & 270 & $<1$ & $<10$ & .3 & 1.6 & 30 & 54 & 14 & 23 & $<2$ & 11 & $<8$ & $<4$ \\
\hline
\end{tabular}

\begin{tabular}{|c|c|c|c|c|c|c|c|c|c|c|c|c|c|c|c|c|c|c|}
\hline$\stackrel{ \pm}{\omega}$ & $\stackrel{\Xi}{\Xi}$ & 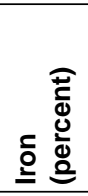 & 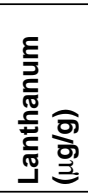 & 。 & 疍 & 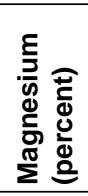 & 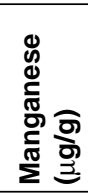 & 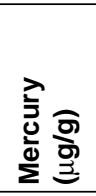 & 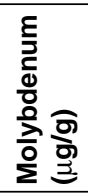 & 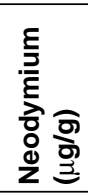 & 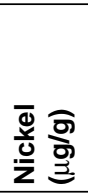 & 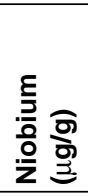 & 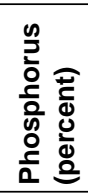 & 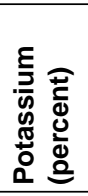 & 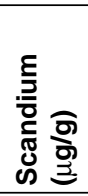 & 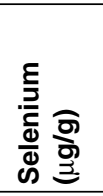 & 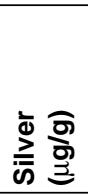 & 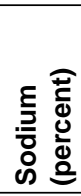 \\
\hline NUBWC & $09 / 07 / 93$ & 3.7 & 14 & 10 & 20 & 1 & 930 & $<0.02$ & $<<2$ & 15 & 28 & 7 & 0.17 & 0.54 & 14 & $\begin{array}{ll}0.4 \\
\end{array}$ & 0.1 & 1 \\
\hline NURCR & 09/08/93 & 3.2 & 14 & 10 & 20 & .88 & 740 & $<.02$ & $<2$ & 16 & 21 & 6 & .15 & .48 & 14 & .4 & .1 & .86 \\
\hline NURCR & 09/08/93 & 3.3 & 15 & 9 & 20 & .88 & 740 & $<.02$ & $<2$ & 16 & 21 & 7 & .15 & .49 & 14 & .3 & .2 & .85 \\
\hline
\end{tabular}
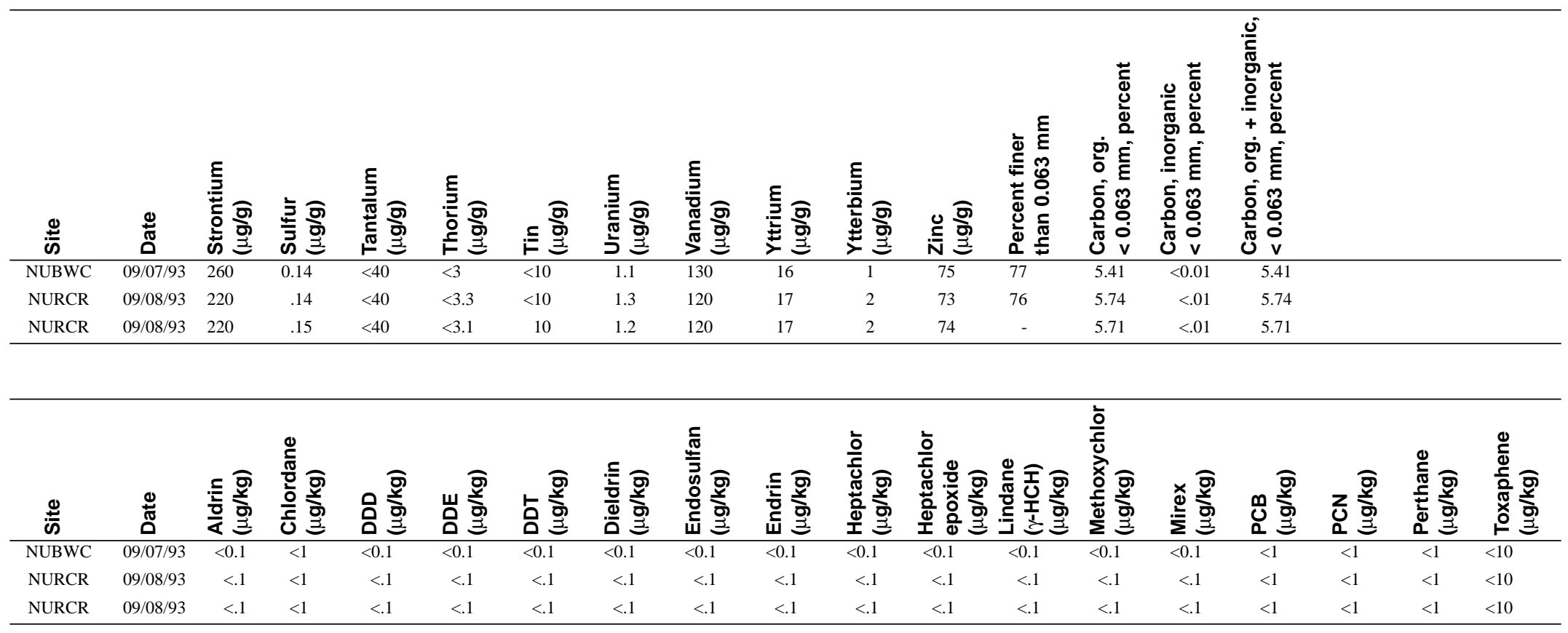
Appendix D. Nutrient concentrations from sites in the North Umpqua River Basin, Oregon, sampled by PacifiCorp during July 1995

Table D1. Water-quality data collected by PacifiCorp in the North Umpqua River Basin, Oregon, July 1995

[All concentrations reported are from filtered-water samples, except total Kjeldahl nitrogen (TKN) and total phosphorus (TP), which are from unfiltered and digested samples; $\mu \mathrm{g} / \mathrm{L}$, micrograms per liter; $\mathrm{mg} / \mathrm{L}$, milligrams per liter; <, less than]

\begin{tabular}{|c|c|c|c|c|c|c|c|c|c|c|c|}
\hline$\stackrel{\Xi}{\dot{5}}$ & 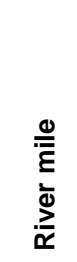 & 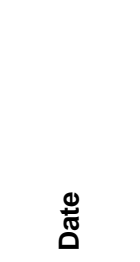 & 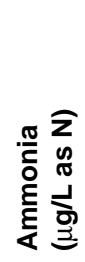 & 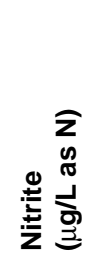 & 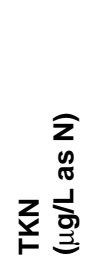 & 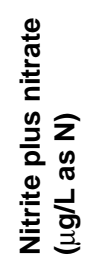 & 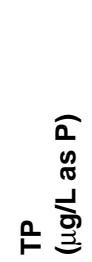 & 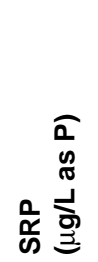 & 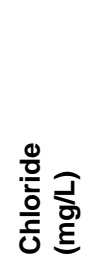 & 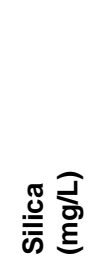 & 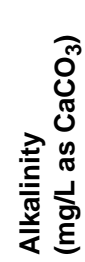 \\
\hline LEM1T & 92.9 & $07 / 25 / 95$ & $<1$ & $<5$ & 200 & 10 & 70 & 38 & 1.3 & 32.7 & 25.5 \\
\hline LEM2B & 77.3 & $07 / 25 / 95$ & $<1$ & $<5$ & 1,600 & $<10$ & 40 & 32 & 4.9 & 24.1 & 33.9 \\
\hline LEM2FF & 77.1 & $07 / 25 / 95$ & $<1$ & $<5$ & $<200$ & $<10$ & 50 & 27 & 1.1 & 23.3 & 25.8 \\
\hline CLRAS & 86.5 & $07 / 25 / 95$ & 1 & $<5$ & $<200$ & 10 & 100 & 70 & 1.0 & 38.0 & 31.0 \\
\hline CLR2B & 75.4 & $07 / 25 / 95$ & $<1$ & $<5$ & $<200$ & $<10$ & 80 & 55 & .7 & 35.5 & 30.7 \\
\hline FISHA & 78.4 & $07 / 25 / 95$ & $<1$ & $<5$ & 380 & $<10$ & 30 & 17 & .3 & 19.2 & 26.5 \\
\hline FISHB & 71.8 & $07 / 25 / 95$ & $<1$ & $<5$ & $<200$ & $<10$ & 40 & 15 & .3 & 22.7 & 26.8 \\
\hline
\end{tabular}


Appendix E. Algal data from 1994-95 samplings in the North Umpqua River Basin, Oregon

Table E1. Benthic chlorophyll $a$ and biomass from 10 sites in the North Umpqua River Basin,

Oregon, July 24-29, 1995

[Refer to table 4 for list of site acronyms with station identification numbers and river miles. Solar availability

is measured with a solar pathfinder and represents the percent of average solar radiation expected during a

given month, with a southern exposure. AFDM, ash-free dry-mass; $\mu \mathrm{g} / \mathrm{L}$, micrograms per liter; $\mathrm{mg} / \mathrm{m}^{2}$;

milligrams per meter squared; $\mathrm{g} / \mathrm{m}^{2}$, grams per square meter; -, not determined]

\begin{tabular}{lcccc}
\hline $\begin{array}{c}\text { Site } \\
\text { acronym }\end{array}$ & $\begin{array}{c}\text { Phytoplankton } \\
\text { chlorophyll } \mathbf{a} \\
(\boldsymbol{\mu} \mathbf{g} / \mathbf{L})\end{array}$ & $\begin{array}{c}\text { Periphyton } \\
\text { chlorophyll } \mathbf{a} \\
\left(\mathbf{m g} / \mathbf{m}^{\mathbf{2}}\right)\end{array}$ & $\begin{array}{c}\text { AFDM } \\
\left(\mathbf{g} / \mathbf{m}^{\mathbf{2}}\right)\end{array}$ & $\begin{array}{c}\text { Solar availability } \\
\text { (percent) }\end{array}$ \\
\hline INLET & - & 82 & 16 & 97 \\
LAKEM & 2.1 & 11 & 4 & 58 \\
LEM1T & 1.5 & 120 & 41 & 39 \\
TOKET & - & 132 & 50 & 96 \\
BSODA & .4 & 209 & 68 & 65 \\
COPEG & .5 & 27 & 2 & 72 \\
STEABB & - & 33 & 14 & 73 \\
STEAM & .2 & 39 & 5 & 93 \\
NUSTM & - & 50 & 7 & 95 \\
NURCR & .5 & 58 & 8 & \\
\hline
\end{tabular}

Table E2. Biovolumes of algal taxa collected from 10 sites in the North Umpqua River Basin, Oregon, 1994-95

[Refer to table 4 for list of site acronyms with station identification numbers and river miles. Taxon biovolumes are given in 1,000 cubic micrometers/square centimeter. Replicate QA samples, Rep 1 and Rep 2, were collected only at NURCR. Some taxa are assigned to autecological guilds as follows: NF, nitrogen fixers, NH; facultative nitrogen heterotrophs; E, eutrophic taxa; O, oligotrophic taxa; A, alkaliphilic taxa; C, cold-water taxa. Sources for autecological classifications are from Patrick and Reimer, 1966, 1975; Schoeman, 1973; Lowe, 1974; Dam and others, 1994; Tuchman, 1996; Lowe, 1996; Porter and others, 1997. --, biovolumes not determined]

\begin{tabular}{|c|c|c|c|c|c|c|c|c|c|c|c|c|c|c|c|}
\hline \multirow[b]{2}{*}{ Algal taxa } & \multirow[b]{2}{*}{ Taxon code } & \multirow[b]{2}{*}{ Guild } & \multicolumn{13}{|c|}{ Site and sampling date } \\
\hline & & & $\begin{array}{c}\text { NURCR } \\
7 / 94\end{array}$ & $\begin{array}{c}\text { NURCR } \\
\text { 9/94 }\end{array}$ & $\begin{array}{c}\text { NURCR } \\
\text { 7/95Rep } 1\end{array}$ & $\begin{array}{c}\text { NURCR } \\
\text { 7/95Rep } 2\end{array}$ & $\begin{array}{l}\text { NUSTM } \\
\text { 7/95 }\end{array}$ & $\begin{array}{l}\text { STEAM } \\
7 / 95\end{array}$ & $\begin{array}{c}\text { STEABB } \\
7 / 95\end{array}$ & $\begin{array}{c}\text { COPEG } \\
7 / 95\end{array}$ & $\begin{array}{l}\text { BSODA } \\
7 / 95\end{array}$ & $\begin{array}{l}\text { TOKET } \\
7 / 95\end{array}$ & $\begin{array}{l}\text { LEM1T } \\
7 / 95\end{array}$ & $\begin{array}{l}\text { INLET } \\
7 / 95\end{array}$ & $\begin{array}{l}\text { LAKEM } \\
7 / 95\end{array}$ \\
\hline \multicolumn{16}{|c|}{ Cyanophyta } \\
\hline Nostocaceae spp. ${ }^{1}$ & NOSTSPEC & $\mathrm{NF}$ & 7,181 & 17,765 & 2,833 & 10,425 & 10,839 & 6,149 & 2,645 & 27,160 & 5,930 & 0 & 0 & 10,097 & 0 \\
\hline Oscillatoria spp. ${ }^{2}$ & OSCISPEC & & 0 & 0 & 0 & 0 & 81,290 & 104,549 & 0 & 0 & 29,651 & 0 & 0 & 10,097 & 4,188 \\
\hline Rivulariaceae spp. ${ }^{3}$ & RIVUSPEC & NF & 30,845 & 12,622 & 17,143 & 9,561 & 31,613 & 139,541 & 5,555 & 7,129 & 0 & 0 & 0 & 0 & 0 \\
\hline Scytonema hofmanni & SCYTHOFM & $\mathrm{NF}$ & -- & -- & 0 & 0 & 0 & 0 & 0 & 0 & 0 & 0 & 0 & 0 & 0 \\
\hline Unidentified blue-green algae & CYANOSP1 & & 0 & 0 & 0 & 0 & 0 & -- & 0 & -- & 0 & 0 & 0 & 0 & 0 \\
\hline Unidentified blue-green algae & CYANOSP2 & & 0 & 0 & 0 & -- & 0 & 0 & 0 & 0 & 0 & 0 & 0 & 0 & 0 \\
\hline \multicolumn{16}{|c|}{ Chlorophyta (Green Algae) } \\
\hline Mougeotia sp. & MOUGSPEC & & 0 & 0 & 0 & 0 & 0 & 0 & 0 & 0 & 0 & 8,493 & 0 & 0 & 0 \\
\hline Scenedesmus acutus & SCENACUT & & 0 & 0 & 0 & 0 & 0 & 575 & 0 & 0 & 0 & 0 & 0 & 0 & 0 \\
\hline Scenedesmus quadricauda & SCENQUAD & & 0 & 0 & 0 & 0 & 0 & 0 & 2,063 & 0 & 0 & 0 & 0 & 0 & 0 \\
\hline Stigeoclonium lubricum & STIGLUBR & & 0 & -- & 0 & -- & 0 & 0 & 0 & 0 & 0 & 0 & 0 & 0 & 0 \\
\hline Ulothrix sp. & ULOXSPEC & & 0 & 0 & 0 & 0 & 0 & 0 & 0 & 0 & 0 & 9,597 & 3,819 & 1,616 & 0 \\
\hline \multicolumn{16}{|c|}{ Rhodophyta (Red Algae) } \\
\hline Audouinella violacea & AUDOVIOL & $\mathrm{C}$ & 0 & 0 & 0 & 0 & 0 & 0 & 0 & -- & 0 & 0 & 0 & 0 & 0 \\
\hline
\end{tabular}


Appendix E. Algal data from 1994-95 samplings in the North Umpqua River Basin-Continued

Table E2. Biovolumes of algal taxa collected from 10 sites in the North Umpqua River Basin, Oregon, 1994-95-Continued

[Refer to table 4 for list of site acronyms with station identification numbers and river miles. Taxon biovolumes are given in 1,000 cubic micrometers/square centimeter. Replicate QA samples, Rep 1 and Rep 2, were collected only at NURCR. Some taxa are assigned to autecological guilds as follows: NF, nitrogen fixers, NH; facultative nitrogen heterotrophs; E, eutrophic taxa; O, oligotrophic taxa; A, alkaliphilic taxa; C, cold-water taxa. Sources for autecological classifications are from Patrick and Reimer, 1966, 1975; Schoeman, 1973; Lowe, 1974; Dam and others, 1994; Tuchman, 1996; Lowe, 1996; Porter and others, 1997. --, biovolumes not determined]

\begin{tabular}{|c|c|c|c|c|c|c|c|c|c|c|c|c|c|c|c|}
\hline \multirow[b]{2}{*}{ Algal taxa } & \multirow[b]{2}{*}{ Taxon code } & \multirow[b]{2}{*}{ Guild } & \multicolumn{13}{|c|}{ Site and sampling date } \\
\hline & & & $\begin{array}{l}\text { NURCR } \\
7 / 94\end{array}$ & $\begin{array}{l}\text { NURCR } \\
\text { 9/94 }\end{array}$ & $\begin{array}{c}\text { NURCR } \\
\text { 7/95Rep } 1\end{array}$ & $\begin{array}{c}\text { NURCR } \\
\text { 7/95Rep } 2\end{array}$ & $\begin{array}{l}\text { NUSTM } \\
7 / 95\end{array}$ & $\begin{array}{l}\text { STEAM } \\
7 / 95\end{array}$ & $\begin{array}{c}\text { STEABB } \\
7 / 95\end{array}$ & $\begin{array}{c}\text { COPEG } \\
7 / 95\end{array}$ & $\begin{array}{c}\text { BSODA } \\
7 / 95\end{array}$ & $\begin{array}{l}\text { TOKET } \\
7 / 95\end{array}$ & $\begin{array}{l}\text { LEM1T } \\
\text { 7/95 }\end{array}$ & $\begin{array}{l}\text { INETT } \\
7 / 95\end{array}$ & $\begin{array}{l}\text { LAKEM } \\
\text { 7/95 }\end{array}$ \\
\hline \multicolumn{16}{|c|}{ Chrysophyta (Golden Algae) } \\
\hline Kephyrion sp. ${ }^{4}$ & KEPHSPEC & & 0 & 0 & 0 & 0 & 114 & 0 & 0 & 0 & 0 & 0 & 0 & 959 & 88 \\
\hline \multicolumn{16}{|c|}{ Bacillariophyta (Diatoms) } \\
\hline Achnanthes exigua & ACHNEXIG & $\mathrm{O}, \mathrm{A}$ & 0 & 0 & 0 & 0 & 0 & 0 & 0 & 0 & 0 & 0 & 0 & 0 & 26 \\
\hline Achnanthes lapidosa & ACHNLAPI & $\mathrm{O}$ & 0 & 0 & 0 & 103 & 0 & 0 & 0 & 0 & 0 & 0 & 0 & 0 & 0 \\
\hline Achnanthes linearis & ACHNLINE & $\mathrm{C}$ & 0 & 0 & 0 & 0 & 0 & 0 & 0 & 0 & 783 & 9,501 & 9,453 & 1,333 & 0 \\
\hline Achnanthes sp. & ACHNSPEC & & 0 & 0 & 0 & 0 & 0 & 0 & 0 & 0 & 0 & 0 & 0 & 1,212 & 0 \\
\hline Achnanthidium clevei & ACHNCLEV & $\mathrm{E}, \mathrm{A}$ & 0 & 0 & 0 & 49 & 0 & 0 & 0 & 0 & 0 & 0 & 0 & 0 & 0 \\
\hline Achnanthidium lanceolatum ${ }^{5}$ & ACHDLANC & $\mathrm{E}, \mathrm{A}$ & 1,669 & 0 & 163 & 154 & 325 & 779 & 476 & 126 & 4,270 & 38,866 & 4,297 & 12,722 & 84 \\
\hline Achnanthidium minutissimum & ACHDMINU & & 28,929 & 40,531 & 2,025 & 2,845 & 0 & 779 & 1,455 & 176 & 2,135 & 0 & 13,965 & 1,969 & 307 \\
\hline Amphora perpusilla & AMRAPERP & $\mathrm{NH}, \mathrm{E}$ & 0 & 0 & 0 & 142 & 0 & 0 & 0 & 13 & 0 & 0 & 3,963 & 3,352 & 0 \\
\hline Asterionella formosa & ASRIFORM & A & 0 & 0 & 0 & 252 & 0 & 0 & 0 & 0 & 0 & 5,278 & 10,503 & 0 & 0 \\
\hline Caloneis bacillum & CANEBACI & $\mathrm{O}, \mathrm{A}$ & 0 & 691 & 91 & 0 & 0 & 76 & 0 & 16 & 0 & 0 & 0 & 0 & 0 \\
\hline Cocconeis sp. & CCNESPEC & E & 5,614 & 29,303 & 7,987 & 1,848 & 3,324 & 1,915 & 1,217 & 3,193 & 25,974 & 44,144 & 65,884 & 9,289 & 856 \\
\hline Cyclotella meneghiniana & CYTOMENE & NH,E,A & 0 & 0 & 0 & 0 & 0 & 0 & 0 & 29 & 0 & 0 & 0 & 0 & 0 \\
\hline Cymbella affinis & CYLAAFFI & E,A & 0 & 0 & 1,009 & 794 & 13,006 & 26,486 & 9,522 & 86 & 10,674 & 0 & 42,968 & 0 & 0 \\
\hline Cymbella mexicana ${ }^{6}$ & CYLAMEXI & & 38,242 & 0 & 7,497 & 4,719 & 9,935 & 0 & 0 & 424 & 0 & 0 & 0 & 55,534 & 0 \\
\hline Cymbella turgidula & CYLATUDU & A & 0 & 0 & 227 & 143 & 0 & 568 & 0 & 0 & 0 & 0 & 0 & 0 & 0 \\
\hline Diatoma hiemale mesodon & DIATHYme & $\mathrm{A}, \mathrm{C}$ & 0 & 0 & 0 & 0 & 0 & 0 & 0 & 0 & 4,744 & 748,531 & 19,097 & 48,466 & 0 \\
\hline Diatoma tenиe elongatum & DIATTEel & & 0 & 2,074 & 0 & 0 & 0 & 0 & 0 & 0 & 0 & 0 & 0 & 0 & 0 \\
\hline Diatoma vulgare & DIATVULG & E,A & 18,773 & 40,436 & 2,044 & 0 & 0 & 0 & 0 & 69 & 0 & 0 & 93,574 & 59,370 & 0 \\
\hline Diploneis elliptica & DINEELLI & A & 0 & 0 & 0 & 0 & 0 & 0 & 0 & 0 & 0 & 0 & 0 & 5,250 & 0 \\
\hline Encyonema minutum & ENCYMINU & $\mathrm{NH}, \mathrm{E}$ & 7,301 & 10,368 & 1,295 & 300 & 2,005 & 2,895 & 9,787 & 81 & 15,359 & 35,507 & 17,665 & 0 & 0 \\
\hline Encyonema muelleri & ENCYMUEL & $\mathrm{O}$ & 22,946 & 5,184 & 1,908 & 257 & 0 & 0 & 0 & 443 & 0 & 0 & 0 & 0 & 0 \\
\hline Epithemia sp. ${ }^{7}$ & EPITSPEC & NF,A & 67,655 & 201,771 & 30,946 & 56,588 & 40,446 & 70,688 & 285,882 & 20,710 & 526,749 & 27,350 & 101,452 & 128,737 & 1,978 \\
\hline Fragilaria capucina ${ }^{8}$ & FRAGCAPU & E,A & 0 & 0 & 0 & 0 & 0 & 0 & 0 & 0 & 0 & 0 & 24,348 & 30,897 & 0 \\
\hline Fragilaria construens ${ }^{9}$ & FRAGCOEN & E,A & 477 & 3,199 & 654 & 530 & 0 & 0 & 0 & 302 & 11,006 & 10,364 & 66,915 & 15,267 & 11 \\
\hline Fragilaria vaucheriae & FRAGVACH & E,A,C & 4,005 & 6,967 & 2,486 & 165 & 520 & 0 & 0 & 45 & 1,708 & 265,325 & 6,875 & 14,831 & 516 \\
\hline Frustulia vulgaris & FRUSVULAG & A & 0 & 0 & 0 & 172 & 0 & 0 & 0 & 0 & 0 & 0 & 0 & 0 & 0 \\
\hline Gomphoneis eriense ${ }^{10}$ & GONSERIE & & 7,416 & 19,907 & 581 & 1,830 & 0 & 3,633 & 0 & 0 & 0 & 0 & 0 & 0 & 0 \\
\hline Gomphoneis herculeana & GONSHERC & $\mathrm{E}, \mathrm{C}$ & 14,832 & 88,474 & 0 & 0 & 0 & 8,477 & 0 & 0 & 0 & 0 & 128,903 & 0 & 0 \\
\hline
\end{tabular}


Appendix E. Algal data from 1994-95 samplings in the North Umpqua River Basin-Continued

Table E2. Biovolumes of algal taxa collected from 10 sites in the North Umpqua River Basin, Oregon, 1994-95-Continued

[Refer to table 4 for list of site acronyms with station identification numbers and river miles. Taxon biovolumes are given in 1,000 cubic micrometers/square centimeter. Replicate QA samples, Rep 1 and Rep 2, were collected only at NURCR. Some taxa are assigned to autecological guilds as follows: NF, nitrogen fixers, NH; facultative nitrogen heterotrophs; E, eutrophic taxa; O, oligotrophic taxa; A, alkaliphilic taxa; C, cold-water taxa. Sources for autecological classifications are from Patrick and Reimer, 1966, 1975; Schoeman, 1973; Lowe, 1974; Dam and others, 1994; Tuchman, 1996; Lowe, 1996; Porter and others, 1997. --, biovolumes not determined]

\begin{tabular}{|c|c|c|c|c|c|c|c|c|c|c|c|c|c|c|c|}
\hline \multirow[b]{2}{*}{ Algal taxa } & \multirow[b]{2}{*}{ Taxon code } & \multirow[b]{2}{*}{ Guild } & \multicolumn{13}{|c|}{ Site and sampling date } \\
\hline & & & $\begin{array}{c}\text { NURCR } \\
7 / 94\end{array}$ & $\begin{array}{c}\text { NURCR } \\
\text { 9/94 }\end{array}$ & $\begin{array}{c}\text { NURCR } \\
\text { 7/95Rep } 1\end{array}$ & $\begin{array}{c}\text { NURCR } \\
\text { 7/95Rep } 2\end{array}$ & $\begin{array}{l}\text { NUSTM } \\
7 / 95\end{array}$ & $\begin{array}{c}\text { STEAM } \\
7 / 95\end{array}$ & $\begin{array}{c}\text { STEABB } \\
7 / 95\end{array}$ & $\begin{array}{c}\text { COPEG } \\
7 / 95\end{array}$ & $\begin{array}{l}\text { BSODA } \\
7 / 95\end{array}$ & $\begin{array}{l}\text { TOKET } \\
\text { 7/95 }\end{array}$ & $\begin{array}{l}\text { LEMIT } \\
7 / 95\end{array}$ & $\begin{array}{l}\text { INLET } \\
7 / 95\end{array}$ & $\begin{array}{l}\text { LAKEM } \\
7 / 95\end{array}$ \\
\hline \multicolumn{16}{|c|}{ Bacillariophyta (Diatoms)—Continued } \\
\hline Gomphoneis olivacea $^{11}$ & GONSOLIV & $\mathrm{E}$ & 0 & 0 & 0 & 183 & 0 & 0 & 0 & 25 & 0 & 0 & 0 & 2,272 & 0 \\
\hline Gomphonema angustatum & GONEANSM & E,A & 0 & 0 & 0 & 0 & 325 & 0 & 476 & 0 & 0 & 12,955 & 0 & 5,452 & 168 \\
\hline Gomphonema clevei & GONECLEVI & & 209 & 0 & 2,290 & 1519 & 163 & 3,713 & 0 & 126 & 534 & 0 & 2,148 & 0 & 21 \\
\hline Gomphonema gracile & GONEGRAC & & 0 & 0 & 0 & 0 & 0 & 0 & 0 & 0 & 1,453 & 0 & 0 & 0 & 0 \\
\hline Gomphonema intricatum & GONEINTR & $\mathrm{E}, \mathrm{A}$ & 0 & 0 & 0 & 0 & 0 & 0 & 0 & 39 & 0 & 0 & 0 & 0 & 0 \\
\hline Gomphonema parvulum & GONEPARV & NH,E,A & 0 & 0 & 0 & 172 & 0 & 0 & 0 & 47 & 0 & 0 & 0 & 0 & 0 \\
\hline Gomphonema rhombicum & GONERHOM & & 16,836 & 18,829 & 37,131 & 4,934 & 0 & 9,622 & 0 & 4,018 & 0 & 0 & 0 & 0 & 0 \\
\hline Gomphonema subclavatum & GONESUCL & $\mathrm{O}$ & 0 & 0 & 0 & 0 & 5,419 & 0 & 0 & 0 & 10,674 & 14,395 & 14,323 & 6,058 & 5,221 \\
\hline Gomphonema tenellum & GONETENE & & 0 & 0 & 0 & 0 & 0 & 0 & 0 & 0 & 0 & 0 & 0 & 0 & 49 \\
\hline Gomphonema ventricosum & GONEVENT & $\mathrm{O}$ & 0 & 0 & 0 & 0 & 0 & 0 & 0 & 0 & 0 & 0 & 40,581 & 0 & 0 \\
\hline Hannaea arcus & HANNARC & $\mathrm{C}$ & 0 & 6,048 & 0 & 0 & 0 & 0 & 0 & 0 & 0 & 125,955 & 41,774 & 53,009 & 814 \\
\hline Melosira varians & MELOVARI & NH,E,A & 0 & 0 & 0 & 0 & 0 & 0 & 0 & 0 & 7,709 & 633,132 & 46,548 & 10,097 & 0 \\
\hline Navicula anglica & NAVEANGL & & 0 & 0 & 0 & 0 & 0 & 0 & 0 & 0 & 0 & 0 & 0 & 3,635 & 0 \\
\hline Navicula cascadensis & NAVECASC & & 0 & 0 & 0 & 0 & 0 & 0 & 0 & 0 & 0 & 0 & 0 & 1,212 & 0 \\
\hline Navicula contenta biceps & NAVECObi & & 0 & 0 & 0 & 0 & 0 & 0 & 0 & 0 & 474 & 0 & 0 & 0 & 0 \\
\hline Navicula cryptocephala & NAVECRCE & NH,E,A & 0 & 0 & 0 & 0 & 0 & 0 & 754 & 0 & 6,197 & 2,279 & 4,535 & 3,786 & 44 \\
\hline Navicula decussis & NAVEDECU & & 0 & 0 & 0 & 110 & 0 & 0 & 0 & 0 & 0 & 0 & 0 & 0 & 0 \\
\hline Navicula exigua capitata & NAVEEXca & $\mathrm{E}, \mathrm{A}$ & 0 & 0 & 0 & -- & 0 & 0 & 0 & 0 & 0 & 0 & 0 & 0 & 0 \\
\hline Navicula graciloides & NAVEGRAC & $\mathrm{E}, \mathrm{A}$ & 0 & 0 & 0 & 0 & 0 & 0 & 0 & 0 & 2,580 & 0 & 0 & 0 & 0 \\
\hline Navicula menisculus & NAVEMELU & E,A & 0 & 0 & 0 & 0 & 0 & 113 & 0 & 0 & 0 & 0 & 0 & 0 & 0 \\
\hline Navicula minima & NAVEMINI & NH,E,A & 603 & 0 & 0 & 0 & 0 & 0 & 116 & 0 & 261 & 0 & 1,050 & 1,333 & 0 \\
\hline Navicula mournei & NAVEMOUR & & 0 & 0 & 0 & 0 & 0 & 0 & 0 & 0 & 0 & 0 & 5,610 & 0 & 0 \\
\hline Navicula notha & NAVENOTA & & 0 & 0 & 0 & 257 & 0 & 0 & 0 & 0 & 0 & 0 & 0 & 0 & 0 \\
\hline Navicula radiosa & NAVERADI & & 695 & 0 & 136 & 0 & 0 & 0 & 0 & 70 & 0 & 0 & 0 & 3,282 & 0 \\
\hline Navicula reinhartii & NAVEREIN & $\mathrm{E}, \mathrm{A}$ & 0 & 0 & 0 & 0 & 0 & 0 & 0 & 0 & 0 & 0 & 0 & 5,250 & 0 \\
\hline Navicula salinarum intermedia & NAVESAin & $\mathrm{E}$ & 0 & 0 & 216 & 272 & 0 & 360 & 0 & 443 & 0 & 0 & 0 & 0 & 0 \\
\hline Navicula schoenfeldii & NAVESCHO & & 0 & -- & 0 & -- & 0 & 0 & 0 & 0 & 0 & 0 & 0 & 0 & 0 \\
\hline Navicula sp. & NAVESPEC & & 0 & 0 & 0 & 0 & 0 & 0 & 0 & 0 & 0 & 0 & 3,581 & 1,515 & 0 \\
\hline Navicula sp. 1 ans hdsn & NAVESPE1A & & 0 & 2,074 & 477 & 515 & 0 & 0 & 0 & 58 & 0 & 0 & 0 & 0 & 0 \\
\hline Navicula viridula avenacea & NAVEVIav & $\mathrm{E}, \mathrm{A}$ & 0 & 0 & 409 & 129 & 0 & 0 & 0 & 0 & 0 & 0 & 0 & 0 & 0 \\
\hline Nitzschia amphibia & NITZAMPH & NH,E,A & 0 & 0 & 0 & 0 & 0 & 0 & 0 & 0 & 569 & 0 & 0 & 0 & 0 \\
\hline Nitzschia communis & NITZCONI & NH,E,A & 0 & 0 & 0 & 0 & 0 & 0 & 0 & 0 & 0 & 0 & 1,074 & 0 & 0 \\
\hline
\end{tabular}


Appendix E. Algal data from 1994-95 samplings in the North Umpqua River Basin-Continued

Table E2. Biovolumes of algal taxa collected from 10 sites in the North Umpqua River Basin, Oregon, 1994-95-Continued

[Refer to table 4 for list of site acronyms with station identification numbers and river miles. Taxon biovolumes are given in 1,000 cubic micrometers/square centimeter. Replicate QA samples, Rep 1 and Rep 2, were collected only at NURCR. Some taxa are assigned to autecological guilds as follows: NF, nitrogen fixers, NH; facultative nitrogen heterotrophs; E, eutrophic taxa; O, oligotrophic taxa; A, alkaliphilic taxa; C, cold-water taxa. Sources for autecological classifications are from Patrick and Reimer, 1966, 1975; Schoeman, 1973; Lowe, 1974; Dam and others, 1994; Tuchman, 1996; Lowe, 1996; Porter and others, 1997. --, biovolumes not determined]

\begin{tabular}{|c|c|c|c|c|c|c|c|c|c|c|c|c|c|c|c|}
\hline \multirow[b]{2}{*}{ Algal taxa } & \multirow[b]{2}{*}{ Taxon code } & \multirow[b]{2}{*}{ Guild } & \multicolumn{13}{|c|}{ Site and sampling date } \\
\hline & & & $\begin{array}{l}\text { NURCR } \\
\text { 7/94 }\end{array}$ & $\begin{array}{c}\text { NURCR } \\
\text { 9/94 }\end{array}$ & $\begin{array}{c}\text { NURCR } \\
\text { 7/95Rep } 1\end{array}$ & \begin{tabular}{|c|} 
NURCR \\
7/95Rep 2
\end{tabular} & $\begin{array}{l}\text { NUSTM } \\
7 / 95\end{array}$ & $\begin{array}{c}\text { STEAM } \\
\text { 7/95 }\end{array}$ & $\begin{array}{l}\text { STEABB } \\
\text { 7/95 }\end{array}$ & $\begin{array}{c}\text { COPEG } \\
7 / 95\end{array}$ & $\begin{array}{l}\text { BSODA } \\
\text { 7/95 }\end{array}$ & $\begin{array}{c}\text { TOKET } \\
\text { 7/95 }\end{array}$ & $\begin{array}{l}\text { LEM1T } \\
\text { 7/95 }\end{array}$ & $\begin{array}{l}\text { INLET } \\
7 / 95\end{array}$ & $\begin{array}{l}\text { LAKEM } \\
7 / 95\end{array}$ \\
\hline \multicolumn{16}{|c|}{ Bacillariophyta (Diatoms)—Continued } \\
\hline Nitzschia dissipata & NITZDISS & $\mathrm{E}, \mathrm{A}$ & 0 & 0 & 0 & 154 & 0 & 0 & 0 & 0 & 1,595 & 51,629 & 77,056 & 8,148 & 0 \\
\hline Nitzschia frustulum & NITZFRUS & NH,E,A & 37,655 & 79,067 & 4,670 & 3,414 & 0 & 627 & 635 & 309 & 4,981 & 2,879 & 64,165 & 2,423 & 56 \\
\hline Nitzschia frustulum perminuta & NITZFRpe & $\mathrm{O}$ & 9,271 & 19,873 & 1,817 & 286 & 0 & 0 & 0 & 39 & 0 & 0 & 0 & 0 & 0 \\
\hline Nitzschia frustulum subsalina & NITZFRsu & & 3,477 & 0 & 0 & 0 & 0 & 0 & 0 & 0 & 0 & 0 & 0 & 0 & 0 \\
\hline Nitzschia linearis & NITZLINE & NH,E,A & 0 & 0 & 0 & 0 & 0 & 0 & 0 & 0 & 0 & 0 & 36,379 & 0 & 0 \\
\hline Nitzschia palea & NITZPALE & NH,E & 0 & 1,244 & 0 & 0 & 0 & 0 & 0 & 0 & 0 & 0 & 0 & 0 & 0 \\
\hline Nitzschia paleacea & NITZPACE & $\mathrm{NH}, \mathrm{E}$ & 0 & 0 & 0 & 0 & 0 & 0 & 0 & 0 & 0 & 7,053 & 4,679 & 0 & 0 \\
\hline Nitzschia sp. & NITZSPEC & & 0 & 0 & 0 & 0 & 0 & 0 & 0 & 0 & 0 & 0 & 5,729 & 0 & 0 \\
\hline Nitzschia tropica & NITZSTROP & & 0 & 0 & 0 & 286 & 0 & 0 & 0 & 19 & 0 & 0 & 0 & 0 & 0 \\
\hline Nitzschia volcanica & NITZVOLC & & 0 & 0 & 0 & 0 & 0 & 0 & 423 & 0 & 0 & 0 & 0 & 0 & 0 \\
\hline Pseudostaurosira brevistriata $^{12}$ & PSSTBREV & & 831 & 826 & 543 & 273 & 0 & 0 & 0 & 319 & 0 & 0 & 0 & 0 & 38 \\
\hline Reimeria sinuata & REIMSINU & E & 301 & 0 & 1,004 & 223 & 0 & 0 & 0 & 0 & 830 & 0 & 0 & 0 & 0 \\
\hline Rhoicosphenia curvata ${ }^{13}$ & RHSPCURV & E,A & 18,542 & 17,281 & 6,361 & 2,860 & 423 & 2,460 & 928 & 699 & 0 & 5,614 & 0 & 1,181 & 54 \\
\hline Rhopalodia gibba ${ }^{14}$ & RHOPGIBA & NF,E,A & 0 & 4,804 & 0 & 398 & 0 & 1,052 & 406,272 & 108 & 0 & 0 & 0 & 0 & 0 \\
\hline Sellaphora pupula & SELAPUPU & & 0 & 0 & 0 & 0 & 0 & 0 & 0 & 31 & 0 & 0 & 0 & 0 & 0 \\
\hline Staurosirella pinnata ${ }^{15}$ & STSIPINN & E & 15,707 & 10,646 & 2,006 & 705 & 0 & 0 & 0 & 571 & 712 & 2,879 & 0 & 0 & 28 \\
\hline Synedra mazamaensis & SYNEMAZA & A & 0 & 2,654 & 0 & 0 & 0 & 0 & 677 & 0 & 1,518 & 0 & 0 & 0 & 0 \\
\hline Synedra minuscula & SYNEMINU & & 2,271 & 0 & 0 & 0 & 0 & 0 & 0 & 0 & 0 & 0 & 0 & 0 & 0 \\
\hline Synedra parasitica & SYNEPARA & & 0 & 0 & 0 & 0 & 0 & 0 & 0 & 0 & 0 & 0 & 0 & 1,414 & 0 \\
\hline Synedra radians & SYNERADI & $\mathrm{E}, \mathrm{A}$ & 0 & 0 & 0 & 0 & 0 & 0 & 0 & 0 & 0 & 0 & 0 & 0 & 84 \\
\hline Synedra rumpens & SYNERUMP & E & 0 & 0 & 254 & 480 & 0 & 0 & 0 & 260 & 0 & 0 & 0 & 0 & 33 \\
\hline Synedra ulna & SYNEULNA & E,A & 44,500 & 74,651 & 4,906 & 6,521 & 0 & 558 & 48,298 & 558 & 0 & 103,883 & 0 & 0 & 544 \\
\hline \multicolumn{3}{|l|}{ Total biovolume } & $4.1 \times 10^{8}$ & $7.2 \times 10^{8}$ & $1.4 \times 10^{5}$ & $1.1 \times 10^{5}$ & $2.0 \times 10^{5}$ & $3.8 \times 10^{5}$ & $7.8 \times 10^{5}$ & $6.8 \times 10^{4}$ & $6.8 \times 10^{5}$ & $2.2 \times 10^{6}$ & $9.6 \times 10^{5}$ & $5.2 \times 10^{5}$ & $1.5 \times 10^{4}$ \\
\hline $\begin{array}{l}\text { Includes Nostoc spongiiforme } \\
2 \text { Includes Oscillitoria sp and } H \\
3 \text { Includes Rivularia sp., Caloth } \\
{ }^{4} \text { Includes Kephyrion sp. and } K \text {. } \\
{ }^{5} \text { Includes Achnanthidium lance } \\
{ }^{6} \text { Includes Cymbella mexicana } \text { a } \\
{ }^{7} \text { Includes Epithemia } \text { sp., E. adn }\end{array}$ & $\begin{array}{l}\text { and Anabaena } \mathrm{sp} \\
\text { drocoleum breb } \\
\text { ix parietina, and } \\
\text { littorale. } \\
\text { olata } \text { and } A \text {. lanc } \\
\text { nd } C \text {. mexicana } \\
\text { ata, E. sorex, an }\end{array}$ & $\begin{array}{l}\text { sonii. } \\
\text { Amphithri } \\
\text { olatum du } \\
\text { nischii. } \\
\text { E. turgido }\end{array}$ & $\begin{array}{l}\text { janthina. } \\
\text { bium. }\end{array}$ & & $\begin{array}{l}{ }^{9} \text { Includ } \\
{ }^{10} \text { Includ } \\
{ }^{11} \text { Includ } \\
{ }^{12} \text { Includ } \\
{ }^{13} \text { Includ } \\
{ }^{14} \text { Includ } \\
{ }^{15} \text { Incluc }\end{array}$ & $\begin{array}{l}\text { es Fragilar } \\
\text { es Gompho } \\
\text { les Gompho } \\
\text { es Pseudos } \\
\text { les Rhoicos } \\
\text { les Rhopalc } \\
\text { les Stauros }\end{array}$ & $\begin{array}{l}\text { ia construc } \\
\text { neis erien } \\
\text { oneis oliva } \\
\text { taurosira b } \\
\text { phenia ab } \\
\text { dia gibba } \\
\text { irella pinn }\end{array}$ & $\begin{array}{l}\text { ens, F. con } \\
\text { s and } G . \text { er } \\
\text { cea and } G \text {. } \\
\text { brevistriata } \\
\text { breviata an } \\
\text { and } R . \text { gib } \\
\text { ata, and } F \text {. }\end{array}$ & $\begin{array}{l}\text { truens pun } \\
\text { iens variab } \\
\text { olivacea } h \\
\text {, Fragilaric } \\
\text { d } R \text {. curvat } \\
\text { ba ventrico } \\
\text { pinnata lar }\end{array}$ & $\begin{array}{l}\text { ilis. } \\
\text { utchinsonic } \\
\text { a brevistria } \\
\text { a. } \\
\text { sa. } \\
\text { cettula. }\end{array}$ & $\begin{array}{l}\text { ina. } \\
\text { ta and } F \text {. }\end{array}$ & vistriata & nflata. & & \\
\hline
\end{tabular}


Appendix E. Algal data from 1994-95 samplings in the North Umpqua River Basin-Continued

Table E3. Densities of algal taxa collected from 10 sites in the North Umpqua River Basin, Oregon, 1994-95

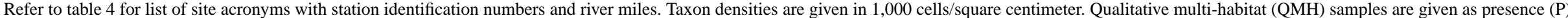

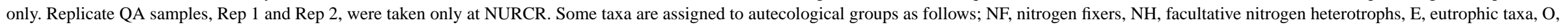

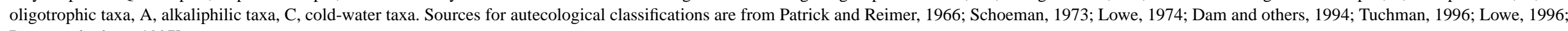
Porter and others, 1997]

\section{Site and sampling date}

\begin{tabular}{|c|c|c|c|c|c|c|c|c|c|c|c|c|c|c|c|c|c|}
\hline Algal taxa & Taxon code & Guild & $\begin{array}{l}\text { NURCR } \\
\text { 7/94OMH }\end{array}$ & $\begin{array}{l}\text { NURCR } \\
\text { 9/94OMH }\end{array}$ & $\begin{array}{l}\text { NURCR } \\
7 / 94\end{array}$ & $\begin{array}{l}\text { NURCR } \\
\text { 9/94 }\end{array}$ & $\begin{array}{c}\text { NURCR } \\
\text { 7/95Rep } 1\end{array}$ & $\begin{array}{c}\text { NURCR } \\
\text { 7/95Rep } 2\end{array}$ & $\begin{array}{l}\text { NUSTM } \\
\text { 7/95 }\end{array}$ & $\begin{array}{l}\text { STEAM } \\
7 / 95\end{array}$ & $\begin{array}{c}\text { STEABB } \\
\text { 7/95 }\end{array}$ & $\begin{array}{c}\text { COPEG } \\
7 / 95\end{array}$ & $\begin{array}{l}\text { BSODA } \\
\text { 7/95 }\end{array}$ & $\begin{array}{l}\text { TOKET } \\
\text { 7/95 }\end{array}$ & $\begin{array}{l}\text { LEMIT } \\
7 / 95\end{array}$ & $\begin{array}{l}\text { INLET } \\
7 / 95\end{array}$ & $\begin{array}{l}\text { LAKEM } \\
7 / 95\end{array}$ \\
\hline \multicolumn{18}{|c|}{ Cyanocphyta (Blue-green algae) } \\
\hline Nostocaceae spp. ${ }^{1}$ & NOSTSPEC & $\mathrm{NF}$ & & & 254 & 628 & 100 & 368 & 5 & 217 & 3 & 960 & 6 & 0 & 0 & 10 & 0 \\
\hline Oscillatoria spp. $^{2}$ & OSCISPEC & & & & 0 & 0 & 0 & 0 & 81 & 1,145 & 0 & 0 & 30 & 0 & 0 & 10 & 4 \\
\hline Rivulariaceae spp. ${ }^{3}$ & RIVUSPEC & $\mathrm{NF}$ & & & 5,318 & 2,176 & 2,956 & 1,648 & 36 & 4,314 & 8 & 644 & 0 & 0 & 0 & 0 & 0 \\
\hline Scytonema hofmannii & SCYTHOFM & $\mathrm{NF}$ & & & 207 & 159 & 0 & 0 & 0 & 0 & 0 & 0 & 0 & 0 & 0 & 0 & 0 \\
\hline Unidentified blue-green algae & CYANOSP1 & & & & 0 & 0 & 0 & 0 & 0 & 69 & 0 & 7 & 0 & 0 & 0 & 0 & 0 \\
\hline Unidentified blue-green algae & CYANOSP2 & & & & 0 & 0 & 0 & 11 & 0 & 0 & 0 & 0 & 0 & 0 & 0 & 0 & 0 \\
\hline
\end{tabular}

जे

Scenedesmus acutus

SCENACUT

Scenedesmus quadricauda

SCENQUAD

Stigeoclonium lubricum

STIGLUBR

Ulothrix sp.

ULOXSPEC

$0 \quad 0$

\begin{tabular}{|c|c|c|c|c|c|c|c|c|c|c|c|c|c|c|c|c|c|}
\hline Audouinella violacea & AUDOVIOL & $\mathrm{C}$ & & & 0 & 0 & 0 & 0 & 0 & 0 & 0 & 3 & 0 & 0 & 0 & 0 & 0 \\
\hline \multicolumn{18}{|c|}{ Chrysophyta (Golden Algae) } \\
\hline Kephyrion $\mathrm{sp}^{4}$ & KEPHSPEC & & & & 0 & 0 & 0 & 0 & 2 & 0 & 0 & 0 & 0 & 0 & 0 & 10 & 1 \\
\hline \multicolumn{18}{|c|}{ Bacillariophyta (Diatoms) } \\
\hline Achnanthes exigua & ACHNEXIG & $\mathrm{O}, \mathrm{A}$ & & & 0 & 0 & 0 & 0 & 0 & 0 & 0 & 0 & 0 & 0 & 0 & 0 & 1 \\
\hline Achnanthes lapidosa & ACHNLAPI & $\mathrm{O}$ & & & 0 & 0 & 0 & 1 & 0 & 0 & 0 & 0 & 0 & 0 & 0 & 0 & 0 \\
\hline Achnanthes linearis & ACHNLINE & $\mathrm{C}$ & $\mathrm{P}$ & & 0 & 0 & 0 & 0 & 0 & 0 & 0 & 0 & 6 & 48 & 72 & 10 & 0 \\
\hline Achnanthes sp. & ACHNSPEC & & & & 0 & 0 & 0 & 0 & 0 & 0 & 0 & 0 & 0 & 0 & 0 & 10 & 0 \\
\hline Achnanthidium clevei & ACHNCLEV & $\mathrm{E}, \mathrm{A}$ & & & 0 & 0 & 0 & 0.2 & 0 & 0 & 0 & 0 & 0 & 0 & 0 & 0 & 0 \\
\hline Achnanthidium lanceolatum ${ }^{5}$ & ACHDLANC & $\mathrm{E}, \mathrm{A}$ & & $P$ & 9 & 0 & 1 & 1 & 2 & 0 & 3 & 1 & 24 & 216 & 24 & 71 & 0.5 \\
\hline Achnanthidium minutissimum & ACHDMINU & & & & 422 & 591 & 30 & 41 & 0 & 11 & 29 & 3 & 36 & 0 & 215 & 30 & 6 \\
\hline Amphora perpusilla & AMRAPERP & $\mathrm{NH}, \mathrm{E}$ & & & 0 & 0 & 0 & 1 & 0 & 0 & 0 & 0.1 & 0 & 0 & 24 & 20 & 0 \\
\hline Asterionella formosa & ASRIFORM & A & & & 0 & 0 & 0 & 1 & 0 & 0 & 0 & 0 & 0 & 24 & 48 & 0 & 0 \\
\hline Caloneis bacillum & CANEBACI & $\mathrm{O}, \mathrm{A}$ & & & 0 & 7 & 1 & 0 & 0 & 1 & 0 & 0.2 & 0 & 0 & 0 & 0 & 0 \\
\hline Cocconeis sp. & CCNESPEC & $\mathrm{E}$ & $\mathrm{P}$ & $\mathrm{P}$ & 14 & 73 & 18 & 5 & 7 & 4 & 3 & 7.3 & 54 & 96 & 143 & 20 & 2 \\
\hline
\end{tabular}




\section{Appendix E. Algal data from 1994-95 samplings in the North Umpqua River Basin-Continued}

Table E3. Densities of algal taxa collected from 10 sites in the North Umpqua River Basin, Oregon, 1994-95-Continued

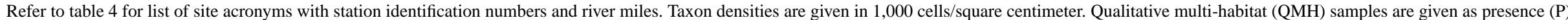

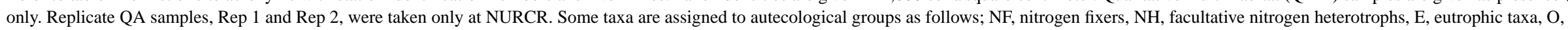

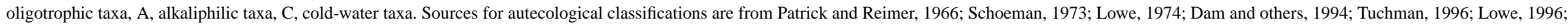
Porter and others, 19971

\begin{tabular}{|c|c|c|c|c|c|c|c|c|c|c|c|c|c|c|c|c|c|}
\hline \multirow[b]{2}{*}{ Algal taxa } & \multirow[b]{2}{*}{ Taxon code } & \multirow[b]{2}{*}{ Guild } & \multicolumn{15}{|c|}{ Site and sampling date } \\
\hline & & & $\begin{array}{l}\text { NURCR } \\
\text { 7/94GMMH }\end{array}$ & $\begin{array}{l}\text { NURCR } \\
\text { 9/94CMH }\end{array}$ & $\begin{array}{l}\text { NURCR } \\
7 / 94\end{array}$ & $\begin{array}{l}\text { NURCR } \\
9 / 94\end{array}$ & $\begin{array}{c}\text { NURCR } \\
\text { 7/95Rep } 1\end{array}$ & $\begin{array}{c}\text { NURCR } \\
\text { 7/95Rep } 2\end{array}$ & $\begin{array}{l}\text { NUSTM } \\
7 / 95\end{array}$ & $\begin{array}{l}\text { STEAM } \\
\text { 7/95 }\end{array}$ & $\begin{array}{l}\text { STEABB } \\
7 / 95\end{array}$ & $\begin{array}{c}\text { COPEG } \\
7 / 95\end{array}$ & $\begin{array}{c}\text { BSODA } \\
7 / 95\end{array}$ & $\begin{array}{l}\text { TOKET } \\
7 / 95\end{array}$ & $\begin{array}{l}\text { LEMIT } \\
7 / 95\end{array}$ & $\begin{array}{l}\text { INLET } \\
7 / 95\end{array}$ & $\begin{array}{l}\text { LAKEM } \\
\text { 7/95 }\end{array}$ \\
\hline \multicolumn{18}{|c|}{ Bacillariophyta (Diatoms)—Continued } \\
\hline Cyclotella meneghiniana & CYTOMENE & NH,E,A & & & 0 & 0 & 0 & 0 & 0 & 0 & 0 & 0.1 & 0 & 0 & 0 & 0 & 0 \\
\hline Cymbella affinis & CYLAAFFI & $\mathrm{E}, \mathrm{A}$ & $\mathrm{P}$ & & 0 & 0 & 2 & 1 & 7 & 48 & 5 & 0.2 & 6 & 0 & 24 & 0 & 0 \\
\hline Cymbella mexicana ${ }^{6}$ & CYLAMEXI & & $\mathrm{P}$ & $\mathrm{P}$ & 7 & 0 & 1 & 1 & 2 & 0 & 0 & 0.1 & 0 & 0 & 0 & 10 & 0 \\
\hline Cymbella tumida & CYLATUMD & A & $\mathrm{P}$ & & 0 & 0 & 0 & 0 & 0 & 0 & 0 & 0 & 0 & 0 & 0 & 0 & 0 \\
\hline Cymbella turgidula & CYLATUDU & A & & & 0 & 0 & 1 & 1 & 0 & 2 & 0 & 0 & 0 & 0 & 0 & 0 & 0 \\
\hline Diatoma hiemale mesodon & DIATHYme & A, C & & & 0 & 0 & 0 & 0 & 0 & 0 & 0 & 0 & 6 & 624 & 24 & 40 & 0 \\
\hline Diatoma tenue elongatum & DIATTEel & & & & 0 & 7 & 0 & 0 & 0 & 0 & 0 & 0 & 0 & 0 & 0 & 0 & 0 \\
\hline Diatoma vulgare & DIATVULG & E,A & $\mathrm{P}$ & $\mathrm{P}$ & 21 & 45 & 2 & 0 & 0 & 0 & 0 & 0.1 & 0 & 0 & 48 & 20 & 0 \\
\hline Diploneis elliptica & DINEELLI & A & & & 0 & 0 & 0 & 0 & 0 & 0 & 0 & 0 & 0 & 0 & 0 & 20 & 0 \\
\hline Encyonema minutum & ENCYMINU & $\mathrm{NH}, \mathrm{E}$ & $P$ & $P$ & 49 & 69 & 9 & 2 & 5 & 19 & 26 & 1 & 42 & 96 & 48 & 0 & 0 \\
\hline Encyonema muelleri & ENCYMUEL & $\mathrm{O}$ & & & 153 & 35 & 13 & 2 & 0 & 0 & 0 & 3 & 0 & 0 & 0 & 0 & 0 \\
\hline Epithemia sp. $^{7}$ & EPITSPEC & NF,A & $\mathrm{P}$ & $\mathrm{P}$ & 21 & 62 & 10 & 17 & 11 & 45 & 130 & 8 & 113 & 24 & 24 & 20 & 0.5 \\
\hline Fragilaria capucina $^{8}$ & FRAGCAPU & E,A & $\mathrm{P}$ & & 0 & 0 & 0 & 0 & 0 & 0 & 0 & 0 & 0 & 0 & 24 & 10 & 0 \\
\hline Fragilaria construens ${ }^{9}$ & FRAGCOEN & E,A & & $\mathrm{P}$ & 5 & 31 & 6 & 5 & 0 & 0 & 0 & 3 & 89 & 48 & 645 & 141 & 0.2 \\
\hline Fragilaria vaucheriae & FRAGVACH & $\mathrm{E}, \mathrm{A}, \mathrm{C}$ & $P$ & & 14 & 24 & 9 & 1 & 2 & 0 & 0 & 0.2 & 6 & 576 & 24 & 30 & 2 \\
\hline Frustulia rhomboides & FRUSRHOM & $\mathrm{O}$ & & $\mathrm{P}$ & 0 & 0 & 0 & 0 & 0 & 0 & 0 & 0 & 0 & 0 & 0 & 0 & 0 \\
\hline Frustulia vulgaris & FRUSVULAG & A & & & 0 & 0 & 0 & 0.2 & 0 & 0 & 0 & 0 & 0 & 0 & 0 & 0 & 0 \\
\hline Gomphoneis eriense $^{10}$ & GONSERIE & & & & 12 & 31 & 1 & 3 & 0 & 6 & 0 & 0 & 0 & 0 & 0 & 0 & 0 \\
\hline Gomphoneis herculeana & GONSHERC & $\mathrm{E}, \mathrm{C}$ & $P$ & $\mathrm{P}$ & 5 & 28 & 0 & 0 & 0 & 3 & 0 & 0 & 0 & 0 & 24 & 0 & 0 \\
\hline Gomphoneis olivacea $^{11}$ & GONSOLIV & E & & & 0 & 0 & 0 & 1 & 0 & 0 & 0 & 0.1 & 0 & 0 & 0 & 10 & 0 \\
\hline Gomphonema angustatum & GONEANSM & E,A & $\mathrm{P}$ & $\mathrm{P}$ & 0 & 0 & 0 & 0 & 2 & 0 & 3 & 0 & 0 & 72 & 0 & 20 & 1 \\
\hline Gomphonema clevei & GONECLEVI & & & & 2 & & 25 & 17 & 2 & 41 & 0 & 1 & 6 & 0 & 24 & 0 & 0.2 \\
\hline Gomphonema gracile & GONEGRAC & & & & 0 & 0 & 0 & 0 & 0 & 0 & 0 & 0 & 6 & 0 & 0 & 0 & 0 \\
\hline Gomphonema intricatum & GONEINTR & E,A & & & 0 & 0 & 0 & 0 & 0 & 0 & 0 & 0.2 & 0 & 0 & 0 & 0 & 0 \\
\hline Gomphonema parvulum & GONEPARV & NH,E,A & & & 0 & 0 & 0 & 1 & 0 & 0 & 0 & 0.2 & 0 & 0 & 0 & 0 & 0 \\
\hline Gomphonema rhombicum & GONERHOM & & & & 19 & 21 & 41 & 5 & 0 & 11 & 0 & 4 & 0 & 0 & 0 & 0 & 0 \\
\hline Gomphonema subclavatum & GONESUCL & $\mathrm{O}$ & $\mathrm{P}$ & $\mathrm{P}$ & 0 & 0 & 0 & 0 & 9 & 0 & 0 & 0 & 18 & 24 & 24 & 10 & 5 \\
\hline Gomphonema tenellum & GONETENE & & & & 0 & 0 & 0 & 0 & 0 & 0 & 0 & 0 & 0 & 0 & 0 & 0 & 0.2 \\
\hline
\end{tabular}


Appendix E. Algal data from 1994-95 samplings in the North Umpqua River Basin-Continued

Table E3. Densities of algal taxa collected from 10 sites in the North Umpqua River Basin, Oregon, 1994-95-Continued

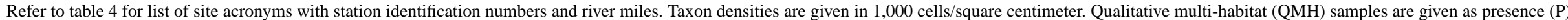

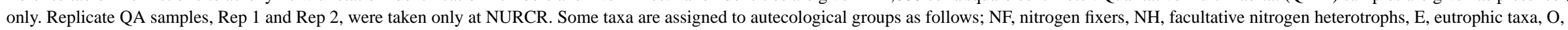

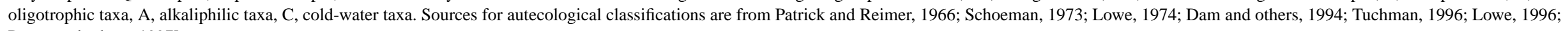
Porter and others, 1997]

Site and sampling date

\begin{tabular}{|c|c|c|c|c|c|c|c|c|c|c|c|c|c|c|c|c|c|}
\hline Algal taxa & Taxon code & Guild & $\begin{array}{l}\text { NURCR } \\
\text { 7/94OMH }\end{array}$ & $\begin{array}{l}\text { NURCR } \\
\text { 9/94OMH }\end{array}$ & $\begin{array}{l}\text { NURCR } \\
7 / 94\end{array}$ & $\begin{array}{l}\text { NURCR } \\
\text { 9/94 }\end{array}$ & $\begin{array}{c}\text { NURCR } \\
\text { 7/95Rep } 1\end{array}$ & $\begin{array}{c}\text { NURCR } \\
\text { 7/95Rep 2 }\end{array}$ & $\begin{array}{l}\text { NUSTM } \\
7 / 95\end{array}$ & $\begin{array}{l}\text { STEAM } \\
7 / 95\end{array}$ & $\begin{array}{c}\text { STEABB } \\
7 / 95\end{array}$ & $\begin{array}{c}\text { COPEG } \\
7 / 95\end{array}$ & $\begin{array}{l}\text { BSODA } \\
7 / 95\end{array}$ & $\begin{array}{l}\text { TOKET } \\
7 / 95\end{array}$ & $\begin{array}{l}\text { LEM1T } \\
7 / 95\end{array}$ & $\begin{array}{l}\text { INLET } \\
7 / 95\end{array}$ & $\begin{array}{l}\text { LAKEM } \\
\text { 7/95 }\end{array}$ \\
\hline \multicolumn{18}{|c|}{ Bacillariophyta (Diatoms)—Continued } \\
\hline Gomphonema ventricosum & GONEVENT & $\mathrm{O}$ & $\mathrm{P}$ & $\mathrm{P}$ & 0 & 0 & 0 & 0 & 0 & 0 & 0 & 0 & 0 & 0 & 48 & 0 & 0 \\
\hline Hannaea arcus & HANNARC & $\mathrm{C}$ & & & 0 & 3 & 0 & 0 & 0 & 0 & 0 & 0 & 0 & 72 & 24 & 20 & 0.5 \\
\hline Melosira varians & MELOVARI & NH,E,A & $\mathrm{P}$ & $\mathrm{P}$ & 0 & 0 & 0 & 0 & 0 & 0 & 0 & 0 & 6 & 336 & 48 & 10 & 0 \\
\hline Navicula anglica & NAVEANGL & & & & 0 & 0 & 0 & 0 & 0 & 0 & 0 & 0 & 0 & 0 & 0 & 10 & 0 \\
\hline Navicula cascadensis & NAVECASC & & & & 0 & 0 & 0 & 0 & 0 & 0 & 0 & 0 & 0 & 0 & 0 & 20 & 0 \\
\hline Navicula contenta biceps & NAVECObi & & & & 0 & 0 & 0 & 0 & 0 & 0 & 0 & 0 & 6 & 0 & 0 & 0 & 0 \\
\hline Navicula cryptocephala & NAVECRCE & NH,E,A & & & 0 & 0 & 0 & 0 & 0 & 0 & 0 & 0 & 65 & 24 & 48 & 30 & 0.5 \\
\hline Navicula decussis & NAVEDECU & & & & 0 & 0 & 0 & 1 & 0 & 0 & 0 & 0 & 0 & 0 & 0 & 0 & 0 \\
\hline Navicula exigua capitata & NAVEEXca & $\mathrm{E}, \mathrm{A}$ & & & 0 & 0 & 0 & 1 & 0 & 0 & 0 & 0 & 0 & 0 & 0 & 0 & 0 \\
\hline Navicula graciloides & NAVEGRAC & $\mathrm{E}, \mathrm{A}$ & & & 0 & 0 & 0 & 0 & 0 & 0 & 0 & 0 & 6 & 0 & 0 & 0 & 0 \\
\hline Navicula menisculus & NAVEMELU & $\mathrm{E}, \mathrm{A}$ & & & 0 & 0 & 0 & 0 & 0 & 0.4 & 0 & 0 & 0 & 0 & 0 & 0 & 0 \\
\hline Navicula minima & NAVEMINI & $\mathrm{NH}, \mathrm{E}, \mathrm{A}$ & & $\mathrm{P}$ & 5 & 0 & 0 & 0 & 0 & 0 & 3 & 0 & 6 & 0 & 24 & 30 & 0 \\
\hline Navicula mournei & NAVEMOUR & & & & 0 & 0 & 0 & 0 & 0 & 0 & 0 & 0 & 0 & 0 & 24 & 0 & 0 \\
\hline Navicula notha & NAVENOTA & & & & 0 & 0 & 0 & 1 & 0 & 0 & 0 & 0 & 0 & 0 & 0 & 0 & 0 \\
\hline Navicula pupula & NAVEPUPU & E & & $\mathrm{P}$ & 0 & 0 & 0 & 0 & 0 & 0 & 0 & 0 & 0 & 0 & 0 & 0 & 0 \\
\hline Navicula radiosa & NAVERADI & & $\mathrm{P}$ & & 2 & 0 & 0.4 & 0 & 0 & 0 & 0 & 0.2 & 0 & 0 & 0 & 10 & 0 \\
\hline Navicula reinhartii & NAVEREIN & $\mathrm{E}, \mathrm{A}$ & & & 0 & 0 & 0 & 0 & 0 & 0 & 0 & 0 & 0 & 0 & 0 & 10 & 0 \\
\hline Navicula rhynchocephala & NAVERHYN & $\mathrm{E}, \mathrm{A}$ & & $\mathrm{P}$ & 0 & 0 & 0 & 0 & 0 & 0 & 0 & 0 & 0 & 0 & 0 & 0 & 0 \\
\hline Navicula salinarum intermedia & NAVESAin & E & & & 0 & 0 & 0.4 & 1 & 0 & 1 & 0 & 1 & 0 & 0 & 0 & 0 & 0 \\
\hline Navicula schoenfeldii & NAVESCHO & & & & 0 & 7 & 0 & 2 & 0 & 0 & 0 & 0 & 0 & 0 & 0 & 0 & 0 \\
\hline Navicula sp. & NAVESPEC & & & & 0 & 0 & 0 & 0 & 0 & 0 & 0 & 0 & 0 & 0 & 24 & 10 & 0 \\
\hline Navicula sp. 1 ans hdsn & NAVESPE1A & & & & 0 & 14 & 3 & 3 & 0 & 0 & 0 & 0.4 & 0 & 0 & 0 & 0 & 0 \\
\hline Navicula viridula avenacea & NAVEVIav & $\mathrm{E}, \mathrm{A}$ & & & 0 & 0 & 1 & 0.2 & 0 & 0 & 0 & 0 & 0 & 0 & 0 & 0 & 0 \\
\hline Nitzschia amphibia & NITZAMPH & NH,E,A & & & 0 & 0 & 0 & 0 & 0 & 0 & 0 & 0 & 6 & 0 & 0 & 0 & 0 \\
\hline Nitzschia communis & NITZCONI & $\mathrm{NH}, \mathrm{E}, \mathrm{A}$ & & & 0 & 0 & 0 & 0 & 0 & 0 & 0 & 0 & 0 & 0 & 24 & 0 & 0 \\
\hline Nitzschia dissipata & NITZDISS & $\mathrm{E}, \mathrm{A}$ & & & 0 & 0 & 0 & 1 & 0 & 0 & 0 & 0 & 6 & 192 & 286 & 30 & 0 \\
\hline Nitzschia frustulum & NITZFRUS & NH,E,A & & & 341 & 715 & 42 & 31 & 0 & 6 & 5 & 3 & 42 & 24 & 382 & 20 & 0.5 \\
\hline Nitzschia frustulum perminuta & NITZFRpe & $\mathrm{O}$ & & & 37 & 79 & 7 & 1 & 0 & 0 & 0 & 0.2 & 0 & 0 & 0 & 0 & 0 \\
\hline
\end{tabular}


Appendix E. Algal data from 1994-95 samplings in the North Umpqua River Basin-Continued

Table E3. Densities of algal taxa collected from 10 sites in the North Umpqua River Basin, Oregon, 1994-95-Continued

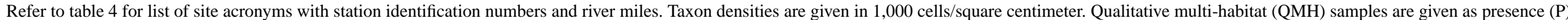

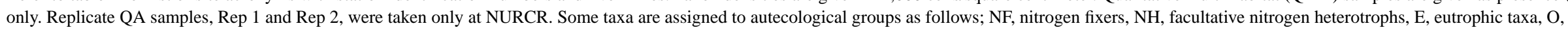

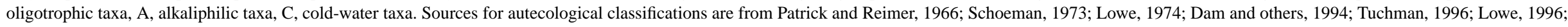
Porter and others, 1997]

\begin{tabular}{|c|c|c|c|c|c|c|c|c|c|c|c|c|c|c|c|c|c|}
\hline \multirow[b]{2}{*}{ Algal taxa } & \multirow[b]{2}{*}{ Taxon code } & \multirow[b]{2}{*}{ Guild } & \multicolumn{15}{|c|}{ Site and sampling date } \\
\hline & & & $\begin{array}{l}\text { NURCR } \\
\text { 7/94OMH }\end{array}$ & $\begin{array}{l}\text { NURCR } \\
\text { 9/94CMMH }\end{array}$ & $\begin{array}{l}\text { NURCR } \\
7 / 94\end{array}$ & $\begin{array}{l}\text { NURCR } \\
9 / 94\end{array}$ & $\begin{array}{c}\text { NURCR } \\
\text { 7/95Rep } 1\end{array}$ & $\begin{array}{c}\text { NURCR } \\
\text { 7/95Rep } 2\end{array}$ & $\begin{array}{l}\text { NUSTM } \\
7 / 95\end{array}$ & $\begin{array}{l}\text { STEAM } \\
7 / 95\end{array}$ & $\begin{array}{c}\text { STEABB } \\
7 / 95\end{array}$ & $\begin{array}{c}\text { COPEG } \\
7 / 95\end{array}$ & $\begin{array}{l}\text { BSODA } \\
\text { 7/95 }\end{array}$ & $\begin{array}{l}\text { TOKET } \\
7 / 95\end{array}$ & $\begin{array}{l}\text { LEM1T } \\
7 / 95\end{array}$ & $\begin{array}{l}\text { INLET } \\
7 / 95\end{array}$ & $\begin{array}{l}\text { LAKEM } \\
7 / 95\end{array}$ \\
\hline \multicolumn{18}{|c|}{ Bacillariophyta (Diatoms)—Continued } \\
\hline Nitzschia frustulum subsalina & NITZFRsu & & & & 14 & 0 & 0 & 0 & 0 & 0 & 0 & 0 & 0 & 0 & 0 & 0 & 0 \\
\hline Nitzschia linearis & NITZLINE & NH,E,A & & & 0 & 0 & 0 & 0 & 0 & 0 & 0 & 0 & 0 & 0 & 24 & 0 & 0 \\
\hline Nitzschia palea & NITZPALE & $\mathrm{NH}, \mathrm{E}$ & & & 0 & 7 & 0 & 0 & 0 & 0 & 0 & 0 & 0 & 0 & 0 & 0 & 0 \\
\hline Nitzschia paleacea & NITZPACE & $\mathrm{NH}, \mathrm{E}$ & $\mathrm{P}$ & $\mathrm{P}$ & 0 & 0 & 0 & 0 & 0 & 0 & 0 & 0 & 0 & 72 & 48 & 0 & 0 \\
\hline Nitzschia sp. & NITZSPEC & & & & 0 & 0 & 0 & 0 & 0 & 0 & 0 & 0 & 0 & 0 & 48 & 0 & 0 \\
\hline Nitzschia tropica & NITZSTROP & & & & 0 & 0 & 0 & 1 & 0 & 0 & 0 & 0.1 & 0 & 0 & 0 & 0 & 0 \\
\hline Nitzschia volcanica & NITZVOLC & & & & 0 & 0 & 0 & 0 & 0 & 0 & 3 & 0 & 0 & 0 & 0 & 0 & 0 \\
\hline $\begin{array}{l}\text { Pseudostaurosira } \\
\text { brevistriata }^{12}\end{array}$ & PSSTBREV & & & & 7 & 7 & 5 & 2 & 0 & 0 & 0 & 3 & 0 & 0 & 0 & 0 & 0.2 \\
\hline Reimeria sinuata & REIMSINU & E & & & 2 & & 8 & 2 & 0 & 0 & 0 & 0 & 6 & 0 & 0 & 0 & 0 \\
\hline Rhoicosphenia curvata $^{13}$ & RHSPCURV & E,A & $\mathrm{P}$ & $\mathrm{P}$ & 37 & 35 & 13 & 6 & 4 & 5 & 8 & 1 & 0 & 48 & 0 & 10 & 0.5 \\
\hline Rhopalodia gibba ${ }^{14}$ & RHOPGIBA & NF,E,A & & $\mathrm{P}$ & 0 & 7 & 0 & 1 & 0 & 2 & 11 & 0.2 & 0 & 0 & 0 & 0 & 0 \\
\hline Sellaphora pupula & SELAPUPU & & & & 0 & 0 & 0 & 0 & 0 & 0 & 0 & 0.1 & 0 & 0 & 0 & 0 & 0 \\
\hline Staurosirella pinnata ${ }^{15}$ & STSIPINN & E & & & 153 & 104 & 20 & 7 & 0 & 0 & 0 & 6 & 6 & 24 & 0 & 0 & 0.2 \\
\hline Synedra mazamaensis & SYNEMAZA & A & & & 0 & 10 & 0 & 0 & 0 & 0 & 3 & 0 & 6 & 0 & 0 & 0 & 0 \\
\hline Synedra minuscula & SYNEMINU & & & & 5 & 0 & 0 & 0 & 0 & 0 & 0 & 0 & 0 & 0 & 0 & 0 & 0 \\
\hline Synedra parasitica & SYNEPARA & & & & 0 & 0 & 0 & 0 & 0 & 0 & 0 & 0 & 0 & 0 & 0 & 10 & 0 \\
\hline Synedra radians & SYNERADI & E,A & & & 0 & 0 & 0 & 0 & 0 & 0 & 0 & 0 & 0 & 0 & 0 & 0 & 0.2 \\
\hline Synedra rumpens & SYNERUMP & E & & & 0 & 0 & 0.4 & 1 & 0 & 0 & 0 & 0.5 & 0 & 0 & 0 & 0 & 0.2 \\
\hline Synedra ulna & SYNEULNA & E,A & $\mathrm{P}$ & $\mathrm{P}$ & 37 & 62 & 4 & 5 & 0 & 23 & 26 & 0.5 & 0 & 72 & 0 & 0 & 0.5 \\
\hline \multicolumn{3}{|l|}{ Total density } & -- & -- & $7.2 \times 10^{3}$ & $5.0 \times 10^{3}$ & $3.3 \times 10^{3}$ & $2.2 \times 10^{3}$ & $1.8 \times 10^{2}$ & $6.0 \times 10^{3}$ & $2.8 \times 10^{2}$ & $1.7 \times 10^{3}$ & $6.0 \times 10^{2}$ & $2.8 \times 10^{3}$ & $2.5 \times 10^{2}$ & $7.6 \times 10^{2}$ & $2.5 \times 10^{1}$ \\
\hline \multicolumn{18}{|c|}{$\begin{array}{l}{ }^{1} \text { Includes Nostoc spongiiforme and Anabaena sp. } \\
2 \text { Includes Oscillitoria sp and Hydrocoleum brebissonii. } \\
3 \text { Includes Rivularia sp., Calothrix parietina, and Amphithrix janthina. } \\
{ }^{4} \text { Includes Kephyrion sp. and } \text { K. littorale. } \\
5 \text { Includes Achnanthidium lanceolata } \text { and A. lanceolatum dubium. } \\
{ }^{6} \text { Includes Cymbella mexicana and C. mexicana janischii. } \\
7 \text { Includes Epithemia sp., E. adnata, E. sorex, and E. turgida. } \\
{ }^{8} \text { Includes Fragilaria Canucina and } \text { F capucina mesopleta. }\end{array}$} \\
\hline
\end{tabular}


WATER-RESOURCES INVESTIGATIONS REPORT 98-4125

\section{SAMPLING SITES, NORTH UMPQUA RIVER BASIN, OREGON—PLATE 1}

Anderson, C.W., and Carpenter, K.D., 1998, Water quality and algal conditions in the North Umpqua River Basin, Oregon, 1992-95, and implications for resource management 